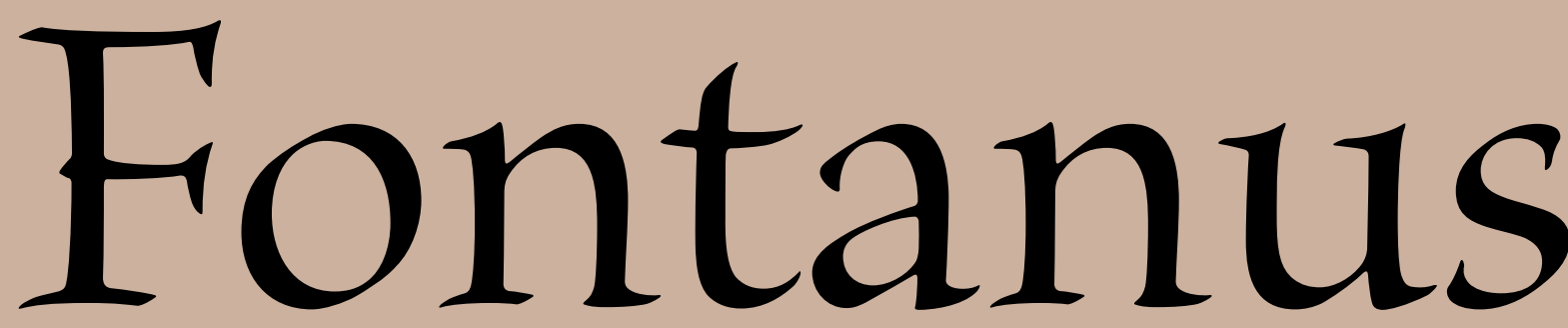

from the collections of

\title{
McGill University
}
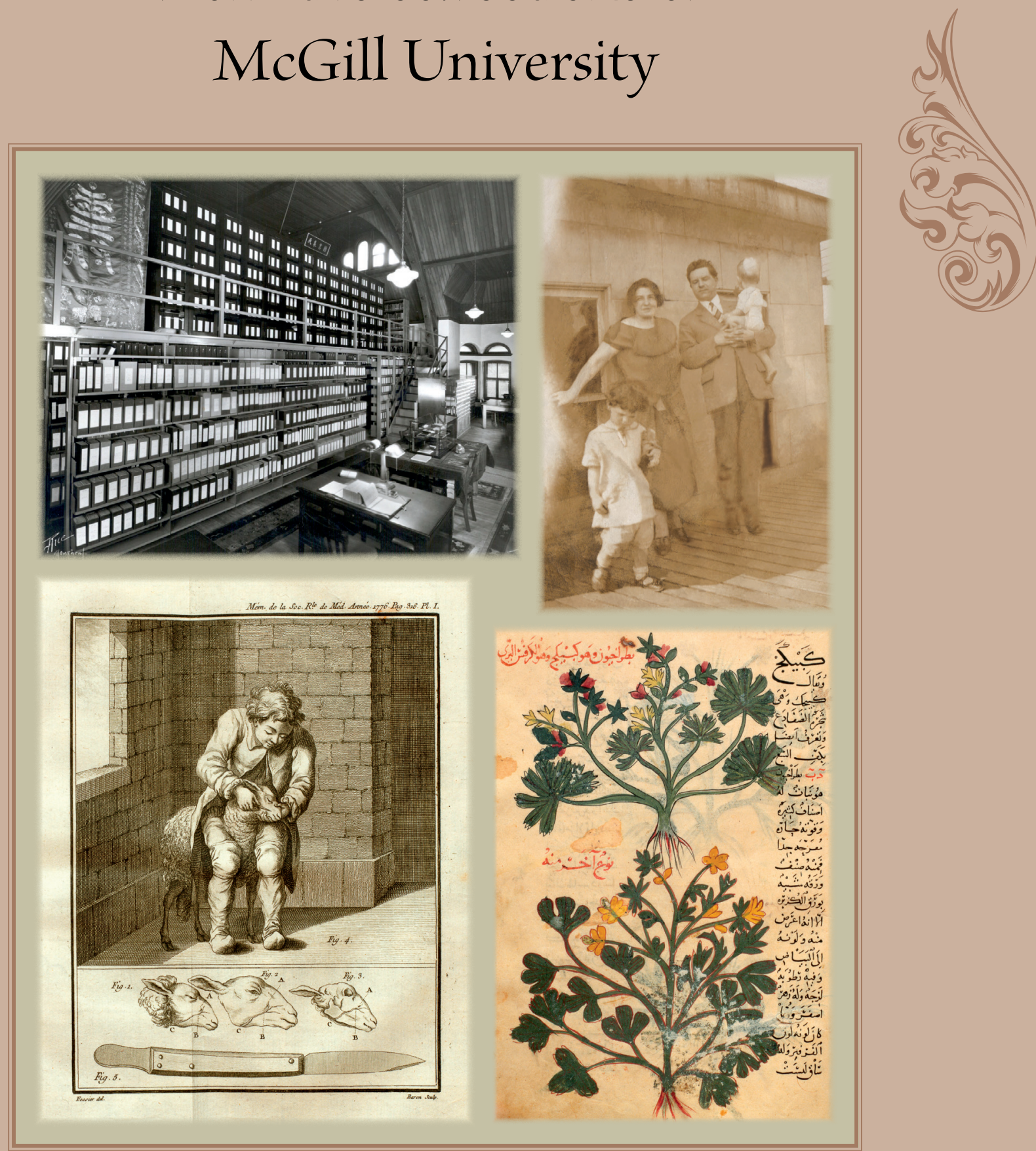

$.088 .088008^{\circ} 9^{\circ} \cdot 80^{\circ}$ 



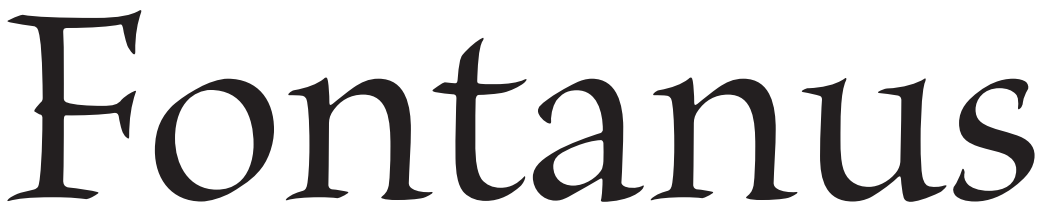

FROM THE COLLECTIONS OF MCGILL UNIVERSITY VOLUME XIII • 2013 


\section{Editors:}

Peter F. McNally

Robert H. Michel

\section{Editorial Committee:}

A. J. Hobbins

Christopher Lyons

Peter F. McNally, co-editor

Robert H. Michel, co-editor

Pamela Miller

Lonnie Weatherby

\section{Management Committee:}

C. Colleen Cook (chair)

Amy Buckland

Philip J. Cercone

Carman Miller

\section{Translations:}

Translations into French of the abstracts of the articles by William Fong, A.J. Hobbins, Peter F. McNally, Robert H. Michel, Sean Swanick, and Macy Zheng are by Marc Richard.

\section{Cover design and layout:}

Joel Natanblut

\section{Front cover:}

The cover reproduces images from articles by Daniel Hickey, Robert H. Michel, Sean Swanick, and Macy Zheng.

http://fontanus.mcgill.ca/

Copyright () 2013 McGill University Library

ISSN 0838-2026 


\section{Contents}

iv Call for Papers

v Dedication

vi Editorial

\section{ARTICLES}

3 The Volumes of the Royal Medical Society of France, 1776-1793:

a Window into Innovation, Patronage and Experimentation

Daniel Hickey

13 "The inconvenience of the present arrangement can only be realized by those who have to work under it": a History of the Legal Research Collections at McGill

A.J. Hobbins

25 Discovering a 'Hidden' Collection: Early Printed Books and Old Master Prints in the McGill

Library Collected by T.W. Mussen

Svetlana Kochkina

33 Régis Messac at McGill University, 1924-1929: Fact and Fiction

Robert H. Michel

69 Principal Sir Arthur Currie and the Department of Chinese Studies at McGill

Macy Zheng

81 J.W. McConnell and the Chancellorship of McGill University, 1942-3

William Fong

95 Islamic Studies Library: Growth and Evolution

Sean Swanick

105 McGill University and Quebec City in the 1960s

Peter F. McNally

117 A Brief History of MUNASA: McGill Non-Academic Staff Association

Gordon Burr

NOTES AND COMMENTS

125 Frank Scott's University of Dystopia, 1924

Robert H. Michel

127 Buildings and Construction at McGill, 1970-2002

Peter F. McNally

131 "Easy, debonair and brisk": Maxime Ingres at McGill, 1895-1900

Robert H. Michel

135 Contributors

136 Guidelines for Authors

137 Fontanus Publications 


\section{Call for Papers}

That do Arabic manuscripts, John Humphrey, Sir Arthur Currie, Hugh McLennan, Peter Redpath, Ernest Rutherford, W and James McGill have in common? They have all been the subject of scholarly articles in Fontanus based on McGill University's many fine collections. Detailed descriptions of the collections may be accessed from the McGill Historical Collections web site: http://www.mcgill.ca/historicalcollections/

The editors of Fontanus are currently seeking articles as well as briefer notes and comments, in English or French, for Volume XIV.

Fontanus is an annual publication devoted to scholarly research making substantial use of McGill University collections. The term "collections" is interpreted in the broadest sense to include all forms of evidence: books, archives, clay tablets, electronic records, specimens, artifacts, costumes, photographs, films and buildings.

For more information regarding the submission of manuscripts, please see the Guidelines for Authors on page 134 in this issue.

Editors, Fontanus

c/o Dean of Libraries

McLennan Library Building

3459 Mctavish Street

Montreal, QC, Canada H3A 1Y1

http://fontanus.mcgill.ca/

fontanus.library@mcgill.ca 


\section{Dedication}

$T$ his volume is dedicated to the memory of Dr. Stanley Frost (February 17, 1913-July 25, 2013),

1 who was born in England before World War I, and passed away in Montreal a few months after celebrating his 100th birthday. After coming to McGill in 1956, he served successively as Professor of Old Testament Studies and Dean, Faculty of Divinity-subsequently Faculty of Religious Studies - Dean of Graduate Studies and Research, and Vice-Principal Administration and Professional Faculties. Notable publications of this era were:

- The Beginning of the Promise, Eight Lectures on Genesis (1960)

-Patriarchs and Prophets (1963)

-Standing and Understanding: a Reappraisal of the Christian Faith (1969).

From 1975 to 2003 he served as the first Director of the History of McGill Project, publishing among other things:

-McGill University: for the Advancement of Learning. vol. I, 1801-1895. 1980

-McGill University: for the Advancement of Learning. vol. II, 1895-1971. 1984

- The Man in the Ivory Tower: F. Cyril James of McGill. 1991

-James McGill of Montreal. 1995

In later years, Dr. Frost published annual volumes of his poetry for friends and associates. Many of the poems were anthologized in:

-Autumn Harvest, Selected Poems. 2002 "Fontanus Monograph"

He was particularly concerned with libraries. From 1963 to 1970 he was Chair of the University Libraries Committee. He was also a member of the first Editorial Committee for Fontanus: from the Collections of McGill University, in which he published the following articles:

-“The Redpath Hall: the Portraits," v. 6 (1993) p. 85-96.

-“James McGill and the War of 1812," v. 7 (1994) p. 41-52.

- “Sir William Macdonald: an Unfinished Portrait," with Robert Michel, v. 8 (1995) p. 58-81.

-“Much Given to Reading:' a Literary Footnote on James McGill," v. 9 (1996) p. 9-15. 


\section{Editorial}

$\mathrm{T}$ his thirteenth volume of Fontanus presents nine articles and three briefer "Notes and Comments" based on a wide range of McGill University collections. The McGill University Archives provided the main sources for six of the articles; the other articles mined holdings of the McGill Library's Division of Rare Books and Special Collections, the Osler Library of the History of Medicine and the Islamic Studies Library. The Articles and Notes fall into three categories: 1) the history and development of individual McGill libraries and collections; 2) biographical and literary studies of individuals who played a role at McGill; and 3) aspects of McGill's institutional history. While connected to McGill, the articles illuminate the gamut of activities common to most universities, including the role of benefactors; unique, accidentally acquired yet valuable collections; and not altogether happy professors. Not surprisingly, these categories can overlap. For instance, the article by Macy Zheng traces not only McGill's early attempt to develop Chinese studies but a prescient, little known side of Sir Arthur Currie.

Our understanding of the history of McGill's libraries is extended in two articles. John Hobbins recounts the early accomplishments and trials of the Law Faculty Library. Sean Swanick treats the development of the Islamic Studies Library, established in the 1950s, as the West was renewing its vital interest in Islam. Individual collections also are examined by two articles. Using Osler Library holdings, Daniel Hickey studies late eighteenth century reports of the Royal Medical Society of France to examine emerging developments in French medical practice. Library historians have long been fascinated by how private collections are formed and sometimes dispersed or "hidden" when submerged in large libraries: Svetlana Kochkina resurrects and closely analyses the collection of rare books and masters' prints assembled by Thomas Mussen.

Other articles deal with studies of individuals who played a role at McGill and with various aspects of McGill's history. William Fong, author of J.W. McConnell: Financier, Philanthropist, Patriot (McGill-Queen's, 2008), offers an expanded, detailed account of this munificent benefactor and McGill's Board of Governors' politics regarding the Chancellorship in 1942-3. Robert Michel writes on the McGill careers of two accomplished, unconventional and dissatisfied French teachers. The first is Régis Messac (1924-1929) who wrote a satirical novel based on his McGill adventures. The second is Maxime Ingres (1895-1900), who is covered in a Note-as is Frank Scott (BCL 1927) and his foray into university satire. Peter McNally, historian of McGill, provides a comprehensive analysis of the challenges facing the University in the turbulent $1960 \mathrm{~s}$ as well as a Note on McGill's construction of buildings, 1970-2002. Gordon Burr writes a history of a uniquely McGill organization, the McGill NonAcademic Staff Association (MUNASA), which has evolved through several changes since being founded in 1972.

In sum, this volume treats McGill's interface with Chinese, Islamic and French studies, library and collections development, intriguing people, and internal and external politics and administration. We are confident that the issues, individuals and stories you meet here will be of intellectual, political and social interest to readers everywhere.

The Editors 
Articles 



\title{
The Volumes of the Royal Medical Society of France, 1776-1793: a Window into Innovation, Patronage and Experimentation
}

\section{by Daniel Hickey}

\begin{abstract}
In 1776, Doctors Vicq d'Azyr and Joseph de Lassone founded the Royal Medical Society of France and that same year the new Society began publishing an annual volume of news of medical interest, obituaries on the deaths of outstanding doctors and surgeons, articles on new medicine and drugs, on new operations as well as reflecting on the causes of different diseases and illnesses. Between 1776 and 1793 , ten of these volumes were published under the title Histoire de la Société Royale de Médecine: histoire et mémoires. The Osler Library of the History of Medicine possesses four of them. Breaking with the tradition of Galen and with the diagnoses based on bookish knowledge, the members of this group favoured experimentation, the dissection of corpses and the close observation of the symptoms of the sick and the dying. This article looks at two aspects of their work: first it examines the goals and the structures of the Society that published the volumes and second, it analyses the organization and the types of articles published in the annual volumes.
\end{abstract}

\section{RESUMÉ}

Les médecins Vicq d’Azyr et Joseph de Lassone ont fondé la Société royale de médecine en 1776 et aussitôt la nouvelle société a commencé à organiser la publication annuelle d'un volume de nouvelles d'intérêt médicales. Il devrait comporter les avis de décès des médecins et chirurgiens de renom, les articles sur des médicaments et drogues qui venaient d’être mis sur le marché, les interventions particulièrement innovatrices et les réflexions sur les causes de différentes maladies et épidémies. Entre 1776 et 1793, dix de ces volumes sont apparus sous le titre, Histoire de la Société Royale de Médecine: histoire et mémoires. La bibliothèque Osler de l'histoire de médecine détient quatre de ces volumes. Les articles des membres de ce groupe rompent avec la tradition de Galien et avec les diagnostics fondés sur les connaissances livresques. Ils favorisent l'expérimentation, la dissection des cadavres et l'observation des symptômes présentés par les maladies et les mourantes. Cet article étudie deux aspects de ces travaux: d'abord, il décrit les buts et les structures de la Société elle-même et second, il analyse l'organisation et les types d'articles publiés dans les volumes annuels.

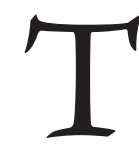
he Osler Library of Medical History is perhaps the best example of a repository of rare and valuable sources in the field of the history of medicine for Canada and the United Kingdom, but it also has strong resources for France. Several years ago, I came across several volumes of the invaluable Histoire de la Société Royale de Médecine: histoire et mémoires, an annual publication of the late $18^{\text {th }}$ century Royal Medical Society of France, a learned society created by several doctors and public health specialists. The Osler Library purchased its four volumes of the Histoire de la Société Royale de Médecine: histoire et mémoires in 1981 from the Librairie Alain Brieux in Paris. ${ }^{1}$ From its very beginning the Royal Medical Society that published the volumes had a triple objective. First, it sought to renew the practice and teaching of medicine by recruiting new, young medical men and researchers. Second, it wanted to "professionalize" the medical expertise of practicing physicians and surgeons by providing them with information on new operations, experimentations and medication. Finally, it worked to maintain and to reinforce its links to the royal court and to the lucrative contracts it received through favouritism and patronage. This article will concentrate on the Society and its annual volumes in two sections. Initially, it will analyze the origins of the Society and its founding members who organized and published the volumes. Secondly, it will look at the contents of the volumes, trying to show their links to the three objectives the directors sought to promote.

\section{THE ORIGINS AND THE FOUNDERS OF THE SOCIETY}

Initially, the Royal Medical Society was formed by a number of medical men and health specialists who had served together to combat a major outbreak of epizooty, or cattle plague in 1774-75. Controlleur-général Turgot appointed Vicq d'Azyr, the future head of the Royal Medical Society, to deal with the epidemic. Vicq d'Azyr decided to go well beyond the traditional methods of segregating sick animals in times of such an epidemic. He set up sanitary cordons to divide the affected area into different categories: disease-free 
areas were to impose precautionary hygienic measures, the threatened areas were submitted to a more drastic regime of drugs and disinfectants, and the center of the outbreak was to be cordoned off and the sick animals were to be slaughtered and buried in quicklime with the government offering token remuneration to the farmers. ${ }^{2}$ The royal court saw the work of Vicq d'Azyr and his colleagues in dealing with this outbreak as a model of the application of new sanitary practices.

After dealing with the 1774 outbreak, Vicq d'Azyr together with his colleague Joseph de Lassone, set out to found the new Royal Medical Society. They used many of the contacts they had made during the 1774-75 epidemic to establish the Society in 1776 and to obtain a charter for the group in 1778. The Society they set up met twice a week to listen to and to debate papers and reports in the field of medicine and public health presented by its members and correspondents. In 1776, the first year of its activities, the Society began preparing the first of the volumes found in the Osler Library. The eventual collection included the papers presented at Society meetings, obituaries, research notes, memoirs and reports on the organization's activities. The annual volumes were actually published a year or two after their compilation such that the 1776 volume was published in 1779 . In all, the Royal Society published 10 of these volumes, the last of which appeared in 1789, the year that marked the beginning of the French Revolution. The Society was broken up in 1793, the year Louis XVI was sent to the guillotine.

Among the goals of this organization were the promotion of new teaching methods and new ways to practice medicine. According to the American historian Caroline Hannaway, the program set out by the men behind the Society would eventually bring them into conflict with the directors of the Paris Faculty of Medicine, who accused them of trying to appropriate too much power over the teaching and practice of medicine in France. ${ }^{3}$ However, the Society has been credited with playing a major role in the eventual establishment of the Paris Clinic. ${ }^{4}$ The Paris Clinic represented a major change in the perception and practice of medicine in France. Based upon empiric investigation, it sought to brush aside the traditional "bookish" medical knowledge derived from Galen or Paracelsus in which doctors used their reading and personal judgement to diagnose their patients one by one based on the descriptions of their pains and problems. Instead, with the French Revolution and the creation of the École national de medicine in 1794, medical authorities adopted new techniques of anatomic-clinical investigation. Doctors and surgeons sought to use the hospitals as laboratories to observe the sick and to teach their students. To confirm their diagnoses, they used their experience in dissecting corpses, their close observations of the symptoms of their sick patients and their accumulated medical statistics. A whole new cohort of doctors and surgeons practiced this new type of medicine, among them, Marie-François Bichat (1771-1802), JeanNicolas Corvisart (1755-1821), Pierre Louis (1781-1826) and René Théophile Laennec (1781-1826). ${ }^{5}$ One of the bases of this new scientific medicine was the abandoning of the long tradition of separating the work and training of doctors and surgeons. They were both incorporated into the new École national de medicine and into the hospital structure. In many ways, this new type of medicine followed closely a document that Vicq d'Azyr, secrétaire perpétuel of the Royal Medical Society, had submitted to the National Assembly in 1790. It was the draft of a law to govern the practice of medicine in France and it proposed the convergence of medical and surgical practice and training, the extension of hands-on experience for students through the examination of the sick and the dying as well as the dissection of cadavers. The new programme also proposed to set up an Academy of medicine to promote the advancement of medical science. ${ }^{6}$ In 1794 the framework of several of these proposals was effectively incorporated into the charter of the École national de santé, one of the principal building blocks of the Paris Clinic.

As with all types of innovation, however, the Royal Society was a mix of old and new. Its members were torn between their tendency as children of the Enlightenment to turn the page on old methods and at the same time their desire to remain attached to the benefits they derived from the old society, from the patronage of the royal court and the Crown and from the sponsored "research" and the contracts distributed through favouritism. Vicq d'Azyr, originally from Normandy, was a researcher in anatomy at the Paris Faculty of Medicine and he held a position as consulting physician to the King's brother, the count of Artois. Even more important was Joseph de Lassone, principal physician to Queen Marie Antoinette. Through his position he maintained close ties to the royal court. Lassone co-presided over the Society with Joseph Lieutaud, Dean of the Paris Medical Faculty. However, the role of Lieutaud was mainly symbolic. Caroline Hannaway found that he had never attended a meeting of the group and that he died in 1780. In fact, after his passing, the Paris Faculty of Medicine became one of the principal opponents of the Royal Society and to its attempts to renew the teaching and practice of medicine in France.

Who actually made up this new Society? According to the patent letters of 1778 , the general assembly was to be composed of thirty ordinary associates (associés ordinaires) who were to elect the president and vice-president. They were also to name one of their members as secrétaire perpétuel, although it was noted in the patent letters that they "had named and confirmed Sieur Vicq d'Azyr to continue to exercise that function." And he held the position right up to the dissolution of the Society. In addition, the patent letters specified that twenty of the thirty associates were to be medical doctors, residents of Paris and members of the Paris Faculty of Medicine. The other ten were to be chosen without restriction by the associés. In addition to the ordinary associates, the document noted that the Society was to be made up of twelve associés libres, residents of Paris, sixty 
associés regnicoles coming from the French provinces and another sixty associés étrangers coming from outside France. ${ }^{8}$

At the same time that this structure appears relatively transparent and open to new, younger members, there were clauses that allowed the directors to maintain control over the organization, clauses that were regularly cited by critics like the Faculty of Medicine. An example of these clauses is article $\mathrm{V}$ stipulating that:

The Society will proceed by vote to elect the secrétaire perpétuel, the associés ordinaries, libres, regnicoles and étrangers: \& it will present the Society with the person who appears most apt to fill the vacant position; preferring, however, that the positions of the associés be and remain filled by those who presently occupy them: knowing their zeal, experience and capacity, we [the directors] have confirmed them in their positions... ${ }^{9}$

It is clear that the positions of Lassone and Vicq d'Azyr were not to be surrendered and that they surrounded themselves with friends and collaborators from the 1774 work on the epizootic outbreak.

The first six associés, Antoine Laurent de Jussieu, Claude Caille, Jean de Lalouette, Dieudonné Jeanroi, Michel Augustin Thouret and Jean Jacques Paulet were all friends, close to Vicq d'Azyr. The first three were young medical doctors who had just been named regents of the Paris Faculty of Medicine. Jeanroi and Thouret had almost finished their medical degrees and Paulet was a medical doctor from Montpellier who had worked on the 1774 epidemic. The five doctors added in July 1776 were more experienced: Michel Bouvart, Pierre Poissonier and his brother Antoine, Charles Lorry and Pierre Maloet all had important medical practices in Paris. With their nominations the directors appear to have tried to give added credibility to the Society. Other important medical men appeared in subsequent lists although their functions had not been among those named in the patent letters. Antoine Fourcroy, a protégé of Vicq d'Azyr and a student at the Faculty of Medicine, held the position of secretary. Another category absent from the patent letters, the associés adjoints, appeared in October 1776. Among the new men named in that category were Pierre Mauduyt de la Varenne, a specialist on electromagnetic applications in medicine, Charles Andry, a researcher on effects of rage, Charles Saillant on epilepsy, Henri Tessier on botany, and Jean Colombier, one of the principal architects of hospital policy and administration.

Clearly, this core of researchers, administrators and medical men was built up around the friends and associates of Lassone and especially of Vicq d'Azyr. They were generally engaged in experimental research and uncontaminated by what they termed the "old methods" of the Faculty of Medicine. Other supporters of the movement, politicians and royal officials surrounded these men and partisans of the Enlightenment were added as associés libres. Among them there was the Duc de la Rochefoucault, one of the leading promoters of enlightenment research; Jacques Necker, the Minister of Finance; the Count of Vergennes, a Minister and former Secretary of State; Poulletier de la Salle, a Maitre de requêtes; Montigny, the President des Treasurers of France. All of these men provided key support for the Society within the inner circles of the royal government. In the category of associés étrangers, the group also sought to increase its credibility and prestige. Among the foreigners selected, were Benjamin Franklin from the United States, Dr Tissot from Lausanne, Switzerland and Dr William Hunter from England.

\section{THE ORGANIZATION AND CONTENTS OF THE VOLUMES}

Right from the first volumes of the Histoire de la Société Royale de Médecine: histoire et mémoires, the Society had a clear objective of renewing the practice and teaching of medicine as can be seen by the selection and recruitment of young medical men and researchers. At the same time, it sought to remain attached to the favoritism of the Court and to the contracts accorded through favoritism and patronage. These two directions can be observed in the research projects undertaken by the Society, in the reports read before the members at the regular meetings, in the prizes regularly awarded to young researchers and in the approval of new medications and sources of mineral water.

From the first volume, Vicq d'Azyr, who was responsible for the publication, announced the twelve different sections to be treated in each tome (see Table 1). The treatment of these themes was to be divided it into two sections-Histoire and Mémoires. In the first of these sections he published news articles, death notices, comments on published works, meteorological observations and short articles and notices concerning forthcoming publications. The second section of each volume was to treat the same types of subjects through much longer research reports treating the different stages of each project, the experiments conducted and the results obtained. The length of these articles frequently attained a hundred pages. The Society also sponsored a competition for medical researchers who were asked to read their papers before the Society. The directors of the organization proposed questions to its members, associates and correspondents who delivered papers on the suggested themes. The best papers received prizes varying from 300 to 600 livres and they were to be published in the upcoming volume.

The articles, notices and projects published each year provide us with a window from which to observe the objectives of the Society in each of its areas of expertise. I have selected four of these areas for in-depth examination. 


\section{Reinforcing the perception of the medical profession}

First and foremost among the objectives of the Society was the desire to reiterate and to reinforce the common values that should be shared within the medical profession. Vicq d'Azyr used the obituaries of deceased medical men to promote the professionalization of his colleagues. He described in hagiographical terms the lives of those he judged to have been outstanding medical men and proposed them as role models for their colleagues. The French historian, Daniel Roche, has studied a corpus of 56 of these obituaries: in 45 cases the deceased were medical doctors, in 3 cases doctors of surgery, in 3 other cases simple surgeons and in the remaining three cases apothecaries or chemists. ${ }^{10}$ In several of his long eulogies (25-30 pages), Vicq d'Azyr tried to build up an idealistic image of the physician of the Enlightenment and whenever he could, he attributed to his deceased colleagues the qualities that he associated with the modern medical man. Education was consistently valorized-the colleges they frequented were indicated for 37 of the 56 men and for 45 of them he noted the University attended. ${ }^{11}$ In the course of their training, he underlined the importance of clinical practice and the integration of other disciplines in their studies (physics, chemistry and the humanities). In the case of Linné, it was noted that as a teacher, he integrated physics lessons into the medical courses he taught at Uppsala and in the obituary for Haller, the note emphasized that he had taught at Tübingen, Leyde and Bâle where the curriculum reflected a "modern" approach. ${ }^{12}$ Hospital teaching was particularly favored in these eulogies and in the case of the Irish doctor MacBride, Vicq d'Azyr noted the importance of practice and observation in the formation of a physician,

"...it was clearly in the hospices where a wise administration cares for the poor and suffering that young doctors and surgeons can find useful lessons... It is there that one can learn to read in the eyes, in the facial traits, in the gestures, in the comportment of the sick and to distinguish those signs that the observer can see without being able to describe them, signs that cannot be found in books, and which it is so important not to mistake."13

Other issues of the time were treated in the obituaries. Vicq d'Azyr emphasized whenever possible the denunciations of charlatans and empirical "doctors" by the deceased. Writing about Dr Girod, inspector of public health in FrancheComté, he noted that Girod, "scared and dispersed the hoards of inept charlatans who...flood the countryside and sell hope and poison to the gullible peasant." ${ }^{\prime 14}$ Altogether, he found similar denunciations for 12 of the 53 deceased colleagues. Finally, on the question of the devotion of these men, Vicq d'Azyr contended that three-quarters of them died of "fatigue" or of the "dangers" linked to their profession. Writing about

\section{Table 1. The proposed divisions of each volume of Histoire de la Société Royale}

1. The activities of the Society during the year.

Reports on the proceedings of the two public sessions.

Résumés of the conferences held.

Prizes accorded for the best presentations.

Grants received for applied research, such as the origins of different epidemics.

Obituaries of members who died during the year.

Observations and reviews of books, reports and publications submitted by members.

All changes in the statutes and regulations of the Society.

2. Weather observations for the year compiled from reports submitted by members and correspondents.

3. Descriptions of the topography of different regions, cities, towns and villages with details concerning the impact of various factors on health of inhabitants.

4\&5. Reports on human or animal epidemics in different regions, towns, prisons or hospitals.

6. Epizootic illnesses.

7. Analyses of the nature or treatments of acute or chronic illnesses.

8. Contagious illnesses.

9. Discussions of anatomy and of illnesses identified from dissecting cadavers.

10. Biochemical medicine: the analysis of new medicine and mineral water sources.

11. Botany and natural history.

12. The study of physics applied to medical treatments. 
Dr Maret of Burgundy, he noted that the doctor had left for Fresne-Saint-Mamès to treat several patients suffering from an epidemic fever and upon his arrival in the village he himself came down with the fever, however, according to Vicq d'Azyr, Maret continued to care for his patients, "a contagious doctor who visited his patients and tried to bring them back to life even as he himself was dying."

\section{Demonstrating the research and innovation of the profession}

The second major objective of the Society was to demonstrate the serious research and innovation of the modern medical profession. The men associated with the Society sought to turn the page on past medical practices as was evident in the formal presentation of their papers in the annual volumes. Methodology was particularly important and each paper read at their meetings contained a long description of the research methods used. Among others, Charles Lorry applied this approach in his paper on human obesity, its effects on the body, its vices and the diseases it could cause. Delivering this research before his colleagues on 7 September 1776, he began by setting out his approach,

"Let us leave to the professors who lecture their disciples on the task of examining and refuting the hypotheses that have created public opinion from Hippocrates to today. For us, we have the obligation to examine and to learn by observing... It is within this context that I will expose what my observations over a period of several years have taught me concerning the effects of fat in the human body as a secondary cause of morbidity, either directly because of the mass of fat or indirectly because of the effects it can produce on other humours..." ${ }^{16}$

The pages of the Histoire de la Société royale are full of observations and research papers that follow the methods explained by Lorry. Each of the volumes contained sections in which doctors, surgeons and veterinarians explained in detail the different steps they had taken in trying to cure rare physical disorders, proposing new experimental treatments and illustrating new types of procedures. As Brockliss and Jones have noted, the Society opened the door to experimentation with new empirical approaches for both humans and animals. ${ }^{17}$ The cases included in these sections extended from major surgeries to items like the veterinary Daubenton's remedies for treating sheep disorders, including recommendations on the best places to carry out bloodletting on sheep, suggesting bleeding the animal below the cheek bone (see Illustration 1). ${ }^{18}$ Among other contributions is an article by Dr Hannequin, a surgeon in Charleville, on a Caesarian section that he performed "with success" on a 28 year old woman. His test follows the methodology prescribed by the Society as he explains step by step the evolution of his patient from 31 August, the date of his intervention through the healing process up to 24 September. Describing the operation, Hannequin noted that he "made an incision eight inches long with his scalpel on the right-hand side of the lower stomach. The peritoneum was opened with the aid of a crenulated scalpel which was also used to open the uterus in which a seven inch incision was made...revealing the [dead] child who was extracted from the womb, a very large male baby." ${ }^{19}$ Hannequin's daily observations note the vital signs of the patient during her recovery, her pains and the healing of the wound. It should be noted that the "success" of the interventions should be understood in the context of the period, an intervention made without anesthesia and generally made only in the case of extracting dead babies.

Inoculation was another subject of predilection for the members of the Society and Dr Girod, who was eulogized by Vicq d'Azyr in the 1786 volume, had contributed an article on the success of the inoculation campaign against smallpox in Franche-Comté. It appeared in the 1780 volume that was published in 1785. Girod noted that in the village of Millau, Pelet, an "enlightened" doctor, carried out his first inoculation on an orphan girl and the success of the intervention led to the inoculation of 229 other villagers between 20 March and 20 June and "none of them died." ${ }^{20}$ Such descriptions of new prophylactic methods and techniques were legion in the volumes of the Histoire de la Société royale. Among other interventions, they described the actions taken against aneurysms, scurvy, rage, ergotism, military fever, dropsy and kidney stones.

\section{Analyzing the influence of climate and topography}

The Royal Medical Society was born as an offshoot of the 1774 epizootic epidemic and the Crown obviously wanted the group to continue its research into the possible causes of such outbreaks. From the time of Hippocrates it was believed that polluted air led to contagion and it was only with the coming of bacteriological studies and particularly the work of Pasteur that the development of the study of internal organisms like bacteria, micro-organisms and viruses changed the direction of medical studies. Medicine at the time of the Enlightenment still stuck to the theory that outside forces like polluted air, humidity and climate caused sickness and epidemics. ${ }^{21}$ To study these phenomena, the volumes of Histoire de la Société royale contained long and detailed data on climate and topography, seeing them as a cause of sickness and epidemics.

In the second section of each volume, Father Cotte, an associe regnicole, published the meteorological observations conscientiously submitted by correspondents scattered throughout France: daily indications of temperature, barometer readings, periods of sunshine, humidity, rainfall, wind direction and velocity. Alongside these tables, the correspondents indicated the five or six sicknesses most 
Mém. de la Soc. Rle de Méd. Arriée. 2776 . Pag. 326. Pl. I.

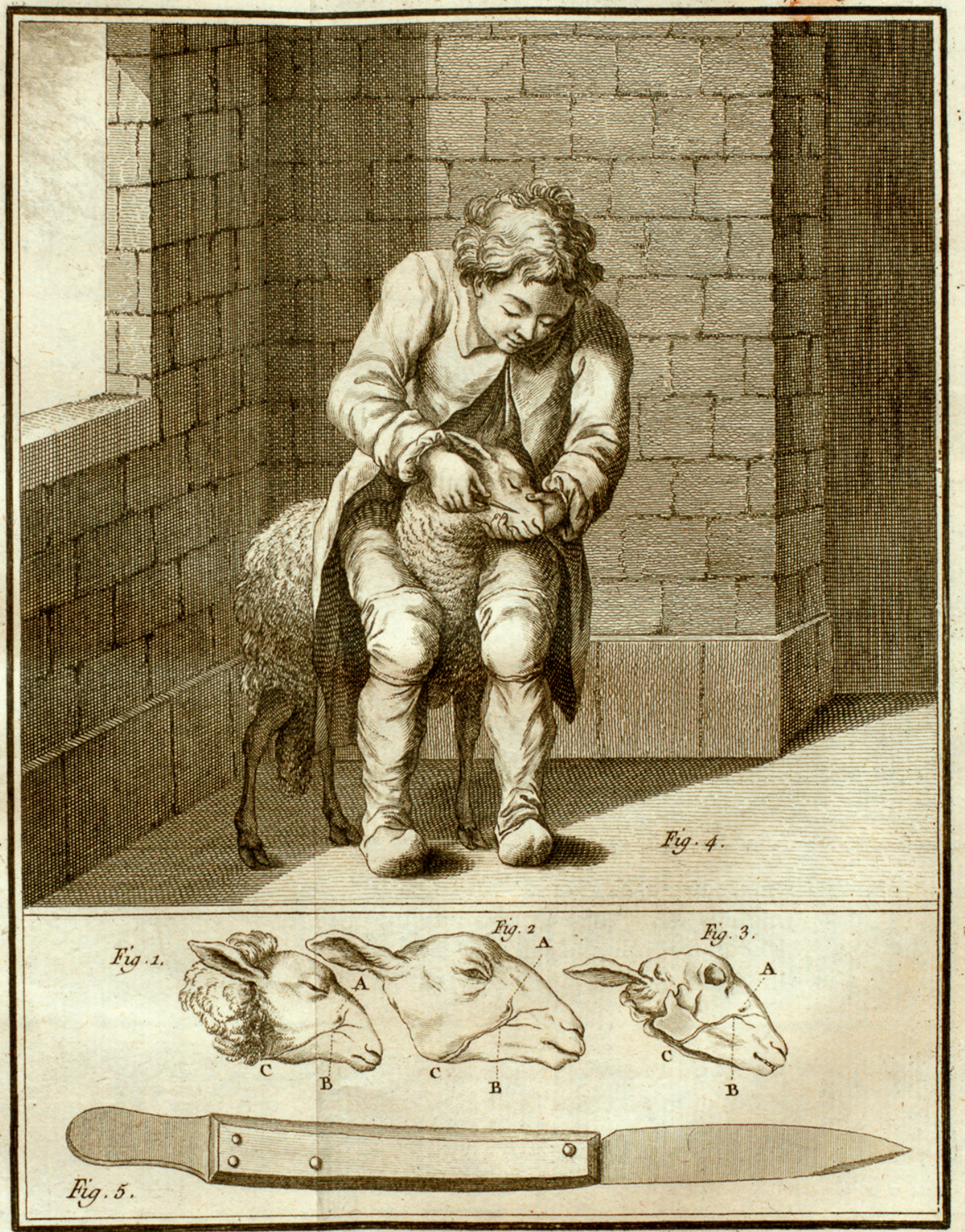

Fossier del.

Baron Sculp.

Illustration 1. Remedies for treating sheep disorders. Recommendations of places to carry out blood-letting [Histoire de la Société royale de médecine : histoire et mémoires, 1776. Paris : Philippe-Denis Pierres, 1779, 316-17]

Reproduced by permission of the Osler Library of the History of Medicine, McGill University 
frequently treated during the month along with notes explaining how these illnesses first appeared, their symptoms, their progression, the seriousness of their impact, the treatments given to patients and their morbidity. Often the correspondents illustrated their observations with concrete cases.

The third section of each volume continued on this theme with detailed micro-studies on selected towns and regions where the authors elaborated on the interaction between sickness and climate, topography, demographic density, diet and agricultural production. This section was obviously a follow-up on the type of study that Vicq d'Azyr had prepared in his 1774-75 work on the epizootic epidemic in Languedoc and it constituted an extension of Abbé Cotte's tables. It was clear that the directors of the Society felt that such studies responded to societal needs and at the same time they made a favorable impression on Crown officials. This is corroborated in a note in volume IV that the government and several of the members of the Society had contributed 4,000 livres to encourage such work. ${ }^{22}$

Here too, the Society's correspondents submitted articles that reflected the beliefs of the pre-Pastorian period to combat epidemics. One of their foreign associates Antoine Ribeiro Sanchès, who had been chief physician to the Empress of Russia, contributed an article on Russian steam baths as a means of combating smallpox, pleurisy, chest and kidney disorders. He even proposed a blueprint of what he considered to be the ideal plan for building a steam bath (see Illustration 2). ${ }^{23}$

This concentration on epidemics can also be seen in the subjects studied in the essay competitions held by the Society. The directors of the organization often proposed questions relating to the cause of epidemics. In 1776, the first year of its existence, the judges asked for papers establishing "...the relation between epidemic illnesses and other concurrent illnesses that struck at the same time and place." Seeing that the papers submitted were not up to the standards of the Society, the judges turned them all down and they repeated the question in a subsequent competition. Finally, in 1781, they accorded a prize of 600 livres to Dr Raymond of Marseilles for his text on the subject, read before the group at their March 6 meeting. In his work on the activities of the Society, the late French historian, Jean-Pierre Peter saw the organization's research in linking illness and epidemics to the environment and to the lack of municipal and regional improvements in health and sanitation as one of the major contributions to the medicalisation of French society. ${ }^{24}$

\section{Approving new drugs and mineral water sources}

Just as with their work on climate and topography, the dealings of the Society with new drugs and mineral water sources responded to the preoccupation of both the public and the Crown with these questions. During the $18^{\text {th }}$ century, there was a marked increase in the popularity of both new drugs and new mineral water sources. However, many of these remedies were considered to be precisely the type of quack medicine that the Society associated with "Charletanism". In the interest of public health, the Society lobbied the Crown to obtain the right to inspect and to approve the new drugs to be sold and new the mineral water to be commercialized in the Kingdom. This was the most controversial of the group's activities. It was a very profitable initiative on the part of the Society, but it led the group into considerable difficulty trying to maneuver between the marketplace, its patrons and its clients. According to detractors, like the Paris Faculty of Medicine, d'Azyr and Lessone sought these powers in order to obtain pay-offs for themselves and for their organization. ${ }^{25}$ In the 1778 patent letters creating the Society, article 10 gave them the right to "examine new internal and external remedies... [and to] order that none of the said remedies should be sold or distributed without the approval of the Society..." Article 12 extended these powers to the approval of mineral water. ${ }^{26}$

In order to carry out these "responsibilities" the $11^{\text {th }}$ and $12^{\text {th }}$ chapters of each of the volumes of the Histoire de la Société royale published analyses of new remedies and sources of mineral water that had been submitted to the Society for approval. In these chapters the members examined and reported on new remedies based on products like cinchona, Epsom salts or ipecacuanha as well as providing analyses of numerous new mineral water sources. This policing of new remedies led to decisions that were often questioned and Vicq d'Azyr had to justify these powers in the 1777-78 volume of Histoire de la Société. ${ }^{27}$ Trying to portray the standards of the Society as professional and demanding, Vicq d'Azyr argued in 1790 that the Society had approved only 4 of the more than 800 drugs and remedies that they had tested. In fact, the archives of the organization tell us a different story, indicating that the group had approved 10 such submissions and temporarily authorized another 34 for a period of four or five years. ${ }^{28}$ But, even the approved remedies were often controversial. En 1774, the correspondents of the Society in Bordeaux wrote to Vicq d'Azyr to denounce a certain Mathis who was selling "anti-venereal enemas" saying that the Society had approved his product. Vicq d'Azyr replied that, in effect, Mathis had received the right to sell his product. ${ }^{29}$ In Languedoc, Constant Chiarini accompanied a circus selling a tonic that wasn't anything more than a vegetable broth and he too said that the Royal Society had approved the tonic. Under questioning, Chiarini admitted to having obtained his authorization from Vicq d'Azyr's valet for 66 livres. ${ }^{30}$

These four volumes reveal a discourse in favor of innovation within the French medical establishment emanating from the period of the Enlightenment and preceding the Paris Clinic. The sessions dedicated to discussions of the morbidity of obesity, the campaigns of inoculation, or the epizootic 

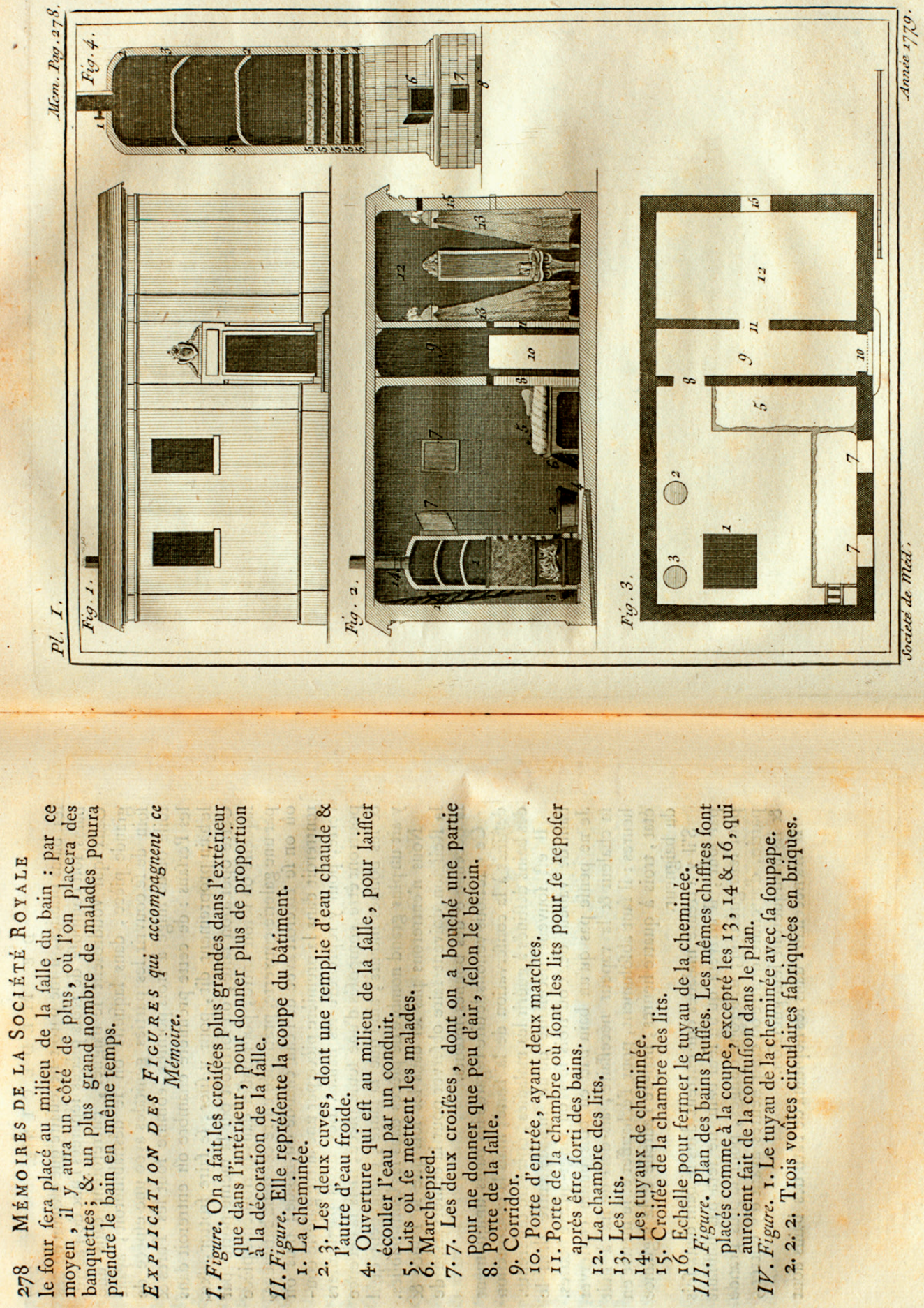
outbreaks certainly enhanced the standing of the Society in the field of public health. At the same time, this work reinforced the group's position with its patrons in the royal court and among the many supporters of Enlightenment research. Medical men were one of the principal groups targeted by the work of the Society. After all, doctors, surgeons and medical researchers were the principal readers of the volumes and the obvious strategy of Vicq d'Azyr was to use obituaries of the "stars" of the profession to create and/ or to reinforce a common mythology and set of values for the medical profession. On a more serious note, it was certainly hoped that country doctors and small town practitioners would learn from the long and detailed explanations of how to perform new types of medical or sanitary interventions. The other principal targets for the Society were the royal court and the patrons of Enlightenment research. The articles on the influence of climate and the regular meteorological observations were clearly meant to show the public health aspects of their work. This, together with the group's experience in dealing with epidemics among animals or human beings was meant to solidify the standing of the Society with its patrons and supporters.

In going through the pages of these volumes, one is struck by the fact that the group is trying to leave behind what they see as centuries of "bookish" medical practice. Their articles are rarely based on previous medical work. There is a new direction behind what Corvisart would call "the clinical gaze", looking beyond the standard medical diagnoses derived from the symptoms described by the patient. ${ }^{31}$ The pages of these volumes describe how meticulous physical examinations, data derived from the dissection of corpses or the observation of natural phenomena were becoming the new basis for analysis, diagnoses and medical hypotheses. It would be up to the Paris Clinic to take the next steps to legislate in these fields, abandoning the Old Regime patronage system in favor of new governmental initiatives in the fields of medicalization and public health.

\section{ENDNOTES}

${ }^{1}$ Histoire de la Société royale de médecine : histoire et mémoires, 1776. Paris : Philippe-Denis Pierres, 1779. Histoire de la Société royale de médecine: histoire et mémoires, 1777-78. Paris : Philippe-Denis Pierres, 1780. Histoire de la Société royale de médecine : histoire et mémoires, 1779. Paris : P. Théophile Barrois, 1782. Histoire de la Société royale de médecine : histoire et mémoires, 1780-81. Paris : chez Théophile Barrois, 1785.

${ }^{2}$ Lawrence Brockliss and Colin Jones. The Medical World of Early Modern France. Oxford: Clarendon Press, 1989, 744-45.

${ }^{3}$ Caroline Hannaway. "Medicine, Public Welfare and the State in $18^{\text {th }}$ century France: The Société Royale de Medicine de Paris (1776-93)." PhD thesis, Johns Hopkins University, 1974, 131.

${ }^{4}$ Erwin Ackerknecht. Medecine at the Paris Hospital, 1794-1848. Baltimore: Johns Hopkins University Press, 1967. Michel Foucault. The Birth of the Clinic, trans by A.M. Sheridan Smith. London: Tavistock, 1973.

${ }^{5}$ Joceline Chabot, Daniel Hickey and Martin Pâquet, Autour de la médicalisation: Perspectives historiques, pratiques et représentations (XVe-XXe siècles). Québec : Presses de l'Université Laval, 2012, 3-8.
'Vicq d'Azyr. "Nouveau plan de constitution pour la médecine en France." Enquêtes et documents relatif à l'enseignement supérieur, 1789-1803. Edited by A. de Beauchamp. Médecine et Pharmacie 28 (1888), 1-158. Also see Brockliss and Jones, 810-11.

${ }^{7}$ Hannaway, 131. Brockliss and Jones add that Lieutaud was very sceptical of the role that the Sociéte was trying to acquire under the direction of Lassone and d'Azyr, especially regarding their attempts to control over approval of new medication and medical treatments as well as over the approval of new sources of mineral water, see Brockliss and Jones, 764.

${ }^{8}$ Lettres patentes du Roi, portant établissement d'une Société Royale de Médecine, données à Versailles au mois d'août 1778, printed in Histoire et mémoires de la Société Royale de Médecine, 1776. Paris : Philippe-Denys Pierre, 1779, 20-21.

${ }^{9}$ Ibid., 21. (This and the following translations are mine.)

${ }^{10}$ Daniel Roche. "Talent, raison et sacrifice: l'image du médecin des Lumières d'après les éloges de la Société royale de médecine (1776-89)." Annales (E.S.C.), 32, 5 ( 1977), 866-67.

${ }^{11}$ Ibid, $870-71$.

${ }^{12} \mathrm{Ibid}, 874$.

13“Éloge de Dr MacBride." Histoire de la Société royale de médecine, 1777-78, 54.

14 "Éloge de Girod." Histoire et mémoires de la Société royale de médecine, 1782. Paris : Philippe-Denis Pierres, 1786, 63.

${ }^{15}$ Daniel Roche, 882.

${ }^{16}$ Lorry. "Sur la graisse considérée dans le corps humaine, sue ses effets, ses vices et sur les maladies qu'il peut causer," Histoire de la Société royale de médecine, 1776, 97.

${ }^{17}$ Brockliss and Jones, 575-78.

${ }^{18} \mathrm{M}$. Daubenton, "Mémoire sur les remèdes les plus nécessaire aux troupeaux," Histoire de la Société royale de médecine, 1776, 312-20.

${ }^{19}$ Hennequin. "Opération césarienne." Histoire de la Société royale de médecine, 1777-78, 236-41

${ }^{20}$ Girod. "Mémoire sur l'inoculation." Histoire de la Société royale de médecine, 1780-81, 231. Also see Girod. "Observations relatives à l'inoculation de la petite vérole." Histoire de la Société royale de médecine, 1777-78, 185-93.

${ }^{21}$ Georges Vigarello. Histoire des pratiques de santé. Le sain et le malsain depuis le Moyen Age. Paris: Seuil, 1993, 180-91.

${ }^{22}$ Histoire de la Société royale de médecine, 1780-81, 27.

${ }^{23}$ Antoine Ribeiro Sanchès, "Sur les bains de vapeur de Russie," Histoire de la Société royale de médecine, 1779, 233-80.

${ }^{24}$ Jean-Pierre Peter. "Une enquête de la Société royale de médecine : Maladies et malades à la fin du XVIIIe siècle." Annales (E.S.C.), 22, 4 (1967), 711-51. Jean-Pierre Peter. "Aux sources de la médicalisation, le regard et le mot : le travail des topographes médicales." Population et cultures : Études réunis en l'honneur de François Lebrun. Edited by Alain Croix. Rennes : Presses de l'Université de Bretagne, 1989, 61-83.

${ }^{25}$ Lawrence Brockliss and Colin Jones also note that the Joseph Lieutaud, the King's physician and the nominal co-president of the Société was very skeptical of the role assumed by the Sociéte royale in approving new medicine, medical treatments and mineral waters. See Brockliss and Jones, 764.

${ }^{26}$ Lettres patentes du Roi portant établissement d'une Société royale de médecine, Versailles, August 1778. Histoire de la Société royale de médecine, 1776, 22-23.

${ }^{27}$ Histoire de la Société royale de médecine, 1777-78, 10-12.

${ }^{28}$ Brockless and Jones, 772.

${ }^{29}$ Ibid, 777.

${ }^{30} \mathrm{Ibid}, 776-77$.

${ }^{31}$ Jean Nicolas Corvisart. "Preface" to the French translation of Léopold Auenbrugger. Nouvelle méthode pour reconnaitre les maladies internes de la poitrine. Paris, 1808 cited in Foucault, 122. 



\title{
"The inconvenience of the present arrangement can only be realized by those who have to work under it": a History of the Legal Research Collections at McGill.
}

\author{
by A.J. Hobbins
}

\begin{abstract}
The origins of McGill University's Faculty of Law and of its law library stretch back to the 1840s. With the formal establishment of the Faculty in 1853, the issue of books and a library became acute. Through donations from a variety of benefactors a respectable collection of books began emerging. Only with Sir William Macdonald's endowment for the Faculty in 1890, however, was ongoing support for the library finally guaranteed. Like the Faculty, the law library moved about considerably until 1949 when both settled into the James Ross property at the north-west corner of Penfield and Peel. Even here, the library has been housed in various locations before moving in 1998 to the Nabum Gelber Law Library.
\end{abstract}

\section{RESUMÉ}

Les origines de la Faculté de droit de l'Université McGill et de sa Bibliothèque de droit remontent aux années 1840. Suite à la création formelle de la Faculté en1853, la question d'une bibliothèque et d'une collection de livres est devenue pressante. Grâce aux dons de divers bienfaiteurs, une collection respectable de livres commença à être établie. Ce n'est toutefois qu'avec la dotation que Sir William Macdonald fit à la Faculté en 1890 qu'un appui financier à long terme fut enfin garanti pour la Bibliothèque. Comme la Faculté, la Bibliothèque de droit s'est vu domiciliée à divers endroits jusquà 1949, quand la Faculté et la Bibliothèque se sont installées sur la propriété James Ross au coin nord-ouest des rues Penfield et Peel. Même après cette relocalisation, la Bibliothèque a occupédivers espaces jusqu’à ce quielle déménage en 1998 à la Bibliothèque de droit Nahum Gelber.

$\mathrm{L}$ aw professors and students at McGill University have often said that nothing is more important to them than the library. This view is generally held in legal academic circles. In 1956, bemoaning the state of Canadian law libraries, the Canadian Bar Association stated:

The facilities for research in Canada are inadequate. This is evident in the lack of proper libraries, of research funds and endowments and research centres and institutes whether within or without the law school. No researcher can work without proper equipment and the principal equipment for most types of legal research is good libraries. ${ }^{1}$

Current surveys indicate a high degree of satisfaction with the library resources-collections, services and study space-but this was certainly not always the case. ${ }^{2}$ The first library dedicated specifically to law was created in 1950, but law had been taught at McGill for more than a century before that. The legal resources available to McGill scholars have had a varied past that will be traced in this article.

\section{Founding of the Faculty}

William Badgley (1801-1888), a prominent Montreal lawyer, was appointed lecturer in law in April, 1844 under the aegis of the recently founded Faculty of Arts. ${ }^{3}$ The first law degrees were awarded in 1850. Up to this point there were no academic or professional requirements to practice law in Lower Canada, but this changed when the Bar was incorporated in $1849 .{ }^{4}$ The Act required all practicing lawyers to be members in good standing. While existing lawyers were grandfathered in, all new applicants had to pass the Bar examination. Qualification to sit the examination was five years articling for a practicing advocate, four years articling if the candidate had graduated from a college or seminary, or three years articling if the candidate followed a law course. On December, 1852 Laval University was incorporated by Royal Charter, and included a law faculty which at the time had no professors or students. ${ }^{5} \mathrm{McG}$ ill created its Law Faculty the following Spring, ${ }^{6}$ and transferred the students already studying law. ${ }^{7}$ Shortly thereafter the Bar Act was amended to allow those with a university or college degree from a law faculty to sit the examinations after three years of 
articling, and articling could be done simultaneously with the course of study. ${ }^{8}$

Badgley was appointed professor and later Dean in 1853. He was also given two colleagues to help with the teaching load-his business partner John J.C. Abbott (BCL 1854, DCL 1867) and Frederick Torrance (BCL 1865). ${ }^{9}$ They each received $£ 500$ from the University plus income from student fees. Nevertheless, they were all part-time and their main income came from continuing practice. Thus, unlike other disciplines, law was not taught on campus because students and faculty spent their days near the law offices downtown and the University was too far away. Classes were given in the evening in rented spaces in somewhat peripatetic fashion. ${ }^{10}$ Classes were originally given in Badgley's law office, but moved to the boardroom of Molson's Bank in 1854. In 1860, law courses were given in Burnside Hall at the corner of University Street and Dorchester Boulevard (now René Levesque) sharing tenancy with the High School of Montreal. ${ }^{11}$ When Burnside Hall was sold to the Protestant Board of School Commissioners in 1870, classes were moved back to Molson's Bank. They returned to Burnside Hall after it had been purchased by the Fraser Institute in 1890. By then plans were in place to create an on-campus Faculty with two full-time academic professors, and in 1896 this move was accomplished..$^{12}$ Initially housed in the East wing of the Arts Building, the Faculty continued to move going to 3484 University Street (1916), back to the East Wing (1922), up to share Purvis Hall with the School of Commerce (1942), before finally acquiring a more permanent home in the Ross Mansion, renamed Chancellor Day Hall (1949). ${ }^{13}$

\section{The University Library}

The University Library (then called the College Library) began as a reading room in the William Molson Hall under the control of an Honorary Librarian. ${ }^{14}$ The collection was made up almost entirely of donations, as was the case for most of the nineteenth century. A number of these donations, and three in particular, were important for the study of law. Frederick Griffin (1798-1877), a local lawyer and book collector, had been counsel to the Board of the Royal Institution during John Bethune's principalship as well as solicitor to the Bank of Montreal. He left his important collection to the University, although only a small portion was devoted to law. ${ }^{15}$ Charles Dewey Day (1806-1884) had been McGill Principal (1853-1855) and Chancellor (18641884). ${ }^{16}$ Between 1859 and 1865 he, with Augustin-Norbert Morin and René-Édouard Caron, drafted Quebec's first civil code. His collection was added to the library in 1885. Finally, towards the end of his life, Judge Robert Mackay (18161888), who had already given his valuable art collection to the Fraser Institute, began donating his book collection to McGill University. ${ }^{17}$ The collection consisted of some 2,000 titles, of which 450 were on non-law subjects, and may at this time have represented $10 \%$ of the total University book holdings. ${ }^{18}$ All these materials were moved to the Redpath Library when this facility was opened in 1893.

\section{The Torrance Collection}

Although the University was building a decent law collection, it was not a great deal of use to the law students. Since they were required to article during the day and take courses near the law courts at night, there was little time to visit the campus. In the beginning they had to rely on the resources available in whichever office they were articling. In 1856, to alleviate the situation the Board of Governors:

Resolved that the President of the Board [i.e. Charles Dewey Day, President of the Royal Institution Board] be authorized to enter if possible into arrangements with the Advocates' Library and with the Section of the Bar for the District of Montreal, for the admission of the Students of the Faculty of Law to the Libraries of those Corporations. ${ }^{19}$

It was not until the late 1880 s, when they had access to collections of the Fraser Institute and, in particular, the Torrance Collection that the situation improved. In 1870 prominent Montreal merchant Hugh Fraser died, leaving the bulk of his estate to John J. C. Abbott and F.W. Torrance, as universal legatees, to do a project he had long discussed with Abbott. His money was to establish in Montreal "an institution to be called the Fraser Institute, to be composed of a free public library, museum and gallery, to be open to all honest and respectable persons whomsoever of every rank in life without distinction, without fee or reward of any kind....20 The Institute was to be modeled on the Institut Canadien that performed a similar service in the French community. A great deal of litigation followed, particularly from Fraser's brother John, and the matter was not settled for over a decade. ${ }^{21}$ Abbott, then a prominent commercial lawyer and Torrance, recently named a Judge of the Quebec Superior Court, were both also McGill professors at this time, with Abbott being Dean. ${ }^{22}$ When the litigation finally ended, the Institute's governors began to create the reality, purchasing Burnside Hall in $18844^{23}$ The Institute library was able to open in October, 1885 having acquired the collection of the Mercantile Library Associate, while that of the Institut Canadien came initially on loan. ${ }^{24}$ Torrance died in 1887 leaving his law library of over 4,000 books and 1,000 legal pamphlets to the Institute. ${ }^{25}$ This was the largest collection of legal materials in the province after the Advocates' Library, and became the more or less exclusive domain of the law students and professors when the Faculty moved to Burnside Hall in 1890. 


\section{The Macdonald Endowment}

It was also in 1890 that the nature and entire future of the Faculty was fundamentally changed. In response to ongoing problems of the faculty, Sir William Macdonald (then plain William McDonald, Esq.) gave the "largest benefaction hitherto received by this University". While he had previously given some modest amounts, Macdonald donated \$150,000 to the Law Faculty for the "extension and improvement of its work. ${ }^{26}$ This endowment created a chair for the position of Dean as a full-time academic, as well as a second full-time chair for the Faculty Secretary. Macdonald also specified that "The remainder of the income shall be devoted to the maintenance and improvement of the work of the Faculty in such manner as may be from time to time determined by the Board of Governors." Norman William Trenholme (18371919), who had been part-time dean, was given that position on a full-time basis. ${ }^{27}$ Archibald McGoun (1853-1921) was hired to the second chair as Professor of Legal Bibliography, Librarian and Faculty Secretary. ${ }^{28} \mathrm{He}$ was given modest amounts to augment and update the resources available to students through the Torrance collection at Burnside Hall. The Macdonald endowment required the faculty to move on campus, but space had to be found to move Science and Applied Science (Engineering) out of the Arts Building. To achieve this Macdonald had the Macdonald Engineering and the Macdonald Physics buildings constructed, which took some time to complete. The Faculty remained in Burnside Hall until 1896, finally having access to an outstanding book collection.

\section{A Long Loan}

The Torrance Collection had been placed in the rooms rented by the McGill Faculty in Burnside Hall rather than in the Institute Library, and had been used more or less exclusively by the students and professors. The Faculty was extremely reluctant to lose this resource despite the availability of the MacKay Collection. Permission was therefore requested, and granted, to have the Torrance Collection removed to the Redpath Library on long loan. ${ }^{29}$ When Frederick Parker Walton was appointed Dean in 1897, he apparently secured a commitment from the University that the 1901 extension to Redpath Library would include a law reading room capable of housing 20,000 volumes and 80 seats. ${ }^{30}$ Thus the Faculty finally had a large law collection situated in one place, although it has been suggested this was not heavily used at first. $^{31}$

\section{The Faculty and the University Library}

The responsibility for the Law Reading Room in the Redpath Library was divided. The University Librarian was given overall responsibility for the collection and the library staff acquired, catalogued and serviced the materials. The Faculty selected new materials from a relatively small grant. Most of the materials purchased were continuations-law reports and journals-while relatively few monographic works were selected. This system appeared to work well enough under the Deanship of Walton (1897-1914) and the tenure of University Librarian Charles Gould (1892-1919). The Faculty Secretary, Archibald McGoun, acted as 'Librarian' (1890-1920). However, in the period following the First World War the relationship became more complex and difficult. The reasons can be briefly summed up as involving the faculty's ambitions, the physical location, staffing, budgets and a new cast of principal players.

In 1918, Dean Robert Warden Lee (1914-1921) instituted his controversial national program, aimed at creating one of the world's great law schools. ${ }^{32}$ Under this program students could get a civil law degree, a common law degree or both. An LLM program was instituted. Courses were also offered to non-law students interested in government and politics. Up to this point the Faculty's mission had been to train lawyers for practice in Quebec civil law, and library resources had been acquired accordingly. Materials would now be required to support common law teaching, as well as foreign, comparative and international law at the undergraduate and graduate student level. Graduates would be able to practice in jurisdictions other than Quebec, although the United States accepted Lee's program rather more readily than the other Canadian provinces. The program also created a dramatic, if temporary, increase in enrollment caused in part by the added offerings but principally because of the large number of returning veterans wishing to take up their deferred studies. This increase naturally placed some strain on available library study space.

When Lee left to take up the Chair in Romano-Dutch Law at Oxford University and McGoun retired, library issues were taken up by H.A. Smith. Smith was an excellent scholar, but was notoriously strong-willed and difficult to deal with. ${ }^{33}$ For this reason he was not appointed Dean but given the role of Vice Dean, responsible for internal faculty affairs, while the deanship was given to a part-time instructor, Justice R.A.E. Greenshields. Following Charles Gould's death, Gerhard Lomer served as University Librarian (1920-1947). Smith served on the Library Committee under the chairmanship of Casey Wood. Following one meeting he wrote to Wood summarizing his concerns about library service for the faculty, stating:

It is obvious this involves a corresponding development in the library. At present we are pretty well provided with books on the civil law, both the old French law and the modern jurisprudence of this Province. But on the English law side, which includes American books, we are extremely weak. To build up a really first class library we need a large sum for immediate purposes and a substantial endowment to keep us up to date. In this connection 
I should like to emphasise the importance of having a good collection of old books and of books bearing on the historical side of the law. Law and history have always been very closely allied, and we must have a library which will attract the scholar and the research student, as well as the man who merely desires a professional education.

Our books are housed in two rooms of the Redpath Library. From Dr. Lomer and his staff we have always received every possible assistance, but the inconvenience of the present arrangement can only be realized by those who have to work under it. ... If our teaching and writing is to be really of the first order it is essential that we should have our library under our own roof. ${ }^{34}$

Wood replied that he sympathized with the problems and would cooperate to the extent possible. ${ }^{35}$ Meanwhile the Library had its own difficulties with the law collection. On discovering a mutilated book, Lomer wrote stiffly to Smith that "If the mutilation of law books continues we may have to consider the question of restricting the access of students to the Law Library."36

Smith's concerns were evidently taken seriously and considered in the plans for the 1921 Redpath extension. The first item of the proposal stated:

Old Law Library Room to be cleared and books placed on the top floor of the Old Stack, access to which will be obtained by cutting a staircase through the floor of the present New Law Reading Room. This portion of the Stack to be separated from the rest by a grating. Additional table space to be provided in the New Law Reading Room, and current law periodicals to be moved to the southern side of the adjoining gallery over the Main Reading Room. ${ }^{37}$

Ten days later, Lomer provided statistics on the size of the law collection: in the Law Library proper, 4,826 volumes; in the Law Reading Room 2,177 volumes; uncatalogued 5,000 volumes (which would have included the Torrance Collection) - for a total of 12,003 volumes. He indicated the Faculty had received a budget of $\$ 1,000$ in each of the preceding five years, and had acquired an average of 225 volumes each year. ${ }^{38}$

In 1923 the Faculty moved back to the East Wing of the Arts Building and a law library was created on the top floor. The University Librarian remained responsible for the collection and services, and Frances W. Lee, a cousin of the previous dean, was hired as the librarian. Lomer made it clear that no changes in service hour or staffing could take place without his approval. ${ }^{39}$ Smith happily offered the services of the library to members of the Montreal Bar at such times as the Court House Library was closed. ${ }^{40}$ This reading room contained only a portion of the law books both because of limited size and the floor lacked the strength to support book stacks. The larger part of the collection was stored in various places because the Redpath Library was too overcrowded to keep it. ${ }^{41}$

By 1927, Smith had resigned and was replaced by Percy Elwood Corbett (B.A. 1914). ${ }^{42}$ Lomer wrote to Corbett about the storage problem, proposing an approach to the Board of Governors:

I am as anxious as the members of your Faculty are to have these volumes out of storage and readily accessible; and I feel that a definite memorandum on the lack of accommodation for the Law Library should be included in the Annual Report of the Faculty and should be otherwise brought to the attention of the Governors. ${ }^{43}$

The Faculty adopted a resolution on the question at its meeting of March 7, 1927 noting "Consequently, a great number of very valuable books have been stored from time to time wherever space was available, having been housed for the last year in a stable", and forwarded it to the Board. ${ }^{44}$ The books in the poor conditions of the stable were boxed and unavailable. At their meeting of April 4, 1927 the Governors sympathized and resolved that something should be done, but could think of no practical solution to the matter. ${ }^{45} \mathrm{~A}$ temporary solution came within a year when it was reported: "Many applications have been made for books formerly packed away in cases. These are once more available, having been placed on shelves in the principal's garage." ${ }^{46}$

By 1929 Lomer evidently had become a little tired of the problems created by the Law library, and the associated costs to the University Library. He wrote to Corbett complaining of the amount of work done for the Law library and suggested the time might be right for the Faculty to follow the model of the Medical Library, with its own budgets and staff. Failing that, he noted "Miss Lee, who is not overworked, should undertake the cataloguing" or the Faculty should make some budgetary provision for the work done by the Library Staff. Nothing seems to have come of this initiative.

When Principal Currie died in 1933 the stored law collection could no longer be kept in the garage of the Baumgarten mansion. After further temporary housing, a longer term solution was found. Lt. Col. Erskine Buchanan (B.C.L. 1921) wrote to Dean Corbett, enclosing plans of the Workman Building attic describing the "...proposed space to be allotted to the law books which are now stacked in the Dining Room of our present building" ${ }^{\prime 7}$ The attic was capable of holding 10,000 volumes, which brought all the stored materials together although the librarian complained of a low, sloping ceiling. 


\section{The Struggle for the Torrance Collection}

On Hallowe'en, 1929 the faculty received an unpleasant surprise, when the Fraser Institute Librarian, Pierre de Crèvecouer (1862-1930), wrote to Stuart LeMesurier, requesting the return of at least part of the Torrance Collection:

....[E]nclosed please find the list of books belonging to the Fraser Institute. I have marked a few volumes that we would be glad to keep in our library. I must see our president, Mr. E. Lafleur, about the others. I suppose he will wait until next meeting of the Board to decide the fate of these volumes.

Eugene Lafleur (1856-1930), considered one of the most outstanding advocates of his day, was a McGill graduate (B.A. 1877 and B.C.L. 1880) and a professor in the Law Faculty (1890-1921). Despite his name, the fluently bilingual Lafleur's mother tongue was English and he was raised a Protestant. ${ }^{48} \mathrm{He}$ served as President of the Fraser Institute from 1915-1930. Anxious to retain the collection, Dean Corbett requested a meeting to discuss the matter. The Fraser governors agreed, naming Lafleur, John Fair and J.W.A. Hickson to represent them. ${ }^{49}$ The McGill delegation consisted of Corbett, Lomer and LeMesurier.

Prior to the meeting Lomer asked LeMesurier to obtain a copy of the bequest. ${ }^{50}$ Lafleur provided them with a brief extract from will which stated:

"... I give and bequeath all my library of books, bound and unbound, to the "Fraser Institute" of Montreal, for the public purposes of such Institution. To have and to hold such bequest to said Fraser Institute in property forever." 51

At the meeting on January 16, 1930 Corbett proposed that McGill retain the Torrance Collection, but provide the Fraser Institute with runs of duplicate journals. The Governors agreed to "think it over".52 Following the meeting, LeMesurier again requested more information about the will from one of Lafleur's partners. The response stated:

As regards Judge Torrance's Will, Mr. Lafleur does not consider it necessary to obtain a full copy of the Will and has instructed me to go through the Will for any other references that there may be to the disposition of books or to the Fraser Institute..$^{53}$

Although Smith noted there were no further references to the books or the Fraser Institute, Lafleur's reluctance to provide a full copy of the will was not without future significance. Whatever Lafleur's final decision may have been, the matter was dropped when both he and De Crèvecouer died a few months later.

Again nothing was done following an inquiry about the books in 1934. Dean Corbett requested time to replace important volumes before returning the collection. ${ }^{54}$ It was not until May 1938 that Hickson, now Acting Chairman of the Board for the octogenarian President John Fair, requested the return of the books. ${ }^{55}$ Lomer reminded the Faculty library representative, F.R. Scott, of the request a few months later, writing:

I find no definitive conclusion has been reached regarding the Torrance collection of law books apparently deposited in this library on long loan. The Fraser Institute library has asked for their return but I understand the Dean wishes to make some effort to retain the books at McGill. ${ }^{56}$

Scott responded:

...our feeling is that before the books are removed from our library, thus leaving serious gaps on our shelves and only adding to the Fraser Institute Library what would be an almost useless collection of law books, we would like to discuss the possibility of continuing the present arrangement... ${ }^{57}$

Scott then wrote to the Fraser Librarian, Miss A.G. McDougall, stressing the importance of the collection to the Law Faculty but noting that the collection itself, without the law library purchases surrounding it, would be of little value to members of the public since the books were more than forty years old. He proposed, should the Fraser Board agree, that any members of the Institute could use the collection at McGill if it remained there. ${ }^{58}$ Hickson rejected this suggestion and McGill prepared to return the books. ${ }^{59}$

Scott, however, continued to argue, writing again to McDougall:

[I]ncidentally you may be interested to learn that the separation of these books from the McGill collection produces some odd results. For instance, Vol 1 of the Canadian Supreme Court reports belongs to you, whereas vols 2 to the current volume belong to us. Hence you will have a single lonely volume of the reports, while we have a broken set. The removal of the important sets of Locré and Marcadé creates a gap that we are obliged to fill, since these are reference works; I wonder whether you will have one inquiry in five years for these authors in the Fraser Institute? However, if the letter rather than the spirit of the law is to be followed I suppose there is no solution to this result. ${ }^{60}$

McDougall's response was not encouraging.

After thoroughly discussing once more the question of the Torrance law books, the Governors decided they could not do otherwise than abide by the decision reached by our late President, Mr. Eugene Lafleur when he took this matter up with $\mathrm{Mr}$. Corbett in 1930. 
I deeply regret all the trouble the removal of these books from your library must cause you and the Librarians in charge. ${ }^{61}$

Lomer made one last attempt by writing to the President, John Fair:

Though I feel that you may perhaps not wish to discuss the matter further, I have a strong conviction that, as the circumstances having materially altered since 1930, owing to the regretted closing of the Circulation department of the Fraser library, it is highly desirable that, in view of the present situation, the matter be re-opened with a view to ascertaining whether the books in question are not of more use at McGill, where they are available for your readers, than they would be if they were transferred to the Fraser Library, where a diminishing staff would have difficulty in handling them. I feel, moreover, that, as neither the late Mr. Eugene Lafleur nor Mr. Corbett is directly connected with the law Library at McGill, a solution of a situation eight years ago should not be binding at the present time and the chief question to be considered is where the books can be of most use. $^{62}$

When Hickson, who had always been uncompromising of the issue, became President in October 1939, he renewed his insistence. The collection was returned over the next few months.

The saga of the Torrance collection has a sad ending. All of Scott's thoughts about the utility of the collection to the general public and Lomer's concerns about the ability of the Fraser Institute to manage the collection were amply justified. It was not until 1950 that the books were catalogued and made accessible. As Scott predicted, usage of the collection that had not been updated for sixty years was minimal. When the Institute (now the Fraser-Hickson Institute following Hickson's death) sold Burnside Hall to developers in 1957 and planned its move to NDG, thought was given to getting rid of what was now considered a white elephant. George Campbell, who had been Hickson's lawyer, gave his opinion on the terms of Torrance's will:

The phraseology adopted by the late Mr. Justice Torrance, "to have and to hold such bequest... in property forever", is reproduced almost identically several time in the will... Perhaps, therefore, too much significance need not be attached to that form of words, which was evidently a clause de style of the drafting notary... Even if the terms of the Torrance will were violated, only the residuary legatee would be in a position to complain.

He concluded that, since McGill University was in fact the residuary legatee, it would not be in a position to complain if the collection was offered back. ${ }^{63}$ The Governors adopted this view. Edgar Moodey commented on Campbell's advice, noting: "One can understand Eugene Lafleur's failure to raise this point, but it is a little mystifying that, in the past, it had escaped the ingenuity of the law faculty of the university." ${ }^{16}$ Perhaps Moodey would have been less mystified had he known Lafleur declined to provide the complete will to the professors, and they were unaware of repetitive language or the fact McGill was the residual legatee. Furthermore, the action was solicited nearly twenty years earlier when the collection had significant value.

The law librarian was asked to view the collection:

....all the Torrance collection was returned to the University: I recall going to Morrice Hall in 1958, sorting out books and making a selection of what we wanted to add back to the collection. The remainder was given to the University of Montreal. ${ }^{65}$

One cannot help but feel Torrance might have wished the saga had unfolded differently.

\section{Purvis Hall}

J.W. McConnell purchased and donated Purvis Hall to the University in 1941 and, in the following year, the Faculty of Law and the School of Commerce were located there. The main floor was converted to a reading room while book stacks were placed in the basement. ${ }^{66}$ This represented the first time the law collections were gathered together in one building, albeit sharing the space with the Commerce Library. ${ }^{67}$

\section{Chancellor Day Hall}

After eight years in Purvis Hall the Faculty moved into the James Ross mansion, another J.W. McConnell gift, which was renamed Chancellor Day Hall. Dean Sydney Bruneau reported enthusiastically on "...the ample classroom and library accommodation...." ${ }^{68}$ For the first time the faculty had its library, now numbering some 16,000 volumes, in unshared quarters under one roof. The library had sufficient staff to take over its own technical services, and collection funding was adequate. However, not all the collection could be placed in the reading room and many books were still stored in basement stacks and professors' offices. Although it had taken sixty years to reach 16,000 volumes, over the next fifteen years another 23,000 volumes were added. ${ }^{69}$ Thus, as in times past, the main problem was always space.

In 1967 a new building was erected, named New Chancellor Day Hall, in which the top four floors were devoted to the Law Library. The Faculty started the National Programme the following year and common law was again taught, requiring library support. ${ }^{70}$ For the first time all materials were placed on the open stacks and became readily accessible. There were sufficient staff resources to publish the important annual reference works Index to Canadian Legal Periodical Literature 
and World Wide Space Law Bibliography. ${ }^{71}$ The collection, however, continued to increase at an alarming rate, adding another 50,000 volumes in the ten year period $1965-1975 .{ }^{72}$

\section{Other special collections}

In 1951 the Institute of Air Law (now the Institute of Air and Space Law) was founded at McGill, largely at the initiative of John Cobb Cooper. This was done in cooperation with the UN's International Civil Aviation Organization and the International Air Transport Association, both headquartered in Montreal. One of the world's best collections in the area was developed and this was augmented following Cooper's death in 1967 when his collection came to the library. When John Peters Humphrey retired from the United Nations in 1966, he donated his collection of primary UN materials in the area of human rights. This collection was later found to contain the first manuscript drafts of the Universal Declaration of Human Rights. ${ }^{73}$ The original collection has become less important as these materials are digitized but Humphrey left a major endowment for the purchase of materials in the area of the international law of human rights, and so a strong collection has been maintained. Perhaps most important was the acquisition of the Olivier-Martin collection on early French private law. This is known as the Wainwright Collection as it was purchased and donated to the library by Arnold Wainwright (B.A 1899, BCL 1902). ${ }^{74}$ F.R. Scott, a member of the Royal Commission on Bilingualism and Biculturalism, presented all the manuscript papers associated with the Commission. ${ }^{75}$

\section{A Growing Crisis}

While one might imagine the move to New Chancellor Day Hall would have been the beginning of a golden era for Law Library users, this was not the case. Complaints began to come in early on. In 1974, the chair of library users committee wrote to the law librarian concerning structural alterations, stating:

The main problem is noise, a problem which has become severe with the unexpected growth of the student population in the law school, and with the installation of noise-making devices such as Xerox machines.

The main feature of the changes should be the elimination of the center stairwell of the library, which functions as a noisewell to permit the drift of noise from one floor to another. ${ }^{76}$

This suggestion was sent to the highest levels of the University but was not acted upon at this time. Indeed, VicePrincipal S. B. Frost had earlier noted the "necessity of placing as much money as we can into book purchase accounts."7
The thought of spending significant sums on renovating a relatively new building did not appeal at this time.

Since professors found the library unsatisfactory for their research, the Law Reading Room was created in the old mansion with key serial titles so the professoriate would not have to go to the library. A second satellite library, the Faculty Reading Room, was later created across the road in the J.K.L. Ross mansion, where Paul-André Crépeau directed the Civil Code Revision Office. The library itself often held duplicate subscriptions to continuations so the second copy could be routed to interested faculty. This meant that for the major Canadian titles the library often purchased four or even more subscriptions.

Matters grew worse in the 1980s. The cost of labour and materials began spiraling upwards. The emphasis on purchasing multiple copies of continuations obliged the library to begin putting parts of the collection in various storage areas in the two buildings. In 1984 the central staircase was removed and floored over, not because it was a 'noisewell' but in the desperate search for more space. The alteration had a negative effect in terms of lighting and, especially, ventilation. The library became an unpleasant place to work. Security also became a major problem. The library had a key-operated staff elevator that allowed faculty to come and go without passing the service desk and security gates. Inevitably, almost every student obtained a copy of the key and losses began to mount. By June, 1988 over $90 \%$ of the following year's serial budget had been taken up in previous over-expenditures. The Faculty had begun to emphasize scholarly publication over black letter law, which required a much greater collection of scholarly monographs for which the library had no funds. The library as it operated was no longer sustainable and difficult changes had to be made.

The 1990s saw dramatic changes in the services offered by the Law Library. Many of these changes removed privileges that the Faculty had long enjoyed. Duplicate subscriptions were cancelled, which meant the two satellite libraries were not kept up to date and periodicals were not longer routed to faculty. ${ }^{78}$ Titles in the library but available elsewhere at McGill were also cancelled and, eventually, unique but little used titles were also dropped. The staff elevator was rekeyed, but keys were not issued to professors. Technical services were centralized once more with the main library, and staff transferred with the work. Law had remained aloof from the central system's automation project for somewhat unusual reasons. ${ }^{79}$ This view changed and the collection was barcoded and its records converted to machine readable form. This allowed the first proper inventory for many years, while introducing the automated acquisitions, cataloguing and circulation systems.

Despite the difficulties many of these decisions caused, there were also brighter sides. The Library took a lead role in the development of a local area network for the Faculty, 
which provided email and word-processing facilities to everyone's desktop. ${ }^{80}$ As more and more resources appeared in electronic form, these materials were also delivered lessening the pressure on print resources. Most important of all, the faculty was taking important steps. Discussions were initiated to replace the National Programme, where the second degree was optional, with a Trans-systemic Program, where civil and common law concepts were taught in the same class and students would be obliged to take both degrees. It was felt that this unique curricular departure would require, amongst many other things, a first class research library. The building of a new library became the only faculty goal for the capital campaign. It became apparent early on this goal would not have support from either University ${ }^{81}$ or government funding, so would have to be financed entirely from private donations. Every professor donated to the project, along with law firms and many alumni. When the principal donor Nahum Gelber (BA 1954, BCL 1957), for whom the library would be named, made his contribution the project became a reality.

\section{The Nahum Gelber Law Library}

The new library opened in 1998, just as the Trans-Systemic Program was starting. It was an extremely pleasant place to study with a great deal of natural light and inspiring art work. There were seminar and moot rooms, as well as an electronic classroom. The classroom became very important for the teaching of legal research and methodology since the preponderance of legal resources were now in electronic form. Every user space was wired for electricity and internet access as it was expected nearly all students would soon have laptop computers. ${ }^{82}$ Old and rare books were stored for the first time in a climate controlled room. The amount of shelving in the new library was about the same as the old one, but the move allowed for the discard of many unnecessary duplicate runs. Furthermore the compact shelving in the basement was user accessible. Campus-wide subscriptions to major databases as well as legal databases available freely on the internet allowed the cancellation of all but core journal and case report titles. The library was therefore free to concentrate on building up a monograph based research collection. By 2003 over half the library collection budget was spent on books, and successful application for rattrapage funding allowed significant historic gaps to be filled. The library no longer restricts itself to purchasing only French and English titles, but collects important works in most major languages.

Despite the high indicators of user satisfaction in LIBQUAL surveys, there are complaints about the Gelber Library. When the library was in New Chancellor Day hall students complained about a lack of seating at examination time. Surveys undertaken then indicated there were always over forty seats free. ${ }^{83}$ The same complaint is echoed about the Gelber Library but with much greater reason. Since the Gelber Library is an extremely pleasant study environment, far more so than the old library, students from other faculties come from far and wide to prepare for exams. Seating is hard to find and tensions arise between law and non-law students at this stressful time of year. ${ }^{84}$ Various policies have been employed to alleviate the situation, but with no very great success since all McGill students enjoy equal rights to use all McGill libraries. However, in the last few years, the University library system has made major renovations to a number of libraries, making them far more attractive places to study. Hopefully this will lessen the pressure on the Gelber facility.

\section{Conclusion}

The Faculty of Law, despite placing the highest emphasis on library resources, has not always been well served in this regard. In its first century it had no library and, though the materials were plentiful, they were frequently scattered and all but the core materials were inaccessible. The principal problem was lack of space both in the University Library and in the many locations to which the Faculty moved until it found a seemingly permanent home. Even following the move to the Old and New Chancellor Day Halls, collection building tended to concentrate on primary materials-legislation and court reports-and journal subscriptions. Research collections only existed in a few narrow areas such as air law, old French law, and human rights. As long as the faculty's mission was to teach Quebec civil law in English, library resources were not a major problem. Most courses used the casebook method, which provided students with key readings and was backed up by a strong collection of practitioner manuals for various aspects of Quebec civil law. Furthermore, most faculty research tended to rely on primary legal materials and law journal articles.

This situation changed for a number of reasons. The introduction of the National Programme in 1968 required building collections for common law jurisdictions that had previously not been purchased. In the 1980s, a growing interest in foreign, comparative and international law developed combined with a significant increase in largely foreign graduate student enrollment. Faculty numbers also increased sharply with correspondingly diverse research needs. The curriculum became much broader, especially after the introduction of the Trans-systemic Program in 1999. The library was obliged to alter its collection policy dramatically to adjust to the new user needs. This would not have been possible but for several factors: the Faculty successfully created a state-of-the-art facility through private fundraising; legislation, case law and journals became available electronically either through commercial publishers or free of charge through government initiatives; the integrated library system allowed for the economic centralization of a variety of services, thus allowing reductions in staff; and, the University supplied an excellent technological infrastructure, 
with its associated support. The Law Library was then free to concentrate resources on building a collection supporting legal research in its broadest terms, and on helping users to adjust to the new technologies. This has been achieved to a major extent. Hopefully the user of today will not experience "the inconvenience of the present arrangement" to the extent H.A. Smith did nearly a century earlier.

\section{Acknowledgements}

The author would like to thank Emeritus Professor G. Blaine Baker for his incisive comments on an earlier draft and his useful suggestions for further sources. The help provided by Theresa Rowat and staff in the McGill University Archives, in particular Mary Ellen Houde and Bruce Dolphin, has proved essential. Isabelle Robitaille of the Bibliothèque et Archives nationales du Québec kindly provided information on her researches into the Griffin Collection. As always, my former librarian colleagues in the McGill Library system were obliging in provided bibliographic details from their collections.

\section{ENDNOTES}

${ }^{1}$ Canadian Bar Association. Committee on Legal Research. "Report". Canadian Bar Review, Vol. 34 (1956), at 1013. McGill law professor F.R. Scott chaired the committee.

${ }^{2}$ Recent LIBQUAL surveys show a generally high level of satisfaction with the collection and services.

${ }^{3}$ S.B. Frost, "The Early Days of Law Teaching at McGill." Dalhousie Law Journal, Vol. 9 (1984), at 153. See also S.B. Frost and D.L. Johnston, "Law at McGill: Past, Present and Future", McGill Law Journal, Vol. 27 (1981), at 31.

${ }^{4}$ An Act to incorporate the Bar of Lower Canada, 1849 (Can.) 12 Vic c. 46. Badgley drafted and piloted this act through the Legislative Assembly. See G. Blaine Baker, "Strategic Benthamism: Rehabilitating United Canada's Bar through Criminal Law Codification, 1847-54", in J. Phillips, R.R. McMurtry, J.T. Saywell, eds., Essays in the History of Canadian Law: A Tribute to Peter N. Oliver (Toronto, University of Toronto Press, 2008), at $257 \mathrm{ff}$. For biographical information on Badgley, see generally Dictionary of Canadian Biography (DCB), vol. XI, 1881-1890, at 40.

${ }^{5}$ The first law students were admitted in September, 1854 after AugustinNorbert Morin was installed as Dean (June 13,1854) and the first three graduates (Robert Alleyn, Charles-Étienne Dallaire and Hammond Gowen) received their LLB degrees in 1856. See Sylvio Normand, Le droit comme discipline universitaire: une histoire de la Faculté de droit de l'Université Laval (Québec: Les presses de l'Université Laval, 2005), at 247.

${ }^{6}$ Principal Charles Dewey Day announced this to the Bar on July 17, 1853.

${ }^{7}$ McGill's first graduates from the Law Faculty received their degrees in 1854.

${ }^{8}$ An Act to declare valid the Articles of Clerkship of Law Students enregistered within a certain period after the delay granted by the Act to incorporate the Bar of Lower Canada, and to amend the said Act, 1853 (Can.) 16 Vic c. 130, s. 6.

${ }^{9}$ Governors' of McGill College Minute Book, 1829-1871., 27 July 1854. McGill University Archives [hereinafter cited as MUA, RG4, cont. 3, File 09003.

${ }^{10}$ For a fuller description of the various premises used by the Faculty, see Ian C. Pilarczyk, A Noble Roster (Montreal: McGill University Faculty of Law, 1999), at $94 \mathrm{ff}$. Pilarczyk gives the University Street address as 746, which may have reflected an earlier numbering.
${ }^{11}$ Space became available when the Faculty of Arts, which had been using Burnside Hall, moved back on campus. See Edgar Andrew Collard, "The High School of Montreal” The Gazette (Montreal), October 4 1943, p. 23.

${ }^{12}$ For the reasons behind this significant change, see A.J. Hobbins, "No longer 'naked and shivering outside her gates': Establishing Law as a Full-time On-campus Academic Discipline at McGill University in the Nineteenth Century." Dalhousie Law Journal, XXXIV (2011), 373-404.

${ }^{13}$ The rationale for giving the Ross Mansion to Law over other claimants is explained in A.J. Hobbins, "'Designating the Dean of Law: attempts to control the nature of legal education at McGill University by the Montreal corporate and professional elite, 1946-1950." Dalhousie Law Journal. XXVII (2004), at 172, note 25 .

${ }^{14}$ Stanley B. Frost, McGill University for the Advancement of Learning. (Montreal: McGill-Queen's University Press, 1980). Vol. I, pp. 247 ff. Molson Hall was later renamed as the West Wing of the Arts building.

${ }^{15}$ Griffin's collection, which covered many subjects beyond law, is currently being analyzed by Isabelle Robitaille of the Bibliothèque et Archives nationales du Québec. See “Frederick Griffin's Library”, Coranto 28 (2011), at 4. Robitaille has not yet analyzed the legal texts but estimates they represent less than $5 \%$ of the collection.

${ }^{16}$ DCB Vol XI, (1881-1890), at 237.

${ }^{17}$ Mackay to William Taylor (assistant in the College Library), May 28, 1885. MUA, RG40, Cont. 2, File 1447 "Mackay Library". This was a covering letter for a donation of books that "will fill up the blanks that ought not to be allowed in the University Library". The file contains many lists of books although it is not clear which books were received during Mackay's lifetime and which came as a bequest.

${ }^{18}$ Peter F. McNally and Christina M. Boyle, "Judge Robert Mackay's 1882 Catalogue of Books: A Preliminary Analysis." Fontanus, vo. X, 1998, at 67. McNally and Boyle analyzed the non-legal titles in the collection based on an 1882 printed catalogue of the collection. The law collection has not been analyzed but, based on the book catalogue, the legal collection has been reconstituted as part of a project organized by McNally and Law Librarian Daniel Boyer. See also G.B. Baker et al., Sources in the Law Library of McGill University for the Reconstruction of a Legal Culture of Quebec, 1760-1890 (Montreal: Faculty of Law and Montreal Business History Project, McGill University, 1987).

${ }^{19}$ Minutes, supra note 9, May $3^{\text {rd }} 1856$ p.190. See also Marianne Scott, "An Historical review of the Development of the McGill Law Library, 1848-1975" Draft manuscript, February 1981. "Law" MUA, RG40, Cont. 234, File 1192, at 4. The Advocates' Library and Law Institute of Montreal was established by a group of Montreal Anglophone lawyers and judges in 1828 and available only to members. Following an agreement in 1853, it was managed by the Montreal Section of the Lower Canada Bar to allow greater access to all lawyers. M. Nantel, "The Advocates' Library and the Montreal Bar." Law Library Journal Vol. 27, 1934, at 88 and M. Nantel, "La Bibliothque du Barreau et les archives judiciaires de Montréal." Revue du Barreau Vol. 6, 1946, at 59. In December 2001, the Bar of Montreal transferred its library to CAIJ (Centre d'accès à l'information juridique), an organization associated with the Barreau du Québec and dedicated to developing and modernizing access to all the legal information available, both in print and electronic. See also Gilles Gallichan, "La Bibliothèque du Barreau du Québec: l'emergence d'une institution", Les Cabiers de Droit, Vol. 34, 1993, pp. 125-152. For developments in Ontariro, see A. Rosemary McCormick, "The Libraries of the Law Society of Upper Canada" Law Society of Upper Canada Gazette, Vol. 6, (1972), p. $55 \mathrm{ff}$.

${ }^{20}$ The full text of Fraser's will is found in the decision of the Judicial Committee of the Privy Council. "The Honourable John J. C. Abbott et alv John Fraser et al” (Canada) [1874] UKPC 72 (26 November 1874), available online at http://www.bailii.org/uk/cases/UKPC/1874/1874_72.html.

${ }^{21}$ Fraser's will was declared valid by Quebec Superior Court in March, 1871. However this decision was overruled in June 1873 by the Court of Queen's Bench (now the Quebec Court of Appeal) in a three-two decision on the basis that a 1743 Edict of Louis XV was still in force. Abbott appealed this decision to the Judicial Committee of the Privy Council in London (then Canada's court of last resort). His appeal was upheld on November 26, 1874 (supra note 20). This should have ended the matter but Fraser's family continued to litigate, attempting to have their brother declared of 
unsound mind and accusing the Institute's governors of various financial improprieties. The matter was not finally ended until 1883. See G.B. Baker, "Law Practice and Statecraft in Mid-Nineteenth Century Montreal: the Torrance-Morris Firm 1848-1868" in C. Wilton, Beyond the Law: Lawyers and Business in Canada 1830 to 1930 (Toronto: Butterworth, 1990), at 45.

${ }^{22}$ Both Abbott and Torrance gained their professional accreditation through articling, but did receive McGill law degrees at a time when both were on the faculty.

${ }^{23}$ Abbott was the first president (1870-1893) and the remainder of the Board had much in common with McGill's Board of Governors. At various times the governors included Sir Donald Smith (later Lord Strathcona), Sir William Macdonald, John H. R. Molson, Peter Redpath and Hugh McLennan, all long serving members of the McGill Board. Torrance also served on the McGill Board from 1870 until his death.

${ }^{24}$ Edgar C. Moodey, The Fraser-Hickson Library: an Informal History (London: Bingley, 1977), at $62 \mathrm{ff}$. The Institut Canadien books remained with the Fraser Institute following the demise of the Institut.

${ }^{25}$ Ibid., at 163 .

${ }^{26}$ Governors' and Royal Institution Minute Book, 5 April 1890, p. 468. MUA, RG4, Cont. 5 (1884-1891). See also Hobbins, supra note 12.

${ }^{27}$ Trenholme (B.C.L. 1865) was the first winner of the Elizabeth Torrance Gold Medal for highest standing. He served as Dean (1888-1895) before returning to private practice, and batonnier of the Montreal Bar (1898-1899). He became a Federal QC in 1889, and served as a judge on the Quebec Court of Appeal (1904-1918). See Henry J. Morgan, Canadian Men and Women of the Time (Toronto: Briggs, 1898), at 1,020, and MacMillan Dictionary of Canadian Biography (Toronto: Macmillan, 1963), at 755 .

${ }^{28} \mathrm{McGoun}$, in addition to his duties as Secretary and Librarian, taught a variety of subjects retiring in 1920, a year before his death. He also continued his legal practice, first with F. L. Beique and then with his own firm McGoun and England. He was created KC (Quebec) in 1905. See Morgan, at 738 and MacMillan, at 456, both supra note 27. McGoun was an avid snowshoer and Scottish dancer; he would have his students snowshoe up to his house, high on the mountain, following which they would enjoy dancing. See Pilarczyk, supra note 10, at 73. For law library developments at Dalhousie University, see Philip Girard, "His whole life was one of continual warfare': John Thomas Bulmer, lawyer, librarian and social reformer," Dalhousie Law Journal (Halifax), 13 (1990): 376-405.

${ }^{29}$ See Moodey, supra note 24 , at 84.

${ }^{30}$ See R.A. Macdonald, “The National Law Programme at McGill: Origins, Establishment, Prospects", Dalhousie Law Journal, XIII (1990), at 243. The author has been unable to verify this commitment which seems remarkably large given the size of both the student body and the Redpath Library.

${ }^{31}$ Ibid., at 242. Macdonald suggests the law reading room was rarely used based on its lack of proximity to the classrooms in the East Wing of the Arts Building. He cites as a source Peter F. McNally, "A Chronology of Events in the History of the Faculty of Law Library," (unpublished manuscript dated March 27, 1975). McNally cannot recall the document but suspects that it may have been part of some correspondence with the then Dean John Brierley. It has not been found and McNally cannot recall the basis for the information.

${ }^{32}$ For a description of Lee's program see A.J. Hobbins, "A couple of generations ahead of popular demand": The First National Law Program at McGill University, 1918-1924.'Dalhousie Law Journal, XXXI (2008). pp. $181-210$.

${ }^{33}$ See generally Macdonald, supra note 30, at 256, note 92. See also Hobbins, supra note 32 , at $196 \mathrm{ff}$.

${ }^{34}$ Smith to Wood, October 12, 1920. "Library" MUA, RG 37, Cont. 1, File 1. The Faculty was then located on University Street.

${ }^{35}$ Wood to Smith, October 17, 1920. Ibid. For biographical information on Wood (1856-1942) see Canadian Medical Association Journal, vol. 46, 1942, at 297.

${ }^{36}$ Lomer to Smith, November 9, 1920. Ibid.
${ }^{37}$ Special Library Committee. Memorandum of Proposed Changes. March 10, 1921. Ibid.

${ }^{38}$ Ibid.

${ }^{39}$ Lomer to Smith, June 4, 1923. Ibid.

${ }^{40}$ Smith to Librarian, Montreal Court House, September 28 1923. Ibid.

${ }^{41}$ See Scott, supra note 19 , at 2.

${ }^{42}$ For biographical information on Corbett, see A.J. Hobbins, "Mentor and Protégé: Percy Corbett's relationship with John Peters Humphrey." Canadian Yearbook of International Law, 1999. XXXVII (2000), pp. 3-56.

${ }^{43}$ Lomer to Corbett, February 10, 1927 MUA, supra note 34.

${ }^{44} \mathrm{Ibid}$.

${ }^{45}$ Secretary of the Board to LeMesurier, April 5, 1927. Ibid.

46"Library", supra note 34. The Principal then lived in the former Baumgarten House at 3450 McTavish St., now the Faculty Club. Scott, supra note 19 , reported that during this time, in addition to the stable, the boxes were stored in the Biology Building (now the James Administration Building), Molson House and Macdonald College. Although there were several Molson Houses near the University, they were not owned by the University. It is more likely Scott was referring to the original Molson Hall, now the West Wing of the Arts Building, which had housed the original University book collection before Redpath Library was constructed.

${ }^{47}$ Buchanan to Corbett, April 15 1935. "Library", MUA RG37, Cont. 1, File 2. Although Buchanan graduated from law before Corbett came to the faculty, it is evident from the salutation "Dear Corby" they knew each other well. They both served in the $13^{\text {th }}$ Battalion (Royal Highlanders of Canada) CEF during the First World War and very likely became acquainted then. The original Macdonald Engineering Building was attached to the Workman Workshops in 1893. Both were rebuilt following the fire in 1907. The McGill contingent of the COTC had taken over 3484 University Street, after the Faculty left the mansion in 1923. McGill News, Vol. 21 (Autumn, 1939), at 8. Possibly the law books had been in this building since the Faculty left a decade before. After the COTC removed to the new Armory in 1941, the mansion became the war-time headquarters of the International Labour Organization. The School of Architecture moved there in 1947, describing the building as a "rambling, neo-medieval mansion with turrets, secret nooks and crannies, and a picturesque but complex roof." Norbert Schoenauer, "McGill's School of Architecture: a Retrospection", in McGill University. School of Architecture and Urban Planning. Prospectus (Montreal: School of Architecture and Urban Planning, 1987), at 17. The building was demolished in 1958 when the McConnell Engineering Building was constructed. Ibid., at 23.

${ }^{48}$ DCB Vol XV (1921-1930), at 607. Lafleur's parents were of Swiss descent and his father, Theodore Lafleur, was a Baptist Minister. Lafleur later joined the Church of England. See also D.R. Williams, Just Lawyers: Seven Portraits. (Toronto: University of Toronto Press for the Osgoode Society for Canadian Legal History, 1995).

${ }^{49}$ De Crèvecouer to Lomer Nov 29 1929. MUA, supra note 47. John Fair (1857-1947) was a local notary who served as the Institute's president (1933-1939). Joseph William Andrew Hickson (1873-1956), a McGill philosophy and psychology professor, as well as a noted mountaineer, was also later president (1939-1945). Hickson left his estate of nearly two million dollars to the Institute provided his name was added to its title. Moodey, supra note 24, at 162 .

${ }^{50}$ Lomer to LeMesurier, December 18, 1929. Ibid

${ }^{51}$ Lafleur to LeMesurier December 26 1929. Ibid.

${ }^{52}$ Moodey, supra note 24, at 128.

${ }^{53}$ H. Larratt 'Laddie' Smith to LeMesurier, January 30, 1930. MUA, supra note 47.

${ }^{54}$ Moodey, supra note 24 , at 128 .

${ }^{55} \mathrm{Ibid}$.

${ }^{56}$ Lomer to Scott, October 25, 1938. "Library" MUA RG37, Cont. 1, File 3.

${ }^{57}$ Scott to Lomer, October 26, 1938. Ibid.

${ }^{58} \mathrm{Scott}$ to McDougall, October 31, 1938. Ibid. 
${ }^{59}$ Moodey, supra note 24 , at 129.

${ }^{60}$ Scott to McDougall, December 23, 1938. MUA, supra note 56.

${ }^{61}$ McDougall to Scott, Febraury 13, 1939. Ibid.

${ }^{62}$ Lomer to Fair, February 24, 1939. Ibid.

${ }^{63}$ Moodey, supra note 24, at 165 .

${ }^{64}$ Ibid., at 166 .

${ }^{65}$ Scott, supra note 19 , at 5 . The Fraser Institute stayed temporarily in Morrice Hall until the building in NDG was ready. Morrice Hall belonged to the Presbyterian College until J.W. McConnell purchased it in 1961 and donated it to the University.

${ }^{66}$ See Virtual McGill at http://cac.mcgill.ca/campus/buildings/Purvis_ Hall.html.

${ }^{67} \mathrm{Scott}$, supra note 19 , at 8 .

${ }^{68}$ McGill University. Annual Report, 1949-1950. at 41.

${ }^{69} \mathrm{Scott}$, supra note 19 , at 8 .

${ }^{70}$ The National Programme allowed students to take either a civil or common law degree and, after studying an extra year, could obtain both. Currie's assessment that Lee's 1918 national program was a "couple of generations ahead of popular demand” proved remarkably accurate. See A.J. Hobbins, supra note 32.

${ }^{71}$ The Index, founded in 1963 by Law Librarian Marianne Scott, was created by staff members Gabor Both and Arnold Banfill. The Bibliography was authored by Head of Public Services Kuo-Lee Li.

${ }^{72} \mathrm{Scott}$, supra note 19 , at 12 .

${ }^{73}$ These drafts along with other Humphrey papers were given to the McGill University Archives in 1989 (MUA, MG 4127). See A.J. Hobbins, "René Cassin and the Daughter of Time: the First Draft of the Universal Declaration of Human Rights". Fontanus II (1989) pp. 7-26.
${ }^{74}$ For the story behind the acquisition of the Wainwright Collection, see M.L. Renshawe and J.E.C. Brierley, "Sources in Civil Law: the Wainwright Collection" Fontanus, vol. I, 1988, at 77 ff. See also M. Scott, "The Wainwright Collection", McGill Law Journal,Vol. 8, 1961, at $57 \mathrm{ff}$.

${ }^{75}$ Scott to Keith Crouch (Director of Libraries) April 11, 1972. MUA, RG 40, Cont. 160, File 207. These papers have since been given to McGill University Archives (MUA MG 2004).

${ }^{76} \mathrm{HP}$ Glenn to Marianne Scott, May 2 1974. Memorandum on "structural changes to the Law Library". "AL Law, 1973-1974" MUA, RG40, Cont. 160, file 209.

${ }^{77}$ S.B. Frost to H.P. Glenn, December 19, 1973. Ibid.

${ }^{78}$ For a while tables of contents of journals and case reports were photocopied and sent to professors, but this labour-intensive activity was also dropped after a few years.

${ }^{79}$ It was perceived that if Law's holding were not in the online catalogue this would lessen the pressure on the library, while law users would have the advantage of knowing the holdings of all other McGill libraries. This viewpoint overlooked the huge advantages of automation that went far beyond the online catalogue.

${ }^{80}$ The Library staff continued in this role until 2003, when local area networks gave way to campus-wide ones and technical support was centralized.

${ }^{81}$ The University did make a loan of $\$ 900,000$ so construction could start. Some eight years later this debt was forgiven so the University became a delayed contributor to the project.

${ }^{82}$ Unfortunately the introduction of wireless technology could not be predicted. The hard-wired internet jacks are hardly used and, even from the first, only half of them were activated at the server end.

${ }^{83}$ Scott to Glenn, February 21 1974, at 1. MUA, supra note 76.

${ }^{84} \mathrm{Law}$ students use the acronym SNAILS (students not actually in law) to refer to non-law users. 



\title{
Discovering a 'Hidden' Collection: Early Printed Books and Old Master Prints in the McGill Library Collected by T.W. Mussen
}

\section{by Svetlana Kochkina}

\begin{abstract}
Thomas W. Mussen (1832-1901) was the rector of the Anglican Church at West Farnham, Québec from 1859 to 1901, and bequeathed his collection of old master prints and early printed books to McGill University. This article describes a special project undertaken by the author in order to reconstruct the collection that has long remained hidden from the research community. This article analyses the book collection under language (5 categories), place of publication (3), date of publication (7), and subject (8) and demonstrates the uniqueness of the collection by comparing it to the holdings of other Canadian libraries.
\end{abstract}

\section{RESUMÉ}

Thomas W. Mussen (1832-1901) était le recteur de l'église anglicane à West Farnham, Québec de 1859 à 1901 qui a légué sa collection d'estampes et livres rares à l'Université McGill. Cet article décrit le projet spécial entrepris par l'auteur dans le but de reconstruire de sa collection longtemps cachée de la communauté de recherche. Cet article analyse la collection de livres en fonction de la langue ( 5 catégories), du lieu de publication (3), de la date de publication (7), et des sujets (8) et prouve le caractère unique de sa collection en la comparant aux fonds des autres bibliothèques canadiennes.

\section{I}

The problem often referred to as 'hidden collections' - that is, those that are uncatalogued, poorly catalogued, unprocessed, or lacking online access - is not something exclusive to the McGill Library. They were the topic of an ARL Task Force (2001-2006) that resulted in the well-known paper "Hidden Collections, Scholarly Barriers," by Barbara Jones published later in the RBM: A Journal of Rare Books, Manuscripts, and Cultural Heritage. ${ }^{1}$ Since the publication of this paper, a considerable body of scholarly and professional literature has appeared, where the threats and hindrances that the issue represents to scholarly research and to the collections themselves, as well as ways of solving this problem on a large or a local scale, have been discussed. An excellent review of the literature on the subject has been offered in the article by Melissa A. Hubbard and Ann K. D. Myers "Bringing Rare Books to Light: The State of the Profession". Despite the efforts of the library community, hidden collections remain a pertinent issue for almost every academic library that has extensive holdings in rare books and special collections. The current article does not offer a solution to this problem, but describes a project aiming to improve access to a particularly interesting example of such a collection: the early printed books and old master prints donated to the McGill Library by the family of T.W. Mussen.

In fact, the Mussen collection is almost a perfect example of a hidden collection because it has suffered or is suffering from most of the problems identified by Barbara M. Jones: ${ }^{3}$

- it is not kept together physically or bibliographically as a separate collection

- wider scholarly community is unaware of existence of many of the items due to the lack of online access. None of the prints and only some books are in McGill online catalogue. Consequently, most of the items from Mussen collection do not appear in AMICUS and WorldCat

- access to the collection as a whole is staffdependent and is threatened by the inevitable loss of institutional memory: the author of the present article learned about this collection in conversation with the Head and Curator of Manuscripts of Rare Books and Special Collections, Dr. Richard E. Virr

+ $\quad$ existing manual finding aides, such as the Rare Books and Special Collections' (RBSC hereafter) 
list of European prints, are extremely difficult to use especially for inexperienced researchers more accustomed to online tools

- print collection is subject to the wear of physical items: due to lack of finding aids, staff have to look through many prints in order to find a particular print

Most importantly perhaps, the existence of the collection has not been documented in any of the widely accessible information sources. The physical collection has been dispersed, and provenance information was found in only 16 catalogue records, one of which had misspelled Mussen's name. To summarise, there is nothing that alerts a researcher to the existence of the Mussen collection, nor is there any way of identifying most Mussen items, despite the historical value of the collection, and the research importance of many individual items.

The collection is potentially of research value to scholars in church history, theology, art history, and library and book history. According to AMICUS, the Canadian national union catalogue, most of the Mussen's books are unique copies in Canada (See section V below), with some being particularly rare such as an exquisitely illuminated folio of Decretum Gratiani, the first dated book printed in Strasburg in 1472 by Heinrich Eggestein, an apprentice of Gutenberg. ${ }^{4}$ In addition to the research value of many individual items, the collection as a whole can serve as a case study on $19^{\text {th }}$ century collectors outside of the main Quebec urban areas.

\section{II}

The collection's creator, Rev. Thomas W.Mussen(1832-1901) was the son of Thomas Mussen, ${ }^{5}$ a well-known Montreal drygoods merchant. ${ }^{6}$ After ordination, he was appointed rector in 1859 of the Anglican Church at West Farnham. Being successful in his duties as a rector, he became later a Rural Dean of Bedford and a Canon of Christ Church Cathedral at West Farnham. During his appointment, Mussen made the parish financially independent, enlarged the church, and constructed a new rectory and parish hall that he designed himself. The complex of Saint-James the Apostle and Martyr Church is listed in the Canadian Register of Historic Places and the Répertoire du patrimoine culturel du Québec. ${ }^{7}$ Mussen was described in the History of Diocese of Montreal as "a man of culture and erudition," with a good knowledge of Latin, Greek, and Hebrew and a "lover of Art", who "possessed a large collection of coins and engravings by the old Masters, also a rare collection of old books". The bulk of this collection was purchased during his grand tour of Europe in 18561858. Although at his death in 1901 Mussen did not leave any formal bequest, he had expressed the wish that his collection be donated to McGill University, ${ }^{9}$ the institution where he began his higher education. ${ }^{10}$ Consequently, the major part of his collection of early printed books, old master prints, and
Greek and Roman coins was donated in 1919 to the McGill Library by his widow and daughter, Mrs. Mussen and Miss Caroline E. Mussen, while a second, less significant, donation was made in 1941.

The 1919 donation was recognised at the time as "an exceptional gift" in the Montreal Gazette. ${ }^{11}$ The collection included, among other items, seven incunabula and prints by Durer (e.g. the famous Four Horseman of Apocalypse), Lucas van Leyden (e.g. Saint Madeleine), and Rembrandt (e.g. The Descent from the Cross), the latter of which was the subject of an article by Maria L. Brendel. ${ }^{12}$ Regrettably, although this collection was recognised as "one of the most important additions which the Library has received in many years,"13 it was not kept together as a separate entity. The Mussen's Greek and Roman coins collection was described in 1991 by Richard E. Virr et al. published in Fontanus, ${ }^{14}$ and this new project was undertaken to reconstruct the remaining Mussen prints and book collections.

\section{III}

In reconstructing the collection, the author was advised and guided by Dr. Richard Virr, with the goal of identifying, describing, analysing, and making accessible to the public a collection of the rare prints and early books donated to the McGill Library by T.W. Mussen and his family.

Access to the Mussen prints was difficult and incomplete as there is no comprehensive donation list, or records in the online catalogue. An approximate figure, "over 110 early engravings" is given in the Quarterly and Annual Report of the Librarian, 1917-1920..$^{15}$ Some of the Mussen prints have been included in the Rare Books and Special Collections "European Prints" typewritten listing, along with other prints, listed and numbered according to their order in the physical collection. At the time, the most complete inventory of prints was a carbon copy of the pages numbered 3 and 4 of a type-written inventory, "Mussen Memorial", which listed a portion of the prints and was found in the Thomas Mussen file. ${ }^{16}$ However, no references were found from the "Mussen Memorial" list to "European Prints", so the Mussen prints were almost unfindable in the physical collection. The Mussen Memorial list (M.M.l. hereafter) contains 114 items, that are handnumbered from 1 to 83 (several items being grouped under one number), while 11 items are marked with "W" in the same hand-writing. There is a type-written note at the end of the list: "several other engravings, by unknown persons, and of less va[lue ]"17 It can be assumed that the numbering was done during an inventory that took place sometime after the donation had been accepted by McGill, and "W" could mean "wanting" because none of the prints marked with "W" have been found.

In order to identify the Mussen prints, they were all crossreferenced against "European Prints, ${ }_{18}^{18}$ where some of them are listed in two separate sub-sections. A random search 
revealed that other Mussen prints are listed in "European Prints" but are identified only with difficulty after a timeconsuming search because of the ad hoc organisation of the catalogue. This listing has no index, and donors are identified randomly if at all. The entries in the catalogue are not in any alphabetical or other order. In addition, RBSC's possesses a large number of uncatalogued prints that do not appear in "European Prints", so this approach of cross-referencing was soon abandoned. Since all Mussen prints have a Mussen Memorial stamp and a number on the verso, and most of them have this own "Rev. T.W. Mussen" label, they can be easily identified by examining the physical items. A decision was made to examine physically the entire collection of European prints amounting to 1,605 catalogued and more than 900 uncatalogued items.

As a result, a comprehensive catalogue of Mussen's prints has been compiled: 112 prints, including 98 appearing in the Mussen Memorial list and 14 not included in the list, with 16 identified as missing. A short description has been provided for all uncatalogued prints, and authority work has been done using, among other sources, the database of the RKD (Rijksbureau voor Kunsthistorische Documentatie/ Netherlands Institute for Art History), ${ }^{19}$ Grove Art Online, and Oxford Art Online. Finally, some basic conservation measures were taken to protect several fragile prints.

\section{IV}

The next stage of the project was identification of Mussen books, catalogued and uncatalogued, in the McGill Library. As no list of the books donated to McGill was found, the potential total was unknown. For technical reasons, the Library's accession registers were unavailable for consultation until late in the project. At the time, the McGill online catalogue identified in notes only 16 books as donated by T.W. Mussen or by his daughter, Miss C.E. Mussen. The most comprehensive inventory was a shelf-list, a small binder with $3 \times 5$ hand-written cards listing the 46 oldest and most valuable Mussen books. However, a comparison of online search results and the shelf-list revealed that there is no complete overlap between them, indicating that neither can be considered exhaustive.

To compile a comprehensive list of Mussen book collection the McGill University Archives were consulted. The carbon copies of three letters were located in the Library's Outgoing Letter Book from the University Librarian, Charles $\mathrm{H}$. Gould, to Mrs. and Miss Mussen. ${ }^{20}$ These letters confirmed the existence of typewritten list of the first lot of books donated to McGill Library in the beginning of January $1919^{21}$ - possibly pages 1 and 2 of the Mussen Memorial list. Also, they permitted identification of some Mussen books, because the letters from January 31, $1919^{22}$ and February 10, $1919^{23}$ listed the second and third lots of books. In addition, these letters led to an article "Notable gifts to M'Gill library" about the donation that was published in the Montreal Gazette in 1919. ${ }^{24}$ Examination of the McGill University Annual Report of the Governors, Principal, and Fellows for the year 1918-1919 established the total number of volumes donated to the McGill Library in 1919- "76 volumes, consisting of early printed works, many of them of great value."25 It should be noted that the number 76 could be interpreted in two ways: first and most probably, as a number of titles given to the library, second, as number of physical volumes. For the purpose of this research, it is assumed that the number " 76 " represents the number of individual titles donated to the McGill Library by the Mussen family and not a number of physical volumes constituting multivolume sets.

By comparing information from the University Librarian letters, the $3 \times 5$ cards binder, RBSC card catalogue, McGill Library online catalogue, and McGill Library accession registers, 73 titles of 76 , donated to the McGill Library by the Mussen family in 1919, were identified. Later, eight more titles previously belonging to T.W. Mussen have been found. The date of donation of those eight books cannot be confirmed by any archival evidence but can be established as before 1940 according to the accession information. Of 81 titles 74 physical books have been located. The provenance of all the books has been confirmed by examining the physical copies for the presence of the donor plate, donor stamp, T.W. Mussen's bookplate, or his signature.

When the identification of the books donated to the McGill Library in 1919 was nearly completed, an unsigned one-page draft document, Presentations to the Redpath Library June-194126 was discovered by RBSC's Curator of Manuscripts in a document file. This document suggested that another donation was expected in 1941 from the estate of the late Miss Caroline E. Mussen. However, in the Annual Report 1941-194227, the total number of accepted books from Miss Mussen estate is not given, and there are no references to the donated prints or to the overall size and to any value of the donation. Examination of the accession registers for the years 1940-1947 (1947 being the last register preserved) has revealed that only $\operatorname{six}^{28}$ titles from Miss Mussen's estate were placed in the Library's collection during the period 1941-1947. The McGill Archives produced no list of donated books either in the correspondence files or in the Annual Report 1941-1942. ${ }^{29}$ The correspondence ${ }^{30}$ between Vice-President and Managing Director of the Crown Trust Company, J. Rexford, and University Librarian, G.R. Lomer, states that Miss C.E. Mussen's "will was made prior to 1919",31 and "all [her] rare and valuable books, engravings [...] and coins" ${ }^{\prime 2}$ mentioned in the will as bequeathed to McGill were already donated to McGill Library in January 1919, and "the records of the estate show a list of these books and a receipt".33 In addition, the references in the correspondence to the fact the books that are "not now selected by McGill go to the Montreal Diocesan Theological College" ${ }^{\prime 4}$ also support the assumption that the total number of items from the Mussen 
collection accepted by the McGill Library in 1941 was not significant.

\section{V}

Despite the fact that it has been impossible to reconstitute the entire Mussen book collection ${ }^{35}$, the description of 87 titles donated in 1919 and 1941 gives an understanding of the scope of the collection. Some of the most interesting books include the previously mentioned Decretum Gratiani (1482), a folio magnificently illuminated with floral motives; Compendium de Origine et Gestis Francorum (1497) by Robert Gaguin, renowned French Renaissance humanist and philosopher, the first work on the history of France breaking with the medieval historical tradition; a Venetian edition of the famous Canzoniere, Le Cose Volgari di Messer Francesco Petrarcha (1501), the first Italian book printed in italic type; an English translation of the Il Libro del Cortegiano (1577), the definitive account of Renaissance court life by Baldassare Castiglione, one of the most widely distributed books of the $16^{\text {th }}$ century; and Athanasii KircherieSoc.Jesu Chinamonumentis (1667), bound in vellum and richly illustrated with splendid engravings based on explorers' sketches and original images brought from Asia. The collection bears the evidence of Mussen's book collecting and bibliophilic practices. Mussen's 54 earliest books have his bookplate on the front pastedown. 11 books printed in $15^{\text {th }}$-early $17^{\text {th }}$ centuries, have laid within them correspondence with booksellers, newspaper clippings, or notes dealing with provenance, other copies, value, or rarity of the book: an example is Mammotrectus Super Bibliam (1487).

At present, the collection is composed of 87 titles, including eight titles bound together in three volumes. ${ }^{36}$ The majority of the books, 61 early printed books and 7 incunabula, which constitute $78.2 \%$ of the collection, were printed in the hand printing-press period, before 1850 , and almost $50 \%$ of the collection is comprised of the pre- $18^{\text {th }}$ century imprints (see Table 1). ${ }^{37}$

Table 1

\begin{tabular}{|l|l|l|}
\hline Date & \# Titles & \% \\
\hline $1472-1500$ & 7 & 8.1 \\
\hline $1501-1600$ & 21 & 24.2 \\
\hline $1601-1700$ & 15 & 17.2 \\
\hline $1701-1800$ & 15 & 17.2 \\
\hline $1801-1850$ & 10 & 11.5 \\
\hline $1851-1900$ & 18 & 20.7 \\
\hline $1901-1999$ & 1 & 1.1 \\
\hline Total & 87 & 100 \\
\hline
\end{tabular}

In order to prove the uniqueness of the Mussen collection and thereby, its significance for the scholarly community, a comparative survey of the holdings in Canadian libraries has been undertaken. First, every title has been checked against the holdings of other Canadian libraries (same edition, date and place of publication), using AMICUS, ${ }^{38}$ the Canadian national union catalogue. A considerable amount of inaccuracy in the AMICUS records has been discovered with regard to the physical format of the items, (e.g. printed items have been found linked to microform records and vice versa). Therefore, the holdings of each library reported in AMICUS as owning copies of the titles included in the Mussen collection, have been verified using their local online catalogues. As a result of this survey, it can be concluded that the collection donated by the Mussen family to McGill is indeed a notable and exceptional gift ${ }^{39}$ and a valuable addition to the McGill Library collections since the majority of the books (58.6\%) constitutes unique holdings in Canada (see Table 2). It is necessary to acknowledge some limitations in the assessment of libraries' holding with use of AMICUS and the individual on-line catalogues, which are due to the existence of 'hidden collections' of uncatologued materials, mentioned earlier. However, at present, AMICUS, the Canadian national union catalogue, is the best available tool for the assessment of the frequency of the holdings in Canadian libraries. This survey can be repeated several years later when more collections that are presently 'hidden' and uncatalogued will be added in local on-line catalogues and, consequently, in AMICUS.

Table 2

\begin{tabular}{|l|l|l|}
\hline $\begin{array}{l}\text { Number of Holdings } \\
\text { Other than McGill }\end{array}$ & $\begin{array}{l}\text { No of } \\
\text { Titles }\end{array}$ & $\mathbf{\%}$ \\
\hline 0 libraries & 51 & 58.6 \\
\hline 1-3 libraries & 26 & 30 \\
\hline 4-6 libraries & 6 & 6.9 \\
\hline 6-10 libraries & 1 & 1.1 \\
\hline more than 10 libraries & 3 & 3.4 \\
\hline Total & 87 & 100 \\
\hline
\end{tabular}

Tables 3 and 4 below illustrate the relationship between languages and places of publication. The majority of the books (51.7\%) were published in continental Europe, which finds its reflection in the distribution of languages of publications because non-English (Latin, French, Italian, and Greek) books account for more than $50 \%$ of the collection. 
Table 3

\begin{tabular}{|l|l|l|}
\hline $\begin{array}{l}\text { Language of } \\
\text { Publication }\end{array}$ & $\begin{array}{l}\text { No of } \\
\text { Titles }\end{array}$ & $\mathbf{\%}$ \\
\hline English & 41 & 47.1 \\
\hline Latin & 32 & 36.8 \\
\hline French & 10 & 11.5 \\
\hline Italian & 2 & 2.3 \\
\hline Greek & 2 & 2.3 \\
\hline Total & 87 & 100 \\
\hline
\end{tabular}

Table 4

\begin{tabular}{|l|l|l|}
\hline $\begin{array}{l}\text { Place of } \\
\text { Publication }\end{array}$ & $\begin{array}{l}\text { No of } \\
\text { Titles }\end{array}$ & $\%$ \\
\hline Cont. Europe & 45 & 51.7 \\
\hline UK & 36 & 41.4 \\
\hline US & 6 & 6.9 \\
\hline Total & 87 & 100 \\
\hline
\end{tabular}

Finally, a subject analysis of the collection has been undertaken. Due to the small number of items in the collection, all titles have been grouped in seven wide subject categories largely corresponding to the subject areas of the Library of Congress Classification. The subject content of the collection is an excellent reflection of the professional and intellectual interests of its creator: a well-educated Anglican minister, known to read daily his Hebrew and Greek Bibles, "a lover of Art",40 and a collector of rare books. "Philosophy/ Religion" and "Literature" constitute almost half of his collection (see Table 5). Smaller but still significant proportions of the collection classified under "Geography, Exploration, Travel" and "Arts, Architecture, Design" represent other Mussen's important personal interests and pursuits. He was undoubtedly interested in traveling as he spent two years touring Europe, while his interest in architecture and design was even more important and practical. As it is mentioned above, Mussen was an amateur architect, who designed the complex of Saint-James the Apostle and Martyr Church in Farnham, included now in the Canadian Register of Historic Places and the Répertoire du patrimoine culturel du Québec (see Note 7). The exact match of the subject coverage of the collection with the proven interests, hobbies, and occupations of Mussen allows us to suppose that if a complete inventory of collection is ever discovered, the subject distribution will not significantly change.
Table 5

\begin{tabular}{|l|l|l|}
\hline $\begin{array}{l}\text { Subject } \\
\text { Group }\end{array}$ & $\begin{array}{l}\text { No of } \\
\text { Titles }\end{array}$ & $\mathbf{\%}$ \\
\hline $\begin{array}{l}\text { Philosophy, } \\
\text { Religion, Bibles }\end{array}$ & 24 & 27.7 \\
\hline Literature & 18 & 20.7 \\
\hline $\begin{array}{l}\text { Geography, } \\
\text { Exploration, Travel }\end{array}$ & 15 & 17.2 \\
\hline World History & 10 & 11.5 \\
\hline $\begin{array}{l}\text { Arts, Architecture, } \\
\text { Design }\end{array}$ & 9 & 10.3 \\
\hline Law & 6 & 6.9 \\
\hline $\begin{array}{l}\text { Science, Natural } \\
\text { Science }\end{array}$ & 5 & 5.7 \\
\hline Total & 87 & 100 \\
\hline
\end{tabular}

\section{VI}

At present, 112 Mussen prints housed at the McGill Library include 98 prints from the Mussen Memorial list and 14 prints not included in the list (see the discussion on the discovery of the collection in the Section III above). The collection comprises, among other items, the renowned Four Horseman of Apocalypse, Flight into Egypt, and Presentation in the Temple by Albrecht Durer; The Descent from the Cross, Portrait of Petrus van Tol, and Return of the Prodigal Son by Rembrandt; Prodigal Son by Sebald Beham; Sainte Madeleine by Lucas van Leyden; Christ with the Crown of Thorns by Van Dyck; and a number of prints by Lucas von Cranach, Cornelis Galle, Jacques Callot, and Hieronymus Cock. It must be noted that while it was not uncommon for collectors to purchase and collect prints cut out of early printed books, all Mussen's prints represent stand-alone items, produced and sold as separate prints. This provides another insight into Mussen's collecting practices and creates his image as of a scrupulous and conscientious prints collector.

A significant part of the collection (more than 90\%) consists of old master prints produced during the golden age of print-making, the $16^{\text {th }}$-the early $17^{\text {th }}$ centuries (see Table 6), which shows this was undoubtedly the period of Mussen's major collecting interest. 
Table 6

\begin{tabular}{|l|l|l|}
\hline Century & $\begin{array}{l}\text { No of } \\
\text { Prints }\end{array}$ & \% \\
\hline 16 th & 46 & 41 \\
\hline 17 th & 58 & 51.8 \\
\hline 18 th & 3 & 2.7 \\
\hline undefined & 5 & 4.5 \\
\hline Total & 112 & 100 \\
\hline
\end{tabular}

Mussen's collecting interest in earlier prints is also manifested in the proportional distribution of the schools of printmaking (see Table 7). The majority of prints (more than $60 \%$ of the collection) belong to the Northern schools, German and Dutch/Flemish, which were the most important in the early period of printmaking.

Table 7

\begin{tabular}{|l|l|l|}
\hline School & $\begin{array}{l}\text { No of } \\
\text { Prints }\end{array}$ & $\mathbf{\%}$ \\
\hline Dutch/ Flemish & 47 & 42 \\
\hline German & 21 & 18.8 \\
\hline French & 20 & 17.8 \\
\hline Italian & 19 & 16.9 \\
\hline Undefined & 5 & 4.5 \\
\hline Total & 112 & 100 \\
\hline
\end{tabular}

It is difficult to explain the small quantity of woodcuts in Mussen's collection (see Table 8). We could not attribute this small number to his lack of appreciation of this printmaking technique because the woodcuts present in his collection are of the uppermost value: of eight woodcuts four are of Albrech Durer and two of Lucas von Cranach. We can only speculate that the woodcuts might have been difficult to obtain or beyond his financial means.

Table 8

\begin{tabular}{|l|l|l|}
\hline Technique & $\begin{array}{l}\text { No of } \\
\text { Prints }\end{array}$ & $\mathbf{\%}$ \\
\hline Engraving & 74 & 66.1 \\
\hline Etching & 30 & 26.8 \\
\hline Woodcut & 8 & 7.1 \\
\hline Total & 112 & 100 \\
\hline
\end{tabular}

The subject matter of the prints collection, similarly to his book collection, reflects with striking accuracy the professional and intellectual interests of its former owner, an Anglican rector, interested in history with "Christianity, Bible" and "Ancient History/Mythology" constituting more than two thirds of his collection (see Table 9). The predominance of those subjects in the collection can also be attributed to his collecting interest in the old master prints, for which religion and ancient history and mythology were common subjects.

Table 9

\begin{tabular}{|l|l|l|}
\hline Subject & $\begin{array}{l}\text { No of } \\
\text { Prints }\end{array}$ & \% \\
\hline Christianity, Bible & 76 & 67.8 \\
\hline $\begin{array}{l}\text { Ancient History/ } \\
\text { Mythology }\end{array}$ & 18 & 16 \\
\hline Genre Scene & 7 & 6.3 \\
\hline Landscape & 5 & 4.5 \\
\hline Portrait & 5 & 4.5 \\
\hline Architectural Detail & 1 & 0.9 \\
\hline Total & 112 & 100 \\
\hline
\end{tabular}

\section{VII}

The process of discovering this collection leaves two questions unanswered. The first question is the size and content of the initial Mussen collection, i.e. its parts that were not donated or accepted in the McGill Library in 1919 or in 1941. Unfortunately, there is little probability that the rest of Mussen collection or its inventory can ever be discovered. Miss C.E. Mussen's estate was managed by the Crown Trust Company that failed in 1983. Its archives are not found either in Bibliothèque et Archives nationales du Québec (BAnQ) ${ }^{41}$ or in Library and Archives Canada ${ }^{42}$. It's possible that the papers of the Crown Trust Company may be held by the Canada Deposit Insurance Corporation, of which it was a member institution. ${ }^{43}$ However, even if located, the documents might not be made available for research due to the privacy concerns. Other probable sources of information could be either privately held papers or county archives. If further research on Mussen collection were undertaken, the next steps could include finding descendants of T.W. Mussen's nephew, Harold Beauford Mussen, son of William W. Mussen ${ }^{44}$ or the descendants of other branches of the Mussen family in addition to the known ones: Miss C.E. Mussen, daughter of the T.W. Mussen, who died childless in 1941; Henry S. Mussen, brother of T.W. Mussen, who died a bachelor in 1912; 45 and Alexander Mussen, another brother, who went to Australia to try his luck on the goldfields and to escape the consequences of some disreputable behaviour 
and who was killed in 1864 at Lower Pyramul unmarried and childless. ${ }^{46}$

Another research avenue might shed light on the second unanswered question: the process of acquisition of the collection (dates, places, and ways of purchasing: in person or through the booksellers, etc.). T.W. Mussen kept diaries for the most of his life, the excerpts of which, dealing with his professional activities including acquisition, building, and enlarging of the church property in Western Farnham, were published in Missisquoi County Historical Society Reports in $1965-1980^{47}$ as a series of articles "Cannon Mussen's Diary" by late G.P. Hawke. The diaries (from March 31, 1855 to March 18, 1856 and from Dec. 27. 1876 to Sept. 4 1885) are kept at the Brome County Historical Society archives. ${ }^{48}$ Taking into account the detailed style of his diary entries, it may be supposed that he could have also been recording information about the books and the prints that he was collecting. Therefore, his diaries might prove to be a valuable source of information about the origins of the collection.

The subject of reading and collecting habits of Canadians and Quebecers in the $18^{\text {th }}$ and $19^{\text {th }}$ centuries has been actively pursued and successfully explored by several researchers, such as Patricia Fleming, Yvan Lamonde, Marcel Lajenesse, Gilles Gallichan, and Sophie Montreuil, to name just a few. ${ }^{49}$ A reconstructed Mussen collection offers researchers in Canadian history and in the history of the book in Canada yet another insight into collecting pursuits and reading interests of educated Montrealers and Quebecers of the $19^{\text {th }}$ century. The knowledge of and the interest in early printed books and old master prints, and the ability of a Quebec rural clergyman to collect them, demonstrated by the existence of the Mussen collection, could contribute to our understanding of Canadian and Quebec cultural reality at the time.

Finally, it should be said that working on the Mussen collection has permitted the author of this article to understand and even connect with the personality and mind of the person who created it - a passionate, knowledgeable, and focused collector. This experience demonstrates again the truthfulness of the quote by Sir William Osler: "A library represents the mind of its collector, his fancies and foibles, his strength and weakness, his prejudices and preferences. Particularly is this the case if, to the character of a collector, he adds-or tries to add-the qualities of a student who wishes to know the books and the lives of the men who wrote them." 50

\section{Acknowledgments}

I am profoundly grateful to Dr. Richard E. Virr, Head and Curator of Manuscripts of McGill RBSC, for his advice and guidance through the project, as well as to Gordon Burr, Senior Archivist of McGill University Archives, for his support of this research. I would like also to thank my colleagues from McGill University, Megan Chellew, John Hobbins, Louisa
Piatti, and especially Professor Peter F. McNally for reading and commenting on the draft of this article.

\section{ENDNOTES}

${ }^{1}$ Barbara M. Jones, "Hidden Collections, Scholarly Barriers: Creating Access to Unprocessed Special Collections Materials in America's Research Libraries," RBM: A Journal of Rare Books, Manuscripts and Cultural Heritage 5, no. 2 (2004): 88-105.

${ }^{2}$ Melissa A. Hubbard and Ann K. D. Myers. "Bringing Rare Books to Light: The State of the Profession," RBM: A Journal of Rare Books, Manuscripts, and Cultural Heritage 11, no. 2 (2010): 134-51.

${ }^{3}$ Jones, "Hidden Collections, Scholarly Barriers: Creating Access to Unprocessed Special Collections Materials in America's Research Libraries," 88-105.

${ }^{4}$ Quarterly and Annual Report of the Librarian, 1917-1920. McGill University Archives, R.G. 40, c. 0033, file number 03307.

${ }^{5}$ Letter of 2 May 1941 to University Librarian G.R. Lomer from Crown Trust Company. Copy. Bequest of Mussen, Miss Caroline E. File. McGill University Archives, R.G. 40, c. 0233, file number 02650.

${ }^{6}$ William H. Atherton and Rodolphe Joubert, Montreal, 1535-1914 (Montreal: S. J. Clarke, 1914), v. 3, 209.

${ }^{7}$ More information about the complex of Saint-James the Apostle and Martyr Church can be found on the websites of the Canada's Historic Places http://historicplaces.ca/en/rep-reg/place-lieu.aspx?id=13275.

Répertoire du patrimoine culturel du Québec http://www.patrimoineculturel.gouv.qc.ca/rpcq/detail.do? methode $=$ consulter\&id=120972\&type =bien, and Ville de Farnham http://www.ville.farnham.qc.ca/culture.htm

${ }^{8}$ Douglas J. Borthwick, History of the Diocese of Montreal, 1850-1910 (Montreal: J. Lovell, 1910), 121. Head and Curator of Manuscripts of Rare Books and Special Collections, Dr. Richard E. Virr referred the author to this resource.

${ }^{9}$ Quarterly and Annual Report of the Librarian, 1917-1920.

${ }^{10}$ Borthwick, History of the Diocese of Montreal, 119. Later, he studied the Ministry at the Lennoxville University after spending two years at McGill.

11“Notable Gifts to M'Gill Library.” Montreal Gazette, 15 February 1919.

${ }^{12}$ Maria Lydia Brendel, "Not a Bad 'Impression': A Fine 'Rembrandt' Print in McGill's Collection," Fontanus 10, (1998): 35-40.

${ }^{13}$ Quarterly and Annual Report of the Librarian, 1917-1920.

${ }^{14}$ Richard Edmund Virr, Barbara Lawson, Michael Woloch, and Franziska E. Shlosser, "The McGill University Collection of Greek and Roman Coins: New Evidence for Its History," Fontanus 4, (1991): 109-24.

${ }^{15}$ Quarterly and Annual Report of the Librarian, 1917-1920.

${ }^{16}$ T.W. Mussen File, Rare Books and Special Collection, McGill University.

${ }^{17}$ Mussen Memorial list, T.W. Mussen File, Rare Books and Special Collection, McGill University.

${ }^{18}$ European Prints Catalogue, Rare Books and Special Collection, McGill University.

${ }^{19}$ Database of RKD (Rijksbureau voor Kunsthistorische Documentatie/ Netherlands Institute for Art History) http://website.rkd.nl/home.

${ }^{20}$ University Librarian Charles H. Gould Letterbooks, March 7, 1918 to May 2, 1919, McGill University Archives, R.G. 40, c. 0060, file number 01620.

${ }^{21}$ Letter of 31 January 1919 to Mrs. T.W. Mussen from University Librarian Charles H. Gould. Gould Letterbooks, McGill University Archives, R.G. 40 c. 0060, file number 01620. See also Letter of 10 February 1919 to Miss C.E. Mussen from University Librarian Charles H. Gould. Gould Letterbooks, McGill University Archives, R.G. 40 c. 0060, file number 01620.

${ }^{22}$ Letter of 31 January 1919 to Mrs. T.W. Mussen from University Librarian Charles H. Gould. 
${ }^{23}$ Letter of 10 February 1919 to Miss C.E. Mussen from University Librarian Charles H. Gould.

${ }^{24}$ "Notable Gifts to M'Gill Library."

${ }^{25}$ McGill University Annual Report of the Governors, Principal, and Fellows for the Year 1918-1919, Montreal: McGill University, 1919.

${ }^{26}$ Presentations to the Redpath Library June-1941, Rare Books and Special Collection, McGill University. [Draft]

${ }^{27}$ Annual Report of the University Librarian, 1941-1942, McGill University Archives, R.G. 40, c. 0026, file number 02579.

${ }^{28}$ Accession Registers 1941-1947, Rare Books and Special Collection, McGill University.

${ }^{29}$ Annual Report of the University Librarian, 1941-1942.

${ }^{30}$ Bequest of Mussen, Miss Caroline E. File, McGill University Archives, R.G. 40, c. 0233 , file number 02650.

${ }^{31}$ Letter of 2 May 1941 to University Librarian G.R. Lomer from Crown Trust Company.

${ }^{32}$ Ibid.

${ }^{33}$ Ibid.

${ }^{34}$ Ibid.

${ }^{35}$ Most of the Mussen's books not accepted by the McGill Library and donated to the Montreal Diocesan Theological College in 1941 might have ended up in the McGill Library collection when the College library was transferred to the McGill Library. However, those books cannot be located as their initial provenance had not been traced.

${ }^{36}$ Eight bound-together titles include 2 incunabula, 4 titles published in the 16 th century, and 2 titles published in the 17 th century.

${ }^{37}$ It must be taken into account that should the inventory of the whole collection is ever discovered and become available for analysis, the proportional distribution of places and dates of publication might change.

${ }^{38}$ AMICUS. http://www.collectionscanada.gc.ca/amicus/index-e.html

${ }^{39}$ See "Notable Gifts to M'Gill Library."

${ }^{40}$ Borthwick, History of the Diocese of Montreal, 121.

${ }^{41}$ E-mail communication from L'équipe de recherche de la Direction du Centre d'archives de Montréal et des archives privées, judiciaires et civiles to Svetlana Kochkina, September 23, 2011.
${ }^{42} \mathrm{E}$-mail communication from Ilene McKenna Reference Archivist, Reference Services /Service de référence Information and Research Services Division/ Division des services de l'information et de la recherche Library and Archives Canada / Bibliothèque et Archives Canada to Svetlana Kochkina, October 31, 2011.

${ }^{43}$ Canada Deposit Insurance Corporation. History of Member Institution Failures. http://www.cdic.ca/WhereInsured/FailureHistory/Pages/ default.aspx

${ }^{44}$ Atherton and Joubert, Montreal, 1535-1914, v. 3, 209.

${ }^{45}$ Letter of 2 May 1941 to University Librarian G.R. Lomer from Crown Trust Company. Atherton and Joubert, Montreal, 1535-1914, v. 3, 209.

${ }^{46}$ Peter Lane, Laina Hall, and Susannah Helman. "Stories of sadness and loss". Website of the National Museum of Australia. http://www.nma. gov.au/audio/transcripts/NMA_Hall_20090613.html. Letter from Samuel Bromley to Thomas Mussen, Jan 1867. Website of the National Museum of Australia. http://www.nma.gov.au/collections-search/ display?irn=128126. Collection of autograph letters and ephemera relating to the gold fields of New South Wales and the killing of Alexander Mussen by bushrangers. Christie's sale 4073/ lot $60 \mathrm{http}: / /$ www.christies.com/ LotFinder/lot_details.aspx?intObjectID $=4787229$.

${ }^{47}$ Report (Missisquoi County Historical Society), (Stanbridge East, Québec: Missisquoi County Historical Society, 1899-1913).

${ }^{48} \mathrm{E}$-mail communication from Arlene Royea, Managing Director of Brome County Historical Society to Svetlana Kochkina, May 26, 2011.

${ }^{49}$ Yvan Lamonde, Patricia Fleming, and American Antiquarian Society, Cultural Crossroads: Print and Reading in Eighteenth-and Nineteenth-Century Montreal (Worcester: American Antiquarian Society, 2004). Lamonde, Yvan, and Sophie Montreuil, Lire Au Québec Au XIXe Siècle (Saint-Laurent, Québec: Fides, 2003). Yvan Lamonde, Daniel Olivier, and Lawrence M. Lande, Les Bibliothèques Personnelles Au Québec: Inventaire Analytique Et Préliminaire Des Sources (Montréal: Ministère des affaires culturelles, Bibliothèque nationale du Québec, 1983). Marcel Lajeunesse, «Personal Libraries and Bibliophilia,» in History of the Book in Canada, ed. Fleming et al. (Toronto: University of Toronto Press, 2004), vol. 1, 202-206. Yvan Lamonde and Andrea Rotundo, "Entering Personal Libraries," in History of the Book in Canada, ed. Fleming et al., (Toronto: University of Toronto Press, 2004), vol. 2, 243-246.

${ }^{50}$ William Osler, Bibliotheca Osleriana: a Catalogue of Books Illustrating the History of Medicine and Science, (Montreal: McGill-Queen's University Press, 1969), xxvii. 


\title{
Régis Messac at McGill University, 1924-1929: \\ Fact and Fiction
}

\section{by Robert H. Michel}

\begin{abstract}
Régis Messac (1893-1945), French author of science fiction, satire and social criticism taught French at Montreal's McGill University from 1924 to 1929. A provocative thinker whose works are now being republished, his years at McGill inspired harsh criticism of American society and a satirical novel Smith Conundrum about the trials of teaching at a thinly disguised McGill. His satire is college fiction in the tradition of his fellow professor Stephen Leacock but harsher. This article reconstructs Messac's career at McGill, links his journalism during that time with his novel and traces how closely he used real people and events at McGill as inspirations for his satire. The article mainly draws on McGill's archival records, calendars, and student publications as well as Messac's own publications. ${ }^{1}$
\end{abstract}

\section{RESUMÉ}

Régis Messac (1893-1945), auteur français d’oeuvres de science fiction, de satire et de critique sociale, enseigna le français à l'Université McGill à Montréal de 1924 à 1929. Un penseur provocant dont les oeuvres sont aujourd'hui en réédition, ses années à McGill l’ont mené à critiquer sévèrement la société américaine et ont inspiré son roman Smith Conundrum qui traite des difficultés de l'enseignement à une Université McGill qui n’y est que très légèrement déguisée. Son oeuvre satirique de fiction collégiale est dans la tradition de son collègue, le professeur Stephen Leacock, mais est de nature plus sévère. Cet article reconstruit la carrière de Messac à McGill, établit des liens entre son journalisme et son roman durant cette époque, et examine la manière dont des gens et des événements à McGill lui ont servi de source d'inspiration directe pour son oeuvre satirique. L'article utilise principalement des documents d'archives, des calendriers et des publications étudiantes à McGill ainsi que les oeuvres publiées par Massac lui-même. ${ }^{1}$

\section{ASSISTANT PROFESSOR RÉGIS MESSAC}

\section{Messac and the McGill French Department}

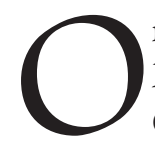
n 3 October 1924 a young French scholar, Régis Messac (1893-1945), answered the questions of Canadian immigration officials at Lacolle, Quebec. He was bound for Montreal, to McGill University, to teach French language and literature. Names? Régis Messac, age 30; accompanied by his wife Germaine, age 31, and sons Serge, age 3 years, Ralph, 25 days. They had arrived from France at New York on the S.S. De Grasse. The immigration questionnaires needed to be filled out three times: once typed by an official, once handwritten by Messac, and a third time, stamped "Guided," possibly indicating Messac needed prompting. On one form, he intends to stay three years, on another likely permanently. - Languages read? "English, French, Latin, Greek, German." - Religion? "Roman Catholic." - By whom passage ( $1^{\text {st }}$ class) paid? "French foreign office" [The French government assisted professors to teach abroad]. Messac had the equivalent of $\$ 175$ Canadian dollars. - Ever refused entry to or deported from Canada? "No." - Employer? "The McGill University." - Are you or any of your family mentally defective? "No." - Tubercular? "No." - Physically defective? "No." Messac may have suppressed sarcastic replies. Somehow the refilling of forms conveys his uneasiness with bureaucracy - prophetic of his reactions to McGill and later in the French educational system. The officials could not have guessed that they were admitting quietly subversive free thinkers to the conservative, largely Catholic province of Quebec (Fig. 1). In 1917 Messac had met Germaine Desvachez, who had left home at 17, traveled in Eastern Europe, and become governess in a Russian family. Régis and Germaine had been living en union libre when their first son Serge was born (28 Oct. 1921) and only married in 1922 after Régis received his agrégation dans l'ordre de la grammaire, as it would have been impossible for him to take up his first teaching post unless they conformed to the conventions. ${ }^{3}$

This article detects the realities behind Messac's satire about McGill University, Smith Conundrum and reconstructs his life at McGill from the "real-life" evidence of the University's archives and the "fictional" evidence of his autobiographical novel. What did Messac do in his unknown formative years at McGill from 1924 to 1929 ? What lay behind his novel? His main concern at McGill was the completion of his doctoral thesis for the Sorbonne, the first scholarly study of detective 
fiction: Le 'Detective Novel' (published 1929). Messac is best known for his science fiction dystopias Quinzinzinzili (1935), La Cité des asphyxiés (1937) and Valcrétin (posthumously, 1973). He has been rediscovered and republished. Many inédits - essays, novels, and letters are being published for the first time, opening a new window on the tormented decades between the World Wars. ${ }^{4}$ The Société des amis de Régis Messac publishes a journal, Quinzinzinzili: l'univers messacquien and a collection of studies, Régis Messac: un écrivain journaliste à reconnaitre appeared in 2011. Examined here are 1) Messac's teaching of French at McGill, 1924-1929, and 2) Messac's satirical autobiographical novel about his alter ego André Pluche's teaching French at Smith Conundrum University the same years. So many of the novel's characters and episodes resemble real life professors and events that one is tempted to read the novel as a memoir or roman à clef. But it is also a roman à thèse: Smith Conundrum University is mediocre. Though it is disguised as an American university, we recognize a negative, surreal version of McGill. The novel targeted students indifferent to learning; pompous, incompetent professors; snobbery; religion; Prohibition, Puritanism, militarism, and American-style quantitative

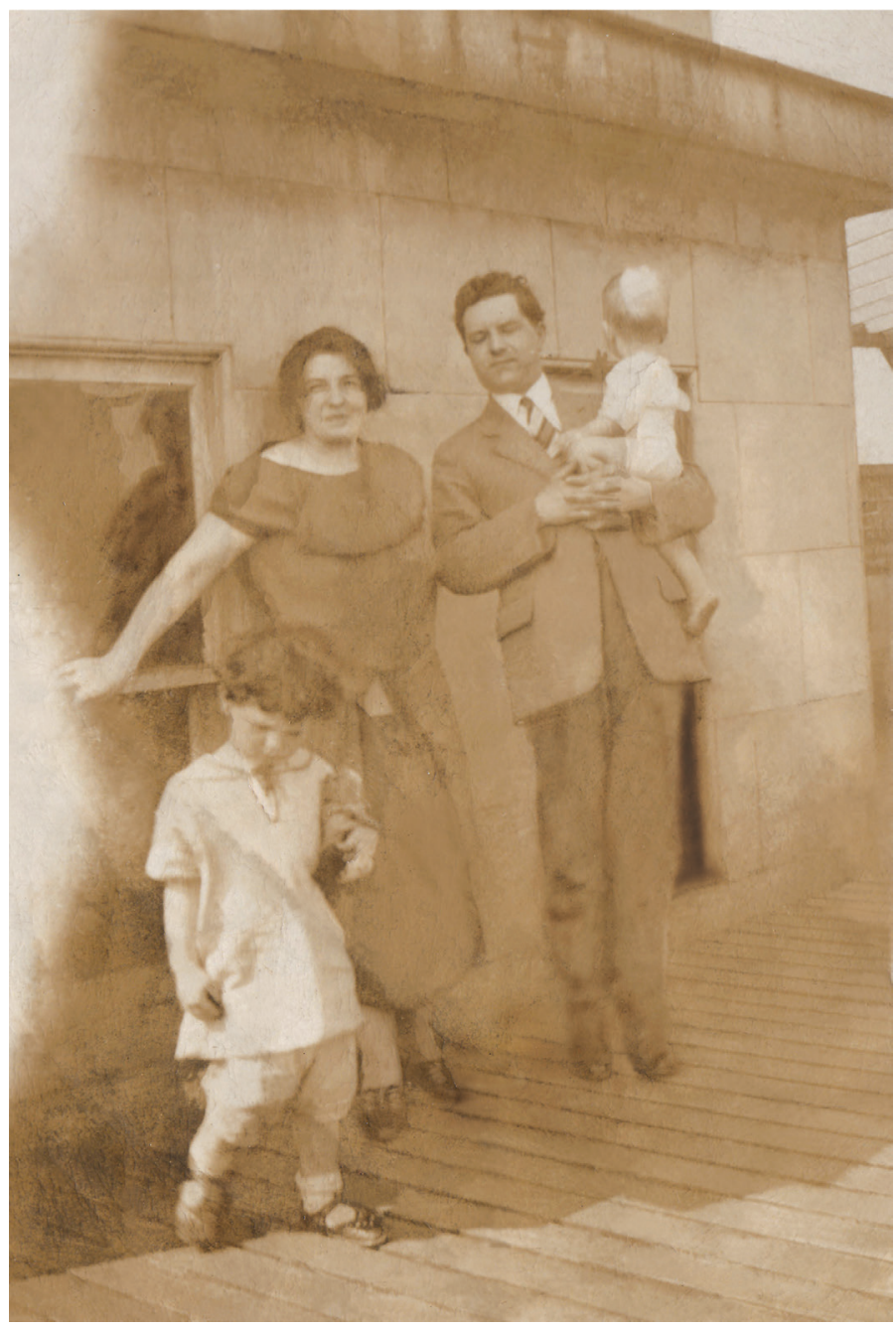

Figure 1. The Messac family in Montreal, ca. 1925, photographer unknown, courtesy O. Messac, Paris research. Very little has been written about Messac's five years at McGill yet they were pivotal to his development as a novelist and social critic. Likewise the connections between Smith Conundrum and Messac's career at McGill have never been fully explored. First, his career at McGill.

Born in France in 1893 to parents who were teachers, Messac was wounded early in the First World War and learned English working with British soldiers at Dunkirk docks. In 1922 he began to work on a doctoral thesis on the origins of the detective novel. It would be the first scholarly analysis of popular literature. His supervisor was Sorbonne professor Fernand Baldensperger, co-founder with Paul Hazard of the study of comparative literature. The detective novel had made its mark largely in English. To immerse himself in English while doing his research, Messac placed himself at the disposition of the French ministry of foreign affairs to teach abroad - first at University of Glasgow, where he was appointed for 1923-1924 to replace a staff member on sick leave, ${ }^{6}$ and then McGill University in Montreal from 1924 to 1929. One of McGill's attractions was its library. Messac used it heavily to research Poe and other authors for his thesis. When Messac arrived in October 1924, McGill had become Canada's best-known university, with a typical urban North American campus (Fig. 2). McGill was English-speaking, its attraction bolstered by the vibrant city of Montreal (population 750,000, 60\% French speaking). McGill had 3000 students, including 350 women. Unlike European universities, McGill was largely funded by private endowments and philanthropy from capitalists, including sugar refiner Peter Redpath, tobacco manufacturer Sir William Macdonald and railway magnate Lord Strathcona. Consequently, McGill was partly ruled and financially underwritten not by government but by its Board of Governors. Nearly all were businessmen; the Chancellor, Sir Edward Beatty, was the chairman of the Canadian Pacific Railway. [Messsac would find McGill, like Montreal, dominated by the commercial spirit, its staff, the lower ranks at least, little better off than the Governors' chauffeurs.] Students, however, enjoyed great freedom, access to English and French culture, drank alcohol (no Prohibition in Quebec), and attended mixed "co-ed" classes. We will see that Messac was struck by the wealth and racial and religious diversity of McGill. Some students came from Montreal's rich families, mainly of Scottish and English descent; most were middle class, drawn mainly from anglophone Montreal but also from the rest of Canada, the United States, and Britain. Students entered at age 17 or 18 , studied for 4 years or more in Arts, Science, Commerce, Engineering, Medicine, Law, Pharmacology, Nursing, etc. Tuition, board, lodging and other expenses came to around $\$ 600$ (bare minimum for Arts) to $\$ 1,000$ Canadian dollars per year. ${ }^{8}$

Messac might never have come to McGill if a violent dispute had not led to the creation of a separate, slightly expanded French department. In 1921 Swiss-born Professor Hermann Walter, ${ }^{9}$ Chairman of the Modern Languages Department, 
who taught German, accused Assistant Professor Joseph L. Morin, ${ }^{10}$ who taught French in the same department, of poisoning the well of his country house. This led to acquittals, suits and countersuits between Walter and Morin dragging on from 1921 to 1924 and later. The Principal, Sir Arthur Currie, and the Governors feared McGill's reputation would suffer because of the conflict. Currie suspended Walter and Morin, then reinstated Walter, then suspended him again. The archival record shows the fluctuation and backtracking of university governance. ${ }^{11}$ For a while, Currie seemed to favor Morin but the case was inconclusive. By 1922 Currie had decided the Department should be re-organized and by 1923 the 68 year-old Morin was forced to retire and Modern Languages was split into a Germanic Languages Department headed by Walter and a Romance Languages Department headed by French-born René du Roure. ${ }^{12}$ Due to a bias against the Quebec French accent, Morin was probably the last French Canadian on the fulltime French Department teaching staff until the 1960s. Du Roure and McGill's administrators preferred teachers born in France or at least in Europe. ${ }^{13}$

Morin's retirement made way for new appointments, first of André J. Roche in 1923 as Lecturer, then Messac by early July 1924 at the higher level of Assistant Professor. Messac had testimonials from his Agrégation examiners: Professor René Durand praised Messac's precision, clarity of expression and composition, while Professor Fèlix Gaiffe noted Messac had received the highest mark at his examination, that his teaching was excellent, and that any foreign university would find him an excellent professor. ${ }^{14}$ Messac's chairman at Glasgow, 1923-1924, Charles A. Martin, warmly recommended him, praising his teaching at upper levels: Messac had delivered

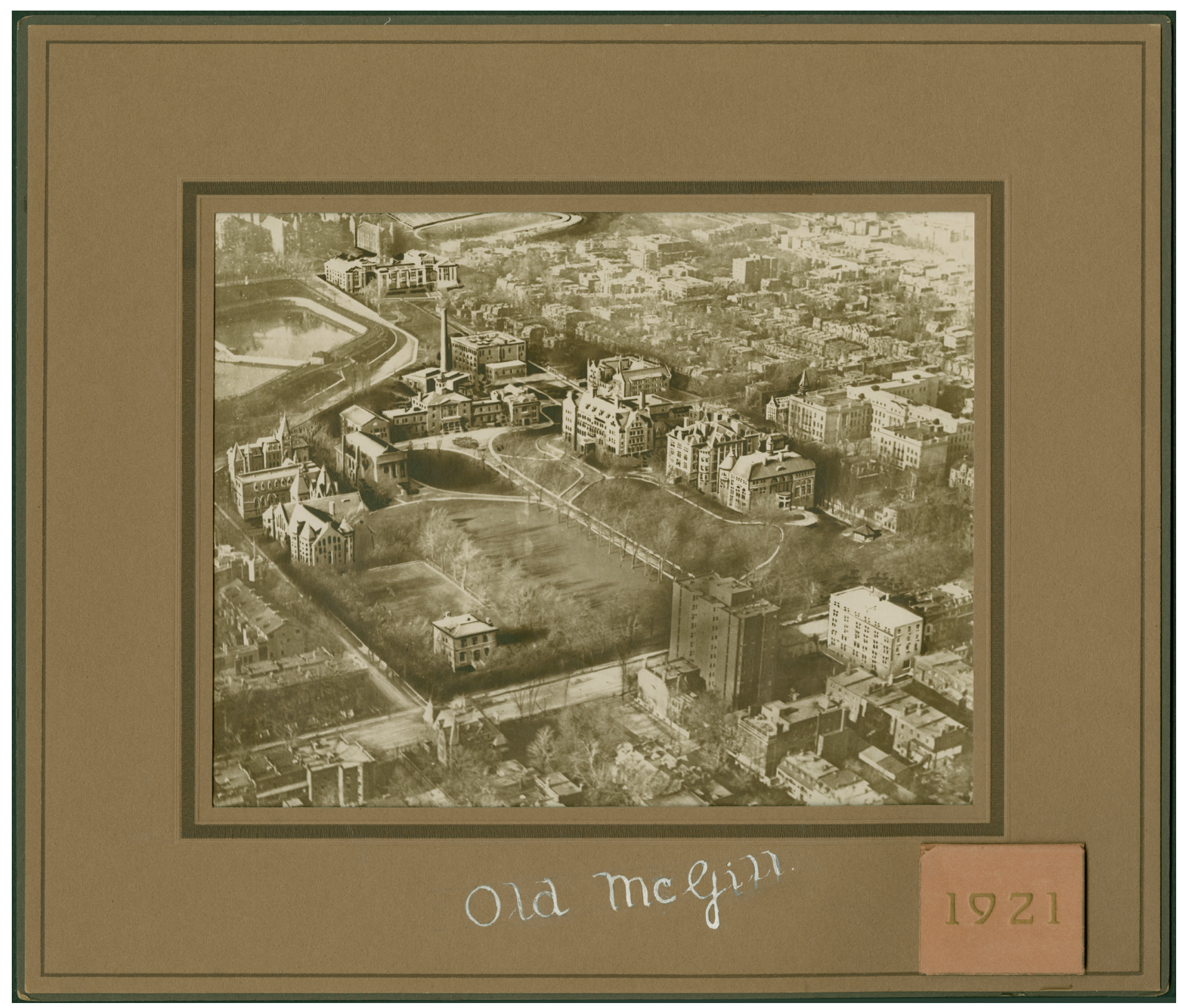


courses of lectures on the history of the French language and on French literature to students preparing for the M.A. Degree. He also taught 150 second year students in tutorial classes. "Monsieur Messac has a very keen sense of the value of the 'nuances' of expression in French, and is able to explain French Classical Texts, and also old French Texts, in a lucid, interesting, scholarly and profitable manner. I always found Monsieur Messac most conscientious, zealous, punctual and obliging, and I know that his work with the students has been very helpful to them indeed. He is a very kind \& devoted colleague." 15

The McGill student body was expanding and French courses were in high demand. McGill's small French Department prided itself on teaching entirely in French and offering a French environment in Montreal. It faced large classes (in the Arts Building, Fig. 3). Classes of 30 students were considered large and some had over 50, as McGill statistics and Messac's novel both testify. Messac with four or five others taught introductory and advanced language and literature courses. He was often paired with the department head du Roure, an indication of his importance. Courses and content varied by year; the following summarizes Messac's teaching. Messac and others, including du Roure, taught French Language First Year-three one hour lectures per week. The course included composition, French history texts, Dumas, Racine, Merimee, and Moliere's Le Bourgeois Gentilhomme. Similarly, Messac with others taught sections of Second Year language and literature courses; included were a variety of works such as Moliere's Les précieuses ridicules, Émile Augier, Le Gendre de M. Poirier, La Fontaine, Fables, as well as the recent romance about rural Quebec, Louis Hémon's Marie Chapdelaine. In 1926-1927 Messac taught fourth year students earlier $19^{\text {th }}$. century French literature, including Chateabriand and Balzac, and (presumably for translations) the recent best seller of du Roure's friend Stephen Leacock, My Discovery of England (1922). Other French courses also used My Discovery. With du Roure Messac taught Gil Blas, selections from Rousseau

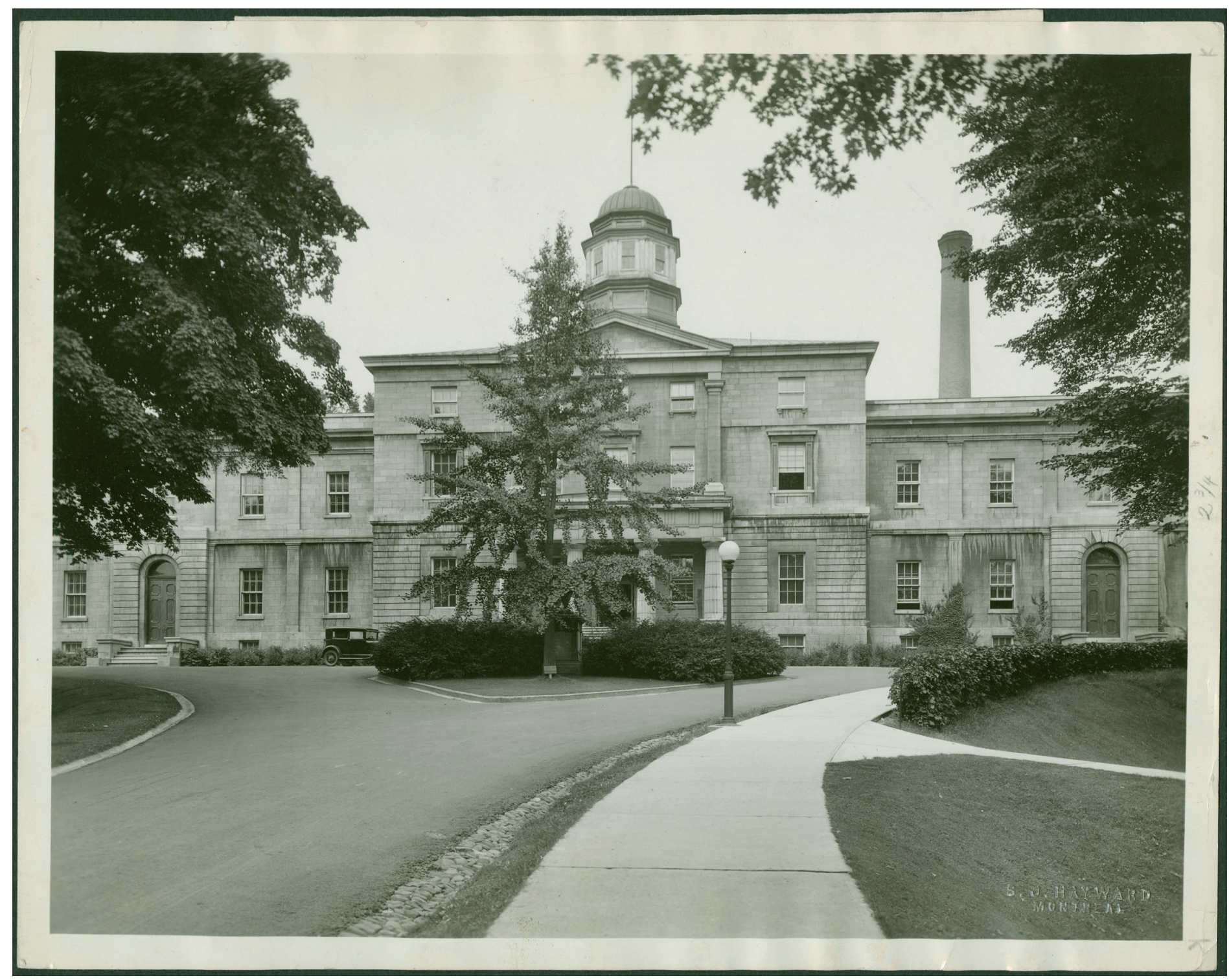

Figure 3. Arts Building, 1929, photographer S.J. Hayward, MUA PR026608 
and Voltaire, Beaumarchais, Hugo, Hernani; Balzac, and le père Goriot. Messac collaborated with du Roure (who loved staging theatre) in the course on $19^{\text {th }}$ century French theatre for honours and graduate students. Yet again paired with du Roure, he gave the honours course on the Evolution of the French Lyric. With Lucie Touren Furness, Messac taught later $19^{\text {th }}$ and $20^{\text {th }}$ century French literature, including Flaubert, Maupassant and Anatole France. In 1928-1929 with Lecturer Jeanne Durand-Joly, Messac taught French literature of the $17^{\text {th }}$ and $18^{\text {th }}$ centuries, including Racine's Phèdre. He would immortalize his attempt to teach Phèdre in his novel. As du Roure appreciated Messac's abilities, Messac's responsibilities and teaching levels increased. By 1926-1927 Messac had joined Touren Furness as an Associate of the Graduate Studies Faculty (du Roure was a full member) and in giving courses for graduate Master of Arts students. The French M.A. program included an English course in Comparative Literature, taught in alternate years by young English Department Assistant Professors Algy Noad and Harold Files, with whom Messac must have had interests in common. Noad was interested in utopias and his teaching and research notes briefly cite Messac on Poe; ${ }^{16}$ neither man appears to have inspired characters in Smith Conundrum. At the graduate level Messac taught Méthodologie (mandatory for the degree). He also taught an honours course on Balzac; this course and the History of Theatre given with du Roure were also offered as options to graduate students. ${ }^{17}$

Most French professors lectured 12 or 13 hours per week. Every year more students took French. In Fall 1926 there were five class sections with over fifty students and du Roure requested a temporary lecturer for the session, warning he would soon need a graduate student to give supplementary lectures to the "backward students" taking first year French. ${ }^{18}$ We will see the backward students in the novel-as well as the piles of examinations to mark. By Fall 1927 the situation was no better. Nothing was done. The conditions Messac would satirize were endemic to many universities: classes too large, not enough staff, and no help from the deans, who pleaded insufficient funds. McGill was strongest in medicine and the sciences. The higher administrators saw the French Department as worthy but mediocre with no stars such as Leacock. Messac might have become a star but left too soon. $\mathrm{Du}$ Roure was a good teacher but not a published scholar; he had dashing style but little clout as department head. A report by Dean of Arts Ira MacKay written just after Messac left McGill in 1929 sums up the state of the French Department and its methods:

The staff of this department is distinctly miscellaneous. Nevertheless it is doing good work. The standards in the French language are much higher than in any other of the Universities of the English-speaking Provinces.... French is the language of instruction in all classes. Not a word of English is spoken except to a small special group of students in the first year coming from wholly English-speaking communities. Half the students in the College [mainly Arts students] can read French, and 500 can listen to a lecture or play in French and understand it fully. ${ }^{19}$

\section{La civilisation américaine}

Messac's writing at McGill was prodigious. His greatest concern was his thesis; his novel's alter ego Pluche is similarly obsessed. At McGill, Messac (with Germaine's help) did most of the research and writing of the 698 page $\mathrm{Ph} . \mathrm{D}$. thesis Le 'Detective Novel' (published 1929, republished 2011); its foreword is dated 31 October 1928 at Montreal. ${ }^{20} \mathrm{He}$ also published an autobiographical anti-war novel Le Voyage de Néania in 1926. ${ }^{21}$ During his McGill years he published articles in scholarly journals on Bulwer-Lytton \& Dostoyevsky, Fenimore Cooper, Voyages modernes au centre de la terre, and Déterminisme et histoire littéraire. ${ }^{22}$ To cite an example of his close research on the origins of the detective novel (mainly in the $18^{\text {th }}$ and $19^{\text {th }}$ centuries), Messac corresponded in 1927 1928 with the librarians of West Point and of the University of Virginia about books by Voltaire and others which he thought Edgar Allan Poe might have borrowed to read while a student there. ${ }^{23}$ Messac's supplementary thesis was on French influences on Poe, and Poe of course was a major subject of Le 'Detective Novel.' Writing to the Poe scholar, Thomas Mabbott in 1928, Messac cited the complexities of hunting for Poe's French influences and indicated Baldensperger had thrust this supplementary topic on him after rejecting alternatives. ${ }^{24}$ Le 'Detective Novel' remains a classic authority on the origins of the genre; the crime novelist P.D. James cited it recently in her Talking About Detective Fiction (2009). ${ }^{25}$

The writings of Messac from his McGill period that are most akin to his novel are not his academic writings but his social criticism of America, in articles published from 1925 onward in Le Progrès civique, a leftist Paris journal. They recently have been examined by Astrid Llado. ${ }^{26}$ Pierre-Gilles Pélissier traces the seeds of Messac's science fiction novels of the 1930 s to his journalism. ${ }^{27}$ One may argue similarly that Smith Conundrum originated in Messac's analyses of America written while he was at McGill; indeed, he published the chapters of his novel of an "American" university alongside his American journalism in Le Progrès civique. Emphasized here are those articles which related to his views on university education or which show preoccupations similar to those in Smith Conundrum. He penned them from his perch in Montreal where he could read the American press and where attitudes reflected the American culture next door. ${ }^{28}$ After the First World War, French readers became fascinated by the swelling wealth, power and influence of the United States. Messac focused on America in his articles for the same reasons that he would make Smith Conundrum University 
American - he and his French readers were interested in the United States not Canada or Quebec.

A harsh, modern de Tocqueville, Messac decried America's materialism, conformity, primitivistic influence on Europe, mistreatment of Negroes, religious fundamentalism, Prohibition (his essay on Prohibition set off a controversy), tabloid sensationalism, fraudulent psychiatry, eugenics theories, and the failings of Christian Science (more controversy). His attacks were so fierce that French nationals living in America protested. ${ }^{29}$ Messac (and the journal's other writers, who included George Orwell) attacked war-mongering, religious and sexual puritanism, racism, nationalism, colonialism and capitalism. To readers 80 years later, Messac's opinions expressed in Le Progrès civique seem presciently modern and on the humane side of issues which still plague the world today. Astrid Llado argues that Messac did not intend to compare America unfavorably to France so much as against an ideal society toward which all who shared the journal's ideal of social improvement strove. ${ }^{30}$

In his first article for Le Progrès civique, in November 1925, Messac focused on American workers' desires to own cars and how they were duped by salesmen who got people to buy cars they could not afford on the instalment plan; he knew a janitor whose salary went to monthly payments for car, furniture, and electric washing machines. ${ }^{31}$ Weeks later, he ridiculed the flourishing (American) Ku Klux Klan and its ponderous hierarchy, ceremonies and its tarring and feathering of Blacks, anarchists and socialists. But fairly he concluded that France-the most individualist nation on earth-had also yielded to collective hysteria (probably referring to the Dreyfus Affair). ${ }^{32}$ In March 1926, from "wet" Quebec, Messac dissected America's Prohibition, pointing out a majority had banned alcohol; now a majority swilled it illegally. He suggested that Americans, maybe all AngloSaxons, found the thrill in drunkenness that Latins found in concupiscence. ${ }^{33}$ Responding to readers' criticism, he countered that alcohol gave the poor an escape; he recalled seeing the gaunt poor of Glasgow and understood why they drank whisky. Alcohol gave them a substitute for everything they lacked: joy, light, warmth, clean lodgings, etc. It would be criminal to take alcohol away without improving their social conditions. Hypocritical religion and the clergy were largely to blame for prohibition! ${ }^{34}$

In January 1926 Messac ridiculed American immigration rules with their "scientific" tests for admissibility and the barrage of personal questions which were pervaded by political, racial and eugenic fears. ${ }^{35}$ One must swear that one was not a Bolshevik, anarchist, nor a polygamist. [Leacock had made the same points in My Discovery of England (1922). ${ }^{36}$ ] Likewise one must not be syphilitic or tubercular. He also noted U.S. immigration authorities were tough on Jews. As well immigrants had to pass an intelligence test. Messac saw these tests as attempts to disqualify immigrant hordes and preserve the ideals of America's puritan pioneers and the positions of their descendants. However, the test's questions were so stupidly phrased that they hinted at the answers required. ${ }^{37}$ Here and later in Smith Conundrum, we see Messac's attitudes toward testing; he derided America's naïve belief in standardized intelligence tests such as Binet's and the obsession with "scientific" measurement and efficiency-now seducing admirers in France. Moreover, as he could read in the McGill Daily, American universities were introducing intelligence and psychological tests for admissions and other purposes. ${ }^{38}$

In April 1926 McGill held a special ceremony conferring honorary degrees on a French and a British dignitary. The episode demonstrates perfectly how Messac reacted to actual events and used them in both his journalism and his McGill novel; he rushed into print in Le Progrès civique a few weeks later with his strongest attack on American universities and used the degree ceremony for one of the most caustic chapters of Smith Conundrum (discussed later). In August 1926 Messac decried Jim Crowism and lynchings yet suggested America might prove a favorable place for the future of Blacks, prophetically, as Astrid Llado points out, with Barack Obama's winning the Presidency. ${ }^{39}$ Next Messac fired at fundamentalist religion, describing a church service he said he attended in New York on 1 August 1926. The congregation swayed, the preacher waved his arms and cried "Religion is a light!" Messac hears it as: "Religion is a lie." ${ }^{40}$ American material culture was as bad as its bogus religion: in January 1927 Messac wrote on American hygiene-he ranged from dirty hotel bathrooms to Americans' love of wearing huge round glasses and gold teeth. Apartments were overheated and undersized, furniture mass produced and ugly, and cuisine of the "quick-lunch-bar" horrible. ${ }^{41}$ His novel would rail against overheated offices and the mashed potatoes at the Faculty Club. Next he wrote on Herman Melville-perhaps an off-shoot of research for his thesis, which referred to Melville's Confidence Man. ${ }^{42}$

In April 1927 he reported on how Americans viewed Anatole France. ${ }^{43}$ The article resulted directly from his research and teaching; France appeared in both his thesis and his courses. In July 1927, as a pioneering student of popular literature, he praised American tabloids-not for their lurid stories about love and murder but for their short spicy language, catchy headlines, and frequent change of tone and typesets. ${ }^{44}$ In August 1927 he argued that single women had more freedom in America than Europe-no need to be part of a household. But he thought both single and married women wasted their time playing tennis, going to clubs and charitable societies. In passing, he noted Americans avoid unpleasant subjects by telling funny anecdotes. Humour is the accomplice of hypocrisy, he declared, possibly thinking of the affectionate college satires of Leacock or the clumsy jocular columns in the McGill Daily. Perhaps criticizing subjects like the lighter ones he heard debated by the Cercle Français at McGill, he ridiculed debating clubs which avoided troubling 
social issues in favour of such questions as "Should there be marriage bureaus in Universities?" and "Can a woman with cropped hair make a good housewife?" ${ }^{45}$ In one of his more provocative articles (December 1927), he attacked American Christian Science and its avoidance of medicine, evoking an angry rebuttal. ${ }^{46}$

Messac gravitated to the writings of Sinclair Lewis (author of Babbit, 1922) and Upton Sinclair who stridently voiced and probably helped shape Messac's own distrust of American middle class and business culture. Writing in 1926 Messac had defined Americans as Sinclair Lewis's archetype Babbit-conformists with their eyes on profit, who saw studying poetry, French and other subjects at university as a waste of time which would never earn a cent. ${ }^{47}$ Perhaps he was thinking of some of his students. Since he was writing for French readers, Messac may be forgiven perhaps for harping on the Babbit middle class stereotypes; they already were being fiercely attacked by American writers in the 1920s. Upton Sinclair, like Messac, promoted his social views in both fictional and nonfictional writing. In April 1928 Messac aired Upton Sinclair's arguments that literature and art usually served as propaganda for causes and that American writers were slaves to plutocracy. ${ }^{48}$ If Messac read Sinclair's Goose-step (1923), he must have approved of its fierce indictment of American universities for serving the moneyed establishment and for promoting sports to attract alumni donations. McGill and other universities in the mid-1920s debated whether sport was over-emphasized to help raise funds from alumni. In similar vein, the McGill student Cercle Français, in which Messac took part actively, had debated the effects of professionalization of sport in November 1926. In Le Progrès civique in August 1928 Messac, probably stirred by that ongoing debate, criticized America's obsession with professional sports, which instead of fostering public health focused on individuals and breaking records. He ridiculed sports idols with infantile brains-like Harry Swellhead, whom we will meet in Smith Conundrum. Declaring that Yale made $\$ 800,000$ each year on its football team, Messac charged in both this article and his McGill novel that the star athlete has the university at his feet. No need to take exams, he is passed in advance. How would a professor dare fail an athlete? He knows he will be broken if he tries. Everyone knows that the coach (perhaps thinking of McGill's admired football coach Frank Shaughnessy) is a more considerable figure and paid more than any professor. ${ }^{49}$ In July 1928 Messac wrote on revolutions: they are not just barricades and red flags but a redressing of justice, an excremental purging and redistribution of wealth for which even America may be ripe someday. ${ }^{50}$ His last article for Le Progrès civique to be written from McGill (December 1928) was about possible war between America and Japan for economic and military control of the Pacific. His discussion of economic, military and moral issues was informed, prophetic and distrustful of militarism among politicians and the blind public. ${ }^{51}$

\section{Quebec in Retrospect}

Messac wrote about the United States although he did not live there. What about Quebec, where he did live? Little evidence of the Messacs' daily lives survives except their rented homes. In Montreal, the Messacs lived first in a modest apartment building on downtown lower Rue St-Denis, next in attractive residential areas: a triplex on Blvd. St-Joseph, and lastly on Rue Molson opposite a park. ${ }^{52}$ We can safely assume Messac knew many McGill staff members, including those parodied in Smith Conundrum. He certainly knew his fellow instructor in the McGill French Summer School, French-born Marie Le Franc. Reviewing Le Franc's Au pays Canadien-français in 1932, he admitted she was a great lyrical poet and had lived in Canada longer than he but he could not recognize the Quebec she described. She ignored what Messac noticed most, the crooked politicians and the priests with their air of feudal lords. Perhaps her publishers wanted to please French Canadians; lightheartedly he concludes: Well, all travelers are liars.... ${ }^{53}$

In June 1935 his "Histoires Canadiens" in L'Idée Libre gave two very uncomplimentary vignettes of Quebec's Catholic clergy. He recalled the Laurier-Palace movie theatre fire of Sunday 9 January 1927 in Montreal East in which 78 children, French-Canadian Catholics, were suffocated trying to escape a fire. The Catholic clergy, he said, had called it the vengeance of God on Montreal's sins and it inspired a popular lament: that God had needed angels for paradise. Fortunate children, commented Messac, to proceed directly to heaven and expiate the sins of their elders! More personal, Messac related his wife Germaine's brush with the Catholic clergy. For two years, they had lived on Blvd. Saint-Joseph Est opposite église Saint-Pierre-Claver, named for a Jesuit missionary (1580-1654) - who was eaten by "les sauvages," Messac claimed gleefully but erroneously. The church had a small park where Germaine would take the children to play (Fig. 4). Inevitably, one day the vicar, Zacharie Picotte, approached her. [Messac does not mention that Picotte, born 1872, had recently published a book about Pierre Claver. ${ }^{54}$ ] -Are these little angels yours? he asked. Yes, she replied. Then they will soon be old enough for catechism. No, their father would never consent! -Would not consent! But do you realize the little cherubs will roast in hell? He described hell's torments imaginatively. Germaine finally cut him short: Useless, Monsieur le Curé. In fact, I should tell you we are married civilly. An even greater shock to the priest. -Madame, savez-vous que vous êtes en état de concubinage! $\mathrm{He}$ offered to marry them in church. My husband would never consent, replied Germaine. Upon which (while Régis obliviously read his English authors across the street in their apartment), the priest offered Germaine what Régis, knowing the audacity of Quebec priests, at first thought must be a fraud: the priest could marry her in the church, without Régis's knowing, through the ceremony of sanatio in radice, in which she alone need give her consent. Later Messac checked 


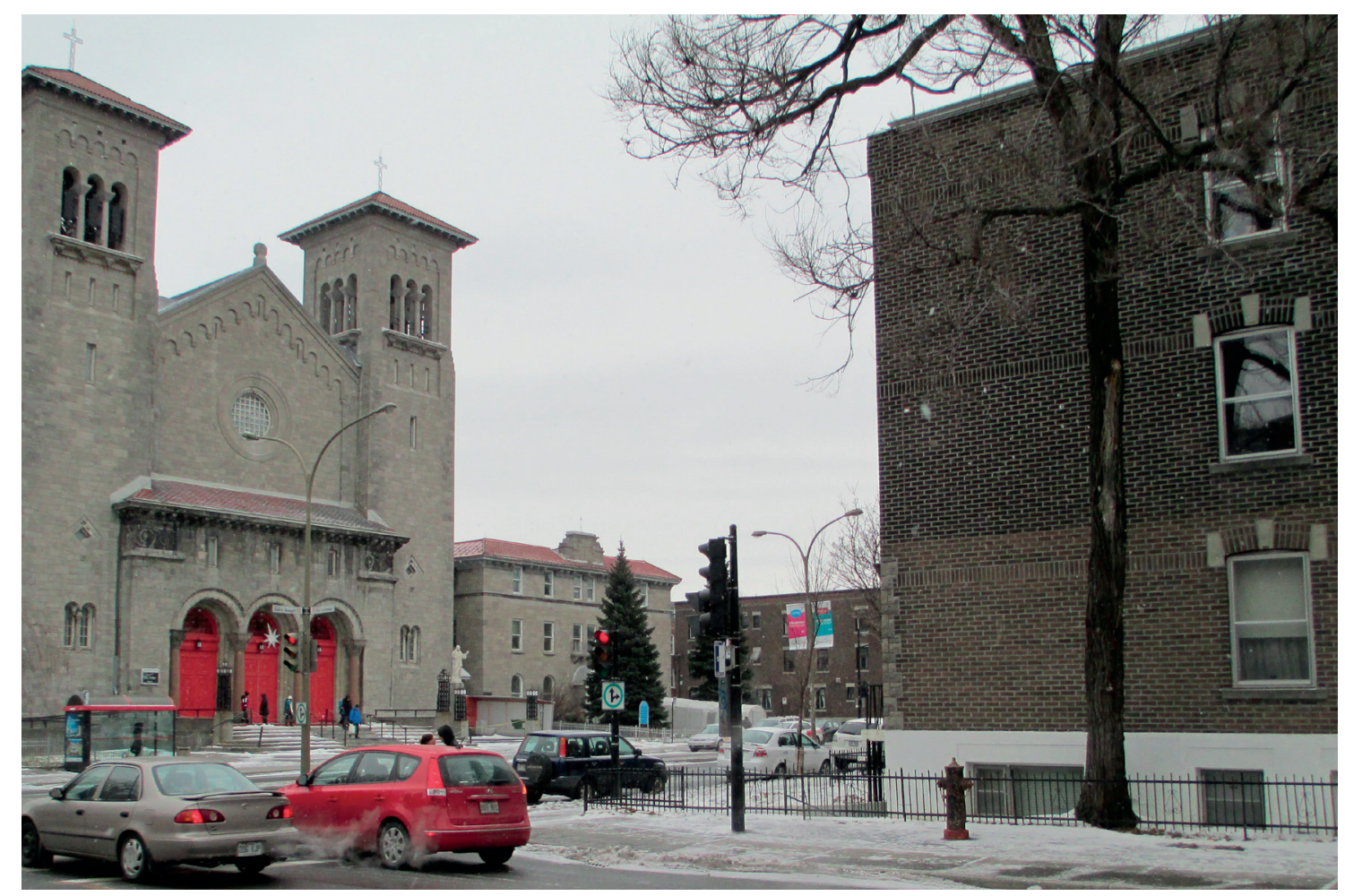

Figure 4. Messac apartment (R), 2045 St-Joseph E., Montreal, opposite Église St-Pierre-Claver, photographer Robert Michel, 2012

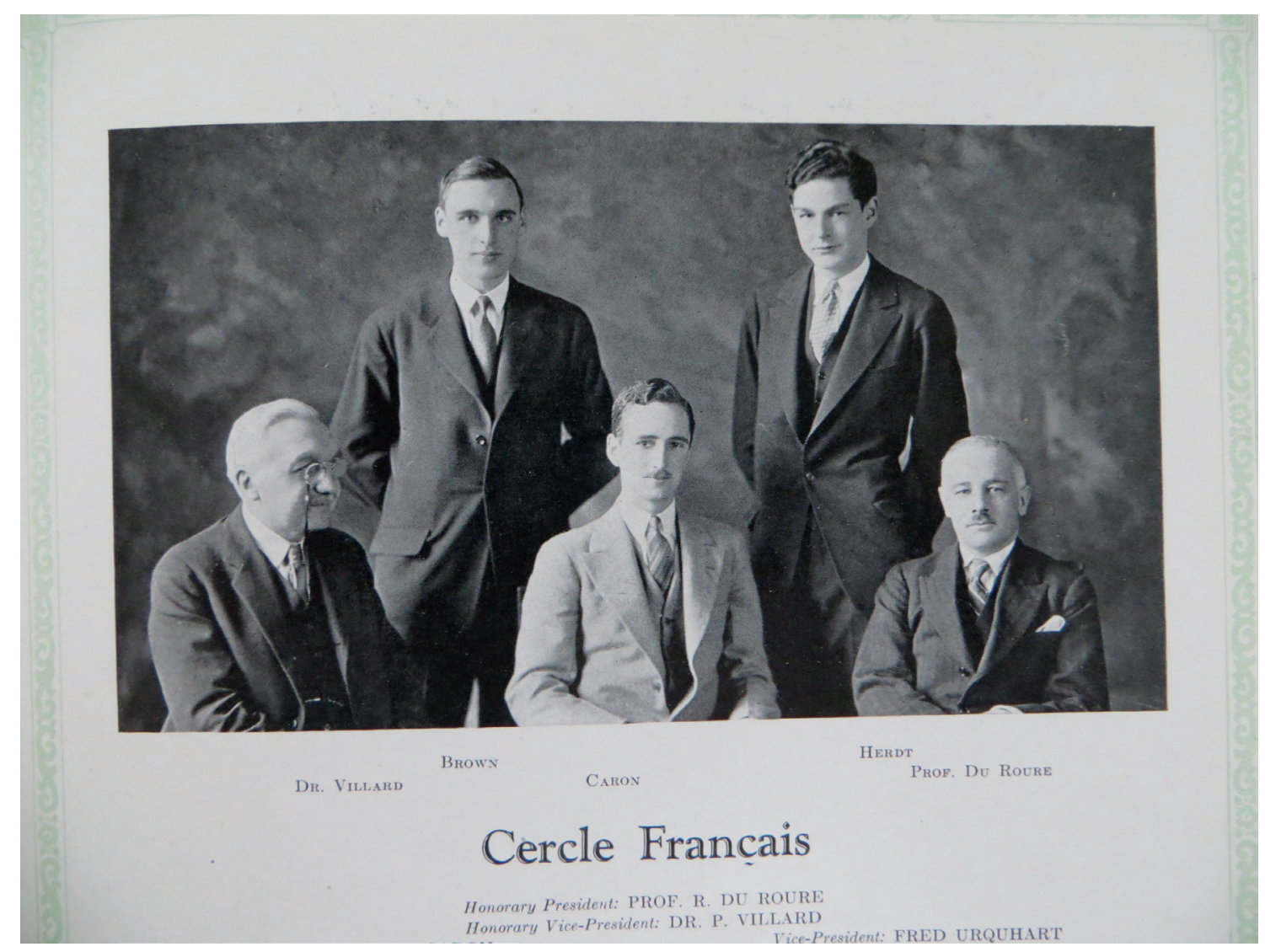

Figure 5. Le Cercle Français: Villard (L), du Roure (R), and student officers, Old McGill 1929, 203 
with a knowledgeable friend who said the form really existed. As Germaine left, the priest cried: -Reflect (adding what Messac declared showed his real motives): for you, my child, it will cost only sixty dollars! $!^{55}$ While Ralph Messac would have been only two or so, Serge Messac would have been perhaps five. According to Ralph's son Olivier Messac, the older boy was not sent to school during the family's sojourn in Montreal because Régis did not wish him to be exposed to the teaching of the Catholic clergy who ran the francophone schools. ${ }^{56}$ This rare glimpse of Messac's life in Montreal reflects his dislike of religion, which he must have felt was stifling the French of Quebec.

\section{Le Cercle Français}

The McGill Calendars have outlined Messac's teaching; the Progrès civique articles have revealed his reactions to America. Another source, the students' McGill Daily with its reports of meetings of the student club Le Cercle Français gives an idea of Messac's personality and dry humour - a nonfictional source to compare with Smith Conundrum's autobiographical portrait. Messac's informal contact with students in the Cercle contrasted with his protagonist's frustrations in the novel. The Cercle may have seen Messac's happiest moments on campus. The Cercle was open to all male students; the French Department staff served as animators (Fig. 5). Women students had the equivalent Société Française. The two groups met once each term for dancing and debates. The Cercle, founded in 1905, boasted that McGill, in the center of French Canada with a strong French department, was an ideal place to practice French. ${ }^{57}$ The Cercle held debates, some typical of college humour ("Are men the weaker sex?"58), others on serious economic and social issues. The Daily reported the Cercle's debates in more detail than it gave to the other 75 student societies, except athletics. Messac and his young colleague André Jean Roche sometimes teamed up to lead meetings. ${ }^{59}$ [Messac borrowed Roche's first name and middle initial, for his satire's protagonist André J. Pluche.] At Messac's first Cercle meeting on 15 October 1924, du Roure pointed out that McGill had high standards for teaching French and was the only English-speaking university where only French was spoken in classes. Messac was introduced "and he proved himself very entertaining with his first talk before this organization." He also suggested the first topic for debate: "Resolved that dancing is immoral," which he had heard debated during his year at Glasgow..$^{60}$ [Messac probably did not know Leacock had written about this chestnut in $1921 .^{61}$ ] The debate veered from the evils of jazz to the beauty of Pavlova's dancing. Messac and others gave (unrecorded) opinions and Messac, who was one of the judges, announced that they "felt constrained to present the palm to the affirmative, which had won on debating points." ${ }^{\prime 2}$ The debate even reached the editorial page of the Literary Supplement of the McGill Daily, edited by A.J.M. Smith, which advised that in view of the result Cercle members must not dance. The
Supplement, soon followed by the McGill Fortnightly Review (1925-1927), championed modernist poetry and leftish views. Messac may have had them in mind when he mocked the review Spirochetus in Smith Conundrum-although these publications shared many of his views, in particular, that athletes should be held to the same academic standard as other students. ${ }^{63}$

In other debates in late 1924 the Cercle carried the motion that "Professors are Indispensable at the University." Should railroads be privately or publically owned? An important question in Canada, with its huge spaces held together by rail; privatization won. Leacock, who usually attended one meeting a year, because of his interest in French and friendship with du Roure, suggested the topic "Is the pen mightier than the sword?" It was announced that "Dr. Leacock and Free Cigarettes" would draw crowds and that du Roure, Villard, Messac and Roche would lead the discussion afterwards. The Cercle decided the pen was stronger than the sword. One debater had remarked that Bulwer-Lytton, cited as the originator of the proverb that the pen is mightier, was a mediocre writer. ${ }^{64}$ Perhaps this inspired Messac to publish an article on Bulwer-Lytton in 1926, although Bulwer-Lytton also figured in his Detective Novel thesis. Leacock could not attend the meeting but later observed that debating topics like railway ownership had the good effect of forcing students to go to the library and read books. ${ }^{65}$ In February 1925 the Cercle decided "that we should prepare for war in order to prevent it." Messac and Roche addressed the meeting after the debate and their speeches were appreciated; one wonders whether Messac supported pacifism. ${ }^{66}$ Both men had served in the first war; both would be home in France during the second. At the Cercle's first Fall term meeting, in October 1925, "Messrs. Messac and Roche contributed a few entertaining words to the meeting and by that time the formality of the gathering had vanished...." ${ }^{n 7}$ The next meeting featured a lecture by $M$. Robert on the history of Canadian elections; afterwards, du Roure called on Messac and Roche to speak, "both of them contributing much to the merriment of the evening. The one with anecdote [sic] concerning Parisian elections, and the other with the relation of an incident on shipboard." 68

The fullest record of Messac speaking at McGill came out of the Cercle's debate on whether moving pictures were beneficial. Films brought up the issue of censorship, American influences and evil effects on the young. The Cercle's debate on 23 November 1925 probably helped spark Messac's chapter Film interdit par le censure in Smith Conundrum discussed later. It was announced that the program would include a talk by Messac: "Prof. Messac is well-known at the Cercle, and since his arrival at McGill has been a very hearty supporter. His address is sure to be one of interest, and will probably include some of his clever wit and humour." ${ }^{\prime \prime 9}$ The debate was won by those arguing moving pictures were harmful and that students should not attend them. A pendant to the debate, Messac's speech was "a very interesting and humourous talk on 'stage 


\section{WEATHER FORECAST GROWING COLDER}

Vol. XV., No. 47.

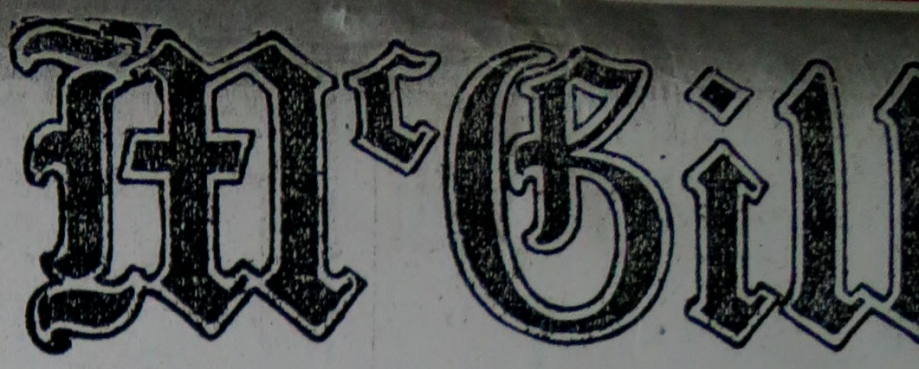

MONTRE

UNDERGRADUATES NOT TO ATTEND MOTION PICTURES

\section{Decision of Cercle rrancais in Debate}

\section{PROF. MESSAC}

Advice to Embryo Public Speakers on Stage Fright

Moving pictures are not beneficial to the public and are therefore not to be frequented. This was the decision rached by the Cercle Francaise ai a debate on the subject of motion pictures, last night. The affirmative was couragcously defended by pemberton and Urquhart, while Jacques Herdt and Ray Caron carrled the negative on to victory. The question, however, was closely contested and winners had a very small majority.

Hrof. Messac, of the French department was the guest of honour and Gave a very interesting and humourous talk on "stage fright." He discussed the matter in connection with actors ard public speakers, and concluded by giving some useful advice to novices in the art of public speaking.

The term "stage fright" was used express those emotions that seize inexperienced pub!.c speaker when adessing a critical audience. This finition, however, cannot be taken word for word, because, even experienced speakers have often been taken w.th this emotion of "le trac" This condition might be a cause of amusement for the audience but it means
DR. PERRIN WILL DELIVER LECTURE

The subject of the second of the series of "Lectures on Appreciation of Muslc" given by Dr. Perr!n, the Dean of the Faculty, is 'Italy and the Music of Corelli' Thilig Lecture which will be given on Wednesday evening, November 25 th at 8.30 p.m. in the Hall of the Conservatortum. ought to prove particularly interesting as it will be illustrated by lantern slides, as well as by the music of that composer. The lecturer will be assisted by Miss Kathleen Perrin and Miss Beatrice Earle (Violinists) and by $\mathrm{Mr}$. A. Goldberg (Violonceilist).

The course of ten lectures is open to the public at a fee of $\$ 5.00$ but the Fxtension Department wishes it to be known that anyone desiring to attend a single lecture may do so on payment of Fifty Cents.

\section{BLISS CARMAN GAVE ADDRESS ON FWE ARTS}

Showed Iheir Probable Development

\section{PRACTICAL USE}

Interpreted Selections from Browning and His Own

\section{Poetry}

"Poetry should express man's rela. tion to the unseen and the other rorld to God and the material of

\section{WINTER SPORTS ORGANIE SOON}

Uuting Club Holds General Meeting Friday

The first general meeting of the MoGill Winter Outing Club for the 1925-26 season will take place in the McGili Union next Friday afternoon at $f$ ve o'clock. when plans will be discussed. and the organization for the year completed.

The season promises to be a busy one, and arrangements will be made on Friday concern ng the entry of several McGill men in the Quebec W nter sports carnival. This will be held upon Dec. 30 , and a team from McGill will in all probabil ty compete. The famous carnival at Lake Plaod, on Dec. 30 , and 31 , will also see a group of Red-and-White competitors, f present plans go through.

The Canadian Intercolleg ate Divisional Winter Sports Meet will be held $n$ Montreal on February 12 and 13, and the final interoollegiate meet about a week later in Hanover, the home of Dartmouth. These latter dates are rather uncertain, but the contests $w$ il be held about that time of the year.

If sufficient support is forthcoming, it is probable that the Club will organize trips to the Laurentians over the weekends during the winter. These would be held at comparatively little cast, and would provide the average nember wh much unusual experience.

The executive of the club is very anxious that as many men as possible attend the meeting on Frday, and first year men are especially invited to attend. Every skier, snowshower, and skater $n$ MeGill is expected to 
fright.' He discussed the matter in connection with actors and public speakers, and concluded by giving some useful advice to novices in the art of public speaking." Messac's speech in French was summarized in English by the Daily (Fig. 6):

The term "stage fright" was used to express those emotions that seize an inexperienced public speaker when addressing a critical audience. This definition, however, cannot be taken word for word, because even experienced speakers have often been taken with this emotion of "le trac." This condition might be a cause of amusement for the audience but it means much embarrassment and suffering for the unfortunate speaker. To overcome it, a very practical suggestion was to speak plainly and simply, not trying to resort to words and language of any sophisticated nature. Prof. Messac remarked that this state of affairs is often present in students, especially at exam time. It was also pointed out that professors are in a position to derive much pleasure from such afflicted students, but McGill ought to feel very thankful that all the professors are of a much kinder nature.

An analysis of this emotion of "stage fright" shows it to come from a feeling of timidity which is in turn due to an attitude of inferiority. Now if this primary cause is eliminated the whole thing is done away with. Thus some more practical advice was to take on an attitude of superiority and leave no room for timidness and hesitation. ${ }^{70}$

One of the Cercle's avowed benefits was that students met their professors on an equal footing and as guest of honour Messac remarked on the 'en famille' atmosphere of the meeting. The winning debaters admitted that they actually liked movies. The Daily's editorialist, probably Leon Edel, used the debate result, headlined as "Undergraduates Not To Attend Motion Picture," to make fun of the Cercle's pomposity and presumptuousness just as the Literary Supplement had of the no-dancing decision. The editorial decried the poor quality of motion pictures: their "crude sentimentality, the abominable ignorance, the downright nonsense of most of the pictures produced to-day are facts to be greatly lamented." But if students participate in other low forms of culture such as dancing the Charleston then why single out motion pictures? $?^{71}$

The Daily next mentioned Messac in November 1926, when the Cercle debated professionalism and sports, a subject which Messac would develop in Le Progrès civique in August 1928, discussed above. The meeting voted that professionalism harmed sports. Discussion was lively: "Some very original opinions were expressed upon the subject, particularly by Professors Messac and McCulloch, who joined heartily in the argument."72 Paul McCullagh had just arrived as a Lecturer in Classics and attended the Cercle - he would stay at McGill for 60 years and possibly may have been a model for Addison in the chapter Honoris Causa in Smith Conundrum..$^{73}$ The related issue of sports at universities was debated hotly at McGill and elsewhere. In March 1927 the McGill Fortnightly Review, the voice of the literary students, argued that "one realizes the dangers of athleticism when Mr. Shaughnessy pats the professors on the back for not plucking a student because he turns out for the football team, and for being willing to give the football squad extra lessons to make up for lectures that have been lost through practices." ${ }^{74}$ In North America, university sports, notably football, conferred prestige and raised money from alumni. Frank Shaughnessy, McGill's famed football coach, was better known than any professor except Leacock. Some student critics declared there was too much emphasis on sports, that college sports were being carried on commercially to the detriment of learning, and decried the influence of the athletic director Major Forbes. ${ }^{75}$ Agreeing with this, Messac satirized Forbes ("Colonel Martlet" in his novel) and sports boosterism at McGill generally in his chapter Le Rah Rab Boy. The Daily last reported Messac in late February 1928. Du Roure had spoken on economic conditions in France and mentioned that French student organizations did not work well. "Discussing the reasons for this, it was suggested by Professor Messac that it was due to the tendency of the Frenchmen to be individualistic." ${ }^{76}$ Although Messac was elected the Cercle's honorary vicepresident for 1928-1929, he is not mentioned as present at meetings. It seems likely that his enthusiasm displayed from 1924 to 1927 had declined as he concentrated on finishing his thesis and, perhaps, became more disenchanted with McGill. And Germaine was pregnant.

\section{SMITH CONUNDRUM}

\section{Introduction}

The college fiction genre became increasingly popular in America in the 1920s as enrolments increased and this golden stage of young peoples' lives seized the imaginations of writers like Scott Fitzgerald. Messac's caustic novel from a professor's viewpoint contrasts with two other evocative visions of McGill in fiction: Dink Carroll's unpublished novel about a football-playing fraternity student of the same era (1920s) and Norman Levine's nostalgic siftings of his student experiences of the late 1940s. ${ }^{77}$ Even more than Carroll and Levine, Messac drew on the specific character of McGill at a certain time: its staff, events and architecture; unlike them and most others writing about McGill, he made little play of the alluring Montreal setting. [McGill must be the most frequently mentioned Canadian university in fiction. I have found at least 800 novels and stories with passages on McGill, dating from 1870 to the present. In at least 50, student or faculty life plays a major role.]

Smith Conundrum is the fictional side of Messac's "American" journalism which we have seen in Le Progrès civique: the 
novel continues the same themes-snobbery, stupidity, hierarchical rigidity, and fascination with measurement and technology not real knowledge. The novel began appearing as long vignettes in Le Progrès civique in 1928 while he was still at McGill, under their own chapter titles and in their final form, but not yet ostensibly as a novel titled Smith Conundrum. ${ }^{78}$ He probably considered the chapters as part and parcel of his other writing on America for Le Progrès civique-but more fun!-and may not have planned a full novel until more chapters had accumulated by 1931. Although announced in 1935, with the complete title Smith Conundrum: roman d'une université américaine, the book only came out in 1942, in German-occupied France. Most copies were destroyed in the war, by the Germans on purpose and the American army by accident. ${ }^{79}$ Marc Angenot of McGill's French Department discovered the novel in 1975 and identified the "American" university as McGill..$^{80}$ The novel was republished in 2010. As Angenot notes in the 2010 preface, French readers would not have been interested in Canada or Quebec but were very interested in America. Likewise, having to recreate the real life setting of Quebec with its language and national issues would have distracted from the self-contained world of the university which Messac wished to portray. ${ }^{81}$ Accordingly, Messac located Smith Conundrum in the American state "West Washingtonia" in an unnamed city. The novel was subtitled roman d'une université américaine both when it was announced on the forthcoming list of la Fenêtre ouverte in 1935 and finally published in 1942 and reprinted in 2010 (Fig. 7). Internally, the text reads as set in the United States. However, when the chapter l'Académicien was published serially in 1931, the brief editorial introductory note [not by Messac, presumably] revealed that the action of that chapter takes place "dans une université canadienne." ${ }^{22}$

The novel challenges us to detect the events and people that inspired Régis Messac. What is real, what is invented? Only by knowing the context, can we see how closely Messac turned his daily routine into striking satire. Unlike Leacock's college satire, which seldom had real life back stories, Messac's rather convoluted and involved plot, especially the later chapters, can only be appreciated fully if one knows what personalities and situations he and his protagonist were

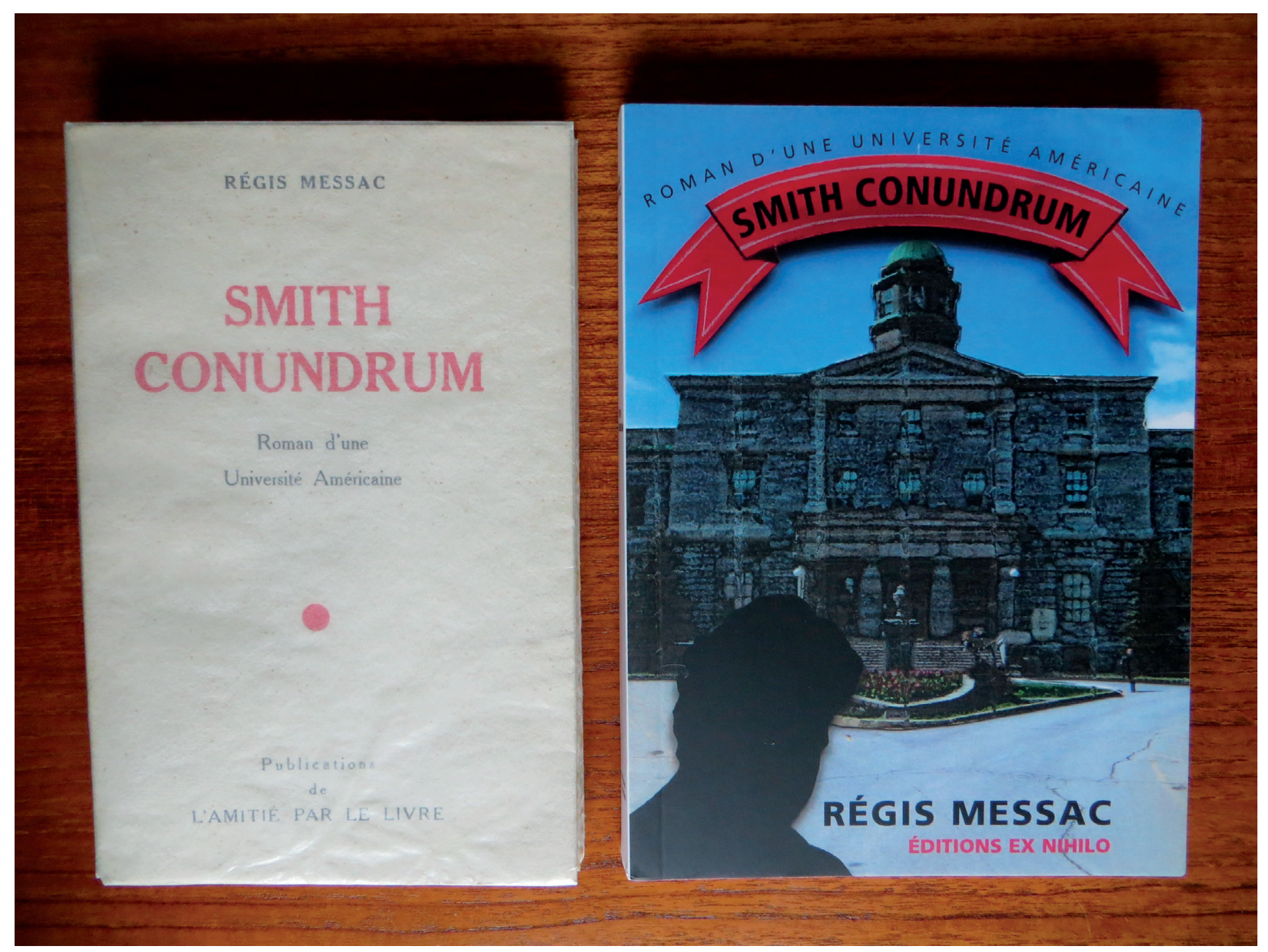

Figure 7. Smith Conundrum: covers, 1st edition 1942 (L), 2nd edition 2010 (R) 
reacting against. Messac, who loved leaving clues, might have enjoyed the present article's exercise in detection. The novel's 35,000 word text is in French, told in past tenses. Each chapter is a vignette of academic life with seasonal changes but not strictly following the academic year. Some of the chapters represent the timeless absurdity of academic life, others were inspired by specific events during the five years that Messac taught at McGill (Pluche was at Smith Conundrum for four years not Messac's five). It is a unique take on McGill from the viewpoint of a discontented assistant professor. We know the thoughts of Messac's alter ego André Pluche; his scholarly and anti-hierachical attitudes resemble Messac's in Le Progres civique but are milder, more naïve. Pluche slowly learns he cannot instill scholarly knowledge where incompetence and indifference to learning rule. While Messac gives no dates, he refers to Prohibition, bootlegging, Lindbergh (1927) and the Kellogg Pact to outlaw war, signed 27 August $1928 .^{83}$ Messac wrote most of the novel from 1928 to 1931 while McGill was fresh in his mind. The novel still awaits English translation. ${ }^{84}$

Messac's protagonist is a newly hired professor of French, AndréJ. Pluche. The name Pluche probably reflected Messac's admiration (as a scholar of popular literature) for the science popularizer Abbé Pluche (1688-1761). ${ }^{85}$ A quietly ironical slightly naïve version of Messac, Pluche closely resembles his creator; he is short, dark with anti-establishment views. ${ }^{86}$ Pluche talks to himself; did Messac? Pluche unlike Messac is single-this lets the plot focus wholly on his university life. Pluche and Messac are both preoccupied by research for their PhDs. Pluche lives on the fourteenth floor of the "California Building." Messac loved dropping twisty literary allusions: Sinclair Lewis's Babbit (1922) was glad that his own office building, also fourteen stories high, was three stories higher than the "California Building" in downtown Zenith, U.S.A. ${ }^{87}$ Pluche's high rise residence also may have been inspired by the ten story Maxwelton apartment building facing the McGill campus. The campus with its "Gothicocorinthienne" architecture matches McGill for the most part, down to what Pluche/Messac saw as the fake gothic of Presbyterian College (Morrice Hall) and the new-world attempt at cathedral stained glass windows in Redpath Library. Many characters, circumstances and events can be traced to real ones. Like McGill, Smith Conundrum is named for its wealthy founder; like James McGill (1744-1813), Smith Conundrum is buried on campus under a stone urn (Fig. 8), and like the Scot McGill, who made a fortune on the fur trade, the Welsh-born Conundrum also had made his money on animals - but on their entrails not their fur. Pluche enters Smith Conundrum's campus through recently built monumental stone gates which cost \$50,000; the new Greek columns of the Roddick Gates, built during Messac's first year at McGill, cost exactly the same. ${ }^{88}$ Yet Pluche has just been refused a paltry $\$ 45$ dollar annual raise. Messac would have received the then standard McGill salary for assistant professors of (CDN) $\$ 2,500$ : liveable but not the $\$ 4,000$ to
$\$ 5,500$ of higher professors. In 1926 when a $15 \%$ pay rise was in sight, Ira MacKay, Dean of Arts, suggested to Principal Currie that it would be better to increase the salaries of the principal men in departments rather than fritter funds away "on minor men teaching minor courses." ${ }^{\text {"In 1927-1928 }}$ McGill had 83 full professors, 34 associate professors, 68 assistant professors and 93 lecturers. ${ }^{90}$ There was a strong division between full and associate professors and the more lowly assistants and lecturers. Pluche like Messac felt trapped by low status and low pay.

\section{Messac, Leacock and McGill Satire}

Pluche carries a book titled English style explained through Army secret Codes "by a Chicago professor." This and Pluche's Ph.D. thesis under way for University of Chicago are Messac's sly homage to Leacock who wrote his Ph.D. at University of Chicago (under that scourge of business influence in America, Thorstein Veblen). Messac even cited Leacock's Nonsense Novels in his thesis as parodies of the detective genre. ${ }^{91}$ Leacock was McGill's best known teacher and a great friend of du Roure. While there is no written evidence, ${ }^{92}$ Messac would have known Leacock and must have been influenced to some extent by his satirical writing on McGill and universities in general. Messac and du Roure had their students translate Leacock's nonfictional bestseller

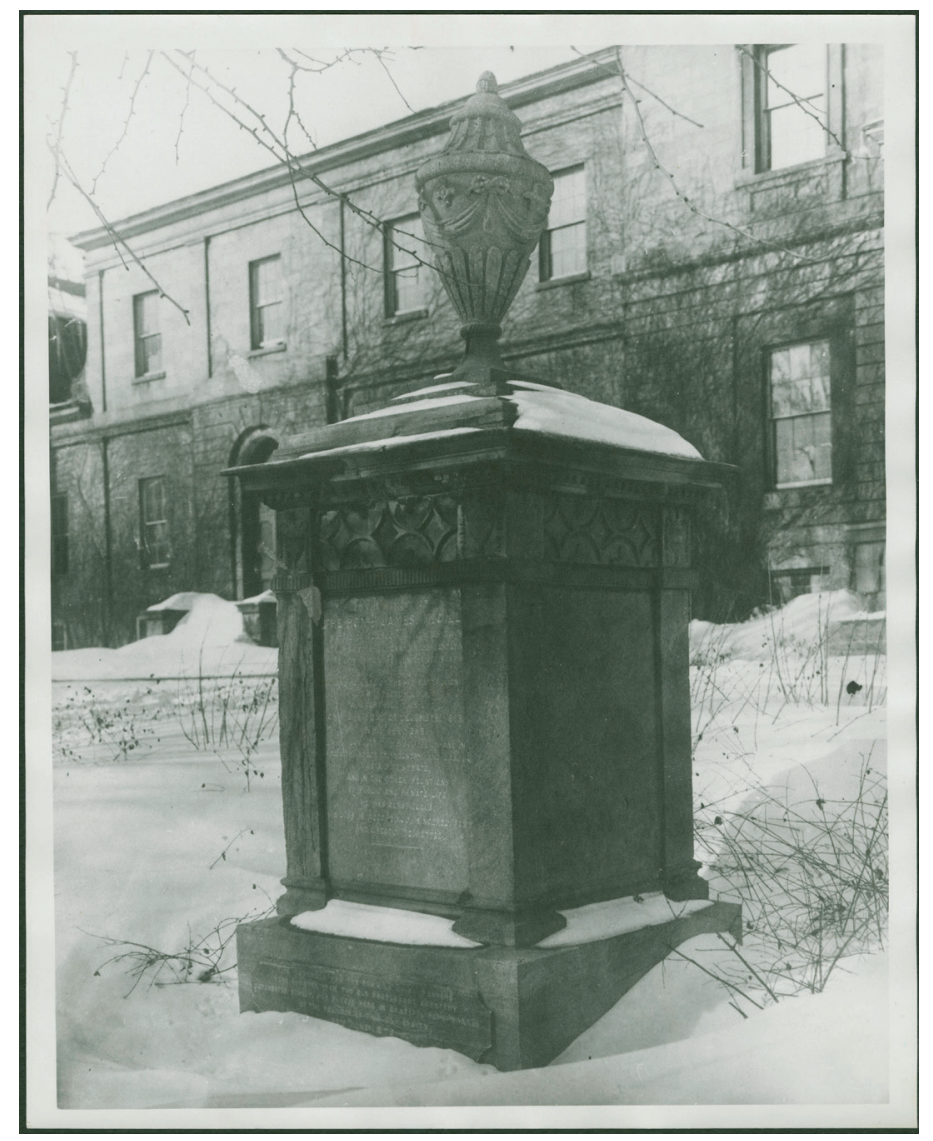

Figure 8. James McGill's tomb, Arts Building, ca. 1925, photographer unknown, MUA PR012450 
My Discovery of England (1922) as exercises for their courses so Messac would have known that book's satirical comments on American university education and agreed with them. Both Leacock's and Messac's satire partly originated from their social criticism and contempt for religious enthusiasm, Bible colleges, teetotalism, puritanism, pseudo-scientific intelligence testing, and from their distrust of unrestrained capitalism and money's power to influence universities. Like other critics, they loathed the American elevation of business efficiency and social skills to academic status. Leacock satirically had advised Oxford to copy North American universities, have courses in salesmanship, and seek wealthy donors. He cited Chicago's oil money [Rockefeller's] and McGill's tobacco money [Macdonald's]; Oxford should also imitate the American practice of selling honorary degrees to millionaires. Messac excoriated all these practices, not in his novel but in his article "Bunk."93

By the 1920s, as Messac could not have helped realizing, Leacock had established himself as the standard of satire (both fiction and nonfiction) on universities in general and McGill in particular. Messac's satire is more biting and pessimistic than Leacock's gentler tone and has a dose of malice towards lazy students and incompetent teachers not found in Leacock. Perhaps this reflects their different positions as icon and junior professor. Yet although edgier, more detailed, Smith Conundrum falls into the tradition of Leacock's satirical college fiction. Leacock's best known one was a section of Arcadian Adventures Among the Idle Rich (1914), set at Plutoria University, recognizably McGill but located vaguely in the United States - for better sales, just as Smith Conundrum would be for greater attraction to readers in France. Unlike Arcadian Adventures, however, Messac's entire novel is about university life and and has more sustained focus than Leacock's on the protagonist's character, which develops (mainly through disillusionment) as the novel progresses. Though both depended on loosely connected episodes, Messac wrote a novel, Leacock stories. Messac did not name McGill while Leacock often did, in his essays, poems, and skits. Leacock wrote many works making fun of college life; Messac just one. Leacock's situations are often more absurdly fanciful than Messac's - in his long story (1932) "Rah! Rah! College," Tom Buncom, at the American Shucksford College which has given up lectures to allow students more club time, majors in dog-walking. ${ }^{94}$ Messac's satire was more obscure, private, and drawn from real circumstances; it is less easily and universally accessible, less fun-loving and whimsical, than Leacock's. Messac kept to the real and plausible. While Leacock based characters in Sunshine Sketches of a Little Town (1912) on real people and President Boomer in Arcadian Adventures resembled McGill Principal William Peterson, most of his characters, if they existed, bore few descriptive clues and are untraceable. Much more than Leacock, Messac derived many of his characters and episodes from traceable McGill originals and in sharper, more unflattering detail.
He usually started with real people, even if the point of resemblance was merely something such as old age (like Dean Bunk/ Ruttan, called senile in Honoris Causa, below) and not developed further. Yet a few of Messac's characters, Professor Talkinghorse for example, seem as purely invented as any of Leacock's. Both satirists invented funny names: Messac's Deans Heluva, Cattle and Bunk vie with Leacock's Dean Dump and Rev. Mumble in "Rah! Rah! College." Both Messac and Leacock satirized female students in particular; both mocked dim students, business influences, and the teaching in academe of subjects like salesmanship or hygiene. ${ }^{95}$ While their satire (and indeed most college satire) was similar, their personalities, politics and circumstances differed greatly. Twenty-four years older, Leacock was the reigning "character" on campus, an imperialist and conservative (with a streak of "red Tory" ${ }^{\text {"96 }) . ~ M e s s a c ~ w a s ~ l o w ~ o n ~ t h e ~ t o t e m ~ p o l e, ~ l e f t i s t, ~ a n t i-~}$ war, anti-hierarchy, and anti-religion. Leacock was happy at the "American University," Messac probably was not.

\section{La fille de Peudzippah}

Following Pluche through the chapters of Smith Conundrum, we progress from the early light ones to later gloomier, didactic ones. Pluche starts naïve, finishes cynical. Occasionally Messac's phrases will be loosely translated and integrated here to convey his style. ${ }^{97}$ Pluche enters the main building, based on the McGill Arts Building [where Messac's office and classrooms were], refurbished in 1925-1926 with shining marble and double ranks of stairs. He tries to teach his class the beauties of Racine's Phèdre. Miss Bloomfield valiantly mispronounces the name of Phaedra's mother, Pasiphae, as "Peudzippah." [Messac ridicules the students' French-and English - accents mercilessly.] Horrified to discover the class knows no classic myths or ancient history, Pluche blames the chairman of the History Department, Alexander Snuffbox, Ph.D., whose thesis of only 59 pages was on "George Washington's Tactics at Great Meadows." Snuffbox matches History chairman William T. Waugh, an expert on James Wolfe, conqueror of Quebec..$^{98}$ Not surprisingly, Messac Americanized Waugh's Wolfe into Snuffbox's Washington. Besides the satirist's usual exaggerations, Messac may have mistrusted Waugh for his friendship with Principal Currie and for his grandiose 41 day tour of Canada lecturing on Wolfe in 1926. Pluche asks if the class knows what Greece is. Miss Calvinson replies, it is a little country in Europe... there are ruins. Pluche gives them a quick history of Greece, the Trojan War, but to no avail. Harry Swellhead, a football player sneers. When Anita Loveduck starts doing her lipstick, Pluche knows his lecture hour is up. Swellhead and Loveduck represent hormonal indifference to learning. Outside after class, Pluche is nearly run down by a huge car driven by Swellhead, with his arm around Loveduck, and imagines his death written up in the Smith Conundrum Daily. Messac captures the freedom which McGill and American students enjoyed. University culture in Canada and the 
United States was similar. The McGill Daily discussed kissing and "petting." Students owned cars, courted, joined one of the twenty fraternities and dozens of clubs, dined in the cafeteria of the student union, and cheered at football and hockey matches. The Smith Conundrum girls wear furs and "kiss-proof" lipstick (favoured by both sexy Anita Loveduck and cerebral Goldye Belemnith). Were the students as dim as Messac portrayed them? Some McGill students, like Frank Scott and Maysie MacSporran were brilliant, some were not. Apropos, the McGill Annual Report of 1924-25 complained that many students could hardly write, quoting hilarious illiteracies - which may have inspired Messac. ${ }^{99}$

At the end of the chapter, when Pluche plans to flunk Swellhead, "Père Dubois," a father-figure and older professor of French, explains the facts of life to Pluche (there is a camaraderie among the few Frenchmen at this "American" university). Dubois warns Pluche that Swellhead as an athlete is too important to be sacked and besides his father is a Senator. [As already noted, at McGill it was often complained that professors were unwilling to fail athletes, since that would disqualify them from competition. Messac agreed with this complaint; indeed, he published this chapter in Le Progrès civique in September 1928, only a month after his attack in the same journal on America's sports professionalism. As usual he made the same points in his novel as in his journalism.] Père Dubois appears in nearly every chapter, far more frequently than anyone else but Pluche himself. He is friendly, unflappable, a foil for Pluche, whom he advises to conform to the low standards and social obsequiousness of the University. Superficially, he matches the popular Associate Professor Paul Villard (1867-1952), a Frenchman who had graduated from University of Paris in 1887, had ties with French organizations in Montreal (he was Secretary of the Alliance Française), was a Protestant minister (hence "Père"?) and held a medical degree from Bishop's University. ${ }^{100}$ Dubois and Villard are both viellards with white hair. Villard had charge of French courses for Commerce students; they called him Papa Villard (hence "Père" again). Villard was the highest in rank after du Roure-he had been promoted to Associate just before Messac arrived in 1924. At this point, it should be emphasized that the novel was a satire. Like most satirists, Messac used details from real people to create fictional characters. Personality flaws and quirks were inflated or created for effect; the characters took on their own lives. While Villard, du Roure, Principal Currie and others initially inspired Messac's characters and resembled them in appearance and other circumstances, one cannot know if they ever acted and spoke as their fictional shadows are portrayed. Presumably Messac took the usual authorial liberties of simplifying, exaggerating and inventing. Though not considered a specialist, Villard was judged " a very useful all-around man." ${ }^{101}$ Villard, du Roure and Currie played important roles-but they could not claim to be innovative scholars and their positions above Messac made them fair game for parody - as Père Dubois, des Boys de la Tour and Rumblebass Balderdash respectively .

The description sof students, staff and architecture all match McGill's. While the initial inspirations for Pluche's fellow professors can be traced to real people (see Appendix), the students are archtypes (dim, talkative, rich, athletic). If they were based on real students there is no way to identify them. Pluche's students are from the mixture of races Messac found at McGill: English, Scottish, Irish, French, Jewish, German, East European and Italian-blue eyed Gretchens, athletic Scandanavians, and even a Japanese. ${ }^{102}$ Rivaling Shakespeare and Dickens, Messac invented names and characters were born! Calvinson, Pilgrim, Bloomfield, McRaevity evoke Smith Conundrum's (and McGill's) ethnic variety. Other names conferred personalities: Harry Swellhead, Pixie Pickering and Rumblebass Balderdash, while Prosper Doughnut, Anita Loveduck, and Lord Pyff are delightfully fanciful and Colonel Martlet suggests martinet. ${ }^{103}$ Messac had a sharp ear for both slang and formal English. His letters in English between 1928 and 1939 to Thomas Mabbott, C.K. Ogden and David Keller (he translated the latter's science fiction into French) were clear and grammatically correct. ${ }^{104}$ Some of the novel's names probably were adapted from the names of real people-perhaps both Pluche's department chairman des Boys de la Tour and Père Dubois from a student, R.M. DuBoyce (B.A. 1928, B.CL. 1933), whose paper Messac took back to France. ${ }^{105} \mathrm{Du}$ Roure's aristocratic family was des Royes (or Roys) du Roure ${ }^{106}$ so the fictive chairman's full name "le vicomte des Boys de la Tour" (hereafter des Boys) plays on that as well. Messac gave English characters amusing names, such as Joshua Heluva for a Dean of Theology, while French characters often had inflated, aristocratic names.

\section{Le Professeur Talkinghorse et l'idée de genie}

Pluche goes to the Library, walking quickly so he will look efficient and American. He reviles its stained glass [Victorian gothic Redpath Hall] as worse than Lourdes or the Woolworth Building, and sees students comatose after drinking "hooch whisky" all night. In the library he sees Cadwallader H. Talkinghorse, M.A. Ph.D., Parsley Professor of Ethics and Moral philosophy who has long legs, wide shoulders and an equine profile. Talkinghorse is measuring the lengths of articles in the Encyclopedia Britannica in order to discover the relative importance of historical figures. $\mathrm{He}$ has made a list of measurement results: Galileo scores impressively at $1.35 \mathrm{~m}$ while Napoleon scores $2.50 \mathrm{~m}$; Nelson $3.25 \mathrm{~m}$ and Dante $1.23 \mathrm{~m}$. Pluche shatters his colleague's method by pointing out that he must take the language of his encyclopedias into consideration: English and Italian encyclopedias will differ as to the relative lengths they give Nelson and Dante. Talkinghorse checks. The Italian encyclopedia gives Dante $4.75 \mathrm{~m}$ and Nelson only $0.33 \mathrm{~m}$. Poor Talkinghorse drops his research; Moral Philosophy will 
not make the advance he hoped for. Talkinghorse's ponderous name, endowed professorship and earnest simple mindedness typify Messac's idea of the American academic. In name and title, Cadwallader Talkinghorse, Parsley Professor of Ethics and Moral Philosophy resembles Dr. William Caldwell, Macdonald Professor of Moral Philosophy, 1904-1929, campus eminence, personality and speaker on foreign affairs who, with Leacock and others, helped introduce Chicago School sociology and social work studies at McGill. However, Talkinghorse's nonsensical research seems purely invented, to symbolize the American obsession with measuring and testing or even to swipe against data-collecting research methods of Chicago, where Caldwell had taught briefly. ${ }^{107}$

\section{Graeculus Esuriens I, II}

This two-part chapter develops the theme of dim students and Dubois' advice that they must not be failed, especially if they are from important families. Snow falls as Pluche corrects examinations in his overheated attic office. The French Department rooms are cramped to give Talkinghorse a large suite to arrange his research files. Enter Dubois. Pluche groans that he has 341 exams to correct. He must read the same dull answers about the history of France and Maupassant's necklace story 341 times! He reads Dubois the answers written by Goldye Belemnith; she has mixed up her fictional with her historical readings. Sad isn't it? Pluche asks. Terrible, replies Dubois. What do you think it is worth? asks Pluche. Indulgence is our rule here, says Dubois. You can't mark these girls like French ones. Pluche suggests a mark of 48 out of 100. Dubois fidgets. Do you realize Goldye is the niece of Bishop Exeter Belemnith, the brother-in-law of our Dean? Then should I give her 75 ? asks Pluche. At Columbia University, says Dubois, they seldom give less than 95 . [Columbia was a centre of French studies; Baldensperger's colleague Paul Hazard gave a far happier report of its students in the 1920s. ${ }^{108}$ ] Understood, says Pluche; Smith Conundrum must not be left behind. Pluche muses on his own very different education at the Sorbonne: I learned Latin. He tries to recall a line he learned from Juvenal. You're not at the Sorbonne, declares Dubois; you cannot treat Goldye like a sorbonnarde. I'll give her a 98, says Pluche. Now you're being reasonable! says Dubois. Pluche recalls the line from Juvenal: Graeculus esuriens ad caelum jusseris ibit! Pluche is probably comparing his own circumstances to the hungry Greek scholars who performed all kinds of servile services to survive in the Roman Empire - the Smith Conundrum professors are Greek slaves, the students their Roman masters. ${ }^{109}$ [In 1933 Messac would scandalize traditionalists with his book A Bas le Latin! ${ }^{110}$ Whether he was ever pressured at McGill to mark gently is unknown.]

Two days later, a girl comes into Pluche's office. Muskrats have been sacrificed to cover her from head to foot: she is as pretty, bold and banal as a cigarette advertisement. She is
Goldye Belemnith to whom Pluche gave a 98 after prodding by Dubois. Her French stumbles. "Prof'sieur Diouboisse ma dit... told me how nice you were." Pluche offers to speak English. ${ }^{111}$ She replies she can speak French and that she is a "pouate," She even writes verse in French. Better and better, says Pluche. Goldeye tells Pluche she has founded a bilingual literary journal, The Spirochetus (Bacteria!). Messac was mocking the McGill Daily Literary Supplement and its successor the McGill Fortnightly Review, run by iconoclastic student writers A.J.M. Smith and Frank Scott; Messac's invented Spirochetus probably alluded to the Literary Supplement's controversial publication of an Aldous Huxley verse on "spermatozoa." ${ }^{112}$ Ironically, if he had not been writing satire, Messac would have approved of these journals, which aired socialist and anti-war views, and criticized the orderly, conservative, hearty, sports loving university of Sir Arthur Currie. ${ }^{113}$ Thanks to Pluche's first class grade, Goldye will do a master's degree. Since she is interested in both Mallarmé and Freud, she proposes a thesis on Mallarmé, explained by Freud. Splendid, gasps Pluche. ${ }^{114}$ As she leaves, refreshing her kissproof lipstick, Goldye says Pluche does not deserve his reputation d'ours (perhaps a play on the plush [peluche] of which toy bears were made). Maybe Messac thought his students found him grumpy and demanding.

\section{Film interdit par la Censure}

Dubois invites Pluche to a private screening of a film based on Corneille's Le Cid, before any cuts are made by the censors. Does the film have naked women? asks Pluche. Dubois replies that the film is more likely to be censured for political reasons. Dignitaries will attend, including le Marquis du Quartier de Montrouge of the French consulate who also (strangely) happens to be on the local board of film censors [the real life Consul was Baron Régis de Vitrolles-another aristocratic title for Messac to improve on]. Pluche and Dubois meet at the Princess Theatre [which really existed; Houdini performed there on 22 October 1926, was afterwards test-punched by a student apparently registered at McGill, and subsequently died. ${ }^{115}$ ] The fictional audience includes representatives of the Association for the Protection of Women and the Home as well as consular officials from Spain and France.

The film is Messac's rewrite of Le Cid as a Hollywood western set in Texas, full of complicated pranks, violence and murder. Messac casts Charlie Chaplin as the hero El Cid Campeador, renaming him "Syd Camp-eater." After the film is shown, Joanna Marplot, Miss McThormy and Reverend Minus Habbins, boiling with Anglo-Saxon outrage at indecency, demand the film be censured because its plot and Chaplin are both immoral. For their part the French and Spanish consular officials storm against the film's insults to their national honours. All agree the film must not be shown. The manager of the Princess accepts this philosophically. He 
will screen a Cowboys and Indians western instead. The farce is complete.

Messac liked the subject of films; in parts of the novel Pluche watches events unfold as if in a film or drama. Messac had fun pastiching a classic and attacking censorship, puritanism and nationalism at the same time. ${ }^{116}$ Overlapping as he often did with his Progrès civique articles, Messac also used "minus habbins" to personify the illiterates who easily gain titles and prestige from American institutions. ${ }^{117}$ The chapter's women are modeled on the English Montreal reformers of the 1920s who tried to abolish vice in the "Paris of North America." Messac also may have been inspired by the Cercle's debate on films, already discussed, or by the presentation of Corneille's Le Cid at McGill in November $1928 .{ }^{118}$ Moreover, in the mid-1920s it was well known at McGill that Stephen Leacock was being courted by Charlie Chaplin as well as by Douglas Fairbanks and Mary Pickford to write screen plays for them. ${ }^{119}$ Finally, Messac taught Le Cid in his courses. With these McGill stimuli, this chapter on Le Cid and Chaplin seems inevitable!

\section{Jamais Content}

The elegant, unflappable head of the French Department, vicomte des Boys de la Tour is modeled on the aristocratic René du Roure, Chairman of the McGill Romance Languages Department, 1923-1940. ${ }^{120}$ Pluche gives his own courses between 9 and 11 in the morning. This leaves him the rest of the day to work on his Ph.D. thesis-whether Messac's schedule gave him the same free time is unknown. Consequently, Pluche seldom sees des Boys who, like his real life model du Roure, never arrived on campus before 11 a.m. Now they are to meet in in Room 345 of the Arts Building ${ }^{121}$ to give oral examinations together. [McGill students in French took both written and oral examinations.] If I am late, start without me, des Boys tells Pluche. Dubois warns Pluche that he must remember that des Boys never fails students. JAMAIS! The only exceptions are the occasional female students, but only if they are ugly as well as without relatives or protectors. A nice young girl has only to bat her eyes or weep-des Boys cannot resist the tears of a woman. And fortunately for the ugly ones, they usually work hard and are among the best students.

After Pluche has examined three students, des Boys shows up at 11:15 still sleepy. They quiz Kathleen McRaevity about the plays of François de Curel. Pluche has heard of McRaevity. With Joanna Marplot, the film censor, she is active in morality societies trying to shut down the red light districts. Miss McRaevity calls Curel "Curnival" (and "Carnival") and his "Le repas du lion" lei repast dou laieunn. Pluche's mind wanders while she delivers platitudes. Worse, he notices des Boys has fallen asleep and is snoring. Should Pluche wake him? Dubois had not warned him of this! When McRaevity starts talking about "Curnival de la Chausée," Pluche realizes she must be confusing Curel (1854-1928) and Nivelle de la Chausée (1692-1754). While Pluche wonders what she knows about the prostitution her group is suppressing, Miss McRaevity declares the hybrid "Curnival" wrote indecencies, about subjects which were unthinkable, she says lapsing into English. When she leaves, des Boys wakes up. Pluche asks: What did you think-Pas fameuse? That's just like you, retorts des Boys; it was fine, what she said, cette petite. But you, Pluche, vous n'êtes jamais content! Miss M. gets the top grade.

Messac sketches des Boys/du Roure's mannerisms deftly but (as this is satire) not his accomplishments. Du Roure built up the famous French Summer School and tenaciously lobbied the Dean of Arts for extra help for his overworked department. He advised the Consul General of France in Montreal on "Franco-Canadian questions connected with university and artistic work;" he wrote a survey on the teaching of French for the Protestant (English) School Board of Montreal in 1931 and, supported by Leacock, tirelessly advocated the establishment of a Maison française at McGill. ${ }^{122}$ And while du Roure did little scholarly publishing, he wrote several lively articles including an unfavourable review in 1922 of Lionel Groulx's nationalistic novel l'Appel de la race. Du Roure declared the novel encouraged racial discord, pointing out that one of the repentant FrenchCanadian hero's youthful crimes was that he had studied law at McGill, not a francophone university. ${ }^{123}$ Though he satirized du Roure, Messac liked the man who had hired him and had reason to be grateful to him. While des Boys frustrates Pluche, du Roure supported Messac's research in France by teaching his courses in October 1926 so that Messac could return late. ${ }^{124}$ Messac inscribed a copy of Le 'Detective Novel' to du Roure with melancholy but affectionate irony, recalling their teaching and examining together: "A Monsieur René du Roure / Hommage de l'auteur / In Memoriam / Régis Messac."125 And in its preface, Messac thanked "mon chef et ami M. René du Roure, qui m’a accordé toutes facilities au cours de mon travail...." Clifton Hall (M.A. McGill 1932) recalled du Roure: "was essentially a Parisian gentleman, his manners perfect, and always dressed with the greatest care.... A ray of sunshine from the Paris boulevards brightened the room as René came in bowing to his students, Bonjour, mesdemoiselles, messieurs. He preferred French writers of the sixteenth and seventeenth centuries to all others." 126 It was said du Roure died of a broken heart after the fall of France in $1940 .{ }^{127}$

\section{Les livres}

This chapter is about a subject dear to Messac-ordering books for the library. Pluche needs books for both his teaching and his research for his thesis. Pluche, like Messac, is writing a Ph.D. - but for Chicago and on a far more obscure topic than Messac's: "L'expression du lugubre dans Zschokke." [Messac's 
real thesis Le 'Detective Novel' has a brief reference to this German writer who set some of his fiction in America-New Orleans! Messac delighted in this sort of interplay between his real and fictional life.] Pluche has given des Boys a list of books to have the library order. They have not arrived. Why order books? asks Père Dubois; I prepare my courses with the encyclopedia. Des Boys apologetically pulls the forgotten list from his pocket. Pluche takes it to the library. The head Dr. Godwin is away at a librarians' conference but an assistant takes Pluche's list. She is immensely impressed; he has ordered even more books than Talkinghorse. The titles Messac has Pluche order reveal how closely Messac used real life details in his novel. Pluche asks the Library to buy "Hoxie Fairchild, The noble savage", "G.H. Luquet, la Religion des hommes fossils", "Ferand, Introduction à l'astronomie nautique arabe" and three other titles. Later he adds others including "Victor Hugo et Rosita Rosa" and "Victor Hugo spirite." The latter two related plausibly to the courses that Pluche/Messac taught-the others were rather esoteric and possibly to be checked for his Detective Novel thesis-or just seemed interesting. Of the ten titles specified in the chapter, eight had editions ca. 1925-1929 and appear in the catalogues of the Bibliothèque nationale de France; only the Hoxie Fairchild book is listed in the McGill Library catalogue today. At any rate, these book titles provided a jeu for Pluche-Messac interplay. ${ }^{128}$

In real life, Messac ordered books even more energetically than Pluche. Aided by the head librarian Dr. Gerhard Lomer, Messac requested the Library to purchase numerous works on French literature and other topics for his own thesis research and for reading by his students. ${ }^{129}$ Messac borrowed the books he ordered and others in the Library non-stop. In 2003 sixty-five books still had Messac's signature on the borrower's cards inside their covers - a fraction of what he read, considering this sign-out system had ended 40 years earlier and nearly all the cards had been discarded or lost as the paper slots holding them wore out. Of the books with surviving cards, signed out between 3 December 1924 and 27 April 1929, eight were by Balzac (Figs. 9\&10). Unlike Pluche, Messac devoted a course to him; Balzac figures largely in his thesis as well. Other titles show Messac's political or research interests, such as Joseph Reinach, Histoire de l'affaire Dreyfuss and a book by his thesis director Fernand Baldensperger. ${ }^{130}$ Messac borrowed books by Bulwer-Lytton and Anatole France, probably for the articles he published on them while at McGill. It is difficult to tell how many books Messac had the library order but of the 65 he signed out on the surviving cards, there are 17 which were acquired during his time at McGill and on which his signature was the first-an indication he may have ordered them. ${ }^{131}$ Besides books from the Library and borrowing detective novels from Professor Hermann Walter, Messac bought books by mail: the Assistant Bursar of McGill informed him of the arrival of some novels in December $1927 .{ }^{132}$ Likewise, writing to the Poe scholar Thomas Mabbott in 1928, Messac mentioned how hard it was to get periodicals which the McGill Library did not have, and how the inept Montreal booksellers had failed to get him a journal he wanted. ${ }^{133}$ Messac acknowledged Lomer's help in the preface to Le 'Detective Novel' and inscribed a copy to him: "To Dr Lomer as a testimonial of my gratefulness \& friendliness R. Messac."134

\section{Le Rah-Rah-Boy}

Prosper Doughnut, a student, is eating that most American concoction, a sundae-whipped cream, bananas, pineapple chunks, water melon, plums, figs and a date on top. Cherries, strawberries, almond chocolate and the aroma of vanilla, cinnamon and lemon complete the feast. Prosper symbolizes the mediocrity of Smith Conundrum. He belongs to every fraternity [Messac exaggerated, one could join only one], dines at the student cafeteria, spends his nights at clubs and never misses a match of baseball, football or hockey. He goes to church but only to highly recommended sermons. Prosper Doughnut prefers social life to lectures. He is a "cheerleader," chief of the "rah-rah boys," who lead the crowds in chanting "Rah-Rah" at university football games. Messac did not invent the term: the captions under the portrait of a member of the Class of 1927 referred to him as a "Rah-Rah Boy."135 Puritanical McGill refused to allow women cheerleaders, the bare-legged goddesses adored on more progressive campuses. Some unruly Smith Conundrum students dress up as sauvages, taking for their symbol a hirsute man on horseback - a "Hun" [the word for Germans used in the First World War]. The students identifying themselves as Huns do this for fun without knowing anything of Germany. Messac's Rab-Rah-Boy chapter had been published in 1930; Messac left its "Huns" unchanged in the 1942 novel-possibly as a gibe at the German occupiers of France.

"Rah-Rah" (from "Hurrah") was the university cheer everywhere- at rallies and football games all over North America. It appears in all student newspapers and the writings of Leacock and others. Messac must have heard and detested this expression of muscular exuberance daily but as usual had his fun with it as a symbol of American culture. The Smith Conundrum yell was:

Smith! Smith! Smith! S-M-I-T-H!

\section{SMITH!}

C-O-N-N-, conn, conn, conn!-Conn, conn, conn, conn, conn, conn!

N-U-N! nun! nun! nun!

Rah! Rah! Rah! [many times]

D-R-U-M, Drum! - Drum, drum, drum!

Conundrum, Conundrum, Conundrum! $!^{136}$

The real McGill Yell resembled that of Smith Conundrum:

M-c-G-I-L-L. What's the matter with Old McGill? 


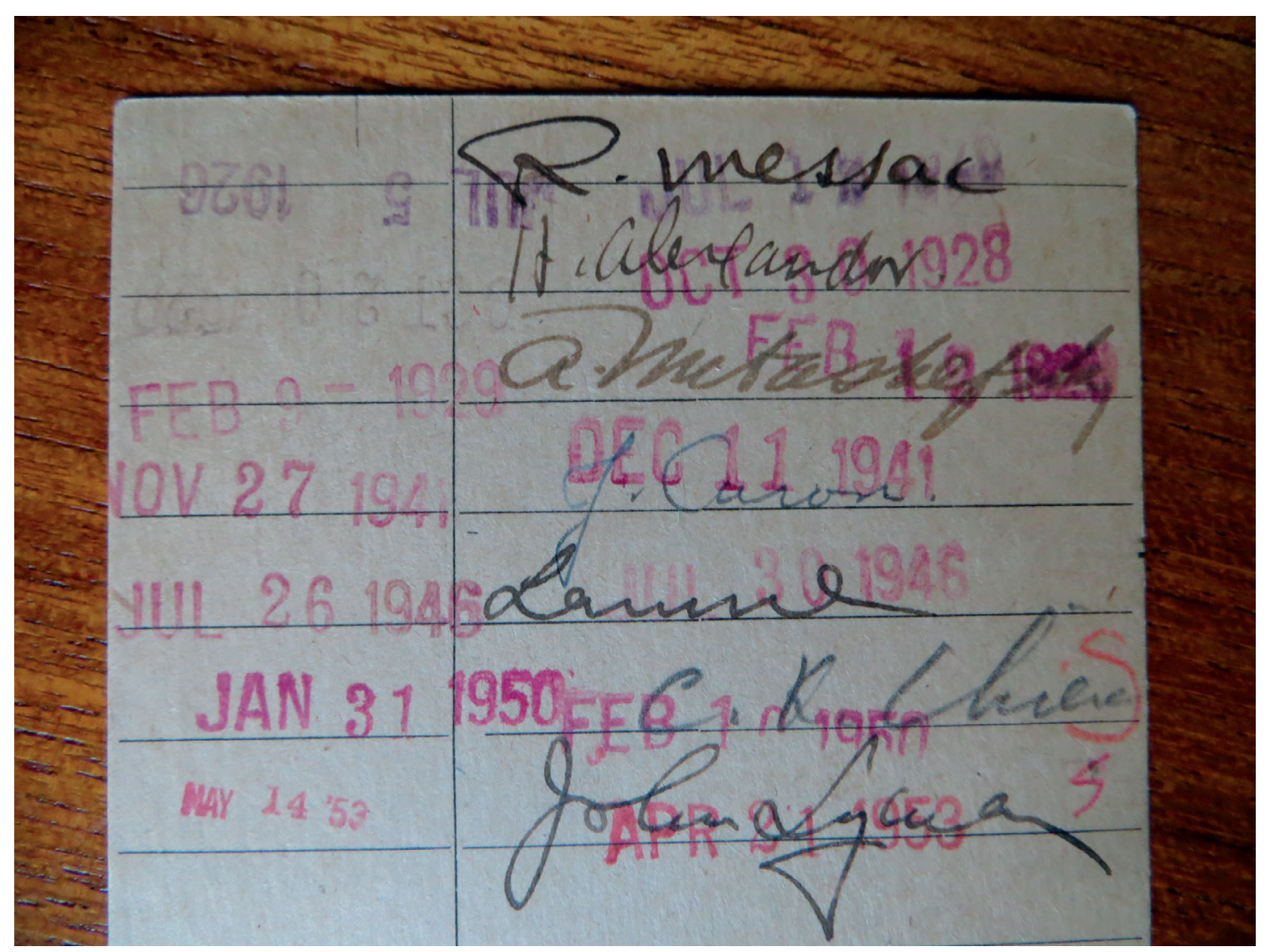

Figure 9. Les livres: Les Marana with Messac's signature, 5 July 1926

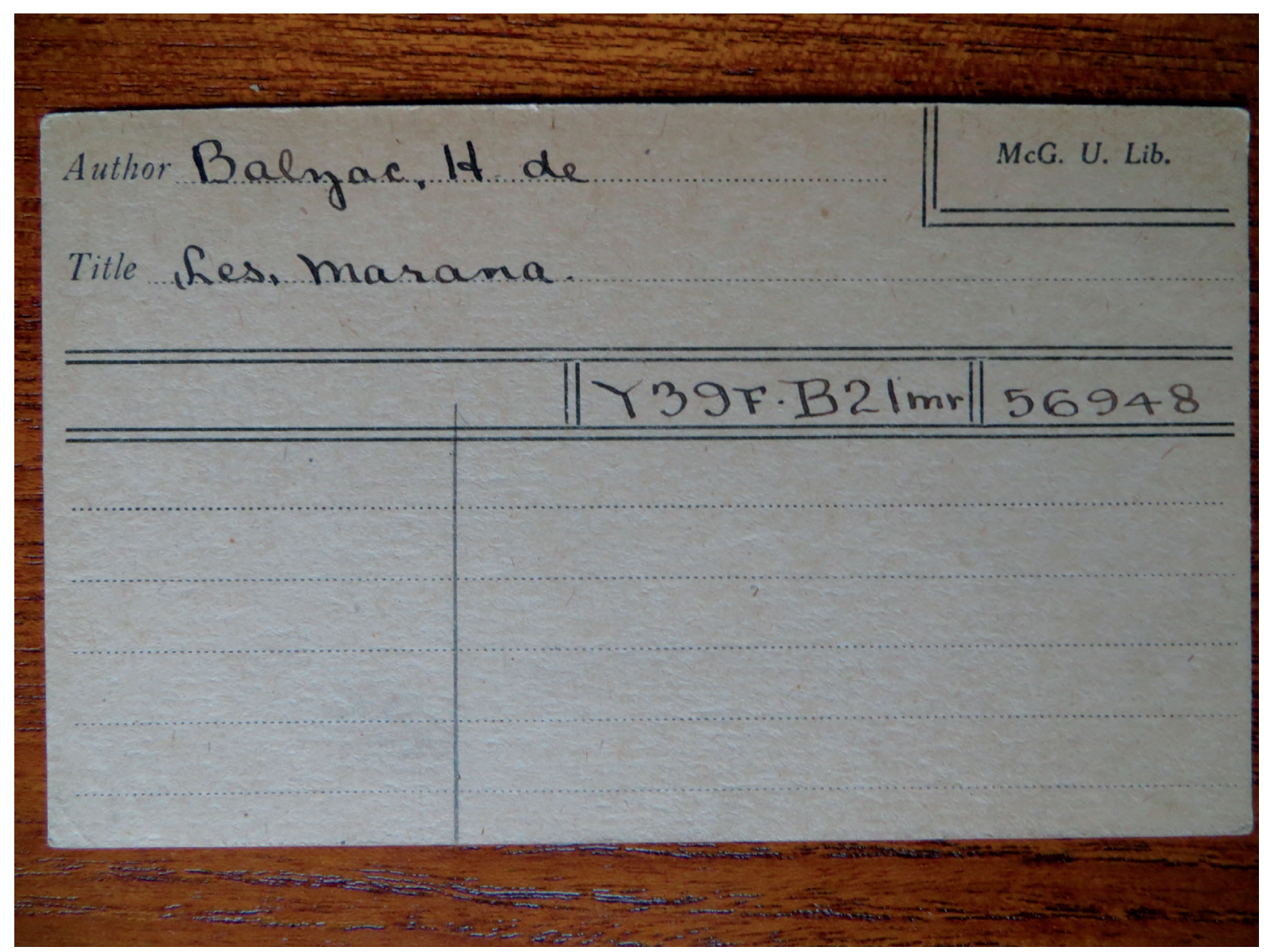

Figure 10. Les livres: borrower's card for Balzac 
She's all right, oh yes you bet!

McGill, McGill, McGill;

Rah, Rah, Rah! ${ }^{137}$

Prosper is distracted from his sundae by Ann Macdonell Pilgrim, the most beautiful of all co-eds. She wants a walk so he follows her to the campus. He adores her like a dog; he even walks her dog (Fig. 11). He ruins himself taking her to films, concerts, and buying her chocolates. The smell of acacias pervades the campus... Prosper's second year is nearly done... many students marry in their third year... Prosper blurts: I want you to marry me?... Say Ann, what d'ye think? Ann replies that she thinks she will marry Edgar Allan of the American Navy, a playful allusion to Edgar Allan Poe, who figured hugely in Messac's theses. She leaves Prosper alone. His two years at university weigh heavily and wasted. $\mathrm{He}$ stares mindlessly at his shoes which are the height of Chicago fashion [Chicago again!].

\section{Honoris Causa}

Starting here, the satire darkens and draws on actual McGill events rather than the more universal vignettes seen thus far. On 9 April 1926 McGill gave honorary LL.D. degrees to André

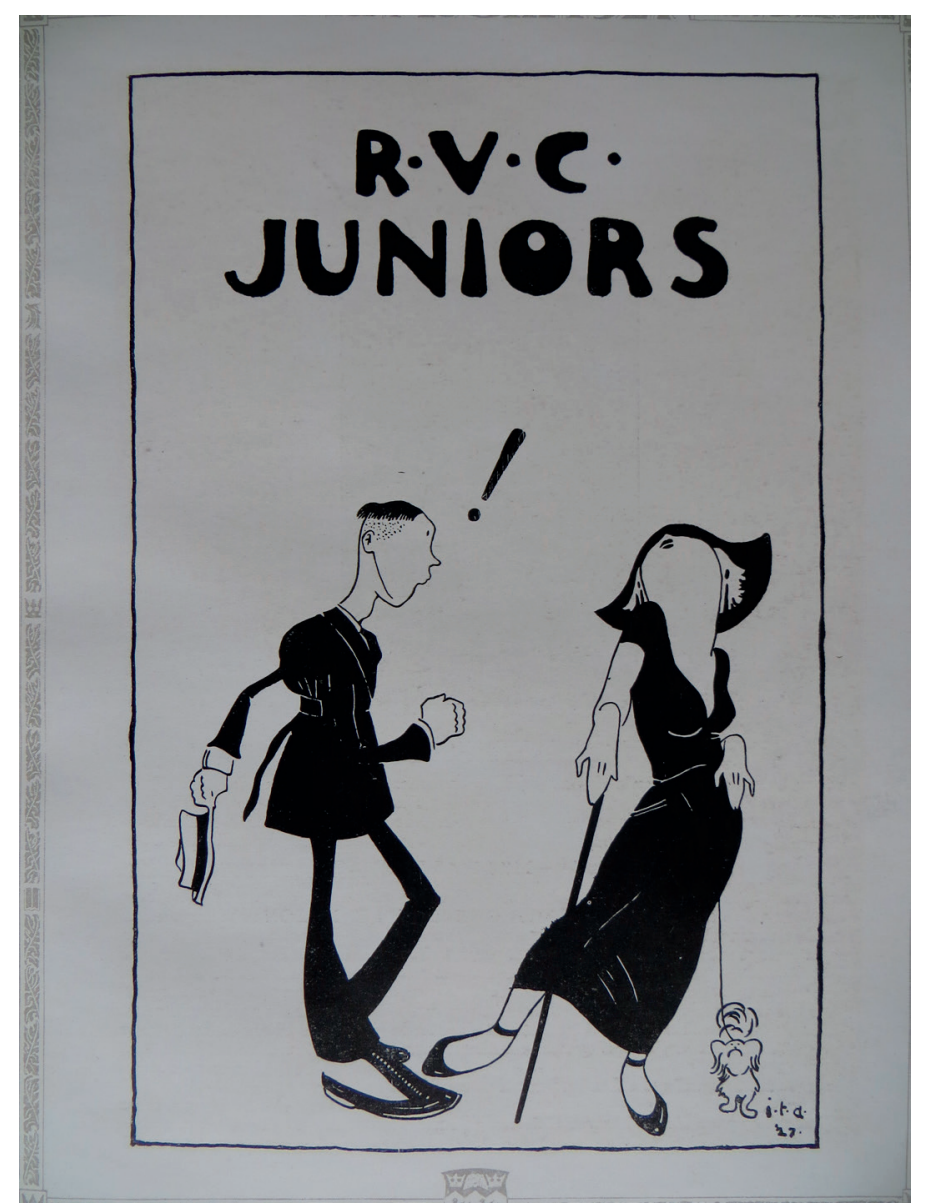

Figure 11. Le Rah-Rah-Boy: with Ann Pilgrim and her dog? Artist I.T. Archibald, B.Arch. 1928, Old McGill, 1927, 207
Honnorat (1868-1950) and the Duchess of Atholl (18741960), who were in Montreal attending an international conference on education (Fig. 12). Honnorat had founded the Cité Universitaire in Paris. Atholl was a Member of the British Parliament with education portfolios and was active in social reform. They were likely enough candidates for honorary degrees. Universities gained reflected glory by giving them; in a spectacular coup, McGill would award LL.D.s to Churchill and Roosevelt at the Quebec Conference in 1944. ${ }^{138}$ Not surprisingly, Messac deplored granting unearned degrees to anyone no matter how influential.

Addison, Lecturer in Greek, who besides Dubois and Eli Coil (seen later) seems Pluche's only intimate colleague, tells him the University will be giving honorary Doctor of Law (LL.D.) degrees to "l'honorable Honoré," a French senator and to an Englishwoman, "la vicomtesse Halloween." Addison smokes cigars and dreams of his Oxford past; he may have been inspired by a mixture of the Classics lecturer Paul McCullagh, just arrived at McGill in 1926 (graduate of Toronto not Oxford), who Messac knew through the Cercle Français, and the older, humorous, pipe-smoking William D. Woodhead, Professor of Classics, graduate of Oxford, Alberta and Chicago. Third and less likely may have been Oxonian Tommy Matthews (of Mathematics not Classics, who may have inspired Coil, seen later). ${ }^{139}$ Addison, Coil and the worldly Dubois are the ones who give the innocent Pluche the scoop on University machinations. Pluche is shocked that degrees are given unearned: "Honoris Causa! Vive l'Amérique! Plus d'examens, docteur en un seul jour!" The fictitious Honorable Honoré is a French Minister of Justice who had failed his law exams many times; Vicountess Halloween is being honored for her social work and research in women's prisons.

Pluche attends the special convocation with Addison in "Conundrum Hall;" the actual event took place in Royal Victoria College. [A.J. Roche and du Roure are listed in the Convocation records as attending. Messac is not listed; perhaps Roche told him about it.] Pluche is in rare good humour at the ridiculous "American" process of handing out unearned academic honours. "Nous allons honorer l'honorable Honoré," he alliterates. Colonel Artemus Dugout, the secretary of the Principal, General Rumblebass Balderdash, takes care of arrangements. $\mathrm{He}$ is based on Colonel Wilfrid Bovey, assistant to McGill's Principal, former General Sir Arthur Currie. [Bovey indeed was at the ceremony, directing protocol.] Now an immense building of a man makes his first appearance in the novel: General Balderdash himself. Pluche is told that the Balderdash was made a general because he looked the part; and since the Americans have no French Academy, after the war they made Balderdash a university principal. The dignitaries and professors march into the Hall. A newspaper account of the McGill event declared breathlessly: "The ceremony took place with full academic pageantry.... The gorgeous robes 

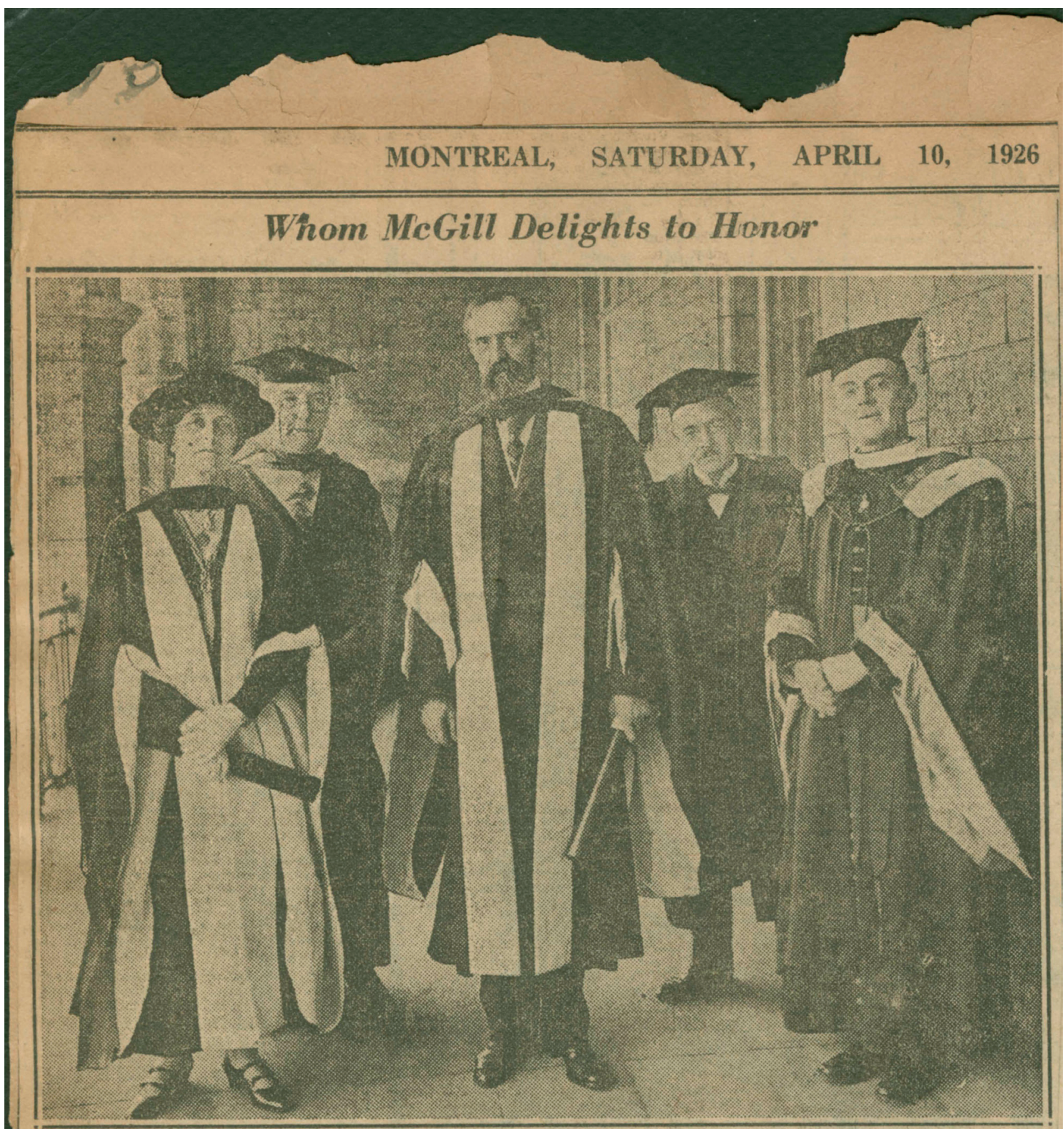

Left to right:-The Duchess of Atholl, M.P.; Miss Ethel Hurlbatt, warden of the Royal Victoria College; Senator Andre Honnorat, distinguished French legislator and founder of the Cite Universitaire, Paris; Prof. Rene du Roure, in charge of the French department at MeGil I University; and Canon Emile Chartier, vice-rector of th. University of Montreal, photographed after the special convocation of McGill University, held at noon yesterday, at which the Duchess and Senator Honnorat had conferr ed upon them the honorary degree of Doetor of Laws. Her Grace and Senator Honnorat are wearing the scarlet rohes and hoods of the doctorate. They were presented for the honor by Miss Hurlbatt and Prof, du Roure respe etively. Sir Arthur Currie, as Principal and Vice Chan. cellor of McGill University, conferred the degrees.

Figure 12. Honoris Causa: degrees for Atholl ["Halloween”] and Honnorat ["Honoré”], du Roure 4th from left, Montreal Star, 10 April 1926, MUA, McGill Scrapbook, Vol. 6 (1926), p. 130 
and hoods, signs of academic honors won from all the leading universities of the world, made a colorful setting...." ${ }^{140}$ Such trappings of academia made Messac - and Pluche - scoff.

Reverend Joshua Heluva, Dean of the College of Theology, invokes the blessing of the Lord of armies and professors. At the actual ceremony, it was Dean D.L. Ritchie of the Theological Colleges affiliated to McGill. Up front Pluche could see James Bunk, Dean of Graduate Studies, ochre skinned, face like a cubist portrait, luxurient white hair; he was completement gaga. As satirists simplify, usually unflatteringly, so Messac focused on the age of the real Dean, Robert Ruttan, who had taught Chemistry since 1886, had luxuriant white hair and was nearly $70 .{ }^{141}$ Balderdash confers the degrees. He speaks in a strange, garbled tongue. He is speaking Latin, whispers Addison. Strange, I learned Latin, says Pluche. Balderdash knows no Latin; he has memorized the formula: Ego admitto te ad gradum and so on. [Currie may not have known Latin but he made a good recovery once, when he gave some American scholar an honorary degree. The recipient replied with a short speech in Latin; Currie "rose splendidly to the occasion, stood to his full height... and said: "Pax vobiscum."142] In the Atholl/Honnorat ceremony, the head of Royal Victoria College, Ethel Hurlbatt gave the laudatory introduction for the Duchess, unparodied in the fictional account. ${ }^{143}$ But des Boys pompously praises Honoré in French; in real life du Roure honored Honnorat, also in French. Balderdash and Honoré babble uncomprehendingly at each other in English and French. The fictional Dean of Law, Jenkins W. Cattle, puts the scarlet robes on the recipients; the McGill Dean of Law, R.A.E. Greenshields, did the same for Atholl and Honnorat. The fictional account has "la Marsaillaise" and "God Save the King" sung; the real event had "Hail! Alma Mater!" and "God Save the King." Pluche tells Addison that they have watched ignoramuses honor one another. Addison replies "en Amérique, c'est ce que nous appelons a learned manifestation." 'This lone chapter was given an amusing translation by Gladys Quirk in $1975 .{ }^{144}$ To top things off, less than a month later McGill held yet another special convocation - to give an honorary LL.D. to Sir Esmé Howard, British Ambassador to the United States, who was in Montreal to address the Canadian Club on disarmament! $!^{145}$ But Messac already had more than enough ammunition from the Atholl/ Honnorat degrees...

McGill's reality and Messac's fiction and journalism in Le Progrès civique all intersect here. The honorary degree event had everything Messac hated: sycophancy, opportunism, debasement of academic degrees, and academic ceremonial. It inspired Messac's most bitter attack on "American" academia, particularly the market in honorary degrees. It was published a mere five weeks after the event, in Le Progrès civique (15 May 1926) in an article titled by that favorite American word "Bunk" [the name he also gave the Graduate Studies Dean]. He ridicules American susceptibity to charletans such as psychoanalysts. Any American institution could - and often did-call itself a college or university. ${ }^{146}$ America boasted it had the most university graduates but look at what they studied! He mocks Americans for elevating technical subjects to university programs. The University of Illinois had a magisterial chair in "swine husbandry." Chairs in crossword puzzles would be next. Messac cited Cornell with its Hotel School; Stephen Leacock would humorously predict in 1931 that one of the absurdities in McGill's future would be the installation in 1965 of "the first (Full) Professor of Hotel Keeping." ${ }^{147}$ Worst of all was the American practice of granting degrees honoris causa, for anything from giving a good sermon to giving money. Do you want to be a Doctor of Philosophy? Don't bother writing a thesis - get an honorary degree! He saved special bile for bible colleges, claiming the poorer religious universities sold honours for $\$ 50$. Such "Bunk" is just a form of lying-yet in time America doubtless will grow out of charlatanism. Europe too has its faults, he adds. The young culture serves as a model for the older, returning it to primitivism. The horror of the modern world is that men of merit must convince and fool others. ${ }^{148}$ In addition to his McGill experiences (what a store of criticism he built up there!), Messac may have been influenced by two furious critiques of American universities being ruled by monied interests, snobbery, and sports: Thorstein Veblen's The Higher Learning in America (1918) and Upton Sinclair's The Goose-step (1923).

\section{L'Académicien I, II, II, IV, V}

\section{I}

These five chapters are held together by the leitmotif of a new French professor, "1'Académicien," who lets people think he is a member of the French Academy when he is really "Officier d'Académie" - an honour given by the French government for services to education but which does not confer membership in the prestigious French Academy. However the Americans do not realize this! [In real life, Professors Villard and William Caldwell (Cadwallader Talkinghorse?) were officiers d'Académie - perhaps inspiring Messac's focus on this pretentious ambiguous title.] The chapters also send up McGill's prestigious, profitable French Summer School, held in July, directed by du Roure, in which Messac taught in 1925, 1926, and 1927. ${ }^{149}$ The "villain" of these chapters, L'Académicien, Léon de Ribassier de Pivres (hereafter Ribassier) gets a position at Smith Conundrum's "cours d' été" directed by des Boys. Messac may have taken the name "Ribassier de Pivres" from Mlle. Riballier des Isles, instructor in the Summer School in 1926 and 1927. When the chapters were published serially in Le Progrès civique in 1931, the brief editorial note promised readers that they would be astonished and surprized by this "amiable fantaisie qui permit de faire accepter les vérités les plus invraisemblables." ${ }^{150}$ 
Smith Conundrum gives its summer sessions in imitation of University of Chicago-Messac assigning yet another Chicago influence [the most important was on McGill's new Sociology Department]. ${ }^{151}$ In the novel the French Summer School is held in the Presbyterian College; in reality it was held there in 1925 while in 1926 and 1927 it mainly used the women's Royal Victoria College. As will be seen, the professor who inspired the Académicien was at McGill in Fall 1926 but Messac also mixes in real events of 1925 and 1927. Most of the French Department staff taught in the Summer School. The School gave beginner, intermediate, and advanced courses in the mornings with cultural activities in the afternoons; it was successful, made a profit and had an international reputation. In 1926, a typical year, the School ran from 28 June to 31 July, had 22 instructors, including the whole French Department and outsiders like poet Marie Le Franc, who left a brief description of the School's activities in a story. ${ }^{152}$ The summer staff included French Canadians, the Department dropping its prejudices for practical reasons, and Messac would have known the Quebecoise suffragette Idola Saint-Jean; she taught advanced diction, Quebec accent or not! There were 171 students ( 29 men, 142 women). The oldest was 60, the youngest 16; 116 came from the United States, 55 from Canada. Many students were teachers of French, a few working towards an M.A. Students pledged to speak French at all times, lived in residence, and ate together. ${ }^{153}$

The fictional, odd looking Ribassier, who changes his appearance at times, had arrived in Montreal with a French theatre company which got stranded. The women found work at the "Gayety," showing their thighs, with the prospect of earning 50 or 60 dollars a night en travaux supplémentaires. There was a real Gayety Theatre in Montreal, renowned for strip-tease acts. ${ }^{154}$ The men, like Ribassier, whose chief accomplishment is as a theatre prompter, must try to find jobs teaching French. Pluche thinks: the Gaiety for the women, teaching for the men: Chacun son genre de prostitution.

\section{II}

The summer students rehearse an abridged production of le Bourgeois Gentilhomme, a collaboration between Molière and "Mrs Gelb," a longtime teacher in the French Summer School and the French Department. She is modeled on Assistant Professor Lucie Touren Furness with whom Messac had cotaught courses in the regular session. Alice Sharples, who took French in the 1920s (B.A. 1923, M.A. 1925) recalled how important dramatics were for the French Department and how the bachelor du Roure and Touren Furness often acted together in local productions, such as those in the new Moyse Hall in the Arts Building, taking the parts of husband and wife in popular plays: "As in all French plays, either the husband or wife was unfaithful, or maybe it was both."155 Touren Furness married late in life but soon had two babies, in
1926 and ca. 1927. In the novel, Messac mischievously inflicts surprize pregnancy on the fortyish Mrs. Gelb. Molière might not have recognized Gelb's version of his play, which featured sensational dances by student Pixie Pickering: "Elle dansa avec tant d'ardeur que ses cuisses claquaient l'une contre l'autre...." The McGill Summer School actually performed le Bourgeois gentilhomme in 1927, with a dancer, to enthusiastic reviews. ${ }^{156}$

\section{III}

Des Boys asks Pluche to give a summer course on Balzac. Pluche declines, pleading his thesis. In reality, Messac gave a course devoted to Balzac but during the regular academic sessions in 1926-27 and 1927-28. The opportunistic Ribassier volunteers to give the course on Balzac. [No such course was given in the real Summer School.] Pluche hears Ribassier lecture on Balzac and ridicules his vocal mannerisms and lack of knowledge. But the students admire Ribassier and repectfully call him "L'Académicien." He is so profound, says Eleanor Whale, a blonde of 28 who looks 17 because she wears no makeup. The dancer Pixie Pickering avidly pursues him. She teaches him archery and pulls on his tie like a leash telling him "You are my pet dog!" Rich Eleanor and richer Pixie compete for Ribassier. Pluche fails to convince Pixie that Ribassier is not a member of the French Academy. Ironically she thinks Pluche is jealous that Ribassier is giving the course on Balzac.When she asks Pluche if Ribassier realizes she is richer than Eleanor, Pluche plots mischief: Count on me. I'll tell him.

\section{IV}

Summer School ends and prizes (as at McGill) are distributed by French officials while the Marseillaise plays-clues that we are not in a typical American university. In Messac's time, the French consul, Vitrolles, and representatives of the Alliance Française gave awards to the best students. Eminent speakers came to the ceremonies: Athanase David in 1926. $\mathrm{Du}$ Roure worked with Athanese David on legislation to encourage literary and scientific work in Quebec. Du Roure also had been appointed with Currie's support by the French government to be Délégué Universitaire to the French consulate in Montreal. ${ }^{157} \mathrm{Du}$ Roure and Villard had prestigious ties with the French consulate and the Alliance Française-more fuel for Messac's satire. Fall term arrives. Mrs. Gelb will soon have her child and must be replaced. [In real life Touren Furness married in 1924; with du Roure's support, she persuaded Principal Currie to keep her on as McGill's first married woman professor. ${ }^{158}$ ] Won't Mrs. Gelb be replaced? asks Pluche. No, Smith Conundrum is humanitarian; it will keep her on, says Dubois - we will all have to share the extra teaching. What about my thesis, cries Pluche; we must replace her! What is Ribassier doing now? He was alright for the Summer School, replies Dubois but he 
won't do for the regular sessions. He is no worse than Mrs. Gelb and her play, retorts Pluche. So Ribassier gets hired for the regular session. He had fraudulently convinced Principal (and former General) Balderdash that he had known General Joffre during the war. Now he is under Balderdash's protection. By now everyone calls Ribassier le marquis in addition to officier de l'Académie française. He teaches medieval literature and makes a great hit with the students although he is incompetent. He has even gotten himself promoted to Associate Professor, a rank Dubois has failed to get for years!

\section{V}

Pixie Pickering returns to pursue Ribassier. She and Eleanor Whale argue over what kind of ribbon decoration Ribassier is entitled to wear as an Académicien (a subject guaranteed to raise Pluche/Messac's bile). Pluche matchmakes, telling Ribassier how rich Pixie is. Christmas vacation comes, Pluche is locked up with Zschokke. When the new term starts in January, Ribassier has disappeared. So has Pixie. Des Boys opens a letter from him: "Unforseen family business has forced me to leave suddenly." When you read this I will be on the Atlantic. Next a telegram arrives from an ocean liner. Ribassier and Pixie have married on board. Pluche observes that Ribassier has struck it rich. Des Boys declares, we will all have to take over his courses. Has Pluche's playful abetting of Ribassier's romance backfired? Everyone protests. Except Dubois. He will do the extra teaching... in return for promotion to Associate Professor! [Perhaps Messac had heard that it had taken Villard a long time before being promoted to Associate in 1924.] Pluche smiles, shrugs and goes away.

Messac's French Summer School experience closely resembled Pluche's. In July 1927 Messac lectured on Anatole France to his largely American female class, having just published "Anatole France vu par les américaines" in Le Progrès civique in April 1927-as usual his research fueled both his teaching and publishing. In his three summers at the School $(1925,1926,1927)$, Messac also taught the contemporary French novel, history of France 1815 to present, and literary criticism. As seen, he drew on Touren Furness, Villard and du Roure for the novel's Summer School episodes. Ribassier is Messac's most prominent character after Pluche, des Boys and Dubois. While the latter three resemble their inspirations, it is impossible to say if Ribassier, "l'Académicien," is even a remotely accurate portrait of either man suggested below as his original-feckless and on the make, he even may be a composite of everyone Pluche/ Messac mistrusted at University.

For his character Ribassier, Messac borrowed from the circumstances surrounding the brief career of Laurence Adolphus Bisson (1897-1965) in the McGill French Department in Fall 1926. As with du Roure and Villard, one assumes Messac changed, simplified and "improved" Bisson for satirical purposes. Bisson did not teach in the Summer School nor as far as is known was he an officier d'Académie. In the novel, Ribassier is under the Principal's protection. In real life, Bisson had good references; Principal Currie interviewed him and appears to have hired him in April 1926 as Assistant Professor for one year. ${ }^{159}$ At this period, the Principal often was involved in choosing and hiring academic staff, usually in consultation with Heads or Deans. While Ribassier filled the vacancy left by Mrs. Gelb, in real life Bisson replaced Messac's colleague André Roche, who went on to a distinguished career at St. Francis Xavier University. Born on Jersey, bilingual with a French mother, educated at Pembroke College, Oxford, Bisson was working toward a Ph.D. at the Sorbonne (which apparently created no bond with Messac) and taught at University of Toronto before McGill. In Messac's rendering, the similarities between Ribassier and Bisson are numerous if circumstantial. Ribassier offers to teach medieval literature-Bisson would later publish a text which included medieval literature (1943). Ribassier courts his students' favour-Bisson told the Daily he preferred McGill students over his former ones at Toronto as they were better prepared in French. ${ }^{160}$ Bisson had worked for the League of Nations - a source of prestige like Ribassier's officier d'Académie title. To complete his League work, Currie allowed Bisson to report slightly late [by 5 October ] in $1926 .{ }^{161}$ Currie had also agreed with du Roure that Messac too could return at the very end of October 1926, so French was briefly shorthanded-this may have caused friction. It may be speculated that Bisson gave a few weeks of Messac's honours course on Balzac that October until Messac returned. If so, this may account for Pluche's contempt for Ribassier's teaching of Balzac. Moreover, Bisson became ill in November 1926 and du Roure, while sympathetic, pointed out it to the Dean that it was impossible for him, aided by Messac and Touren Furness to fully cover his courses. ${ }^{162}$ Both Ribassier and Bisson quit without notice at Christmas (Bisson probably due to illness). Currie had to tell the Board of Governors Finance Committee that Bisson had left without giving any reason and that a replacement had been engaged. ${ }^{163}$ As with Ribassier in the novel, Messac and the others could not add Bisson's classes to their own workload so a replacement, Louis d'Hauteserve, had to be found quickly. Messac spun all this into the tale of Ribassier's elopement to Paris with Pixie Pickering. Whatever caused Bisson to leave, he ended up in England where he was a solid scholar. ${ }^{164}$

Ribassier had taught at the Summer School previous to his Fall term. Bisson had not. In the novel Ribassier is promoted to Associate; in real life Bisson remained an Assistant like Messac, while Villard, unlike Dubois, already had been promoted to Associate. As a final wrinkle on Messac's possible inspirations for l'Académicien and one which involved the summer school, Edouard Sonet (1880-1971) may be cited. Born in France, Sonet taught French at University of Alberta from 1911 to 1947 . He was highly recommended to Principal 
Currie to teach in the 1927 McGill French Summer School. Sonet (like Messac) was attracted by McGill's well stocked Library. Currie passed the recommendation to du Roure who replied that the 1927 staff was already complete but a position might become available for Summer 1928. Currie reported to Alberta that Sonet was on the list for 1928. But in June $1928 \mathrm{du}$ Roure wrote Currie that his recollection of their "conversation" was that he would take Sonet only if a vacancy came up and that he had notified Sonet in December 1927 there was still no vacancy:

It is true that later on after my letter, Professor Messac told me that owing to his research work, he must spend the summer in France. I did not offer this vacancy to Professor Sonet, because of a complication that I would rather explain to you verbally. ${ }^{165}$

It is unclear what the "complication" was and whether it involved Messac. At any rate, Messac may have been thinking of Sonet as well as of Bisson in this complicated chapter. What seems certain is that Currie had again, as in the case of Bisson, sponsored a candidate to the French Department and du Roure and Messac may have resented it.

\section{La Bataille de Tipperary}

Here Messac targets Principal Currie, the inspiration for Principal Rumblebass Balderdash. ${ }^{166}$ Messac's distrust of Currie was inevitable, since Currie personified McGill when Messac taught there. Currie was the war hero leader of Canadian troops; Messac was anti-war. Currie and Balderdash represented hierarchical authority, had no academic qualifications and were admired by what Messac and Pluche considered to be a toadying staff. Currie opposed socialist views among staff and students, although he tended to be cleverly flexible in dealing with political opposition and critical student publications like the McGill Fortnightly Review. Currie and Lord Byng of Vimy, Governor General of Canada, 1921-1926 ("Lord Pyff of Tipperary" in this chapter) had won the Canadian victory of Vimy Ridge (April 1917); Currie would later be criticized for losing lives taking Mons at the war's end, 10-11 November 1918 (Fig. 13). Messac expanded these two engagements into the fictive battle of Tipperary, Balderdash commanding, in which 15,000 Americans died for the sake of glory on the last day of the war. In 1927 an Ontario newspaper claimed Currie had wasted lives taking Mons on the last day. Currie sued for libel and in April 1928, as the school year ended, Messac followed the libel trial along with the rest of McGill.

The professors drift in and out of the Arts Building's common room discussing the case. Pluche chats with Eli Coil, a young newly hired mathematics instructor (inspired perhaps by Tommy Matthews, born in 1891, hired in 1920, of Mathematics or the young Paul McCullagh, born in 1903, hired in 1926, of Classics not Mathematics ). ${ }^{167}$ Coil tells Pluche about Balderdash's undistinguished pre-war career and how he wasted 15,000 lives the final day. What do the French do with generals after the war? asks Coil. We make them members of the Academy. We don't have that in America, says Coil, so we made Balderdash a university principal-the same observation occurs in Honoris Causa. At the moment, the trial is going against Balderdash. In cinematic style, bulletins come in by telephone. A professor in his sixties arrives: Julius Werther, in Pluche's eyes, one of Smith Conundrum's rare scholars. He has helped Pluche with his thesis. In real life, this was Hermann Walter, head of German, who lent Messac books for his thesis. ${ }^{168}$ Currie had suspended Walter during his dispute with J.L. Morin mentioned above, another reason for Messac to dislike Currie. Some professors congratulate Werther; soon his old enemy Balderdash may be ousted if he loses his case. Now it is Addison who tells Pluche Werther's story: Werther was openly atheist; a Protestant clergyman [Morin indeed was a Protestant cleric] had poisoned his well. After three years of

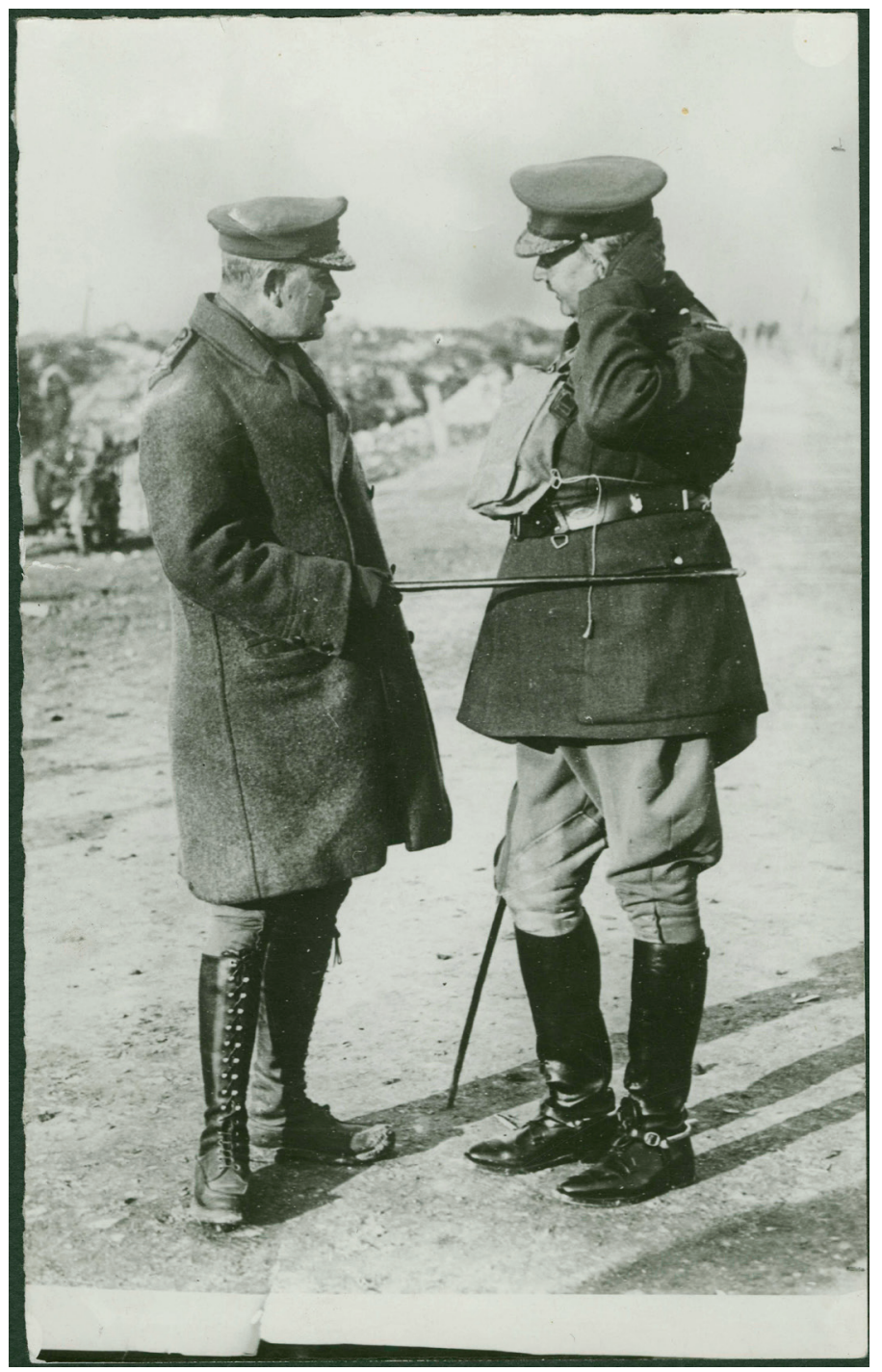

Figure 13. Tipperary: Sir Julian Byng ["Pyff"] (L) and Sir Arthur Currie ["Balderdash"] at Vimy Ridge, 1917, photographer unknown, MUA 00000481.04 .316 
litigation, the court blamed Werther not the poisoner [in real life, no guilt was proven although the aged Morin soon had to resign]. Why? asks Pluche. Replies Addison: we AngloSaxons always condemn the victim. Why? To spare the feelings of the criminal, who is already suffering from guilt. Balderdash, a fervent Protestant, had tried to fire Werther but failed [in real life Currie had suspended first Morin then Walter as the court decisions went back and forth; Walter emerged victorious as head of German, du Roure fortuitously as head of French].

As the news of the trial shifts, Dubois goes back and forth among the groups of professors. They are all sniffing the air. Will Balderdash win or lose and possibly be deposed as Principal? Pluche says it is like a play. Finally Balderdash wins but is awarded only a 1/100,000 of what he demanded in damages [in reality Currie won 1/100 of what he asked: $\$ 500$. against $\$ 50,000$ ]. Still, Balderdash [like Currie] was vindicated. Colonel Artemis Dugout [based on Wilfrid Bovey], Balderdash's right hand, appears. Led by Dubois, the professors rush to Dugout to subscribe to a victory dinner for the triumphant Principal. The General has won again, muses Pluche. Addison whistles "It's a long, long way to Tipperary." When Currie returned from the trial to McGill on 2 May 1928, bands played and a cheerleader-Prosper
Doughnut? - led the students in the McGill yell: Rah-RahRah! Most McGill professors and students admired Currie. Messac stayed in touch with Walter, perhaps the only McGill professor he admired, writing him a congratulatory letter on Walter's biography of Heine in $1931{ }^{169}$

\section{On rentre}

This is Pluche/Messac's testament, the sad yet liberating chapter, in which Pluche decides to leave Smith Conundrum. Pluche begins his fourth year. It is October, the only time when the campus is beautiful. The leaves turn colour, the trees mask the ugly buildings [the buildings were admired by most McGill staff, including Leacock ${ }^{170}$ ], the students greet Pluche and one another, coeds wear new outfits, professors old gowns... But Pluche, melancholy, wanders the campus. The Arts Building janitor, red faced, deferential, asks him him if he enjoyed his holidays and gives Addison a parcel. Pluche asks Addison if he has noticed how important university janitors are; they render services, know everything, and are more indispensable than the Dean. [The Arts Building janitor, Bill Gentleman was beloved by all, as was janitor-poet Harry Barker, and others.] Addison declares that the janitors are the only people with whom the professors can feel important.

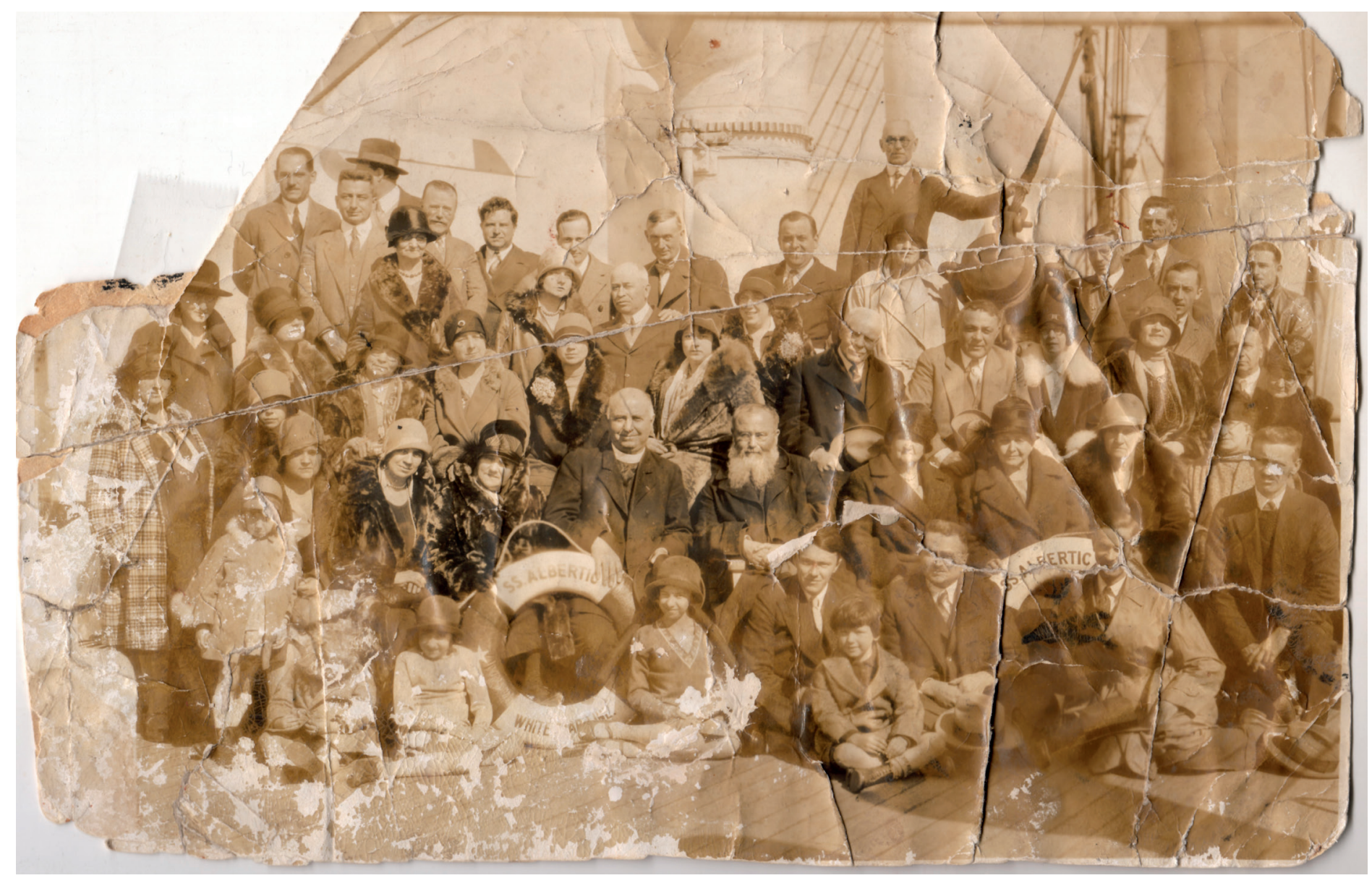

Figure 14. On rentre: Messacs returning to Montreal for last time, Sept. 1928, on S.S. Albertic. Germaine and Ralph, front, extreme left, Serge seated foreground, Régis, last row, 5th from left. Photograph: Canadian National Railway, courtesy O. Messac, Paris 
The students are younger, richer and socially superior while the Principal, Deans and wealthy Governors can fire them at will. Addison muses : we professors are " $a$ kind of higher club servants... subject to dismissal just like servants."

Pluche gives his lecture in a trance. He walks on campus again, passing billboards announcing lectures. Gladys P. Winegar of the University of Nebraska, "Ph.D. in Euthenics," will be lecturing on "The bacterial contents of Undershirts." Here is another example of Messac using real life quite literally-a researcher, Gladys Winegar, from University of Nebraska, did indeed write, A Study of the Bacterial Content of Cotton Undershirts (Kansas State Agricultural College, 1927, 106 pages)!171 This epitomized the lowly subjects of "American" university scholarship for both Pluche and Messac. Another poster invokes the bête noire of religion: a sermon by Nathanielson Clothesline on "The several roads to hell." Next the military: Pluche sees a recruiting poster for reserve officer training by "Colonel Martlet," in real life Colonel Stuart Forbes, war hero and Director of Athletics and cadets. The martlet is McGill's symbol-a bird without legs. Messac may have known that Forbes loved sketching this bird for heraldic decorations. Pluche mutters to himself that Winegar and Clothesline are charletans, then asks how he differs from them. People want their learning more than his. Who cares about French literature? It is only on the curriculum out of tradition, of no use to future businessmen. Cadwallader Talkinghorse appears. Muses Pluche: that's whom everyone admires; the students quote him in the Daily ${ }^{172}$ but he cowtowed like the others during the "Tipperary" trial.

Recalling Addison's remark, Pluche realizes he is indeed just a servant. The powers that be support the Ribassiers and the Talkinghorses not him. Money rules in America. Here the novel echoes Messac's articles in Le Progrès civique. Promotions and raises go to adventurers like Ribassier and the time-serving Dubois. Pluche recalls his recent request to des Boys for an increase. Wait a bit, he was told. The University is planning a campaign - the bankers will give $\$ 10$ million, but times are hard at the moment. ${ }^{173}$ [McGill's planned funding campaign was cancelled by the Depression of 1929 . Ironically, Du Roure managed to get small increases for staff soon after Messac left. ${ }^{174}$ ] Pluche realizes the University is a luxury, supported only when the bankers have surpluses. He has gone in a circle; he is back at the Arts Building and the founder's urn. He walks quickly, firmly to his apartment and writes a polite letter to the Board of Governors stating that he will not have the honour of being on staff the next academic session. ${ }^{175}$
Another Frenchman abroad whom Messacmayhaveknown from University of Glasgow, Michel Poirier, taught French at University of Toronto. In May 1928 he commiserated with Messac. He too was frustrated by low pay and superiors he found incompetent. He was sorry to hear Messac's health was suffering and that his teaching and research were exhausting him. ${ }^{176}$ The Messacs visited France for final research in the summer of 1928, sailing back that Fall (Fig. 14). By then Messac like Pluche may have decided to leave McGill after this, his final year. We may assume that like Pluche he was disatisfied with his pay, the academic hierarchy and poor academic standards, although his relations with colleagues appear to have been unruffled and his criticisms internalized in the novel he was starting. By 24 January 1929 Messac had resigned. The tragic death of the Messac's newborn, third son Francis, who lived from 4 February to 28 February 1929, was not the cause of their leaving as has been supposed. ${ }^{177}$ He had his thesis to present to the Sorbonne and a career in France ahead. He requested re-integration into the French university system and taught at lycées but never held another university position, probably because of his leftist, contrarian views. He continued to write furiously on everything from marriage to war-always from a secular, anti-religious, antitraditionalist, anti-bourgeois, anti-militarist, non-violent, non-nationalist viewpoint. The Gestapo arrested him in May 1943 for helping the Resistance (non-violently) and he was afterwards taken away Nacht und Nebel and died in Germany early in $1945 .{ }^{178}$

Messac took Harry Swellhead, Goldye Belemnith, Talkinghorse, Dubois, des Boys and Balderdash back to France for his novel. At McGill, he left the traces we have seen in the archives and publications. This witty young teacher must also have left a feeling of loss in some of his colleagues and students. His five years in America seem neither long nor short. Reporting on the French Department in 1929, Dean of Arts Ira MacKay found it just passable and recommended that the head [du Roure] should be replaced by someone who would be more "socially intimate with his staff" and would keep them at McGill-perhaps referring to the loss of Roche, Bisson, and most recently Messac. But du Roure [and des Boys] led charmed lives and endured, as Messac [and Pluche] affectionately realized they would. "I deeply regret the loss of Professor Regis Messac," continued the Dean. "He is a fine scholar, but I fear that his place is in a University in his own country." ${ }^{179}$ This was Messac's epitaph at McGill. He never joined the circle of contented, aging professors sipping whisky in the Faculty Club bar. But McGill provoked him; he brewed his ideas there. Later he would face a world far worse than "An American University." 


\section{Appendix: Cast of Characters of Smith Conundrum with McGill Inspirations}

\section{Smith Conundrum University $\quad$ McGill University}

\begin{tabular}{|c|c|}
\hline In alphabetical order by last name: & Definitely inspired by, with some real life similarities: \\
\hline Balderdash, Rumblebass. Principal & Principal Sir Arthur Currie (1875-1933) \\
\hline Chicago Professor ("un professeur de Chicago") & Stephen Leacock (1869-1944). Economics \& Political Science \\
\hline $\begin{array}{l}\text { des Boys de la Tour, Vicomte. Chef, Dépt. Français } \mathcal{E} \text { cours } \\
\text { d'été }\end{array}$ & $\begin{array}{l}\text { René du Roure (1881-1940). Chairman, French Dept. \& } \\
\text { French Summer School }\end{array}$ \\
\hline Dubois, Père. Dépt. Français E cours d'été & Prof. Paul Villard (1867-1952). French Dept. \\
\hline Dugout, Colonel Artemus. Secrétaire du Principal & Colonel Wilfrid Bovey (1883-1956). Assistant to Principal \\
\hline Gelb, Mrs. Dépt. Français E cours d'été & $\begin{array}{l}\text { Mrs. Lucie Touren Furness (1887-1974). French Dept. \& } \\
\text { French Summer School }\end{array}$ \\
\hline Godwin, Dr. Librarian & Dr. Gerhard Lomer (1882-1970). University Librarian \\
\hline Halloween, Vicomtesse & Duchess of Atholl (1874-1960). M.P. (United Kingdom) \\
\hline Honoré, l' Honorable & André Honnorat (1868-1950). French Senator \\
\hline $\begin{array}{l}\text { Pluche, Prof. André J. (Protagonist). Dépt. Français E cours } \\
\text { d'été }\end{array}$ & $\begin{array}{l}\text { Prof. Régis Messac (1893-1945). French Dept. \& French } \\
\text { Summer School }\end{array}$ \\
\hline Pyff, Lord & Lord Byng of Vimy (1862-1935) \\
\hline Ribassier de Pivres, Léon de. Dépt. Français \& cours d'été & $\begin{array}{l}\text { Prof. Laurence A. Bisson (1897-1965). French Dept. possibly } \\
\text { with elements of Edouard Sonet (1880-1971), French Dept., } \\
\text { Univ. of Alberta }\end{array}$ \\
\hline Smith Conundrum. Fondateur, Smith Conundrum University & James McGill (1744-1813). Founder of McGill University \\
\hline Snuffbox, Alexander. Dépt. Histoire & William T. Waugh (1884-1932). History Dept. \\
\hline Werther, Julius. [Unnamed dept.] & Prof. Hermann Walter (1863-1952). German Dept. \\
\hline
\end{tabular}




\begin{tabular}{|c|c|}
\hline & Possibly inspired by: \\
\hline Addison. Dépt. Classics & $\begin{array}{l}\text { ? Mixture of Paul McCullagh (1903-1999), and William D. } \\
\text { Woodhead (1885-1957), both of. Classics Dept., and Tommy } \\
\text { Matthews, (1891-196?). Mathematics Dept., later Registrar }\end{array}$ \\
\hline Coil, Eli, Dépt. Mathematics & $\begin{array}{l}\text { ? Mixture of Tommy Matthews (1891-196?). Mathematics } \\
\text { Dept., later Registrar, and Paul McCullagh (1903-1999), Classics }\end{array}$ \\
\hline \multirow[t]{2}{*}{$\begin{array}{l}\text { Talkinghorse, Cadwallader H. Parsley Prof. of Ethics and } \\
\text { Moral Philosophy }\end{array}$} & $\begin{array}{l}\text { ? Dr. William Caldwell (1863-1942). Macdonald Professor of } \\
\text { Moral Philosophy }\end{array}$ \\
\hline & Positions match, little other detail: \\
\hline Bunk, James J. Doyen de la Faculté de Graduate Studies & Robert Ruttan (1856-1930). Dean, Graduate Faculty \\
\hline Cattle, Jenkins W. Doyen de la Faculté de Droit & R.A.E. Greenshields (1861-1942). Dean, Law Faculty \\
\hline Heluva, Joshua. Doyen du Collège de Théologie & $\begin{array}{l}\text { David L. Ritchie (1864-ca.1960). Dean, Theological Colleges } \\
\text { affiliated to McGill }\end{array}$ \\
\hline Martlet, Colonel. Directeur, Compagnie-école de cadets & $\begin{array}{l}\text { Colonel Stuart Forbes (1889-1965). Director of Athletics \& } \\
\text { Canadian Reserve Officer Training }\end{array}$ \\
\hline $\begin{array}{l}\text { Quartier de Montrouge, Marquis du. Attachéau consulat } \\
\text { de France }\end{array}$ & $\begin{array}{l}\text { Baron Régis de Vitrolles (18??-19??). French Consul, Montreal } \\
(1923-1928)\end{array}$ \\
\hline
\end{tabular}




\section{Acknowledgements}

I owe thanks above all to Olivier Messac for frequently answering my questions with valuable information about his grandfather Régis Messac, and for sending me copies of Régis Messac's correspondence, photographs, articles, and republished books, several of which are cited here. I am also grateful to Marc Angenot, holder of the James McGill Chair of Social Discourse Theory, McGill University, for sharing comments on Messac and Smith Conundrum; at the McGill University Archives to Gordon Burr, Senior Archivist, for much assistance over the years, Bruce Dolphin, Mary Ellen W. Houde, David Poliak, Theresa Rowat, Director, for careful help with photographs, and Jean-Marc Trembley; staff and volunteers, especially Kelly Walsh, of Atwater Library and Computer Centre, Montreal; Anne Garrison, McCabe Library, Swarthmore College; Kathleen MacKenzie, Archivist, St. Francis Xavier University; Greg Prickman, Head, Special Collections \& University Archives, University of Iowa Libraries; Moira Rankin, archivist, University of Glasgow; Carl Spadoni, Director, William Ready Division of Archives and Research Collections, McMaster University; Joel Natanblut, Digitization Administrator and Amy Buckland, eScholarship, ePublishing \& Digitization Coordinator, McGill Libraries; Alice Messac, Carol Wiens and Nancy Walkling.

\section{ABREVIATIONS}

\section{MUA McGill University Archives}

MG Manuscript Group (private fonds)

RG Record Group (administrative fonds)

C Container

RG2 Records of the Principal (McGill)

RG7 Records of the Registrar (McGill)

RG32 Records of the Dean of Arts (McGill)

RG49 Records of the Information Office/Public Relations (McGill)

\section{ENDNOTES}

${ }^{1}$ A much briefer version of the topics covered here is my Postface to Smith Conundrum, Éditions ex nihilo, Paris 2010. The present article joins my others in Fontanus on McGill's portrayal in fiction and memoir: "Floreat Plutoria: Satirical Fiction about McGill," Fontanus, IX (1996); “The Gates of McGill: an Unpublished Novel of the 1920s by Dink Carroll," Fontanus, XI (2003); "Adversity Vanquished: Memoirs of a McGill Medical Student, Harold W. Trott, 1918-1924," Fontanus, XII; and "Fiction, Faction, Autobiography: Norman Levine at McGill University, 1946-1949," Fontanus, XII.

${ }^{2}$ Library and Archives Canada (LAC), Department of Immigration and Colonization, Border Entry Records. The records (Forms 30 and 30A) of the Messacs' arrival and their acceptance as landed immigrants on 3 October 1924 are on Microfilm Reels, T-15,127 and T-15,309. There are two copies of Form 30A, one all in Messac's handwriting, the other partly typed at the beginning but mainly in Messac's handwriting. Another form (paginated 18,721 - the rest of the forms did not have page numbers) titled "Particulars When Family Accompanying" was signed by Messac but typed, presumably by an official. It is stamped "Guided." Under remarks it is noted that Messac "is going to teach French at McGill University for three years, and if possible will likely make his permanent home in Montreal." Immigration records 1925-1935 are digitized and indicate that Régis, Germaine, Serge and Ralph re-entered Canada on 31 Oct. 1926 (arrived at Quebec on S.S. Alaunia (Cunard). On 21 Sept. 1928, Régis, Germaine, Serge and Ralph sailed from Le Havre, re-entering at Quebec on S.S. Albertic 29 Sept. 1928. They had left Montreal 30 May 1928. The references to the Messacs in 1926 \& 1928 are Immigration Records, 19251935, RG 76-Immigration series C-1a: microfilm reels T-14,729, 1926 volume 23, p.5, and T-14,749, 1928, volume 26, p.130. In 1928 Messac, perhaps with sly humour, gave his employer as Sir Arthur Currie, Principal of McGill University. Unlike the crossing of 1924 , this passage ( $3^{\text {rd }}$ class) was paid by Messac. The 1928 record includes Messac's middle name: Gilbert.

${ }^{3}$ Email, Olivier Messac to Robert Michel, 22 mai 2011; 12,13,14 July 2012. Germaine inscribed a copy of Fleurs du mal to Régis in 1918 on her $27^{\text {th }}$ birthday to the effect: why marry when we please each other thus.

${ }^{4}$ Mainly by Éditions ex nihilo, Paris, under the general editorship of Messac's grandson Olivier Messac.

${ }^{5}$ Natacha Vas-Deyres and Olivier Messac, eds., Régis Messac: un écrivain journaliste à re-connaître, Éditions ex nihilo \& Université Michel-deMontagne-Bordeaux3, 2011.

${ }^{6}$ Messac was appointed at the (low) level of assistant for 1923-1924: Glasgow University Court minutes, 4 Oct. 1923 (C1/1/31, p. 14). This is the only reference found to Messac, for which I owe thanks to Moira Rankin, archivist, Univ. of Glasgow.

${ }^{7}$ Ralph Messac, "Le Detective Novel ': histoire d'une these," Quinzinzinzili: le bulletin messacquien, no. 3, été 2008, 16, and email 2011-2012 from Olivier Messac.

${ }^{8}$ McGill University Calendar 1924-1925, 121-122; Principal Sir Arthur Currie to Alexis Martin, Victoria, B.C., ca. 1924, Acting Principal C. F. Martin, General Correspondence, 1922-38, MUA, RG2, C47, file 483; W. Bovey to C.A. Magrath, 30 Nov. 1925, "McG 1922-1939," MUA, RG2, C47, file 478. Jewish enrolment was high but Jewish applicants would soon be subject to quotas or higher matriculation standards or both.

${ }^{9}$ Hermann Walter was Lecturer in Modern Languages, 1901-1902, Prof. of German, 1902-1936.

${ }^{10}$ Joseph L. Morin, (B.A. McGill 1880), Hon. D.D., 1942 was Lecturer in French 1893-1907, Assist. Prof., Modern Languages, 1893-1922.

${ }^{11}$ The internal McGill developments appear in the minutes of the Board of Governors, especially under the dates 3 Oct. 1921 (trouble between Walter and Morin, fear for McGill's reputation); 24 Oct. 1921 (suspension of Walter); 19 Dec. 1921 (reinstatement of Walter); 1 May 1922 (suspension of Walter, reinstatement of Morin but Morin to retire after next session); 10 Aug. 1922 (continued suspension of Walter); 27 Oct. 1922 (there will be a new court case, Walter suspension continued); 29 Jan. 1923 (Walter reinstated, Modern Languages to split into German and French, Walter to head German); 30 July 1923 (Morin resignation noted).

${ }^{12}$ There were no Italian or Spanish departments yet so in effect it was the French Department.

${ }^{13}$ The Principal occasionally assured parents that their children would not acquire Quebec French accents in McGill French courses, while Stephen Leacock attested in 1924, that in staffing the French Department, "we only take French people." Department of French-vacancies, ca1920-1930 (includes Leacock to "Wilfred" 26? June? 1924), MUA, RG 32, C 8, file 2253.

${ }^{14}$ Durand said the jury found in Messac: "la solidité et la précision de connaisance, une grande clarté d'exposition, et, dans la dissertation écrite sur un subject littéraire, un art de la composition et un réel talent de style qui lui ont valu le succès le plus mérité." Department of Modern Languages-French, 1922-1925, MUA, RG 2, C 61, file 1001.

${ }^{15}$ Department of Modern Languages-French, 1922-1925, MUA, RG 2, C 61, file 1001, general testimonials by René Durand (in French, 6 avril 1924), Prof. Fèlix Gaiffe (in French, 3 avril 1924), Charles A. Martin (1 June 1924).

${ }^{16}$ Algy Noad Fonds (mixed with Harold Files Fonds), MUA, MG1063, notes on Poe, n.d. 
${ }^{17}$ Course descriptions and instructors are given in the annual McGill University Calendar. French Dept. staff during Messac's time, 1924-1929, with overlaps, were: Professor and Chairman, René du Roure (1912-1914, 1922-1940); Associate Professor: Paul Villard (1915-1935); Assistant Professors: Régis Messac, Mrs. Lucie Touren Furness (1918-1953), Laurence A. Bisson (1926); Lecturers: Mlle. B. Framery 1924-25) Mme. Jeanne Durand-Joly (1928-1930), André Roche (1923-1926), L. d'Hauteserve (1926-1960, later years Professor), Mlle. Benoit (1926-7). This does not include part time or French Summer School staff. Female French instructors usually resided in Royal Victoria College if unmarried.

${ }^{18}$ Letters, du Roure to A.P. Glassco, Secretary, McGill University, 20 Sept.1926; du Roure to Dean MacKay, 13 Oct. 1926, French Department, 1920-1946, MUA, RG32, C19, file 126. Similar situation in Fall 1927: du Roure to MacKay, 4 Oct. 1927, MUA, RG32 C19 file 126.

${ }^{19}$ Report of Dean of McGill College (Ira MacKay), ca. 1929, Arts and Science, General, 1927-33, MUA, RG2, C58, file 902.

${ }^{20}$ Régis Messac, Le 'Detective Novel' et l'influence de la pensée scientifique, Paris 1929, republished with notes, Encrage, Paris 2011; Ralph Messac, "Le Detective Novel': histoire d'une these," Quinzinzinzili: le bulletin messacquien, no. 3, été 2008, 16.

${ }^{21}$ Le voyage de Néania, 1926, published anonymously, reviewed favorably in Le Progrès civique, no. 395, 5 mars 1927, 390. To be republished by Éditions ex nihilo, Paris.

${ }^{22}$ Régis Messac, "Bulwer-Lytton et Dostoievski-de Paul Clifford à Raskolnikov," Revue de literature comparée," no. 4, 1926, 638-653; "Déterminisme et histoire littéraire," la Science moderne, sept. 1926, 480483; "L'Homme artificial," la Science moderne, vol. iv, juin 1927, 281-284; "l'Homme invisible," la Science moderne, vol. v, 1928, 276-278; "Autour de Gavroche," Revue d'histoire littéraire de la France, xxxv, 1928, 577-589; "Le style du roman feuilleton," la Grande Revue (Paris), no. 12, déc. 1928, 221-234; "Fenimore Cooper et son influence en France," Publications of the Modern Language Association of America, vol.XLIII, no. 4, Dec. 1928,11991201; "Voyages modernes au centre de la terre," Revue de literature comparé, no. 9, jan. 1929, 74-104. Possibly written before arriving at McGill was "Cain et le probème du mal," Revue de literature comparé, vol. 4, oct.-déc. 1924, 620-652. His secondary thesis, Influences françaises dans l'auvre d'Edgar Poe, Librairie Picart, came out in 1929. These citations are from Robert Michel, Postface, Smith Conundrum, Éditions ex nihilo, Paris, 2011, 169 as well as additions received from Olivier Messac.

${ }^{23}$ E.A. Everts, Library, U.S.M.A., West Point, to Messac, 19 Aug. 1927; Harry Clemons, University of Virginia to Messac, 9 July 1928, 12 Oct. 1928 (in the latter, Clemons also congratulates Messac on having his thesis ready for the press). Photocopies kindly supplied of originals in possession of Olivier Messac, Fonds Régis Messac, Paris.

${ }^{24}$ Régis Messac to Thomas O. Mabbott, 30 Nov. 1928, Thomas O. Mabbott Papers, MsC 429, Special Collections \& University Archives, University of Iowa.

${ }^{25}$ P.D. James, Talking About Detective Fiction. Alfred A. Knopf, New York, Toronto 2009, 175.

${ }^{26}$ Astrid Llado, "Messac en Amérique" Régis Messac : un écrivain journaliste à re-connaitre, ed. Natacha Vas-Deyres and Olivier Messac, Éditions ex nihilo, Paris, 2011, Éditions ex nihilo, Paris, 2011, 101-114.

${ }^{27}$ Pierre-Gilles Pélissier, "Germes journalistiques de la fiction messacquienne," Régis Messac: un écrivain journaliste à re-connaitre, 115-128.

${ }^{28} \mathrm{His}$ articles in this Parisian journal were unlikely to have been read at McGill. In addition to academic articles on Determinisme and on Bulwer Lytton and Dostoyevski, he reported four of his articles in Le Progrès civique in the section of the McGill Annual Report for staff publications: they were on Anatole France, Herman Melville, "Une heure avec les fondementalistes," and "Homais à l'américaine," McGill University Annual Report, 1926-1927, 24. No publications by Messac were listed in Annual Reports for 1924-1925 and 1925-1926.The 1927-1928 and (abridged) 1928-1929 reports did not list staff publications.

${ }^{29}$ For example, letters criticizing Messac's "L'hygiène américaine," both signed "Un Français des Etats-Unis: Le Progrès civique, no. 392, 19 fév. 1927, 33; no. 400, 16 avril 1927, 32.
${ }^{30}$ Astrid Llado, "Messac en Amérique," Régis Messac: un écrivain journaliste à re-connaitre, 111.

${ }^{31}$ Régis Messac, "C'est entendu: les ouvriers américains ont leur auto... mais ils l'achètent à la petite semaine," Le Progrès civique, no. 325, 7 nov. 1925, 15-18.

${ }^{32}$ Régis Messac, "Les Chevaliers du Conformisme," Le Progrès civique, no. 330, 12 déc. 1925, 20-21. See Llado, "Messac en Amérique,"Régis Messac: un écrivain journaliste à re-connaître, 110.

${ }^{33}$ Régis Messac, "Le fruit defendu," Le Progrès civique, no. 343, 13 mars 1926, 20-21. Readers' reaction and Messac's reply were published in nos. 344, 31; 349, 31-33; 352, 30-31.

${ }^{34}$ Lettre, Messac, Montreal, 31 mars 1926, Le Progrès civique, no. 349, 24 avril 1926, 31-32.

${ }^{35} \mathrm{He}$ had read these regulations and perhaps also experienced them when landing in New York.

${ }^{36}$ Stephen Leacock, My Discovery of England, Dodd, Mead, New York 1922, 14.

${ }^{37}$ Régis Messac, "L'intelligence américaine et les problèmes de l'immigration," Le Progrès civique, no. 335, 16 janvier 1926, 86-87. The title conveys Messac's usual irony.

38"Mental Tests for Baylor Students", McGill Daily, 28 Oct. 1924, 1. Similarly, "Method Needed to Measure Intellect" appeared in the Daily, 14 Dec. 1928, 4.

${ }^{39}$ Régis Messac, “Jim Crow: le Noir et le Blanc," Le Progrès civique, no. 365, 14 août 1926, 17-19 ; Llado, "Messac en Amérique,"Régis Messac: un écrivain journaliste à re-connaître, 112.

${ }^{40}$ Régis Messac, "Une heure avec les fondamentalistes," Le Progrès civique, no. 381, 4 déc. 1926, 10-11.

${ }^{41}$ Régis Messac, "L'hygiène américaine, quand on la regarde d'un peu près," Le Progrès civique, no. 387, 15 jan. 1927, 8-10. Messac reponded to criticism from French people living in the U.S. in No. 405, 21 mai 1927, 36-37.

${ }^{42}$ Régis Messac, "Herman Melville," Le Progrès civique, no. 395, 12 mars 1927, 17-18; Le 'Detective Novel', (2011 edition), 465.

${ }^{43}$ Régis Messac, "Anatole France vu par les Américains," Le Progrès civique, no. 398, 2 avril 1927, 16-18.

${ }^{44}$ Régis Messac, "Les tabloids-Une formation nouvelle du journalisme aux Etats-Unis," Le Progrès civique, no. 415, 30 juillet 1927, 16-18.

${ }^{45}$ Régis Messac, "La femme isolée aux Etats-Unis," Le Progrès civique, no. 419, 27 août 1927, 18-20. Regarding frivolous topics, Messac may have been thinking of a talk at the McGill women's Société Française on the fashion of short hair for women, which concluded that women were conquering all "by short hair and short skirts," McGill Daily, 4 Nov. 1926, 1; 5 Nov. 1926, 1.

${ }^{46}$ Régis Messac, "La foi, la fausseté et la faillite de la 'Christian Science," Le Progrès civique, no. 434, 10 déc. 1927, 20-22, discussing W. Riley, F.W. Peabody and C. Humiston, The Faith, the Falsity and the Failure of Christian Science, 1925. Objection soon came from Caroline Getty, Christian Science Committee on Publication for France: no. 436, 37.

${ }^{47}$ Régis Messac, "Homais à l'américaine," Le Progrès civique, no. 361, 17 juillet 1926, 14-16.

${ }^{48}$ Régis Messac,"Les plumatifs et le veau d'or," Le Progrès civique, no. 454, 28 avril 1928, 18-19.

${ }^{49}$ Régis Messac, "Ne nous extasions pas sur le sport américaine! Connaisons-pour les éviter - ses tares profondes," Le Progrès civique, no. 469, 11 août 1928, 14-16.

${ }^{50}$ Régis Messac, “Une revolution, qu'est-ce que c'est?” Le Progrès civique, no. 467, 28 juillet 1928, 23-24.

${ }^{51}$ Régis Messac, "La guerre du Pacifique," Le Progrès civique, no. 487, 15 déc. 1928, 8-10. A reaction, that war between America and Japan was unlikely, was published in no. 492, 19 jan. 1929, 30.

${ }^{52}$ According to Lovell's Montreal Directory, the Messacs lived at Apartment 8, 2024 St-Denis, now a hotel (Lovell's 1925-26, 1154); 2045 Blvd StJoseph Est on $2^{\text {nd }}$ or $3^{\text {rd }}$ level (Lovell's 1927-28, $108 \& 1215$ ); and 6525 Ave. Molson (Lovell's 1928-29, 352 \& 1284). 
${ }^{53}$ Régis Messac, Réflexions sur les voyages," Les Primaires, avril 1932, $283-$ 287.

${ }^{54}$ The book was Neuvaine à saint Pierre Claver, Montreal 1923, 81 pages. Claver, patron saint of slaves, ministered to African slaves in New Spain (Grenada) and died of Parkinson's disease in 1684.

${ }^{55}$ Régis Messac, "Histoires Canadiennes," L'Idée Libre, 12 ème Série, no. 6, juin 1935, 242-245. They spoke in French of course. At this time, ca. 1925 to 1927 , the Messacs lived at 2045 Blvd. Saint-Joseph Est, a residential French-speaking neighbourhood close to downtown Montreal, opposite the church. This and several other articles by Messac in the 1930s were kindly selected and sent by Olivier Messac.

${ }^{56}$ Email, Olivier Messac to Robert Michel, 12 July 2012.

${ }^{57}$ Old McGill, 1924, 36.

${ }^{58}$ The Société Française narrowly lost to the Cercle, defending the resolution that man not woman constitutes the weaker sex: McGill Daily, 4 Nov. 1924, 3; 18 Nov. 1924, 1.

${ }^{59}$ The Daily seldom used French accents. Roche humorously complained about this in its coverage of the Cercle, McGill Daily, 30 Nov. 1925, 2. The Daily's spoof issue, The Mongrel Daily (April Fool's Day, 1925), 40, retorted with deliberate lack of accents: "There will be a meeting of the Societe Francais, the Societe Francaise and the Societe Francaise [sic] in the Music Room to-night. The speaker will not be present as he was forced to roche away for some inexplicable reason."

${ }^{60}$ McGill Daily, 16 Oct 1924, 3.

${ }^{61}$ In Montreal Standard, 5 Feb. 1921. Leacock bibliographies: Ralph Curry, "Stephen Leacock: the writer and his writings" (bibliography), Leacock: a Reappraisal, ed. David Staines, University of Ottawa Press, Ottawa, 1986, 143; Carl Spadoni, A Bibliography of Stephen Leacock, ECW Press, Toronto 1998.

${ }^{62}$ McGill Daily, 18 Oct. 1924, 1; 28 Oct. 1924, 1. The Daily gave fairly detailed summaries of Cercle debates. Group portraits of the student executives and staff advisors of the Cercle Français (of du Roure and Villard, not Messac or Roche) and Société Française are found in the Old McGills. So far as images go, Messac was an invisible man at McGill. He is found in no photographs in McGill's collections nor in the indexes to the Notman Photographic Collection at McCord Museum.

${ }^{63}$ For example, McGill Daily Literary Supplement, vol. I, no. 4, 29 Oct. 1924, 2.

${ }^{64}$ McGill Daily, Railways: 22 Nov. 1924, 1; 24 Nov. 1924, 1,3; 25 Nov. 1924, 1,3; Pen vs. Sword: 1 Dec., 1924, 1; 6 Dec. 1924, 1, 3; 8 Dec. 1924, 1; 9 Dec. 1924, 1 (latter story in French, a rare occurance).

${ }^{65}$ McGill Fortnightly Review, vol. 1, no. 6, 6 Feb. 1926, 47-48.

${ }^{66}$ McGill Daily, 23 Feb. 1925, 4; 24 Feb. 1924, 1.

67 “Cercle held Initial Meeting Last Evening," McGill Daily, 20 Oct. 1925, 1.

68"Second Séance of the Cercle Francais Held," McGill Daily, 1,2. Does not specify who told which anecdote.

${ }^{69}$ McGill Daily, 23 Nov. 1925, 1.

${ }^{70}$ McGill Daily, 24 Nov. 1925, 1.

${ }^{71}$ McGill Daily, 25 Nov. 1925, 2; 26 Nov. 1925, 2.

${ }^{72}$ McGill Daily, 18 Nov. 1926, 1.

${ }^{73} \mathrm{McC}$ ullagh attended some meetings of the Cercle, for example, the meeting of 22 Jan. 1929: McGill Daily, 23 Jan. 1929, 1. Perhaps he and Messac were well acquainted. A less likely candidate from Classics is Carleton Stanley.

${ }^{74}$ Editorial, unsigned, McGill Fortnightly Review, vol. 2, no. 7, 10 Mar. 1927, 1. The Fortnightly mocked McGill's subservience to businessmen and criticized many aspects of university life.

${ }^{75}$ Letter to the Editor by Abby Litovsky (B.A. 1926), McGill Daily, 20 Nov. 1926,4 , decries "the entrance into our college life of a highly developed form of professional sport... it will soon come to this that prize-fighters and weight-lifters will soon have more say in our college life than principals and professors."

${ }^{76}$ McGill Daily, 24 Feb. 1928, 1.
${ }^{77}$ Robert Michel, "The Gates of McGill: an unpublished novel of the 1920s by 'Dink' Carroll," Fontanus, XI, 2003, 12-60; Michel, "Fiction, Faction, Autobiography: Norman Levine at McGill University, 1946-1949," Fontanus, XII, 2010, 63-104. The genre was already long established in England with Edward Bradley's Verdant Green (1857), Thomas Hughes's Tom Brown at Oxford (1861) and Max Beerbohm's fantasy Zuleika Dobson (1911).

${ }^{78}$ The chapters were unnumbered; most were first published serially in Le Progrès civique, beginning in no. 475, 22 Sept. 1928 to no. 625, 20 Sept. 1931 in the following order: La fille de Peudzippah, no. 475, 22 sept. 1928; Film interdit par la Censure, no. 522, 17 août 1929; Jamais content, no. 534, 9 nov. 1929; Le Rah-Rah-Boy, no. 570, 19 juillet 1930; Honoris Causa, no. 575, 23 août 1930; La bataille de Tipperary, first part, no. 578, 13 sept. 1930 and second part, no. 579, 20 sept. 1930; L'Academicien I, no. 620, 4 juillet 1931; L'Académicien II, no. 621, 11 juillet 1931; L'Académicien III, no. 622, 18 juillet 1931; L'Académicien IV, no. 623, 25 juillet 1931; L’Académicien V, first part, no. 624, 1 août 1931 and second part, no. 625, 8 août 1931. Le Professor Talkinghorse et l'idée de genie was published under the pseudonym Laurent Zurbarran in le Quotidien, no. 4062, 31 mars 1934. There is no known pre-publication of the chapters Graeculus esuriens, Les livres and On rentre. Regarding the title, O. Messac suggests that Régis chose "Smith" as the most common Anglo-Saxon surname and "Conundrum" as suggestive that founder Smith's social ascent was an enigma.

${ }^{79}$ Régis Messac, Smith Conundrum: roman d'une université américaine. The novel was announced in the list of la Fenêtre ouverte in 1935 but did not appear. Finally it was published as a complete book (with chapters in slightly different order than that in which the serial versions appeared) by L'Amitié par le Livre, Querqueville (Manche), vi \& 169 pp., 28 francs) in 1942. The dates of writing Messac gave in the 1942 edition, of octobre 1930-février 1931, are too condensed. The 1942 edition is very rare as most copies were forbidden and possibly destroyed by the German occupiers, others accidently destroyed by the advancing Americans. Smith Conundrum was republished by Éditions ex nihilo, Paris, 190 pp., 2010 with a preface by Marc Angenot and an afterword by Robert Michel (afterword translated from English into French by Jean-Marie Jot). The 1942 edition published L'Académicien as one chapter with 5 parts. The 2010 edition published L'Académicien as 5 separated chapters and Graeculus esuriens as two separated chapters modifying its 1942 division into 2 parts in one chapter. The 1942 and 2010 texts appear to be identical and the 2010 edition has 7 explanatory footnotes. With a colorful new cover by Quebec illustrator Cozic, the book is available from Éditions ex nihilo, 42 bis rue Poliveau, Paris V.

${ }^{80}$ Marc Angenot's note about his discovery of Smith Conundrum appeared in the McGill Reporter, 23 April 1975, with a translation of the chapter Honoris Causa by Gladys Quirk. At that time, I photocopied Angenot's photocopy (from BnF) of the 1942 edition for the McGill University Archives where I was an archivist. See also Angenot, "Smith Conundrum: un roman satirique sur McGill University," Voix et images, vol. 3, no. 1, 1977, 162-165 and Angenot, Préface, Smith Conundrum (Éditions ex nihilo, Paris, 2010). A small file on the discovery was assembled by the McGill Information Office, 1975, MUA, RG49, C101.

${ }^{81}$ Marc Angenot, preface to Smith Conundrum, 2010 edition, 12-13.

${ }^{82}$ L'Académicien, [V part 2], Le Progrès civique, no. 625, 8 août 1931, 14.

${ }^{83}$ Three weeks after its ratification, the Kellogg Pact was mentioned in the first published chapter: "La fille de Peuzippah," Le Progrès civique, no. 475, 22 September 1928.

${ }^{84}$ Except for the chapter Honoris Causa translated by Gladys Quirk, Mc Gill Reporter, 23 April 1975.

${ }^{85}$ As well, Pluche's name suggests peluche, the plush of teddy bears. A student in the novel refers to Pluche having a bearish reputation. Most likely, as Olivier Messac suggests, Pluche derives from Abbé Pluche (1688-1761). “André J." probably comes from Messac's colleague André J. Roche; and indeed, "Pluche" shares the sound of "Roche." Most fancifully, an André M.H. Pluche (1887-1915), sergent-fourrier au 67 ème RI was killed, MPLF, 21/6/1915; could Messac have given him a new life? Pluche calls himself "l'ex-quartier maitre" in Jamais content.

${ }^{86}$ Canadian immigration officers described Messac as five feet six inches tall $(=167.6 \mathrm{~cm})$, with brown eyes and brown hair. 
${ }^{87}$ Sinclair Lewis, Babbitt, 1922, chapter III, pt. iii; chapter V, pt. ii. Messac also used the term "California Building" in his tirade against the "Bunk" of American civilization: “Bunk; ou Plein la vue!” Le Progrès civique, no. 352, 15 mai 1926, 16 .

88"Roddick Gates nearing completion," McGill Daily, 9 Dec 1924, 2; "Roddick Gates are now closed to traffic. Cost \$50,000." McGill Daily, 5 Jan. 1925, 1. Messac, like his students, probably read the Daily.

${ }^{89}$ Ira MacKay, Dean of Arts to Principal Currie, 21 April 1926; Currie to MacKay, 22 April 1926, Arts and Science-General, 1919-1926, MUA, RG2, C58, file 903.

${ }^{90} \mathrm{My}$ count from the McGill Calendar, 1927-1928. There were other appointments, mainly demonstrators in medicine and science, totalling another 197.

${ }^{91}$ Messac, Le 'Detective Novel,' (2011 edition, 540 n.1).

${ }^{92}$ For example, no letter or reference to Messac appears in The Letters of Stephen Leacock, ed. David Staines with Barbara Nimmo, Oxford University Press, Don Mills, Ontario, 2006 (564 pp.) or in other writings on Leacock.

93 "Bunk" was in vogue; just after Messac's "Bunk," Leacock titled an article "Old Junk and new Bunk," Collier's 78, 30 Oct. 1926, 20: Ralph R. Curry, "Stephen Leacock: the Writer and his Writings," Leacock: a Reappraisal, ed. Staines, 20 .

${ }^{94}$ Stephen Leacock, "Rah! Rah! College," Afternoons in Utopia, Macmillan of Canada, Toronto, 1932, 120,125.

${ }^{95}$ Leacock, My Discovery of England, 115. The chapter "Oxford as I See It" contains perhaps Leacock's fullest, brightest critique of North American universities. While not against women's education (102-109), Leacock argued against coeducation, claiming that women did better in women's colleges: "They are freer, less restrained. They discuss things openly in their classes; they lift up their voices, and they speak, whereas a girl in such a place as McGill, with men all about her, sits for four years as silent as a frog full of shot": 106. Perhaps Pluche's talkative Goldeye Belemnith was reacting against this timid stereotype! Leacock thought most women would marry, making their university learning superfluous and soon forgotten. In My Discovery, 14, Leacock also tells British officials he is an "anarchistic polygamist."

${ }^{96}$ See Ian Ross Robertson, "The Historical Leacock," Leacock: a Reappraisal, ed. Staines, 47-48.

${ }^{97}$ The headings here are the Smith Conundrum chapter titles. As the texts of 1942 and 2010 are the same and the chapters are short, page citations are not given.

${ }^{98}$ Waugh was Kingsford Chair of History, 1925-31, author of James Wolfe, man and soldier, Montreal, L. Carrier, 1928.

${ }^{99}$ Report by Principal A.W. Currie, McGill University Annual Report 1924-1925, 35-38.

${ }^{100}$ French Department, 1920-1946, MUA, RG2, C47, file 483.

${ }^{101}$ According to J. Harkness, Acting Dean of Arts, 1921 in c.v. of Villard, probably compiled for the Dean: French department, 1920-1946, MUA, RG32, C19, file 126.

${ }^{102}$ In 1927-1928 McGill had 8 students from China and 3 from Japan according to Old McGill, 1929, 21.

${ }^{103}$ Messac continued inventing funny names, such as Tenterhook, Compost and Foothold, in another novel focusing on his American targets: religion, the Ku Klux Klan and maltreatment of Blacks: Le miroir flexible, 1933, republished by Éditions ex nihilo, Paris, 2008.

${ }^{104}$ Thomas O. Mabbott Papers, MxC 429, Special Collections \& University Archives, University of Iowa; C.K. Ogden Fonds, William Ready Division of Archives and Research Collections, McMaster University; and David H. Keller Collection, McCabe Library, Swarthmore College.

${ }^{105}$ DuBoyce as the inspiration for "des Boys" was suggested by Olivier Messac.

${ }^{106}$ Listed as René des Roys du Roure in Lovell's Montreal Directory, 1926-27 (Apt. A, 70 Cedar Ave.).

${ }^{107}$ On Chicago influences at McGill in sociology and social work, see Marlene Shore, The Science of Social Redemption: McGill, the Chicago School, and the Origins of Social Research in Canada, University of Toronto Press, Toronto, 1987, and on Caldwell, 32-36, 51.

${ }^{108}$ A description of Columbia's French and other summer sessions is given by Paul Hazard, "Six professeurs Français à l'Université Columbia," Revue des Deux Mondes, oct. 1923, 622-634.

${ }^{109}$ Juvenal, Satires, iii.76. Translations vary: "Command the little Greek to ascend to heaven and he will try to do it." I am indebted to Olivier Messac's remarks regarding Messac's meaning.

${ }^{110}$ Régis Messac, A Bas le Latin! 1933, republished, ed. Olivier Messac with preface by Anne-Marie Ozanam, Éditions ex nihilo, Paris, 2010.

${ }^{111}$ Except with beginners, all French departmental teaching was supposedly done in French. Smith Conundrum indicates lapses into English occurred; in Jamais content, for example, des Boys says that we demand the students speak French, at least in the higher level classes.

${ }^{112}$ Leon Edel, “The Young Warrier in the Twenties," On F.R. Scott, ed. Sandra Djwa and R. St J. Macdonald, McGill-Queen's, Kingston and Montreal 1983, 10-11. Messac may have been well aware of literary efforts at McGill. Felix Walter, B.A. 1923, M.A. 1924, the son of Messac's friend Hermann Walter, wrote for the McGill Daily, ca. 1923-1924 and earned his doctorate in comparative literature under Messac's director F. Baldensperger from the Sorbonne in 1927. Leon Edel called Felix the "founding grandfather" of McGill's literary movement: ibid., 9. Perhaps Messac knew Felix.

${ }^{113}$ See Brian Trehearne, Aestheticism and the Canadian Modernists: Aspects of a Poetic Influence, McGill-Queen's, Kingston, Montreal, London 1989, 230-235. Messac may have enjoyed F.R. Scott's spoof of Pittsburgh's skyscraper university, with futuristic automation and a different degree offered on each of its 52 floors: Scott, "The Cathedral of Learning," McGill Daily Literary Supplement, 19 Nov. 1924, 1,4. See Comment elsewhere in this volume: Robert Michel, "Frank Scott's University of Dystopia, 1924."

${ }^{114}$ A shelf read of theses, 1925-1930, in McGill's McLennan Library, turned up the following M.A. theses presumably written for the French Department-supervisors were not specified: Alice Sharples, "Le théâtre en liberté de Victor Hugo," 1925; Edith Creighton, "La legend Napoléonienne dans l'oeuvre de Béranger," 1926; and Drucilla Stager, "Jeanne d'Arc dans le theatre modern anglais et français," 1926.

${ }^{115}$ The fullest account is Don Bell, The Man Who Killed Houdini, Véhicule Press, Montreal 2004, 68 and passim.

${ }^{116}$ Messac's use of "Syd" may come not only from "Cid" but from Syd Chaplin (Charlie's half-brother), who played in The Man on the Box (Warner Brothers, 1925), reviewed unfavorably in the McGill Daily, 26 Nov. 1925, 2. Another Messacquian extrapolation might have been C. Chaplin's film "The Kid" [Cid?] 1921!

${ }^{117}$ Régis Messac, "Bunk; ou Plein la vue! Le Progrès civique, no. 352, 15 mai 1926, 18. From minus habens - intellectually deficient.

${ }^{118}$ McGill Daily, 24 Nov. 1928, 1, 4. M. Joub, who played Rodrigue, complimented the McGill audience on its quick understanding compared to other Montreal audiences. This was stated to be the first performance of El Cid in Montreal. In November 1926, a recitation from El Cid had been given in Montreal: McGill Daily, 5 Nov. 1926, 1.

${ }^{119}$ Ralph L. Curry, Stephen Leacock: Humanist and Humorist, Doubleday \& Co., New York, 1959, 187.

${ }^{120}$ Brigitte Olivier-Cyssau, René du Roure, privately printed, ca.2008 covers $\mathrm{du}$ Roure's family life as well as his career. Du Roure was preceded in the French Department (1895-1900) by another dramatic Frenchman, Maxime Ingres.

${ }^{121}$ The $3^{\text {rd }}$ floor of McGill's Arts Building still has small offices including one numbered 345 .

${ }^{122}$ Principal A.W. Currie to Consul General of France, Montreal, 6 Mar. 1922, Dept. of Modern Languages-French, 1922-1925, MUA, RG2, C61, file 1001. Du Roure asserted French was better taught in the primary schools of Montreal than in the rest of North America: R. du Roure to Members, Protestant Board of School Commissioners, ca. 1931-1932, MUA, RG32, C53, file 2000; R. du Roure to Vice-Principal Charles Martin, 21 Mar. 1929, "Dept. of Romance Languages, French, 1922-1933," MUA, RG2, C61, file 995. 
${ }^{123}$ René du Roure, "L’Appel de la Race," La Revue Moderne, vol. iv, no. 2, déc. 1922, 8-9. While the novel was signed "Alonié de Lestres", Du Roure emphasized that it was no secret that the author was "un historien canadien d'une certaine reputation." Du Roure published other articles in the same journal, including "La literature et les Loisirs," Ge année, no. 9, juillet 1925, 6-7.

${ }^{124} \mathrm{R}$. du Roure wrote to Dean of Arts Ira MacKay, 17 June 1926 requesting him and Principal Currie to approve Messac's returning late in Fall 1926 from researching in France; du Roure would teach his courses: "French Department 1920-1946," MUA, RG32, C19, file 126. Du Roure had to cover for over a month as immigration records show that the Messac family returned to Quebec on the the S.S. Alaunia (Cunard) on 31 October 1926: LAC, Immigration Records, 1925-1935, 1926,vol 23, p.5, microfilm reel $\mathrm{T}-14729$.

${ }^{125}$ Courtesy of Marc Angenot, the present owner.

${ }^{126}$ Clifton L. Hall (M.A., McGill 1932), "Men Who Taught Me," Peabody Journal of Education, vol. 46, no. 3, Nov 1968, 131-135; cited by Brigitte Olivier-Cyssau, René du Roure, 2008, unpaginated.

127 “Professor René du Roure dies suddenly," McGill News, Winter 1940, vol. 22, no. 2,54 .

${ }^{128}$ The works not cited in my text are Jacob Bohm, L'aurore naissante ou la racine de la philosophie (an edition was published in Milan, 1927); Stéfan Christesco, l'Éthéronique et les archives de l'univers, Paris 1928; Wolfgang Kéohler, l'Intelligence des singes supérieurs, Paris 1927; Ch. Picard, "Phèdre à la balançoire et le symbolisme des pendaisons," Revue Archéologique, $5^{\text {th }}$ ser. 28 (1928), 47-64. An internet search failed to verify one title: Bernadotte Wilhalmhjur, "Les orages dans la littérature finnoise." McGill's Library holds Hoxie Fairchild, The noble savage: a study in romantic naturalism, Columbia University Press, New York 1928, Accession no. 241209, date 1929- perhaps Messac like Pluche requested it.

${ }^{129}$ In the preface to Le 'Detective Novel,' Messac thanked "le Dr Lomer et tout le personnel de la 'Redpath Library' qui mont considérablement aidé à réunir ma documentation....”

${ }^{130}$ Fernand Baldensperger, Études d'histoire littéraire (1907), borrowed in April 1928, before Messac would have seen him that summer. The McGill French professors may have recommended books to each other: A.J. Roche and Messac borrowed Pierre MacOrlan, La cavalière Elsa (1922) on 15 May 1926 and 7 July 1926 respectively, the next borrower was Touren Furness in Feb. 1928.

${ }^{131}$ Borrowed between 5 May 1926 and 9 Oct. 1928, these 17 cards and books bear accession numbers between 213,425 and 235,681, which correlate with the run of numbers assigned to new books at that time.

${ }^{132}$ Assistant Bursar, McGill, to Messac, 5 Dec. 1927. Supplied by Olivier Messac from the Fonds Régis Messac, Paris.

${ }^{133}$ Régis Messac to Thomas O. Mabbott, 30 Nov. 1928, Thomas O. Mabbott Papers, MsC 429, Special Collections \& University Archives, University of Iowa.

${ }^{134}$ Régis Messac, Le 'Detective Novel' et l'influence de la pensée scientifique, Paris 1929, McGill Libraries, Rare Book Division, PN3448 D4 M47 1929. Lomer gave the Library his copy.

${ }^{135}$ Old Mc Gill, 1927, 151.

${ }^{136}$ Slightly simplified from Le Rah-Rab-Boy in Smith Conundrum. Messac has the students yell "C-O-N-N and "conn" perhaps adding a second "n" to avoid writing the derogatory French slang "con" for which a polite translation is "idiot." "Conundrum" and "conn" also suggest "connerie."

${ }^{137}$ The yell appears in the The McGill Song Book, published by the McGill Students' Council (1921) and other student publications, e.g., McGill Student Handbook, 1926-1927, 17; McGill Daily, 1 Oct. 1925, 4; 2 Oct. $1925,3$.

${ }^{138}$ The host Canadian Prime Minister Mackenzie King was not snubbed; he already had received an honorary degree from McGill in 1929.

${ }^{139}$ Woodhead, his humour, pipe smoking, and humorous verses about fellow staff are described by T.H. Matthews, "Woodie," McGill News, vol. 36, no. 3, Summer 1955, 18-19 and T.W.L. MacDermot, "William Woodhead: an Appreciation," McGill News, vol. 38, no. 4, Autumn 1957, $21,34$.
140"Imposing scenes at Conferring of McGill Degrees," Montreal Daily Star, 9 Apr. 1926. Honnorat towers over du Roure in the photograph, same source, 10 Apr. 1926. This and other news clippings on the Convocation are in MUA, RG7, McGill University Scrapbooks, vol. 6, 121-130. The speeches, list of those invited, and program of events are in the Minute Book of Convocation, 1909-1927, 518-521, MUA, RG7, C413, file 375. Coverage is also in McGill Daily, 21 Apr. 1926, 1. Related correspondence with Atholl, Honnorat, Baron de Vitrolles, et al.: "Honorary Degrees, 1924-1928," MUA, RG7, C52, file 961. An honorary degree was planned about the same time for Sir Alexander F. Whyte, who eventually was scheduled to receive his at the regular Convocation on 29 May 1926.

${ }^{141}$ In 1926 Ruttan was in conflict with the Dean of Arts over aspects of the Chemistry program: Dean Ira MacKay to Principal Currie, 15 Oct. 1926, MUA, RG2, C58, file 903. Old McGill 1929 was dedicated to Ruttan, retiring after 40 years (with colour photograph, 4-5).

${ }^{142}$ W.D. Woodhead, “The Professors, God Bless 'Em," McGill News, vol. 31, no. 4, Summer 1950, 18.

${ }^{143}$ Minute Book of Convocation, 1909-1927, 520, MUA, RG7, C413, file 375 .

${ }^{144}$ Gladys Quirk, "Honoris Causa, from the twenties, a Convocation lampoon," McGill Reporter, 23 April 1975, 5.

${ }^{145}$ Reported in the Montreal Gazette, and Montreal Daily Star, 3 May 1926.

${ }^{146}$ Paul Fussell updated this charge in Class, Ballantyne Books, New York, 1984, chapter 6 .

${ }^{147}$ S. Leacock, "A Convenient Calendar for Future Years," Old McGill 1931, 62. Decrying legislative or benefactors' attempts to control what was taught at universities, Leacock suggested that benefactors should merely say: "Here is a million dollars," and universities reply "Yes- here is an LL.D." From "Leacock Describes Colleges of Past and Present," Montreal Gazette, 24 Feb. 1926.

${ }^{148}$ Régis Messac, "Bunk; ou Plein la vue!” Le Progrès civique, no. 352, 15 mai 1926, 15-18.

${ }^{149}$ Information on the McGill French Summer School comes from the published calendars French Summer School, McGill University for the years 1925, 1926 and 1927 (the years Messac taught). The calendars gave courses with instructors' names and information on registration, examinations and activities. Copies are in files on the French Summer School in MUA, RG7, C39, file 269; MUA, RG7, C382; MUA, RG32, C10, file 127. Correspondence is in Dept. of Romance Languages-French Summer School, 1923-1926, MUA, RG2, C61, file 996; French Summer School, MUA, RG32, C10, file 127. Some School events were noted in the University Scrapbook of newsclippings, vol. 6, covering the mid and late 1920s, and in the McGill News.

${ }^{150}$ L'Académicien [I], Le Progrès civique, no. 620, 4 juillet 1931, 15.

${ }^{151}$ Messac and McGill were "Chicago-aware." Besides Leacock, Gordon Laing, former Dean of Arts 1921-1923 and head of Classics had come from University of Chicago and W.D. Woodhead, chair of Classics, had a Ph.D. from Chicago (McCullagh would obtain his Ph.D. there but later). Since its founding in 1890, Chicago had emphasized graduate research and was a powerhouse of social science research, influencing McGill initiatives (involving Leacock among others) in sociology and social work in the 1920s and 1930s: see Marlene Shore, The Science of Social Redemption.

${ }^{152}$ Marie Le Franc published a story with a French department head resembling du Roure and glimpses of what may have been the French Summer School's extra activities: women from Omaha and Charlottetown visiting the art museum and debates on such subjects as whether it is possible for married men to continue to love their wives: Visages de Montréal, Montreal 1934, 120-125.

${ }^{153}$ McGill University, French Summer School, Annual Report 1926. Reports on the School also appear in the regular published McGill Annual Reports and the minutes of the Board of Governors.

${ }^{154}$ William Weintraub, City Unique, Toronto 1996, 116-117, 119-120, 246-247. It was famous for performances by Lily St. Cyr in the 1940s.

${ }^{155}$ Alice Sharples Baldwin, "Du Roure's soul was French, his blood blue," The McGill You Knew, ed. E.A. Collard, Longman Canada, Don Mills, Ont., $1975,75-77$. 
${ }^{156}$ The press noted this production and a ballet solo dance by Miss L. McNea: "Students in Plays at the French School," Montreal Herald, 29 July 1927, MUA, RG7, Scrapbook of newsclippings, vol. 6, 275.

${ }^{157}$ Brigitte Olivier-Cyssau, René du Roure, 2008, unpaginated.

${ }^{158}$ Lucie Touren Furness, Je me souviens, multilith memoir, 1973, MUA, MG4015 (Acc. 83-044); in 1927 Du Roure and the Dean of Arts supported Touren Furness's continued teaching and a small increase of salary to bring hers up to that of male staff : R. du Roure to Dean Ira MacKay, 1 Oct. 1927, "French Department, 1920-1946," MUA, RG32, C19, file 126; du Roure to Principal Currie, 1 Oct. 1927, Dean Ira MacKay to Principal Currie, 8 Oct. 1927, both in "Department of Romance Languages - French, 1922-1933," MUA, RG2, C61, file 995. She remained on staff full time, according to the Calendars.

${ }^{159}$ Relevant correspondence is in Department of Modern Languages-French, 1921-1925, MUA, RG2, C61, file 1000; Principal Currie to L.A. Bisson, 23 Mar. 1926, Currie to Col. Alexander Macphail, 3 Apr. 1926, Department of Romance Languages-French, 1922-1933, MUA, RG2, C61, file 995; Principal Currie to Dean of Arts MacKay, 22 Apr. 1926, Arts and Science-General, 1916-1926, MUA, RG2, C58, file 903.

160"Prefers to Teach McGill Students", McGill Daily, 13 Oct. 1926, 1.

${ }^{161}$ L.A. Bisson, Arcachon, Gironde, France, to Principal Currie, 17 July 1926, annotated by Currie granting the request to report late; and A.P. Glassco to du Roure, 17 Sept. 1926, R. du Roure, 1922-1936, MUA, RG32, C53, file 1998. The date and location Bisson wrote from are further evidence he did not teach at the 1926 French Summer School session.

${ }^{162}$ R. du Roure to Dean Ira MacKay, 17 Nov. 1926, French Department,1920-1946, MUA, RG32, C19, file 126.

${ }^{163}$ Minute book, Board of Governors, Finance Committee, 1919-1931, 17 Feb. 1927, 542, MUA, RG4, C20, file 9026. Bisson had been appointed 6 May 1926, same source, 514. The Calendar for 1926-1927 did not indicate which courses Bisson taught; he may have been hired too late for inclusion. While no professor's name was assigned to the medieval literature course (p. 188), presumably Bisson taught it.

${ }^{164}$ Bisson wrote several books in the 1940 s, including A short history of French literature from the middle ages to the present day (Penguin, 1943, 1945). Earlier he published a thesis for Université de Bordeaux in 1932 on Le romantisme littéraire au Canada français, a topic he appears to have begun at the Sorbonne. D'Hauteserve would teach at McGill from 1926 to 1960.

${ }^{165}$ Correspondence on Sonet (who was not on staff) including du Roure's letter, 28 June 1928, is in "Department of Romance Languages, 1927-1933," MUA, RG2, C61, file 993.

166"Balderdash," meaning "nonsense," was a popular expression. For example, the Old McGill 1928, 38, biography of Guy F. Simpson, B.A. 1928, noted his favorite expression was "sentimental balderdash." Simpson was a member of the Cercle Français; Messac may have heard it first from him! Since "balderdash" in French means "connerie," Olivier Messac suggests a double analogy-between "connerie" and "Currie" and also between "connerie" and "la grande Cônerie," the name for "l'Université" in Messac's La Cité des asphyxiés (1937).

${ }^{167}$ Tommy Matthews (B.A., M.A. Oxford), longtime Registrar, began at McGill teaching math. The real McGill Arts Building also had a common room.

${ }^{168}$ In the preface to Le 'Detective Novel', Messac thanked Walter "qui a gracieusement mis à ma disposition sa bibliothèque privée...."

${ }^{169}$ Messac noted of Walter's biography of the Jewish poet: "j'ai eu plaisir à voir comment vous aviez su vous dégager complètement du préjugé racial." The letter, Messac to Walter, 2 Feb. 1931, is in a scrapbook in the Hermann Walter Fonds, MUA, MG2014.

${ }^{170}$ Stephen Leacock, Arcadian Adventures Among the Idle Rich, John Lane, New York, 1914, 81.

${ }^{171}$ Winegar also wrote Problem in Bacteriology Clothing Study, Kansas State University, 1927, 28pp. Her research was reported on in The Literary Digest, 6 Oct. 1928, 23, in which she is affiliated to University of Nebraska. Winegar was a recognized expert on textiles and sanitation and gave public lectures. Euthenics is defined as "the science of improving human beings through control of environmental factors:" Funk $\mathcal{E}$ Wagnalls Standard Dictionary, New American Library, pb, no date.

${ }^{172}$ The students were always quoting Leacock's bon mots; however, Cadwallader Talkinghorse's research does not resemble Leacock's and Messac appears aimiably disposed to Leacock. Prof. William Caldwell, who may have lent his name and fame to Cadwallader T. was a "character," often mentioned in the Daily and Montreal press, receiving the Order of the White Lion Czechoslavakia (Montreal Gazette, 31 Jan. 1927), Order of Polonia Restituta (Montreal Daily Star, 21 Nov. 1927) and the like. He was made "officier d'Académie" for bringing understanding of French culture to the English speaking world: Montreal Gazette, 8 May 1929.

${ }^{173}$ Messac may be anticipating the start of the American Great Depression in late 1929 just after he left.

${ }^{174} \mathrm{Du}$ Roure forcefully requested - successfully - that Currie recommend to the Governors' Finance Committee modest salary increases to Professors D'Hauteserve, Furness, and Villard. He had asked for these (presumably including Messac) the previous year through regular channels without success: du Roure to Principal Currie, 10 Oct. 1929; Currie to du Roure, 10 Oct. 1929, Department of Romance Languages - French, 1922-1933, MUA, RG2, C61, file 995.

${ }^{175}$ Presumably Pluche meant he would leave at the end of the academic year the following June. No letter of resignation from Messac survives.

${ }^{176}$ Letter, Michel Poirier to Messac, 14 May 1928, Fonds Régis Messac, Paris; copy supplied by Olivier Messac. Glasgow University Calendar, 1923-1924, 26, lists Poirier as a temporary Assistant in French. He may have been there at the same time as Messac or earlier. Messac's name does not appear in the Calendar. My copy of Le 'Dectective Novel' (1929) is inscribed: "A mon excellent ami Michel Poirier cordial homage Régis Messac" (purchased from Kitazawa Bookstore, Tokyo, Dec. 2003).

177"The Acting-Principal submitted to the meeting the resignation of Professor Regis Messac to take effect at the end of this session. The meeting referred this to the Board of Governors with a recommendation that it be accepted:" Minute Book of the McGill Board of Governors Finance Committee, 1919-1931, 24 Jan. 1929, 606, MUA, RG 4, C 20, file 9026. The date of Messac's resignation is noted in courier des lecteurs, lettre de Robert Michel, Quinzinzinzili, no. 15, automne 2011. Ralph Messac had assumed the child's death was the immediate cause of the Messacs'return to France: "Le Detective Novel ': histoire d'une these," [reprinted in] Quinzinzinzili: le bulletin messacquien, no. 3, été 2008, 16. According to Ralph Messac, baby Francis had been dropped by his nurse and his broken leg was discovered too late; he did not survive an operation: "Régis Messac, écrivain, 2 août 1893-19...?" 813: les amis de la literature policière, no. 55, mai 1996, 61-63. Ralph M. also cites Marc Angenot on Messac's heavy use of McGill Library books.

${ }^{178} \mathrm{On}$ Messac's arrest for non-violent assistance to the Resistance and his experience after arrest, see Régis Messac, Lettres de prison, Éditions ex nihilo, Paris, 2005. Interest in his life and work has been ever-increasing: see J.-J. Bridenne, "Hommage à Régis Messac," Fiction (Paris), No. 48, novembre 1957, 133-135; Pierre Versins, Encyclopédie de l'utopie des voyages extraordinaires et de la science fiction, Éditions L'Age de l'Homme S.A., Lausanne, 1972, 585-586; Eric Dussert, "Régis Messac, réformateur contrarié," Le Matricule des Anges, No. 25, janvier-février 1999, 57; Marc Angenot, Préface, Smith Conundrum, Éditions ex nihilo, Paris, 2010; C. Amoz, preface, Messac, Le 'Detective Novel,' Encrage, Paris, 2011; and Natacha Vas-Deyres and Olivier Messac, eds., Régis Messac: un écrivain journaliste à re-connaître, Éditions ex nihilo, Université Michel-deMontagne-Bordeaux3, 2011; as well as frequent articles in Quinzinzinzili, from 2007 on.

${ }^{179}$ Report of Dean of McGill College (Ira MacKay), ca. 1929, Arts and Science, General, 1927-33, MUA, RG2, C58, file 902. From 1929 to ca. 1931, McGill carried out surveys to improve standards, introduce stronger graduate programs, and prepare a fund campaign; the campaign did not take place owing to the Depression. The preliminary draft report of ca. June 1929 (Messac had just left McGill) on the French Department noted that McGill "is strategically situated to develop one of the finest departments of French on this continent.... The staff is quite inadequate to fulfill any such ambition; and here again an outstanding leader of reputation, with an intimate knowledge of French language, literature and history, would add 
materially to the strength of the Department, and with him there should be associated sufficient help to place this Department on a stronger footing and capable of widening the scope of the work necessary to be done both in instruction and in research." The draft perhaps gave insufficient credit to du Roure's teaching flair and successful running of the French Summer School and ignored the shortage of funding which made it difficult to hire eminent staff. See also the Martin-Colby Survey, MUA, RG2, C57, File 830, ca. 1929; also MUA, RG2, C36, file 121 and (Acc 27/1) "Faculty of Arts and Science, Report of the Special Survey Committee, 1930-31," typescript, $165 \mathrm{pp}$. There is further Survey material, ca. 1930-1931 in MUA, RG2, C58, files 875,876 . The files contain much statistical information and commentary on all McGill departments. 


\title{
Principal Sir Arthur Currie and the Department of Chinese Studies at McGill
}

\section{by Macy Zheng}

\begin{abstract}
This article presents a brief history of the Department of Chinese Studies at McGill University. It examines Principal Currie's tireless efforts to create such a department, and discusses various factors - such as the state of international relations in the 1920s and the establishment of the Gest Chinese Library - which motivated him. It describes Currie's search for a Director, his selection of Dr. Kiang Kang-hu for the position, the Department's years of operation, and its eventual closure in 1934.
\end{abstract}

\section{RESUMÉ}

Cet article présente les grandes lignes de l'évolution du Département d'études chinoises de l'Université McGill. Il examine les efforts déployés par le principal Currie pour créer ce département ainsi que certains facteurs qui ont motivé ses actions, notamment létat des relations internationales durant les années 1920 et la fondation de la Bibliothèque chinoise Gest. L'article décrit le processus de sélection d’un Directeur par Currie, son choix du Dr. Kiang Kang-hu, les années d’opération du Département et sa fermeture éventuelle en 1934.

\section{Introduction}

$\mathrm{S}$ ir Arthur Currie is remembered for his distinguished service both as a senior military officer in the First World War, during which he rose to command the Canadian Corps in France, and as Principal of McGill University from 1920 to 1933 . His talent was demonstrated in both of these extremely different jobs. He participated in such notable actions as the Second Battle of Ypres, the Somme, Vimy Ridge and Passchendale, was awarded high honours for his service, and was the first Canadian officer ever promoted to the rank of full general. He was likewise highly successful in his career as Principal of McGill, an office in which he served until the end of his life.

One of the tasks to which Principal Currie devoted much energy and enthusiasm was the establishment of the Department of Chinese Studies at McGill. The history of this department and of McGill's Gest Chinese Library is dramatic and little-known. Very few people realize that McGill established the first Department of Chinese Studies in Canada, preceding both the University of Toronto and University of British Columbia East Asian Studies programs. In his article "The True North Strong: Contemporary Chinese Studies in Canada, Graham Johnson summarizes as follows the history of Chinese Studies in Canada:

Until the mid-1960's, Canada's major universities were few, small, elitist and English-speaking. The University of Toronto, Queen's University in Ontario and McGill University in Montreal were world renowned, but served English-speaking Canada and the Commonwealth, and taught an essentially European-oriented curriculum. Chinese studies were not well represented in them. They were to be found at the University of Toronto and, in the postwar period, at the still small University of British Columbia, in Vancouver in the west. ${ }^{1}$

In Johnson's article, there is no reference to the Chinese Department at McGill at all. In fact, the status of McGill's Department of Chinese Studies as the first such department in Canada, and perhaps even in North America, was largely forgotten until it was examined by $\mathrm{Su}$ Chen and Juming Zhao in their 2004 article "The Gest Chinese Research Library at McGill University 1926-1936"2. The present article will examine this chapter of McGill's history, and in particular Principal Currie's tireless efforts to create such a department at McGill.

\section{Currie's term of office as Principal}

When Currie returned to Canada to great acclaim after the First World War, many people thought he would seek a position in government. Few expected him to become a principal at a university. However, Currie seemed happy to accept such a position at McGill:

On 12 April 1920, Currie received a letter from Frank D. Adams, the acting principal of McGill University in Montreal. The University proposed to confer an honorary doctor of laws degree on Currie at its 12 
May convocation. Currie was only too pleased to accept, unaware that the school had more in mind for him than an honorary degree. ${ }^{3}$

At the keynote address delivered at the Meeting of Western Canadian Deans of Arts and Science in 2004, Michiel Horn said: "By 1933, Currie owed his prominence not only to his war record but also to his position in the academic world. Although he was not a university graduate, he had been appointed Principal of McGill University in 1920. McGill's Board of Governors must have thought that a man who had ably commanded thousands of soldiers would be more than able to hold his own as a captain of the higher learning. They were right." 4

Although a war hero and an intelligent leader, Principal Currie did not have much in the way of academic credentials. He only held a secondary school diploma. It was natural that people thought that his lack of experience in university affairs might be a handicap for him. Nevertheless, the organizational abilities and good judgment which he demonstrated in his work helped him overcome his disadvantage of lacking academic experience. According to an article in the Canadian Great War Project, Currie's administrative ability, which was the basis of his leadership in the War, was turned easily to the service of his new responsibilities at McGill. The article also mentions that, with no professional bias, Currie had a natural ability for choosing the best advisors, and that he brought from the Army the habit of loyally supporting his staff. Under him, McGill prospered anew, materially as well as intellectually. ${ }^{5}$

According to more than forty items of correspondence pertaining to the Chinese Department and the Gest Chinese Library which are preserved in the McGill University Archives, Currie applied the same vision, fairness in judgment, passion and ability in creating the first Department of Chinese Studies in Canada, and in finding the most brilliant Chinese scholar to lead the department. It is remarkable that a Principal, with so many other tasks to handle, would spend so much time and energy on this issue. We should also bear in mind that the Department of Chinese Studies was established during the Great Depression, at a time when McGill was in a difficult financial situation. Currie's eagerness to build a Chinese or Far Eastern Department is illustrated by his letter to Dr. Nicholas Murray Butler, President of Columbia University, which says: "It is strange that in your last paragraph you use phrases which have been in my mind and on my lips for many years. I have longed to build up at McGill a strong Department of Far Eastern Studies." ${ }^{6}$

\section{Currie's motivations in establishing the Department}

Why was Currie so anxious to establish the Department of Chinese Studies? Perhaps the following factors provide some explanation:

Currie, who had witnessed first-hand the horrors of combat, detested war. He believed that "War is not a means to establish peace. It is a delusion and a lie". He hoped war would not happen again, and he tried to find ways to maintain peace. He strongly believed that after World War I European domination of the world would be diminished and the status of other regions, especially Asia, would increase. $\mathrm{He}$ felt, however, that people in the West lacked knowledge and understanding of people in the Far East, and China in particular. He believed that universities should provide courses in area studies, such as Chinese studies. In his letter of 1932 to the Secretary-General of the League of Nations in Geneva, Currie said: "Believing, as we all do, that intellectual co-operation and mutual understanding contribute largely to international peace, we felt that such a development might in the end have a value apart from its cultural importance." He thought that the time was ripe for such a development in Canada. He found that occidental nations were realizing more and more fully the historical and cultural connection

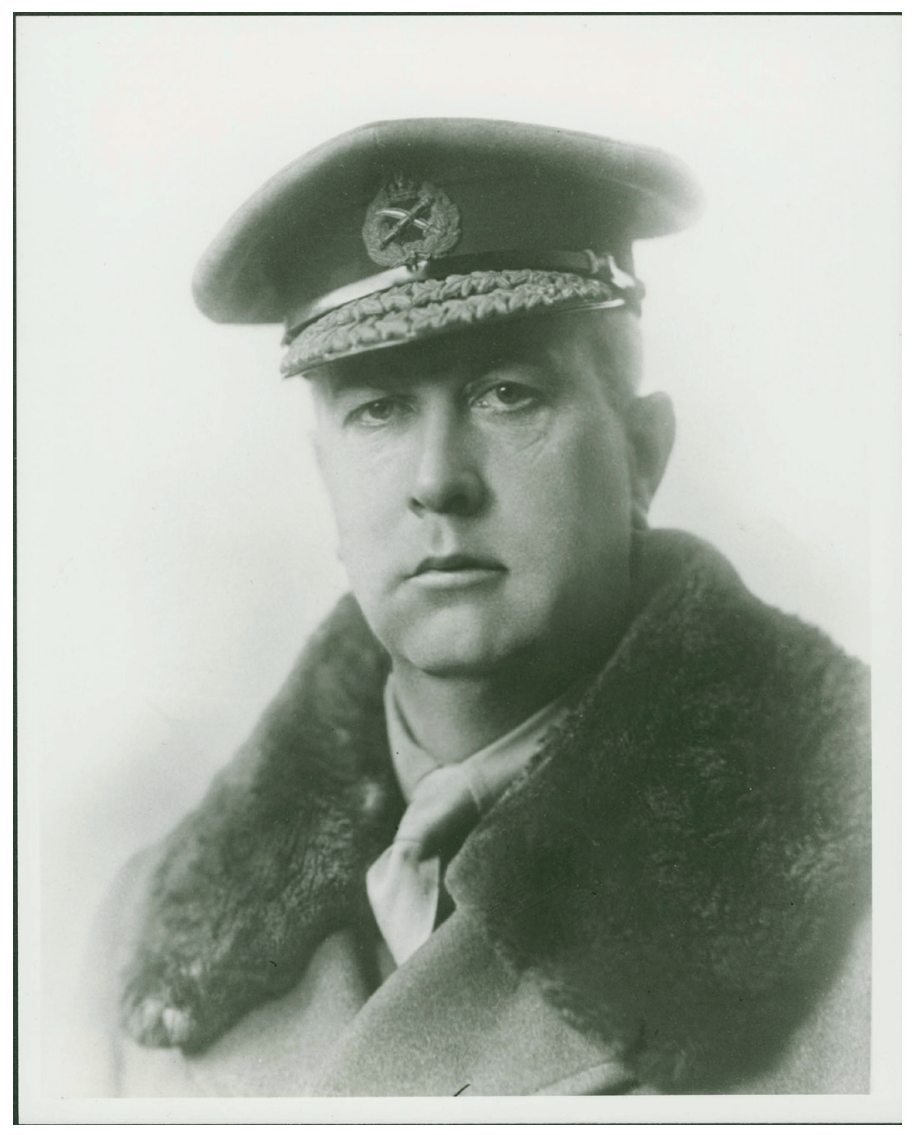

Figure 1. Portrait of Sir Arthur Currie. Black and white photographic print, 1917. Photographer: unknown. McGill University Archives, PR041486 
between China and the West, and were beginning to value and taken an interest in Chinese literature and Chinese culture.

From the economic and political point of view, he thought that by reason of the short Northern Pacific trade route, Canada was a nearer neighbour to China than any other western country. Since Canada's commercial contacts with China were increasing and since no political questions separated the two countries, Canada was an eminently suitable place for a new school of Chinese Studies.

In addition, a historical event played a role in the establishment of some Chinese programs in North America in the early $20^{\text {th }}$ century. Following the Boxer Rebellion, ${ }^{9}$ the Qing Dynasty government was pressed to pay a fine of over US $\$ 300$ million to the Eight-Nation Alliance. ${ }^{10}$ One of the members of this Alliance, the United States, ended up receiving more money than had been intended; the U.S. government eventually decided to use the difference to create a Boxer Rebellion Indemnity Scholarship Program, whose purpose was to assist Chinese students to study in the States. The United Kingdom later set up a similar program.

In his letter to Edward Beatty, the President of Canadian Pacific Railway, Currie wrote:

We have recently been exploring the possibility of making some contribution to the establishment of closer relations between Canada and the trans-Pacific nations. The matter has had the careful attention of members of the staff and has been discussed with the Governor General, who was, as you know, the Chairman of the British Delegation which visited China in connection with the remission of the Boxer Indemnity. Such consideration, as we have so far been able to give the subject, leads us to think that the work to which we may best set our hand is the establishment of certain courses connected with China and the political and economic relationships between China and our country. ${ }^{11}$

I hope that a certain amount of assistance will also be received from the Trustees of the Boxer Indemnity Fund. This fund, in accordance with the still unpublished report of the Advisory Committee, will be administered by a board of trustees of which the majority will be Chinese, and part of it will be devoted to some thirty scholarships of $£ 300$ each and a number of fellowships of $£ 500$. As the report originally read it provided that the students holding the fellowships should receive their training in the universities of England, but as a result of communications between ourselves and the Governor General an effort is being made to have the report include Dominion universities. ${ }^{12}$

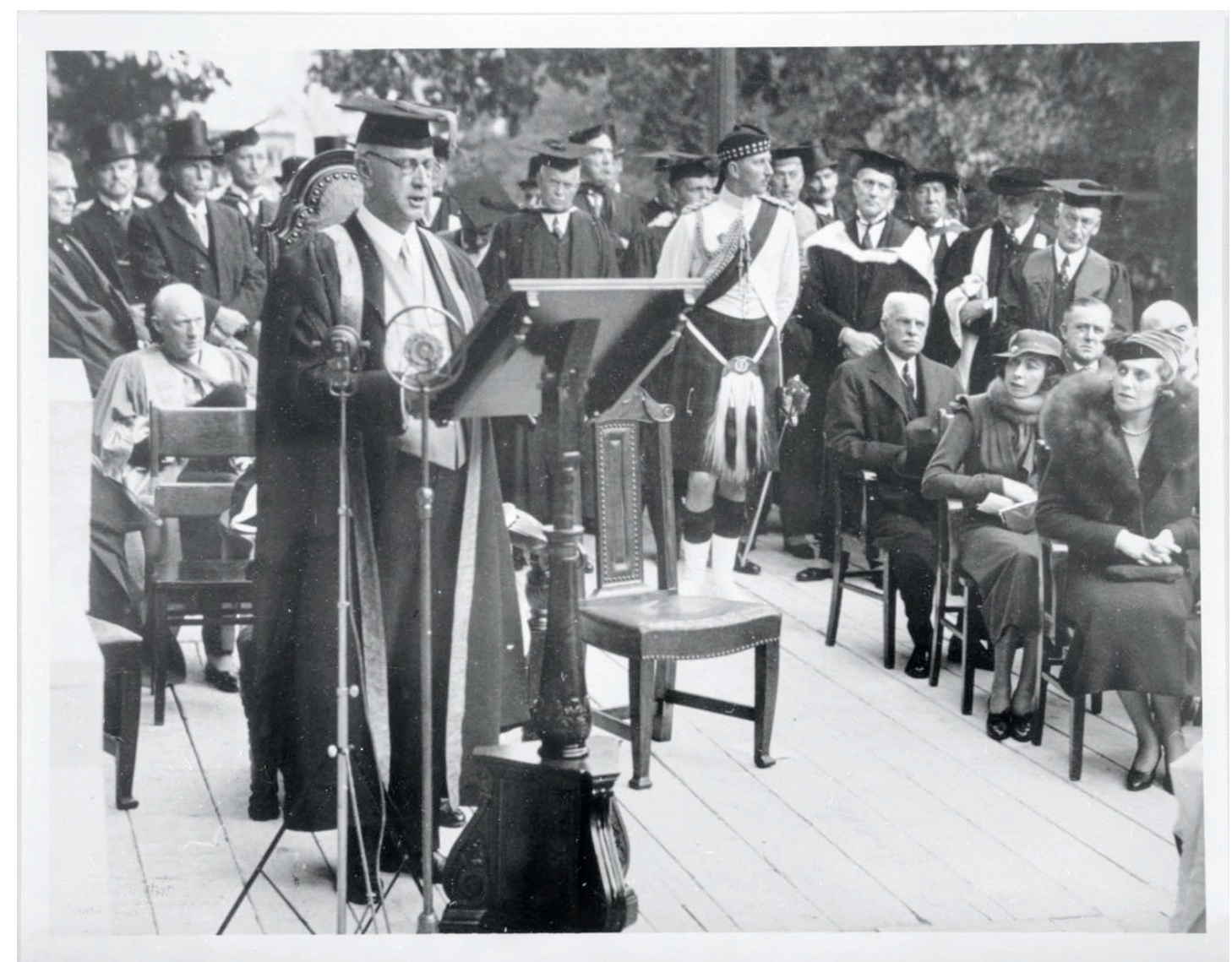

Figure 2. Sir Arthur Currie addressing a crowd at convocation, 1930. Black and white photographic negative, 1930. Photographer: unknown. McGill University Archives, PN029151 
Currie added the comment:

We feel assured that if such a department as we propose can be established on a proper footing, its work would be of the greatest value to the country at large. ${ }^{13}$

Currie's point of view on promoting Chinese studies was supported by other leaders at McGill. Wilfred Bovey, McGill's first director of Extra-mural Relations and Extension, explained the significance of setting up Chinese programs in the March 1927 issue of the News Bulletin of the Institute of Pacific Relations. He stated that only in recent years had universities in general recognized the importance of adequate historical studies and accepted the doctrine that the knowledge of the growth and relationships of peoples was in itself an education. Now that the relations of the Asian and European peoples were undergoing such great changes, the history of Asia could not be allowed to remain the closed book which it had long been to Westerners, and there were no more important portions of this book than the chapters which held the story of the Chinese Empire. ${ }^{14}$

Bovey further mentioned that Canada had assumed her place in the arena of international affairs, and that McGill University too had begun to think internationally. Therefore, the University had decided to include in the curriculum the study of Chinese literature, history and philosophy and of China's economic and political relations. It had recognized that western culture was not the only basis of education, that the literature and the philosophy of the Far East had a value of their own. It had also recognized that the twentieth century had created a new group of nations, a group centered on the Pacific Ocean, and that much of the future history of the world would be written around the commercial and political intercourse of the countries bordering that great sea. ${ }^{15}$

Bovey emphasized that the task of assuring understanding between East and West was one of paramount importance at that time, and one in which all must bear their part. The fruit of these labors would not be gathered the same season or next, but mutual knowledge would in the end bring with it friendship and respect. The education and intellectual co-operation at which McGill and the Institute of Pacific Relations were aiming would be a great agency for the cause of peace on earth. ${ }^{16}$

Other academic organizations also started to promote oriental studies following the First World War. For example, the American Council of Learned Societies, founded in 1919, established the Committee on the Promotion of Chinese Studies. Similarly, an ongoing series of conferences and research programs on East-West issues was sponsored by the Institute of Pacific Relations, an independent international organization formed in 1925. Such associations might have encouraged Currie's determination to set up a Chinese Department at McGill.

\section{The Gest Chinese Library}

One asset on which Currie was able to capitalize was the Gest Chinese Library, which became an official McGill library in 1926. This rich resource was developed by Mr. Guion Moore Gest, and was housed in the Redpath Library. Its collection was of the best quality ever collected in North America, and it became the largest Chinese collection in North American universities. ${ }^{17}$ Berthold Laufer, an Asian studies expert, provided the following description of the Library:

The Gest collection is housed in the attractive library building of McGill University, where it occupies a large room on the second floor. The stacks are of steel, arranged in two stories, the upper one being entirely devoted to the great cyclopedia $\mathrm{Tu}$ Shu Tsi Chieng. The arrangement of the books is so systematic and splendid that any book can be traced at a moment's notice. The photographs taken by Mr. Gest himself in the Orient adorn the walls. The floor is laid with Chinese rugs, and Chinese antiquities in a glass cabinet. ${ }^{18}$

$\mathrm{He}$ also outlined the content of the collection:

The library is at present well equipped for research work. It is especially strong in dictionaries, historical works, catalogues, encyclopedias, and medicine. One of the greatest treasures of Mr. Gest is an extensive collection of sutras from a Tripitaka edition which were obtained in a remote part of China. ${ }^{19}$

Currie devoted much time and attention to obtaining the Gest Library for McGill and to ensuring the library's subsequent development and survival. In his letter to Edward Beatty, the Chancellor of McGill, Currie expressed his desire to better use the library:

In connection with the Department of Chinese Studies, we could make much fuller use than is now possible of the magnificent research library of which we have come into possession. ${ }^{20}$

In his letter to Dr. Keppel, the President of the Carnegie Foundation, Currie further stated his aspiration of making full use of the library:

I have always felt that the best use to make of library, in its earlier days, was to develop an interest in and a knowledge of Chinese Civilization. I felt that in using the Library in this way, we were opening a door to a knowledge of a civilization of which we know altogether too little. ${ }^{21}$

Ever since the establishment of the Gest Library, Currie was proud that McGill had such a Chinese library and he invited many dignitaries to visit it. From his home in what is now McGill's Faculty Club, he must have enjoyed looking across the street at the original Redpath Library, which housed the prized Chinese collection. 
In 1931, Currie spent several weeks visiting China, Japan and India. He mentioned this in his letter to Mortimer Graves, Secretary for the Committee on the Promotion of Chinese Studies:

We appreciate our good fortune in having the Gest Chinese Research Library at McGill and are anxious that opportunity should be given for the greatest possible use of the facilities available. I spent about three weeks in China during my recent visit to the Orient and come away with the impression that a greater degree of stability is now apparent than has been evident for years. We can hardly over-estimate the value of serious Oriental studies in our Western universities.22

\section{Planning the establishment of the Chinese Studies Department}

Although the Chinese Studies Department was not officially established until 1930, Currie had considered this matter many years earlier. In his letter to Dr. Frederick P. Keppel, the president of the Carnegie Foundation, Currie wrote:

Ever since coming to McGill University as Principal in 1920, I have been interested in the education of Chinese students in Canada. I remember that when I was a member of a Committee of the Canadian Universities Conference on the question of the education of Chinese students in Canada, the matter was very thoroughly gone into. Furthermore, my Chancellor, Mr. Beatty of the Canadian Pacific Railway, was also interested. ${ }^{23}$

Earlier, on November 17, 1926, Currie wrote to Beatty:"

We are not yet prepared to put forward a defined plan of organization, but so far as we can see at present it would be necessary to establish a Department of Chinese Studies in which the student might be furnished with a background of Chinese history, literature and philosophy, and to treat at the same time the more clearly defined economic questions, interesting both China and Canada, in the Department of Political Economy. In connection with the Department of Chinese Studies, we could make much fuller use than is now possible of the magnificent research library of which we have come into possession. ${ }^{24}$

Currie hoped that the students would be of several categories:

1. Canadian or British students preparing themselves to go to China for employment in Commerce.

2. Canadians intending to be missionaries.

3. Chinese students coming from China.

\section{Chinese students living in Montreal..$^{25}$}

From this we can see that Currie not only had a plan in mind to set up the Chinese Department but also that he had considered the details of its implementation.

Currie submitted his proposal for the formation of a Department of Chinese Studies to McGill's Board of Governors on December 20, 1926. The Board approved the plan in 1927. In the three years which elapsed between this date and the actual establishment of the Department in 1930, however, much planning still had to be done. This work included consulting professors from the departments of History, Economics, Philosophy, and Literature on various aspects of the project.

One of the individuals who provided input was Wilfrid Bovey, the Director of Extra-mural Relations and Extension, who was greatly valued by Currie. Bovey envisioned that education on Chinese culture and civilization would be carried out in the new Chinese Department, and that courses on China would also be offered in the Department of Political Economy. Bovey, like Currie, regarded the Gest Library as a perfect resource for students in this field.

Currie's involvement in setting up the Chinese Studies Department included such elements as searching for its chairman and other teaching staff and considering their salaries. Currie discussed some of these issues in a letter to Mr. Beatty:

Mr. G. M. Gest is, as you are aware, already providing for the salary of the librarian and for the time being of an assistant. In addition to this we should require sufficient funds to meet the salaries of the teaching staff. We can save a certain amount by utilizing the services of men already with us, to whom however we should have to pay a little more than at present. We should require one new instructor who would take charge of the Department of Chinese Studies. Possibly it might be as well to have a Chinaman, if we could procure one of sufficient eminence. ${ }^{26}$

\section{Searching for a chairman}

Currie's letter to Beatty reflects the fact that he and Bovey both wanted the Department of Chinese Studies to be headed by a scholar capable of bringing to Westerners a new appreciation of the oldest of civilizations. A difficulty faced by Currie in this regard was that, at that moment, there were no scholars of international repute in this field at McGill. It was suggested that this problem could be resolved through an exchange of professors between McGill and one of the leading universities in China. This plan, however, does not seem to have been carried out successfully. The difficulty of finding the right professors for the new unit explains in part why the Chinese Department was not established until 1930. 


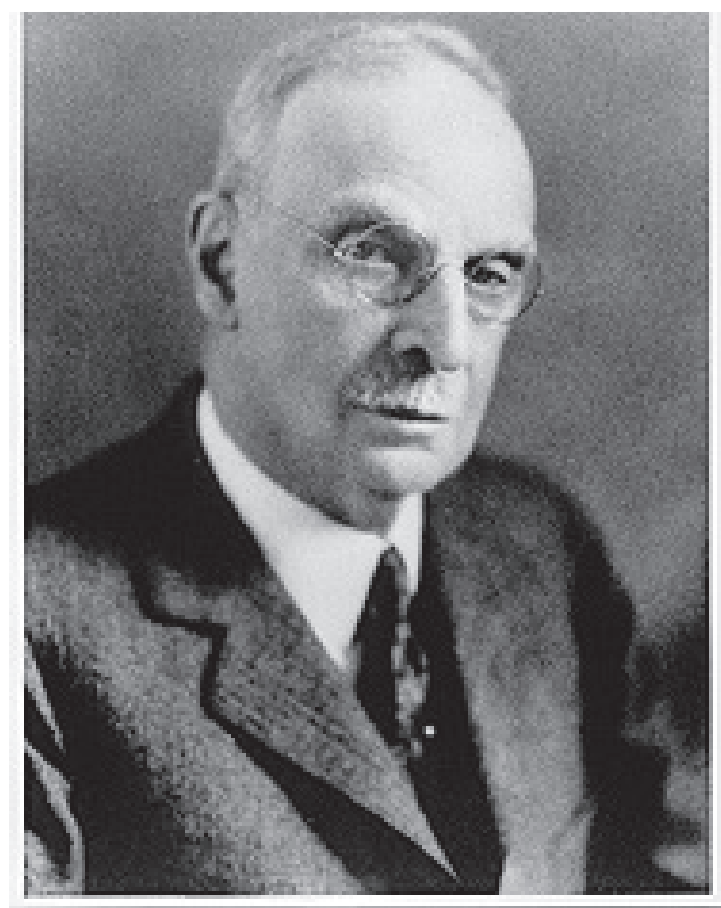

Figure 3. Picture of Mr. Guion Moore Gest (1864-1948) from Princeton University East Asian Library's website: http://eastasianlib.princeton.edu/history.htm. Accessed Dec 17, 2011

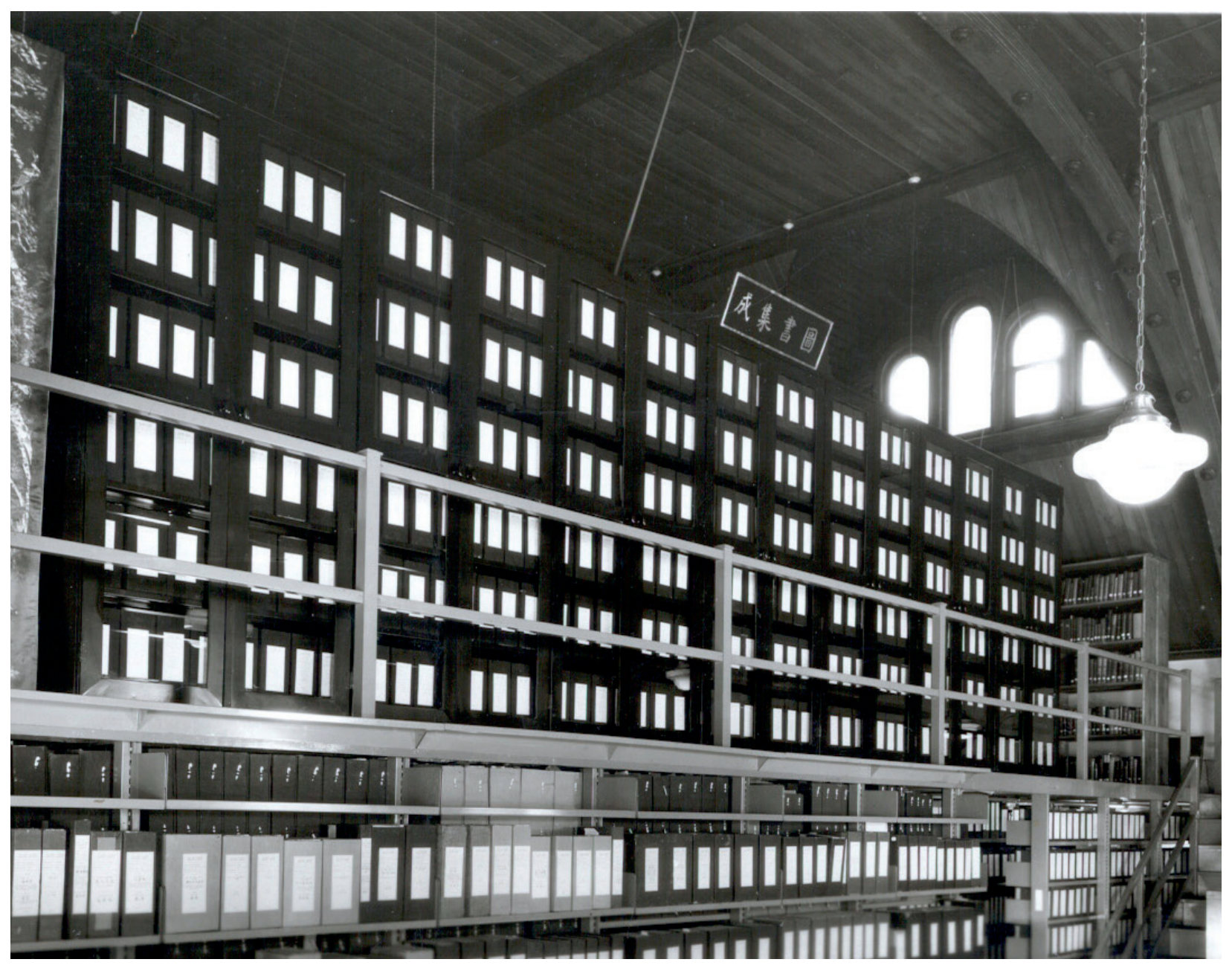

Figure 4. Gest Chinese Research Library, Redpath Library, McGill University, 1931. Photographer: Rice. McGill University Archives, PR026617 
Currie personally handled the task of interviewing and comparing candidates for the position of the chair. According to Dorothy McMurray, the Principal's secretary, Currie felt that the selection of teachers was his responsibility: he would seldom hire a new professor, or even a lecturer, without having interviewed the candidate to assure himself that the individual was, in addition to being highly recommended by academic authorities, someone who was worthy of McGill and who would enhance the University's good name. ${ }^{27}$ His search for a suitable individual for this position, which began in 1927, was initially disappointing, as he mentioned in his letter to Mr. Gest: "On investigation the majority of them have been found wanting. Some of them were little better than newspaper correspondents and journalists who had written much about China without any profound knowledge of the subject."28 His frustration was also shown in his letter to Mr. Berthold Laufer: "We are very proud of the Gest Chinese Research Library and regret that up to the present we have had no success in picking upon a suitable man to lead the Department of Chinese Studies which we would like to set up." 29

The man eventually chosen by Currie in 1930 to head the Department was Dr. Kiang Kang-Hu. Kiang accepted this position and declined another one in the United States which offered him much higher salary. In his letter to Currie, Kiang said that his decision was made not by weighing material gains. ${ }^{30}$ Kiang was recognized as being both intelligent and knowledgeable in the field of Chinese studies, and Currie was gratified to have been able to recruit him. He was, however, a controversial figure in the political history of modern China, for reasons we will discuss briefly.

\section{Kiang Kang-Hu's background}

Kiang Kang-Hu was born to a high official family in Kiangsi, China in 1883. His father and his grandfather both took the third and highest degree of the old style Chinese examination, and were appointed to the Hanlin Academy, which was the highest scholastic rank under the old Chinese system. He was a gifted student, and apart from Classic Chinese, he had a solid command of the Japanese and English languages at a young age. He went to Japan to attend the Imperial University at Tokyo in 1900 when he was seventeen years old. He held posts in the imperial ministries of justice and education between years of 1900 and 1910; taught Japanese language and Chinese history at Peking University between 1905 and 1910; and founded the Chinese Social-Democratic Party in 1912. From 1914 to 1920 , he taught Chinese language and civilization at the University of California. Kiang later returned to China to teach at Nanjing, and worked on various constitutional committees for the republican government. He came back to America in 1926, and was hired as a Chinese consultant for the Library of Congress in 1928 . He was appointed Chairman of the Department of Chinese Studies at McGill in 1930.31
Kiang was politically active and he was considered the first person to introduce socialism to China. He organized the Chinese Socialist Party to promote socialism and became its leader. In his book Red Star over China, Edgar Snow, an American journalist, mentioned that Chairman Mao Zedong told him that Mao had first learned about socialism from Kiang Kang-Hu when he was a college student: "I read some pamphlets written by Kiang Kang-Hu about socialism and its principles. I wrote enthusiastically to several of my classmates." ${ }^{32}$ Kiang was even said to have had the chance to meet Vladimir Ilyich Lenin and Joseph Stalin in the Soviet Union. ${ }^{33}$ However, his party was banned by the Yuan Shikai government in 1913; his arrest was ordered, but he managed to flee to the United States.

It seemed that during his years in North America, Kiang focused more on academic teaching and research than political activities. During this time, Kiang worked at University of California at Berkeley, the Library of Congress and eventually McGill. He donated over 10,000 volumes to the library at Berkeley, which became the basis for Berkeley's establishment of its East Asian Library. Kiang gave many lectures about Chinese literature and culture on various occasions in the United States and Canada. He also wrote a number of books on Chinese history, culture and politics in Chinese, Japanese and English, and collaborated with the American poet Witter Bynner on Jade Mountain, a volume of translations of Chinese poems.

In contemplating the appointment of Kiang as chair of the Department of Chinese Studies, Currie was very satisfied with his qualifications but realized that his political background might be problematic. He therefore did his best to ensure that Kiang's earlier political activities did not cause him any trouble. When Currie discussed Kiang with Mr. Gest, the latter expressed his satisfaction with the appointment of Kiang, stating that he had heard nothing but the best reports regarding his scholarship. Gest did, however, draw Currie's attention to the fact that Dr. Kiang was at one time a very prominent supporter of the Kuomintang party, that he had been to Moscow to investigate Bolshevism, and that he had at one point been viewed as slightly Communistic. Currie informed Mr. Gest that he had discussed this matter with Kiang, who had told Currie that when the revolution in China came all Chinese became interested in all revolutions. Kiang had said that there was a great deal of Communistic propaganda in China and that he had gone to Moscow to study Communism for himself, but that he had come away with the opinion that it would not do for China. ${ }^{34}$

\section{The Department of Chinese Studies during its years of operation}

The Department of Chinese Studies became a reality in 1930. It was recorded in McGill's Annual Report of 1930-1931: 
At the beginning of the session under review the Faculty of Arts added a new department, that of Chinese Studies. The presence at McGill of the Gest Chinese Research Library, one of the bestequipped Chinese libraries outside China, made the establishment of this department highly advisable. Canada is situated on two seas, the Atlantic and the Pacific, and the relations between the Dominion and the Orient will inevitably become of increasing interest in the future. Universities are essentially international institutions and the influence of universities on international relations is very much greater than usually imagined. In order that Canadians may have suitable facilities for learning something of Chinese history and geography, Chinese government and social institutions, Chinese philosophy and religion, literature and art, some Canadian university had to lead the way. ${ }^{35}$

McGill University thereby became the first Canadian educational institution to house a Chinese Department, with a Chinese scholar as a full professor for its chair.

Under Kiang's guidance, the Department of Chinese Studies offered regular university courses to students of second year or higher standing in the Faculty of Arts and Sciences. A lecture course on Chinese culture in general was given in English as an introduction to all branches of Chinese studies. It outlined Chinese history, geography, government and social institutions, philosophy, religions, literature and art in a series of lectures completed in two academic years of three hours per week. All materials were drawn from Chinese sources and interpreted from the Chinese viewpoint. Language classes were open for elementary and advanced students. Chinese readers in Kuo Yu (Mandarin language) were used, with well-selected characters. ${ }^{36}$

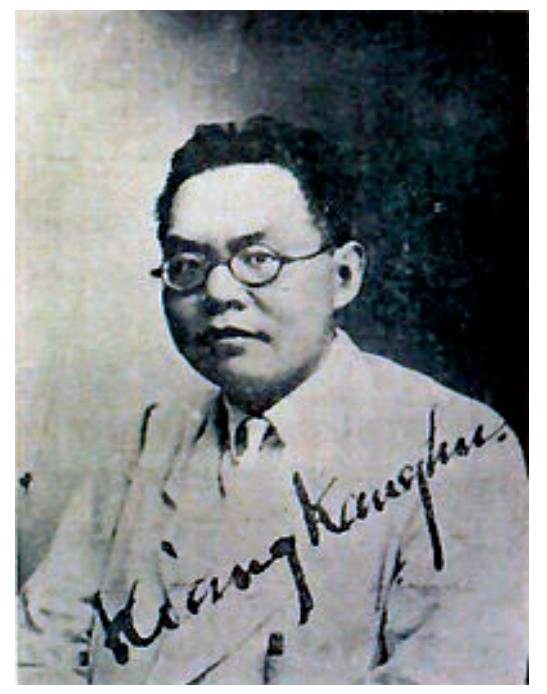

Figure 5. Kang-Hu (1883-1954). Picture from website of Baidu: http:// baike.baidu.com/view/477462.htm. Accessed December 17, 2011 Kiang
Brush-stroke calligraphy was also part of the curriculum. For advanced students there were courses in reading Chinese classics in the original text, as well as modern documents and newspapers. Translations from spoken Chinese (bai hua wen) to written Chinese language (wen yan wen), and from Chinese into English were taught. Research on special topics was carried on by special arrangement, with reference readings in the Gest Library and submission of periodical reports or papers. ${ }^{37}$

Beginning in 1932, the Department also offered graduate courses in Chinese studies. Any qualified student holding a B.A. degree who had a workable knowledge of either the Chinese written or spoken language, or both, might take these courses as a major or minor subject and work towards the M.A. degree. Since only second or higher year students of good standing in other subjects were allowed to elect the Chinese courses, the enrollment had not been very large. For the initial two years about one hundred names were registered with the department in various classes. ${ }^{38}$

Although the Gest Chinese Research Library already existed, a small Department Library was set up to provide additional materials in the form of popular and indispensable Chinese books for the constant use of its staff and students. There were over 500 items of modern Chinese works and reprints of old works in all the four main Chinese library classification groups. A large number of Chinese pamphlets, periodicals and daily papers were being received from China and the Chinese communities abroad. The objective of this library was to supplement rather than duplicate the Gest collection. Kiang believed that in the years to come this departmental library, started in a very humble way, would grow in size and usefulness. ${ }^{39}$

In 1931, with the co-operation of the Department of ExtraMural Relations, Kiang organized the Hung Tao Society of Montreal as a branch of the parent society in China, for

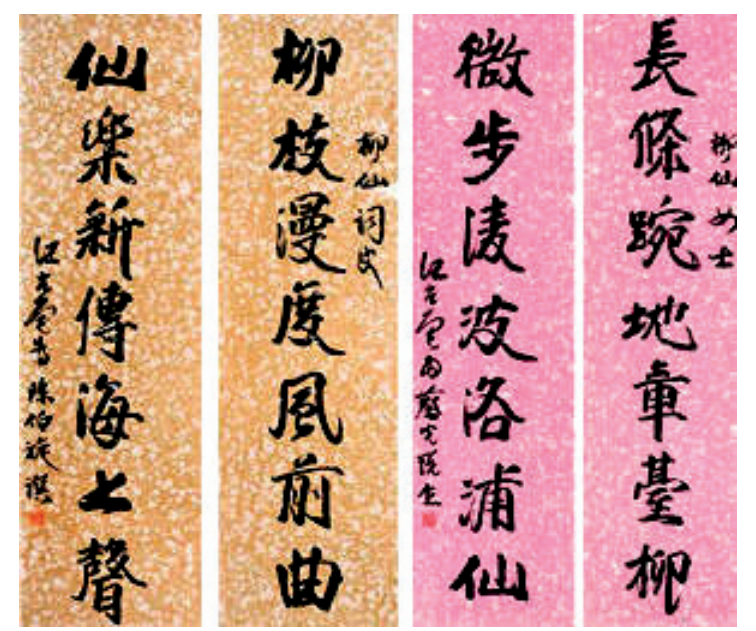

Figure 6. Kiang 's calligraphy. Picture from website of Baidu: http://baike. baidu.com/view/477462.htm. Accessed December 17, 2011 
the diffusion of Chinese thought and the popularization of Chinese philosophy. It was found necessary to form two sections, one for the Canadians and English-speaking Chinese and the other for the Chinese-speaking Chinese. There were eight lectures in each section throughout the academic year on cultural subjects, and a number of special and social meetings at which Chinese teas and dinners were served. In the Chinese section there were also lectures on the modern Chinese language. Over two hundred Canadians and one hundred fifty Chinese paid membership fees, and a large number of them were regular attendants at the meetings of the Society.

Resolutions were passed to establish two scholarships at McGill, one for a Canadian student in the Chinese Department and the other for a Chinese student in the University, having regard in both cases to the academic achievements of the students and to his or her financial needs. Extension classes, both cultural and linguistic, were scheduled for the first time in the fall of 1932, and according to University statistics for the first two years of the department's operation, Professor Kiang had the largest number of outside lectures among the faculty staffs - a reflection of the growth of public interest in the field of Chinese studies on this continent. ${ }^{40}$

Currie's correspondence makes it clear that he was very satisfied with the performance of Kiang as the chair of the department. In a letter he wrote in 1931 to Prince Amoradat Kridakara of Siam (now Thailand), he said:

We have set up at McGill University a Department of Oriental Studies, presided over at present by Dr. Kiang Kang-Hu, an eminent Chinese scholar. Besides giving instruction in the Chinese language, philosophy, history, and literature, he lectures in a general way on all Far Eastern affairs. We have established the Department because of our conviction that it is wise for us to know something of the civilization of the Far East, their history and development. ${ }^{41}$

Another example of Currie's high regard for Kiang can be found in a 1932 letter to the Secretary-General of the League of Nations, in which he wrote:

The University decided to undertake the organization of a Department of Chinese Studies. We decided, at the same time, that other things being equal, it was desirable that the Department should be headed by a Chinese scholar, just as our Department of Romance Languages is headed by a French scholar. After long search, during which appeal was made to almost every known sinologist, we obtained the services of Dr. Kiang Kang-Hu, a renowned scholar of Northern China, know and recognized through that country and Japan as a pre-eminent authority on the Chinese classics and holder of the ancient Han Lin degree. Under his leadership, the organization of the Department has been carried out. ${ }^{42}$

He commented on this appointment with evident pride:

So far as I am aware, this is the only Department of an Occidental university concerned with Chinese studies which is headed by a Chinese scholar with the rank of full professor, and in which extension work is actually carried on among Chinese-speaking people. ${ }^{43}$

Currie expressed similar sentiments in a 1933 letter to Dr. Keppel, which states:

Then, three years ago, I engaged a professor of Chinese Studies, Dr. Kiang Kang-Hu, who, I think it will be admitted, is one of the greatest Chinese scholars of China. In the three years he has been here, Dr. Kiang Kang-Hu has been successful in building up the Department of Chinese Studies. It can never be a large department, of course." ${ }^{34}$

\section{Death of Currie and closure of the Chinese Department}

In his book Sir Arthur Currie: a biography, Daniel Dancocks describes Currie's final days:

The first weekend of November 1933 had begun well. On Friday, before leaving the office, Currie had joked with Mrs. McMurray about his health. He had assured her that he felt fine-never better, in fact-and predicted that "I can count on a good ten year yet. ${ }^{45}$

"On Sunday, 5 November, Currie was working at home. He was in the study, composing his annual

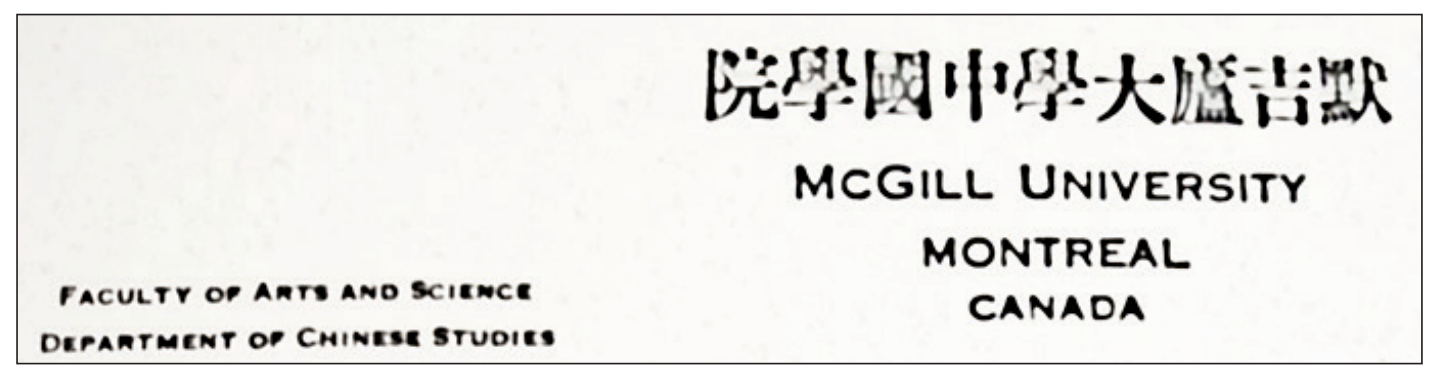

Figure 7. Letterhead of the Department of Chinese Studies. Letterhead in a file of RG2, C69. The McGill University Archives 
Armistice Day message, but he did not complete it. Currie collapsed and was later taken to the Royal Victoria Hospital. ${ }^{46}$

Currie passed away on November 30th, 1933, a few days after the 15th anniversary of the Armistice, at the relatively young age of 58 .

The Chinese New Year celebration came soon afterwards, and at the request of $\mathrm{Mr}$. Gest, it was decided, out of respect to the late Principal, to omit the Chinese New Year's tea party. It was on the occasion of the Chinese New Year's Day on February 13, 1926, that the Gest Chinese Research Library had first opened to the public. Since that date, upon the recurrence of the old Chinese festival season, a tea party had been customarily held each year in the Library, and Currie would be invited to the celebration.

McGill did not have a Principal for about two years following Currie's death, and Edward W. Beatty, the Chancellor of McGill, served as unofficial Principal. ${ }^{47}$ On July 5, 1934, the Board of Governors accepted a recommendation from the Finance Committee and decided to discontinue the Department of Chinese Studies:

Upon the recommendation of the Finance Committee, as a measure of economy the Board of Governors decided to discontinue the Department of Chinese Studies and to withdraw financial support from the Gest Chinese Research Library. This Department was founded in 1930 under the direction of Dr. Kiang Kang-Hu, and has made a valuable contribution towards the promotion of Canadian interest in Chinese culture, history and civilization. It is regretted that funds are no longer available for its continuance. ${ }^{48}$

The Board informed Kiang that his contract with McGill had been terminated. ${ }^{49}$ At that time, Kiang was in China taking one year of unpaid leave. Responding to McGill's notice of dismissal, Kiang wrote: "I do not complain for the discontinuance of the Chinese Department nor do I beg for any special favor, but I cannot understand how a professor can be so slighted and ignored by an institute of McGill's standing. I am doubly sorry for this treatment since the University has shown me great consideration and I have repeatedly pledge undivided service." 50

After his dismissal from McGill, Kiang stayed in China for the rest of his life. He became involved in politics once again, at the cost of further troubles. In contrast with his earlier political orientations, he now began working for the pro-Japanese Wang Jingwei regime. At the end of the Second World War, he was captured by the Nationalist Chinese government and sentenced for treason to life in prison, where he died in 1954.

In May of 1946, Mrs. Kiang wrote a letter to Principal Frank Cyril James. ${ }^{51}$ In her letter, Mrs. Kiang said that her husband was not a criminal, and she had contacted many friends for her husband's rescue, but failed. Now she had to appeal to Principal James in the hope that Kiang's past services and contributions at McGill might prompt James to offer some help in this regard. ${ }^{52}$

James immediately replied to her:

Your letter of May $28^{\text {th }}$ has been received, and naturally all who knew you and your husband during the brief time he spent at this University will be indeed sorry to hear of his present difficulties. Since I was not in office then, however, I could not personally take any action such as you suggest, but I do know that some of my colleagues who knew him were at one time instrumental in helping him out of somewhat similar troubles and I will make inquiries and see what the situation may be at present as regards forwarding an appeal on his behalf..$^{53}$

At the same time, James wrote to Bovey:

I am attaching for your perusal and return to me a letter from Mrs. Kiang concerning her husband, the former Professor of Chinese Studies here. Mrs. McMurray tells me that some years ago he got into similar difficulties and that you were instrumental in saving his life. She is also of the impression that since then it became known to the local Chinese community leaders that he actually was a disloyal Chinese and was cooperating with the Japanese puppet government. This was some years ago possibly before 1940, but if it is true it would land colour to the charges on which he is at present imprisoned. I should be glad to hear from you, with the return of the letter, as to whether you think you should take any further steps on behalf of the University in this matter. $^{54}$

Bovey wrote back to James, saying that he did help Kiang successfully the previous time and he was released. But ordinary diplomatic channels would be of no value in the present case. Bovey said that his feeling was that Kiang was too impractical a man to have been involved in a real plot, and he knew that Kiang felt in his heart that Chinese culture was immeasurably superior to Japanese. ${ }^{55}$

\section{Conclusion}

Currie once said in a letter to Frederick P. Keppel: "I always dreamed that here at McGill we might set up a Department of Far Eastern Studies, to include a study of Purdon, Indian, Chinese and Japanese civilization." ${ }^{16}$ Although Currie fulfilled his dream of establishing the Department of Chinese Studies, the unit he had worked so hard to create did not survive him for long. The Gest Chinese Library soon suffered a similar fate: two years after the closure of the Chinese Department, 
financial and other reasons resulted in the move of the Library to Princeton University.

Currie's remark that the Department of Chinese Studies could "never be a large department, of course" proved to be an accurate-indeed, an overly optimistic-prediction for the decade that had seen its establishment. In 1968, however, thirty-four years after the Department's closure, the formation of Department of East Asian Studies marked not just the return of Chinese studies to McGill but also the extension of the University's teaching and research activities into the realm of Japanese and Korean studies. Principal Currie would no doubt have been pleased to know that, one day, Far Eastern Studies would be pursued at McGill with an even greater scope than he was able to witness in his own lifetime.

\section{Acknowledgements}

I would like to thank my colleague Marc Richard for his assistance in editing the draft of this article and for translating into French the abstract and my biographical sketch.

I would also like to express my deepest gratitude to Ms. Theresa Rowat, Ms. Mary Ellen Worgan Houde and other staff at the McGill University Archives for helping me access related documents for my research.

\section{Notes}

To prepare this article, I have also consulted documents RG32 "Correspondence and lecture: Kiang Kang-Hu", and documents in MG 4025 at MUA, which includes photos, business cards, postal cards, students' examinations, receipts of books purchased for the Chinese Department, etc. Not much information in these files is directly related to the content of this article.

\section{ENDNOTES}

${ }^{1}$ Graham E. Johnson, "The True North Strong: Contemporary Chinese Studies in Canada" The China Quarterly, 1995, p. 851-866.

${ }^{2} \mathrm{Su}$ Chen and Juming Zhao. "The Gest Chinese Research Library at McGill University, 1926-1936." The East Asian Library Journal, v. XI, no. 2 (Autumn, 2004), p. 40-99.

${ }^{3}$ Daniel G. Dancocks, Sir Arthur Currie: a biography. (Toronto: Methuen, 1985), p. 206.

${ }^{4}$ Keynote address delivered at the Meeting of Western Canadian Deans of Arts and Science. History of Intellectual Culture, 2004, retrieved from : www. ucalgary.ca/hic/files/hic/horn.pdf. PDF file

${ }^{5}$ Canadian Great War Project, http://www.canadiangreatwarproject.com/ transcripts $/$ transcriptDisplay.asp? Type $=\mathrm{N} \& \operatorname{tran} s \mathrm{No}=303 . \quad$ Accessed December 17, 2011.

${ }^{6}$ Currie to Butler. May 8, 1933. RG2, C.69, File 1386, McGill University Archives.

${ }^{7}$ Robert H. Michel, "The General Portrayed: Sir Arthur Currie and His Painters." Fontanus, vol. 7 (1994), p. 73.
${ }^{8}$ Currie to the Secretary-General, the League of Nations, Geneva, October, 27, 1932. RC2, C69, McGill University Archives.

${ }^{9}$ The Society of Righteous and Harmonious Fists", known as "Boxers" in English, led a rebellion in China between 1898 and 1901 against foreign imperialism and Christianity.

${ }^{10}$ The Eight-Nation Alliance was an alliance of nations made up of AustriaHungary, France, Germany, Italy, Japan, Russia, United Kingdom and the United States.

${ }^{11}$ Currie to E.W. Beatty, President, Canadian Pacific Railway. November 17, 1926, RG2, C59, McGill University Archives.

${ }^{12}$ Ibid.

${ }^{13}$ Ibid.

14"Department of Chinese Studies: McGill University". News Bulletin (Institute of Pacific Relations). March 1927. p.13.

${ }^{15}$ Ibid.

${ }^{16}$ Ibid.

${ }^{17}$ For details about Mr. Gest and the library, please refer to Su Chen's "The Gest Chinese Research Library at McGill University, 1926-1936." The East Asian Library Journal, v. XI, no. 2 (Autumn, 2004), p. 40-99.

${ }^{18}$ Berthold Laufer, The Gest Chinese Research Library at McGill University. [1929?] p.5.

${ }^{19}$ Ibid., p.6.

${ }^{20}$ Currie to Beatty, Nov. 17, 1926. RG2, C 59, McGill University Archives.

${ }^{21}$ Currie to Frederick P. Keppel. February 14, 1933. RG2. C69, McGill University Archives.

${ }^{22}$ Currie to Graves. May 13, 1931. RG2, C69, McGill University Archives.

${ }^{23}$ Currie to Frederick P. Keppel. February 14, 1933. RG2. C69, McGill University Archives.

${ }^{24}$ Currie to Beatty, RG2. C59, Nov. 17, 1926. McGill University Archives. ${ }^{25} \mathrm{Ibid}$.

${ }^{26}$ Currie to Beatty, Nov. 17, 1926. RG2, C59, McGill University Archives.

${ }^{27}$ McMurray, D. (1974). Four principals of McGill: A memoir 1929-1963. p. $16-17$.

${ }^{28}$ Currie to Gest,September 23, 1927. RG2, C69, McGill University Archives.

${ }^{29}$ Currie to Dr. Berthold Laufer, October 28th, 1929, McGill University Archives.

${ }^{30}$ Kiang to Currie, March 11, 1930. RG32, C735, File 4440. McGill University Archives.

${ }^{31}$ Part of the biographical information about Kiang Kang-hu is from "Biographical Sketch of Kiang Kang-hu," RG2, C59, McGill University Archives.

${ }^{32}$ Snow, Edgar. Red star over China. New York: Grove Press, 1968. p. 142.

${ }^{33}$ Website of Baidu: http://baike.baidu.com/view/477462.htm. Accessed December 17, 2011.

${ }^{34}$ Interview with Gest, June 20th, 1930. RG2, C69, File 1387, McGill University Archives.

35 “Department of Chinese Studies is Inaugurated." Annual Report 19311932. p.14.

${ }^{36}$ Department of Chinese Studies. RG2, C69, File 1387, McGill University Archives.

${ }^{37} \mathrm{Ibid}$.

${ }^{38}$ Ibid.

${ }^{39}$ Ibid.

${ }^{40}$ Ibid.

${ }^{41}$ Currie to Prince Amoradat Kridakara, August, 5, 1931, RG2, C69, File 1387, McGill University Archives.

${ }^{42}$ Currie to Secretary-General, the League of Nations, Geneva, October $27^{\text {th }}, 1932$. RG2, C69, McGill University Archives. 
${ }^{43}$ Ibid.

${ }^{44}$ Currie to Frederick P. Keppel. February 14, 1933. RG2. C69, 2207E, McGill University Archives.

${ }^{45}$ Daniel G. Dancocks, Sir Arthur Currie: a biography. (Toronto: Methuen, 1985), p. 279.

${ }^{46} \mathrm{Ibid}$.

${ }^{47}$ McMurray, D. (1974). Four principals of McGill: A memoir 1929-1963. Montreal: Graduates' Society of McGill University. p. 35.

48"Changes in Policy and Curriculum". McGill University Annual Reports of the Corporation, 1933-1934. p. 17.

${ }^{49}$ Governors' minutes re: Department of Chinese Studies. RG4, C19. McGill University Archives.
${ }^{50}$ Kiang to Bovey, November 1, 1934. RG4, C19. McGill University Archives.

${ }^{51}$ Frank Cyril James was the Principal and Vice-chancellor at McGill 1940-1962.

${ }^{52}$ Mrs. Kiang to James, RG2, C85. File 2164, McGill University Archives. ${ }^{53}$ James to Mrs. Kiang. RG2, C85, File 2164, McGill University Archives. ${ }^{54}$ James to Bovey. RG2, C85, File 2164, McGill University Archives.

${ }^{55}$ Bovey to James, RG2, C85, File 2164, McGill University Archives.

${ }^{56}$ Currie to Frederick P. Keppel. February 14, 1933. RG2, C69, File 2207E, McGill University Archives. 


\title{
J.W. McConnell and the Chancellorship of McGill University, 1942-3
}

\section{by William Fong}

\begin{abstract}
J.W. McConnell (1877-1963) was one of the most successful Canadian businessmen of his time, and possibly the richest man in Canada for much of his life. A promoter of stocks early in his career, he soon became a major industrialist and investor. He was president of St. Lawrence Sugar Refineries Limited for almost fifty years and publisher of the Montreal Daily Star and other newspapers for almost twentyfive. Among the companies of which he was a major shareholder were the International Nickel Company of Canada, Brazilian Traction, Montreal Tramways, Montreal Light, Heat and Power, Ogilvie Flour Mills, Canada Steamship Lines, and Borden. His reputation spread to Wall Street and the City of London, not only for his business acumen but also for his great generosity to medical and educational causes. He was one of the principal founders of the Montreal Neurological Institute. From 1909 to 1927, he was one of the most effective fundraisers in the country, for the YMCA, the war effort through Victory Loans, and the hospitals of Montreal. And for the remainder of his life he was the most generous contributor to good causes in Montreal if not in Canada as a whole.

With Lord Strathcona and Sir William Macdonald, he became one of the three greatest benefactors of McGill. After the death of Sir Edward Beatty, the Chancellor of the university, in 1943, McConnell was a natural candidate to succeed him. The board of governors, who were responsible for choosing a new Chancellor, were nearly all businessmen like him, and his assumption of the post would have been indeed in the tradition of James Ferrier, Strathcona, Macdonald and Beatty. But McConnell did not become Chancellor, and this is the story of why he did not. In abbreviated form, this was published in chapter 17 of the author's biography of McConnell in 2008. This article however presents considerably more detail.
\end{abstract}

\section{RESUMÉ}

J.W. McConnell (1877-1963) fut un des hommes d'affaires les plus prospères de son époque, et possiblement un des hommes les plus riches du Canada pour la plus grande partie de sa vie. Promoteur d'actions au début de sa carrière, il devint rapidement un industriel et un investisseur d'importance. Il fut président de la compagnie St. Lawrence Sugar Refineries Limited pendant presque cinquante ans, et éditeur du Montreal Daily Star et de divers autres journaux pendant presque vingt-cinq ans. Il fut un actionnaire important de plusieurs compagnies, notamment International Nickel Company of Canada, Brazilian Traction, Montreal Tramways, Montreal Light, Heat and Power, Ogilvie Flour Mills, Canada Steamship Lines, et Borden. Sa réputation se progagea jusqu'à Wall Street et Londres, non seulement pour sa perspicacité en affaires mais aussi pour sa grande générosité envers les bonnes causes dans les domaines de la medecine et de l'éducation. Il fut un des fondateurs principaux de l'Institut neurologique de Montréal. De 1909 à 1927, il fut un collecteur de fonds les plus efficaces au Canada, au profit de l'organisme YMCA, de l'effort de guerre par le biais du programme des Prêts de la victoire, et des hôpitaux montréalais. Il demeura pour le reste de sa vie un fort généreux contributeur aux bonnes causes à Montréal, sinon au Canada tout entier.

Avec Lord Strathcona et Sir William Macdonald, il devint une des trois plus grands bienfaiteurs de l'Université McGill. Après la mort de Sir Edward Beatty, le chancelier de l'Université, en 1942, McConnell fut un candidat tout désigné pour lui succéder. Les membres du Conseil des gouverneurs, qui avaient la responsabilité de choisir un nouveau chancelier, étaient presque tous des hommes d'affaire comme lui, et il aurait été dans la tradition de James Ferrier, Strathcona, Macdonald et Beatty que McConnell accède à ce poste. Toutefois, McConnell ne devint pas chancelier, et ceci est l'histoire qui raconte pourquoi il ne l'est pas devenu. Elle a été publiée sous la forme du chapitre 17 de la biographie de McConnell. Cet article, toutefois, présente considérablement plus de détails.

In some special sense we were a partnership in the development of McGill. I hope that some future historian of the University will realise that - for me personally - his death marks the end of an epoch and leaves me with a realisation that the world is emptier. 
$\mathrm{M}$ ost probably think of university chancellors as figures of prestige rather than power, if they think about them at all. This is particularly true of universities largely funded by taxes from provinces or states, as McGill has been since the 1950s. It was not true however of McGill in the 1940s, when most of its money came from private sources, and in particular business. McGill was often on the verge of insolvency and demanded business expertise not merely to survive but also to expand. Its Board of Governors had from its start been composed largely of men of business. They elected their own chairman who became by definition the Chancellor. By 1942-3, not all Chancellors had been businessmen but most had, and the increasing dependence of the University on corporate donations, as opposed to gifts from rich individuals, made it more important than before to have a Chancellor highly respected by the business community.

The outgoing Chancellor, Sir Edward Beatty, was certainly such, and he saw as his natural successor John Wilson McConnell (1877-1963), with whom he had long sat on the board of the Bank of Montreal and worked on various fundraising campaigns, in addition to the fact that McConnell had been an extremely effective fundraiser for McGill since 1911 and Governor of the University since 1928. McConnell was also the greatest individual benefactor to McGill from 1920 onwards and probably the richest man in Canada of his time, as well as internationally respected as a self-made man of extraordinary generosity, judgment and perspicacity. Despite all this, he did not become Chancellor, and this is an account of how and why.

Beatty-the president of the Canadian Pacific Railway since 1918 and Chancellor of McGill University since 1920had been ill with throat trouble and diabetes since December 1939, shortly after the outbreak of war in the previous September. In October 1940, the sinking by the Germans of the pride of the Canadian Pacific fleet, the RMS Empress of Britain, was another great blow to him. ${ }^{1}$ Nevertheless, he had just managed to perform one last service for the Empire in August. This was his arrangement with Lord Beaverbrook, the Minister of Supply in London, and J.W. McConnell and other businessmen in Montreal, for Canadian Pacific Air Services, a subsidiary of the CPR, to deliver desperately needed American-built bombers to Britain. They went from the officially neutral United States through Montreal under the auspices of the Atlantic Ferry Organization (ATFERO). In 1941, Prime Minister Winston Churchill created RAF Ferry Command to replace the nongovernmental ATFERO. Under Air Chief Marshal Sir Frederick Bowhill at the new airport at Dorval, Ferry Command was to report to Morris Wilson, president of the Royal Bank of Canada and a governor of McGill, but here in his wartime capacity as the representative in North America of the British Ministry of Aircraft Production. This transfer of responsibility to Ferry Command concluded Beatty's principal contribution to the war effort. In any case, in March 1941, he was largely paralysed with a stroke. He resigned the presidency of the CPR in 1942 but remained chairman of the company until his death in $1943 .^{2}$

With his stroke, Beatty lost his ability to speak and write. Although he recovered some of his powers in the following months, he became disabled with other illnesses and was confined to his house on Pine Avenue by 1942. Beatty had become a commanding, even an intimidating figure, with many enemies, and very unusually he had worked his way to the top as a litigation lawyer. As the head of the major corporation in the Dominion, Beatty was renowned for his effectiveness, directness and authority. $\mathrm{He}$ did not hesitate to summon the governors of McGill to meetings in the boardroom of his head office in Windsor Station rather than at their own boardroom at the University. During Beatty's Chancellorship moreover, two Principals of McGill (by definition also Vice-Chancellors) proved unable to serve a full term. It fell to the Chancellor to try to fill the consequent breaches in the continuity of administration, especially between 1933 and 1939 .

Beatty's interventions as de facto Acting Principal coloured the definition of the office of Chancellor from 1920 onwards. With the retirement of Sir William Peterson in 1919, Sir Auckland Geddes, then Minister of National Service in the United Kingdom, had been named Principal. But he never took office, and in 1920 he became instead the British Ambassador to the United States. Although in 1919 Frank Dawson Adams had become Acting Principal in the absence of Geddes, Sir Robert Borden suddenly resigned as Chancellor in 1920, after having served, in succession to Macdonald, for less than two years. McGill in 1920 was thus without leadership of the weight and the distinction that it had only very recently tried to secure.

Having become Chancellor of Queen's University in Kingston only in 1919, Beatty could hardly have coveted the additional duties of being Chancellor of McGill, but he did accept them in the following year. He resigned as Chancellor of Queen's only in 1923, to be succeeded there by the same Sir Robert Borden who had resigned as Chancellor of McGill. Also in 1920, Sir Arthur Currie, perhaps the ablest commander of Imperial forces of the Great War, became Principal and Vice-Chancellor of McGill. For 11 years, Currie seems to have been generally an effective and popular Principal even though dogged by slurs on his reputation as a general up to the armistice of 1918. Currie died in office in 1933. Then for two years, until 1935, McGill was unable to find a Principal to replace him, until William Massey Birks, a governor, proposed Arthur Eustache Morgan, since 1926 the Principal of University College, Hull, in England. Morgan seems to have been unknown to the other governors before his appointment, and in any case he immediately antagonized many, above all Beatty. Why McGill was unable to find a new Principal from 1933 to 1935, and then why it hired and then 
fired someone so undistinguished and unsuitable as Morgan, is obscure. In any case, not only had Beatty been largely in charge from the onset of Currie's illness in 1931: he had also personally sacked Morgan in 1937 and he was to resume control until the appointment of Lewis Douglas as Principal in 1938. Lewis lasted barely two years, resigning in 1939 because he felt it inappropriate to retain this position as an American citizen while Canada, but not the United States, was at war. Fortunately, the University was able to turn to its newly appointed director of the School of Commerce, F. Cyril James, to take over, but already, by 1942-3, James's tenure was coming into question.

McGill therefore had to find a new Chancellor as soon as possible, a man of unusual ability but possibly different from Beatty's. Had Arthur Purvis, the self-made businessman and highly regarded president of Canadian Industries Limited (affiliated with Imperial Chemical Industries of England) and already a governor, not been killed in an air accident in August 1940, he might well have been elected to succeed Beatty as both Chancellor and president of the CPR. He had served as chairman of the National Employment Commission in 1936-8 and in this capacity he had developed the reputation as a firm defender of the unemployed and an advocate of unemployment insurance. In 1940, he became Chairman of the Anglo-French Purchasing Commission in North America, but with the fall of France, he became the Director General of the British Supply Commission in North America, responsible for implementing the Lend-Lease Agreement to supply "surplus" American equipment to Britain for the war effort. Purvis was often described as brilliant and charming, especially in Washington, where his negotiations were crucial to the British war effort. In 1940, there was the rumour that he was to be ennobled as a viscount, but instead he was sworn of the British Privy Council, like a cabinet minister.

Although it is unknown precisely who among the McGill governors would have supported Purvis as Chancellor, he clearly stood before his death in some respects in contrast to Beatty, and thus he probably appealed to those yearning for a change of image for the University. In Washington in 1941, Purvis was winning over American officials as probably no Canadian or British representative before had done, and the Americans had now assumed the leadership of the Englishspeaking world. Purvis was also a tough businessman but with claims to being a humane and an enlightened one. Finally, he was also too busy abroad to be likely to interfere in McGill affairs in ways that critics were complaining of Beatty's Chancellorship.

Among the governors in 1942, one obvious successor, indeed the most obvious to Beatty himself, was J.W. McConnell, perhaps the richest and ablest businessman in the Dominion. He had been on the Board since 1928 and an energetic fundraiser for the University since 1911 as well as its most generous benefactor since the death in 1917 of Sir William Macdonald, the Chancellor since 1914. Beatty had carried out both his administrative and his ceremonial functions punctiliously, and there was nobody with the authority of his personality and his experience to replace him. The questions for the governors were first what they wanted the new Chancellor to do and secondly whether McConnell could fulfil the functions that they foresaw for the Chancellor.

Although possessed of enormous capacity for hard work and business success, $\mathrm{McC}$ Connell unlike Beatty shunned open confrontation and was widely respected for his kindness, tact and consideration. He was immensely distinguished in appearance and manner, but modest and almost shy to a fault and yet his devotion to McGill was unquestionable. He had been close to Currie and worked hard on fundraising for various causes with him and with Beatty himself. His attitude towards Morgan is unknown, but his closest friend on the Board was Birks, who had found and promoted Morgan and who indeed was the only governor to see Morgan off to return to England in 1937. McConnell had also been conspicuously supportive of Douglas, who was a seasoned man of business and had resigned as President Roosevelt's Director of the Bureau of the Budget over Roosevelt's decision to abandon the Gold Standard and to indulge in deficit spending. McConnell, finally, seems also to have been behind the hiring of James, who had been a financial historian at the University of Pennsylvania, as both head of the School of Commerce and then as Principal.

It has been suggested by the official McGill historian of its earlier years, Stanley Frost, to the writer that McConnell quietly coveted the Chancellorship. McConnell in fact seems to have desired no position whatever, except perhaps that of the owner of assets and companies. He hated speaking in public, and he often described himself as labouring under a certain sense of inferiority by not having obtained a university education. This admission was probably a reflection of genuine humility in the presence of academic achievement but it was not decisive in his reasoning. Like most of his fellow governors, he did not really believe, in any case, that a university degree was essential for a Chancellor. And so he came rapidly to support the banker Morris Wilson for the position, like McConnell himself another autodidact rather than a university graduate, but also like him an omnivorous reader. Notes for a eulogy, on Wilson's sudden death in May 1946, in McConnell's hand, suggest what McConnell most admired in him. They curiously reflect what others most admired in McConnell:

Always ready with sound advice, Morris was a true and consistent friend whose very presence radiated cheerfulness, goodwill and the spirit of compromise in any difficult situation, however hopeless the outlook might be. He had moreover captured that elusive thing called happiness which all men seek, but find only in selfless service for their less fortunate fellow men. In his long and tireless work for the 
Welfare Federation this quality of selflessness stood out above all others. To this humanitarian cause he gave of himself unstintingly to the great benefit of 32 charities embraced by the Federation. His home life was a happy one. He was a devoted and loving husband \& father, while his good works shall stand as a memorial to his name. His fine qualities of heart and soul remain as a living example to us all. To me his untimely passing is a grievous personal loss. ${ }^{3}$

Although apparently not desiring the Chancellorship, McConnell did seem to relish his role as a governor, and he faithfully attended every graduation ceremony at which he was able to be present, from the 1920s until well into the 1950s. His dedication to the university was unquestionable, as was his overwhelming generosity to it. It was therefore unavoidable for him to be considered as a most likely successor to Beatty. But his candidacy immediately met stiff opposition from several of his fellow governors. Their reasons are fairly but not completely clear, and in any case they evolved over time. In the end, two or three of his critics, in particular, prevailed to render his candidacy untenable, at least in the eyes of McConnell himself; and the record reveals that McConnell refused unconditionally two formal offers from the Board of the position.

In the aftermath of the debacle over his reluctant candidacy, it is also true that McConnell appears ruthlessly to have forced the ouster of his two most implacable foes from the Board. Thus he secured even greater authority among those who remained. He was effectively to nominate not only Beatty's successor, Wilson (1943-6); Wilson's successor, O.S. Tyndale (1946-52); Tyndale's successor, B.C. Gardner (1952-7); and finally probably Gardner's successor, McConnell's old friend, R.E. Powell (1957-64). McConnell died in 1963, but even Powell's successor as Chancellor, Howard Ross (196470), was a son of one of McConnell's closest colleagues in fundraising for the YMCA in 1909 and for McGill in 1911, J.W. Ross. The question of McConnell's failure to become Chancellor in 1943 discloses therefore something of the character of both McConnell and his fellow governors, and indeed of the tensions of St. James Street, then the business heart of Canada, where personal relationships were at times far frostier than they may have appeared to outsiders.

Although there was undoubtedly personal animosity to him involved, his opponents on the board couched their opposition in terms of their desire for reform of the office of the Chancellor after what they perceived as the highhandedness of Beatty, although they had themselves apparently backed Beatty in his brutal ouster of A.E. Morgan as Principal. In this yearning for a reform of the Chancellorship, they cannot be presumed to be devious or hypocritical, although the ostensible terms of their opposition to McConnell varied considerably. They probably did fervently believe that they were acting in the best interests of the University. It was however not until 1970 that the key principle for which they had declared they were fighting - the separation of the Chancellorship from the chairmanship of the Board of Governors - was adopted.

Since 1864, the President of the Royal Institution for the Advancement of Learning, in what became in 1867 the Province of Quebec, had been ex officio both Chancellor and Chairman of the Board of Governors of McGill. The Royal Institution dates from 1801, and it was originally established to operate two Royal Grammar Schools and District Public Schools, all established and funded by the Province and essentially nondenominational. McGill College (later University) was incorporated into it 1821 . Resistance by the Roman Catholic Church, however, led to a religiously divided system of public education in the Province and to local school boards. Thus a new Royal Charter in 1852 reduced the Royal Institution to running McGill alone and eventually such affiliates of McGill as Macdonald College, Royal Victoria College and the Montreal Neurological Institute. The trustees of the Royal Institution to this day comprise the governors of the University, and its President is still the Chancellor of the University. The Chancellor has remained naturally the ceremonial head of the University, so that the Principal is still called the Vice-Chancellor.

As Chairman of the Board of Governors before 1970 however, the Chancellor also oversaw the financial and administrative affairs. Many saw McConnell as one of the most influential men in St. James Street, if not the most influential; and there had already been much criticism from Frank Scott, of the faculty of law, as well as others, of the domination of the university by such alleged rapacious capitalists. Although they were in fact too varied as businessmen to fit Scott's characterization, there was disquiet even there that McConnell, with the reputation of the most aggressive capitalist of all, might adopt the same sense of entitlement to subservience from them that Beatty had evinced.

The call of some governors opposed to McConnell was therefore for a presumably relatively ineffectual "academic" as the new Chancellor, while some relatively younger man, probably a businessman, would chair the Board. It is not clear however what they meant by an academic. Their most obvious precedent for a Chancellor who was not chairman of a board of university governors was Charles Dunning. He was the non-chairing Chancellor of Queen's who also, unhappily for them, happened to be a distinguished businessman. He was indeed one of McConnell's closest colleagues as president of Ogilvie Flour Mills in succession, in 1940, to McConnell himself.

Dunning, a retired Premier of Saskatchewan and Dominion Minister of Finance, was at any rate himself without a university degree and certainly no academic in the sense of a university teacher. With the exception of Beatty, neither had any previous Chancellor of McGill been one, 
including Charles Dewey Day, Senator James Ferrier, Lord Strathcona, Macdonald and Borden. Moreover, the practice of Queen's University, in appointing a Chancellor without the power of chairman, had not deterred its appointment of the pugnacious Beatty himself in 1919. Nor did the opponents of McConnell find a formidable candidate. Their choice was Charles W. Colby, a highly respectable but littleknown historian with a Ph.D. who had been pursuing a distinctly non-academic career selling Remington noiseless typewriters, and whose suitability for the Chancellorship was openly deemed by Principal Cyril James and others as risible. Colby was 77 , plagued by indifferent health, uninterested in the position, and above all both a supporter and a great friend of McConnell's.

Who were McConnell's opponents on the Board? Two of them were cousins and partners in the accounting firm named after them, McDonald, Currie. George Cross McDonald (1883-1961) had been educated at the High School of Montreal and was a graduate in arts from McGill. His father had been John Macdonald, who - doing the reverse of Sir William Macdonald, formerly McDonald-later changed his name to McDonald, and he was described as a "proud, principled, fiery-tempered, stiff-necked man." This John McDonald (1840-1904) had become a founder of the Association of Accountants in Montreal in 1879 (and its first vice-president or president - the records vary-in 1897-8), and also the auditor of the Bank of Montreal and of many other businesses. ${ }^{5}$ As auditor, John McDonald called the distinguished vice-president (later president) of the Bank of Montreal, George (later Sir George) Drummond, "a rogue and a liar", and he later published verses describing the incident, of which he was perhaps inordinately proud. He is said to have threatened Drummond with a gun, so that Drummond was obliged go about with bodyguards. ${ }^{6}$

George McDonald developed a similar reputation for both probity and ferocity to that earned by his father. He first worked as a bookkeeper for the Anglo-Canadian Leather Company and then decided to become an accountant. This he did in 1909, after articling with the firm of Creak, Cushing \& Hodgson, which served as McConnell's firm for decades. A year later, he set up his own practice, sharing his office with Talbot Papineau, a descendant of the rebel Louis-Joseph Papineau, who was to fall in the Great War and whose cult as a good and loyal Canadian McDonald would perpetuate. McDonald was accustomed to difficult and important work. He helped to settle the estate of a great benefactor to McGill, John Thomas Molson, who had left $60 \%$ of Molson's Brewery to his son Herbert, and $40 \%$ to his nephew Fred, both of whom eventually sat on the McGill Board with both McConnell and McDonald himself. McDonald was also to train two of the Molsons in accountancy, John and Hartland, both of whom also became governors. In 1911, McDonald's cousin. George Selkirk Currie (born in 1889), joined him as his partner; and their firm grew steadily thereafter.
Soon after the start of the Great War, both McDonald and Currie joined the newly created Princess Patricia's Light Infantry regiment raised by Major (later Brigadier) Hamilton Gault. McDonald and Captain Percival Molson were in command of a company of reinforcements from McGill, and Currie was one of the four platoon commanders. George Creak and his firm took over their audits in their absence. Both McDonald and Currie won the Military Cross; and Currie won also the Distinguished Service Order, to be followed after the Second World War by the Companionship of the Order of St. Michael and St. George. ${ }^{8}$ McDonald had been severely wounded twice and was invalided, but Currie emerged as Deputy Assistant Quarter Master General of the $4^{\text {th }}$ Canadian Division. For the remainder of their lives, they were addressed as Major McDonald and Colonel Currie, taking as their new battlegrounds both St. James Street and McGill. If McConnell with his many directorships, until his retirement from most of them in 1937, occupied the summit of Canadian business, these two accountants were determined to remind him that he had enemies. Their careers illustrate how the McGill Board was for long an extension of St. James Street and its rivalries.

After the war, in 1919-20, McDonald investigated the bankruptcy of Thornton Davidson, the largest brokers on the Montreal Stock Exchange. These brokers were associated with the insolvent Merchants'Bank, being investigated byhiscousin Currie, which eventually had to be bailed out by the Bank of Montreal, following prosecution of its principals. McConnell had been associated with Thornton Davidson, the founder of the firm, until he went down with the Titanic in 1912, and even more closely with Sir Montagu Allan, when he was president of the Merchants' Bank. Notwithstanding the previous feud between John McDonald and George Drummond, George McDonald then followed in the precedent set by his father by becoming auditor to the Bank of Montreal, of which Sir George's son, Huntly Redpath Drummond, was president in 1939-42 and of which McConnell was long a director. So central had McDonald become to the Street that he was elected president of the Montreal Board of Trade in 1929, and chairman of the executive committee of the Canadian Chamber of Commerce in 1930-1. ${ }^{9}$ With the abandonment of the gold standard by the United Kingdom in 1931 and the consequent ruin of much of St. James Street, he administered the bankruptcy of the brokerage house of Greenshields. McConnell was simultaneously bailing out MacDougall and Cowans, ensuring its survival as the only insolvent firm to survive on St. James Street.

McDonald also developed an interest in politics. He advised Quebec on its response to the Rowell-Sirois Royal Commission on Dominion-Provincial fiscal relations, and he served on a royal commission on the relations between the Dominion and Saskatchewan and Alberta. He sat on the Quebec Electricity Commission (the Lapointe Commission) on the future of private utilities in 1934-5, and he taught 
part-time at the School of Commerce of McGill. In 1934, with Herbert Molson and Paul Sise, he conducted an audit of all of the finances of McGill.

Then his friend (and ten years later McConnell's) Maurice Duplessis came to power in Quebec in 1936. From 1937 to 1940 McDonald served as a member of the Quebec Taxation Revision Bureau, known as the Montpetit Commission. He developed a very close working relationship with Duplessis, and also with Mayor Camillien Houde, the Mayor of Montreal. Most significantly, in 1944 he became the first vice-chairman of the Quebec Hydro-Electric Commission, appointed by Premier Adélard Godbout and reconfirmed by Duplessis on his resumption of the premiership from 1944 until 1959. The purpose of Quebec Hydro, as it was popularly known, was to run the newly expropriated Montreal Light, Heat and Power Consolidated, which had exercised a largely effective monopoly over power on the Island of Montreal since 1901. McConnell had served as a director of this private utility from 1925 and had been a major investor in it for much longer, and he had fiercely opposed its nationalization by Godbout. It was McConnell's quickly made fortune, as chiefly earned from various private electrical utilities from 1909 onwards, in addition to his controversial take-over of St. Lawrence Sugar in 1912-15, that had inspired mistrust and envy of him on the Street.

The reasons for Currie's opposition to McConnell are less clear. He became prominent on the Board only after the failure of McConnell's candidacy, when he led the attack on the Principalship of James, McConnnell's ally. In 1940, he had become executive assistant to Col. J.L. Ralston, the Minister of National Defence, who had been a critic of McConnell's since McConnell's controversial takeover of the Halifax Electric Tramway in 1909. In 1941, Ralston appears to have been behind the vetoing of the appointment of McConnell as the Canadian Ambassador to Washington. In 1942, Currie rose to become Deputy Minister of National Defence (Army), but he was to return eventually to rejoin his accountancy partnership with McDonald. In summary, McDonald and Currie were at least as much part of St. James Street and the Canadian establishment as McConnell, and to all appearances men of the highest sense of public duty. $\mathrm{McD}$ onald's speeches reveal him to have been the soberest of men, incisive and selfless and possessed of vigorous and broad sympathies. But he seems also to have been, outside his speeches, unusually obstreperous and even violently quarrelsome, as can be seen presently, and it very much appears that his clash with McConnell was an issue of personality at least as much as of principle.

Certainly McDonald was a plotter, and evidence of his plotting abounds. McGill and especially its affiliated hospitals were well served by volunteers ambitious to make a name for themselves by doing good works, which sometimes led to seats on the Board. In March 1942, for example, Cyril James confided to his diary that John Newman ${ }^{10}$ was complaining to him that McDonald, with George Hogg and a Mr. Hutchison, ${ }^{11}$ was trying to oust Newman as president of the Montreal General Hospital. McDonald wanted to replace Newman with Matty Ogilvie, ${ }^{12}$ and then ultimately to instal a Mr. Elder ${ }^{13}$ as vice-president. But that very morning, Newman, James recorded, had also just "taken the skin off Ogilvie" himself; and Hogg also had had a "violent argument" with McDonald, and now Newman "intended to throw McDonald Currie from all the corporations with which he was associated." ${ }^{14} \mathrm{McD}$ onald felt Newman to be incompetent as president of the hospital, and was further outraged when Newman then took a seat on the McGill Board, although such a seat had traditionally been reserved for any president of the Montreal General.

McConnell had made the hospitals of Montreal, especially those affiliated with McGill, his special interest, and his service and generosity to them, especially as chairman of the Joint Hospital fundraising campaign of 1927 , had rendered his position on the McGill Board unassailable even by McDonald, not least because he had worked so hard on this campaign and subsequently for the hospitals with Col. Herbert Molson and with Beatty himself. Uniquely, McConnell was on the boards of the Royal Victoria and the Montreal General Hospitals, traditional rivals, as well as a principal founder with Sir Herbert Holt (long the president of Montreal Light, Heat and Power) of the Montreal Neurological Institute. He was a founder of the maternity wing of the Royal Victoria Hospital and for years the chairman of its annual charity ball, a major event in the Montreal social calendar. Combined with his vast experience of fundraising also for McGill itself, for Victory Loans during the Great War, and much else as well as the hospitals, his preparation for the Chancellorship was unimpeachable.

At the end of March 1942, with Beatty's health rapidly failing, Principal James finally approached McConnell about assuming the Chancellorship, confiding that Beatty agreed with him that McConnell was "the only appropriate person for the job". McConnell replied that he did not like making speeches, but James responded that Beatty had made few speeches and Sir William Macdonald none. McConnell was noncommittal, but James felt "reasonably certain that he would accept".15 James then went to McDonald, who claimed that he (McDonald), Col. Allan Magee, Walter Molson ${ }^{16}$, S.G. Blaylock, Ross Clarkson, G.W. Spinney and Senator Knatchbull-Hugessen and other governors would all oppose McConnell. McConnell, McDonald said, was "too overbearing" and McGill "definitely did not want another Chancellor who mixed himself up with administration". James denied that Beatty had ever done this "when there was anybody there to do it for him", but McDonald insisted that an "academic man" of "outstanding eminence" was needed, and he proposed C.W. Colby. ${ }^{17}$ Colby for James was insufficiently eminent and even ludicrous, and James insisted that McGill needed someone that was a household name in Canada, the 
United States and Great Britain, certainly not someone as absent from Montreal as Colby tended to be. McDonald retorted that all the Chancellor should do was to preside over Convocation, and leave the chairmanship of the governors to a junior businessman, as at Queen's. ${ }^{18}$

After James had discussed McDonald's position with Dr. W.W. Chipman, he recorded that he had never seen Chipman "so alarmed in my life." James was convinced that McDonald himself wanted to be both Principal and chairman of the Board while "Colby was now a dear old person whom nobody could object to in the least" could serve as Chancellor. Chipman went to see W.M. Birks and Huntly Drummond and he concluded that ten governors, of the total of 26, would support McConnell and seven would support McDonald. Gordon Pitts called for a campaign on behalf McConnell. ${ }^{20}$ Morris Wilson however, calculated the Board as evenly split about McConnell, with only four or five governors "violently opposed" to him. If there were in fact great enthusiasm for an academic Chancellor, Wilson would propose suggesting Chipman or Dr. Alfred Bazin to split the Colby vote. ${ }^{21}$

On the next day, McConnell himself told James that he had decided to decline the Chancellorship. James entreated him to reconsider as he, James, was "very eager" to have him, and all the members of the executive committee, apart from McDonald, wanted him. James suggested seeing first whether the Board preferred an academic Chancellor and then whether it contained a substantial recalcitrant minority. McConnell insisted that "he did not want anybody to think that he was standing round waiting for it", but also that he "would be very glad to have me keep his refusal up my sleeve to use as I wished to". If the University really needed him, he would take the position, "although his wife and family were strongly against it and he himself was by no means eager to take on further responsibilities."22

Then the executive and finance committee voted to add Fred Southam, ${ }^{23}$ Walter Molson and Bazin to its number to consider the Chancellorship. James pointed out to McDonald that Lewis Douglas, James's predecessor as Principal, and McDonald himself had approved altering the statutes to make the Chancellor in no sense academic, and the Principal as executive head and university administrator. In a private conversation after the meeting, McDonald insisted that "he had no quarrel at all" with James, but he complained that the old guard on the Board, particularly McConnell's friend Birks, had done nothing for years.

Paul Sise ${ }^{24}$ told James that he, Southam and Molson felt that Colby, presumably because he seemed so inoffensive, would be the best Chancellor for the next two or three years, following which they would accept McConnell. Sise noted that active campaigning by Birks and $\mathrm{McD}$ Donald, respectively for and against McConnell, had "very nearly produced bitter dissension" on the Board. James replied that the real contribution that a Chancellor could make over the next five or ten years was to "bring the University money enough to enable us to achieve our ideals". McConnell could do this and was also persona grata with the provincial government and well known outside Canada, whereas Colby might be thought a "joke".25

By June of the following year, 1943, Beatty having finally died in March, the question of the Chancellorship was both more urgent than ever and still awaiting solution. Southam had declared himself to James in favour of McConnell, and Deans Brittain, Mesurier and Macmillan had expressed themselves very worried by the prospect of Colby. Colby said to James that - at 77-he felt himself too old for the position, and that he himself supported McConnell and that G.W. Spinney should take the Chancellorship if the opposition to McConnell proved too great. ${ }^{26}$ But then McConnell declared that he had, upon reconsideration, decided definitely not to accept and that he would prefer instead the presidency of the Royal Victoria Hospital, which would be less onerous. James reminded McConnell that Beatty had been holding both this particular presidency and the Chancellorship simultaneously, and he said that McConnell's own preference for the Chancellorship, Morris Wilson, was not yet ready. ${ }^{27}$

On June 30, 1943 the fourth meeting of the special committee on the Chancellorship was held at the Mount Royal Club. The written nominations were counted. Colby was the first choice of five, and suggested by two others, for a total of seven. McConnell was the first choice of 12 and suggested by three others, for a total of 15 . Wilson was the first choice of one, and suggested by eight others, for a total of nine. Spinney was suggested by four. The others suggested were W.M. Birks, Dr. W.W. Chipman, Dr. C.F. Martin, A.B. Wood, Walter Molson, S.G. Blaylock, ${ }^{28}$ Huntly Drummond, Chief Justice Sir Lyman Duff, Prime Minister Mackenzie King, and Mr. Justice W.L. Bond. Colby wrote to urge McConnell as Chancellor or, failing him, Drummond, Wilson or Spinney. The committee - Bazin, Birks, Chipman, Southam and Spinney, with James in the chair, and all of them friends of McConnell-unanimously decided on McConnell. McDonald, who was away on a fishing trip, later complained bitterly that they had changed the rules for making a decision. Nevertheless, the committee still found that of the other governors the following remained opposed to McConnell: Ross Clarkson, ${ }^{29}$ Huntly Drummond, George McDonald, Hugh Crombie, ${ }^{30}$ S.G. Blaylock and Senator Adrian Knatchbull-Hugessen. ${ }^{31}$ Given McConnell's expressed reluctance, the committee felt strongly that unanimity, or near unanimity, was necessary before approaching him again.

Through July, James himself lobbied for McConnell's candidacy, and in the end he found only McDonald and Hugessen absolutely opposed. Hugessen declared that he thought that McGill would be making "a serious mistake, that it was selling its birthright for a mess of pottage" in considering McConnell. Molson, hitherto in league with McDonald, said that he was willing to vote for McConnell 
after the withdrawal of Colby.32 On the morning of July 13, the crisis came to a head with two meetings of the special committee and the visit of a delegation (James, Chipman, Wilson and Wood) to McConnell. McConnell had reiterated his refusal, but James still felt that he would accept a formal invitation from the majority of the governors. McDonald, James found, was "damnably eager to postpone the whole business for three months", and Southam was willing to agree. $\mathrm{McD}$ onald offered to resign from the special committee if the others insisted on unanimity but he was urged to reconsider.

W.M. Birks had obtained McConnell's agreement to accept the Chancellorship only six weeks before, in a private conversation. His letter to James on July 13 after hearing the news captures his indignation:

I cannot but feel that your Committee in striving to please an over-critical small minority (some of whom won't play unless they get their way) has been unwise and with tragic results.

Academic snobbery has lost to McGill the best man in Canada, and somebody bears a heavy responsibility; for his genuine interest (direct and indirect) would have meant many millions.

They quote Sir William Mulock as Chancellor at Toronto, but Varsity is supported by the Ontario Government. If McGill could live on the Quebec Government, appoint my friend, Chief Justice Bond, and confine the Governors to academicians and "let George [McDonald?] thumb his nose at 'St. James Street."

Charlie Dunning, Chancellor of Queen's, never even saw the inside of a high school!

From James McGill, Redpath, Molson, Strathcona and Macdonald onward, McGill must depend on financial Montreal,- - first our fur traders and railway kings, then our bankers and merchant princes of the English-speaking minority, and none of them graduates.

When I joined this financial board 33 years ago, it was smaller, but we had (1911/12) 12 financial (non-grads) to four graduates, and 30 years later ('42) the former had sunk to 7 and the latter risen to 15.33 In my humble opinion this proportion should be reversed.

There has been steady pressure ever since to appoint graduates, but I did not think that I would live to hear two members say openly, "only academicians" and scorn "St. James St."

The Board is rapidly shaping so that no mere financial man would feel comfortable upon it, in which case we have damned McGill."34
On the following day, the governors continued to do battle. Wilson wanted to send another delegation to McConnell, but Chipman and Wood declared that he would not change his mind. Hugessen and McDonald repeated their adamant opposition, and $\mathrm{McD}$ Donald added that he would rather have Samuel Bronfman as Chancellor for 10 years than McConnell for five years. ${ }^{35}$ Southam and Wilson proposed a delay of three months, which was carried. James felt very bitter that he had failed to tackle McDonald to get "rid" of him "for good", but also that McConnell's continued expressions of refusal had undermined him. Even Birks, one of McConnell's closest friends, wrote to James that he (Birks) was on record as favouring a Lord Rector, as at the Scottish universities, a non-resident world figure, for McGill, such as the provincial University of Toronto could not have. He also commented on three of the opponents of McConnell, combined with the lack of disdain held by at least two of them for his money:

Colonel Magee (whom I so admire) wishes to appoint such a figure [as a Lord Rector] as Chancellor, but would not object to McConnell doing the work, give or secure the cash, but deny him the honour,-very nice, but it won't work!

Senator Hugessen also wishes a big academic figure as in England and Toronto, where the Government finances the Universities. McGill is not in England or Ontario.

McDonald insists on calling the tune - also with condescension will permit McConnell to pay the piper - nice, but it won't work ${ }^{36}$

In the end, it seems that McConnell's candidacy failed for various reasons. Chief among them was that McConnell genuinely did not want the position much, if at all. He had long been probably the richest man in Canada and retired from nearly all of his many boards, except at McGill, in 1937, and he was not in the least interested in honours or in honorary positions. By now Southam, a close friend, said that McConnell was "not a strong man", presumably physically. Under pressure from his wife Lil, who was concerned about his health, McConnell had already declined the offer of a seat in the Dominion cabinet in 1940. He also remained a very busy man; and when he told James that he would prefer the presidency of the Royal Victoria Hospital, he alluded to the fact that that position would require only sporadic bouts of activity to raise money for new buildings. In any case, as subsequent events would reveal, he was perfectly happy, without the Chancellorship, to continue to contribute financially to the University, and even more to raise money for it in 1943. Thus speculation about his motivation even by some of his friends, that he was secretly yearning for the Chancellorship in return for his benefactions, was to be abundantly proved as wrong.

The most interesting question is why McDonald was so opposed to him. His opposition probably dated back to 
McConnell's bitter and brilliant takeover of what became the Montreal Tramways franchise in 1909-12, and the subsequent battles over transit, and then a related electricalpower franchise that raged in Quebec up to 1925. Many had concluded at the time that McConnell was dishonest, especially in his financing of this takeover, just as he had been previously widely accused of dishonesty in his takeover of St. Lawrence Sugar in 1912-5. ${ }^{37}$ Montreal Tramways was run by a provincially appointed commission from 1915 onwards although it remained a privately owned company. In 1925, the electrical interests financed by McConnell and others in 1909-12 were taken over by their competitors, Montreal Light, Heat and Power and Shawinigan Water and Power, who ran a virtual duopoly over the supply of power to much of the province. McConnell joined the board of Montreal Light, Heat and Power and became a major shareholder of it and ally of its president since 1901, Sir Herbert Holt, another governor of McGill, who however died in 1941. Long before McDonald was sitting on the Lapointe commission on the future of the privately owned power utilities of Quebec in 1934-5, Montreal Light, Heat and Power had become the most hated monopoly - and symbol of English-speaking domination of the economy - that Quebec nationalists were determined to expropriate. But the Lapointe commission had concluded that the province could not afford to buy out the shareholders of any of the privately owned utilities in the province.

In the ten years that followed, a consensus emerged in the province that the requisite funds could be found, determined by a commission to estimate the fair value of the shares, at least of Montreal Light, Heat and Power, with Shawinigan Water and Power not to be expropriated until almost 20 years later. McConnell bitterly fought what he saw as the undervaluation of his shares in Montreal, Light, Heat and Power, but the expropriation of the company proceeded under Premier Godbout in 1944. And even after Duplessis had resumed power in the same year he did nothing to reverse this expropriation. Ever the rebel, even against St. James Street, McDonald, - as already mentioned-became one of the first members of the Quebec Hydro-Electric Commission, which took over the assets of Montreal Light, Heat and Power. This was only months after the struggle over the Chancellorship of McGill had concluded. Quebec Hydro, as the Commission became better known, was the antithesis of what McConnell had fought against for most of his life, namely State as opposed to free enterprise. Although $\mathrm{McD}$ onald never mentioned the battle over Montreal Light, Heat and Power, in the context of McConnell's candidacy for the Chancellorship, this battle probably decisively coloured the unyielding hostility between the two men, and by extension between McConnell and McDonald's cousin Currie.

The opposition of Hugessen is even more intriguing. $\mathrm{He}$ was a younger son of Lord Brabourne and the son-in-law of G.H. Duggan, who had presumably been close to McConnell on the board of Dominion Bridge. He was also the senior partner of the law firm that Peter Laing, McConnell's sonin-law, was to join in 1944. The only Old Etonian in the Canadian Senate, Hugessen was particularly proud of his own noble birth, and it appears that he found McConnell overbearing for someone of such relatively humble birth. Apart from McDonald, Currie and Hugessen, none of the governors remained opposed to $\mathrm{McC}$ connell to the end, but McConnell still declined the Chancellorship, to the dismay of James.

For a while after McConnell had withdrawn however, a threat remained on the board. Frustrated in his efforts to reduce the role of the Chancellor, McDonald then openly turned against Principal James, who had been quietly fighting for McConnell as Chancellor all along, and he lobbied the governors for James's ouster. Dorothy McMurray, who had faithfully served as secretary to Principals Currie, Morgan, Douglas and James, had seen the spitefulness and destructiveness in McDonald's character over the decades. She urged James to carry on.

McDonald found little support for his campaign against James, and he resigned from the Board in considerable bitterness. Then McDonald's cousin and partner George Currie took up the campaign against James. McConnell supported James throughout Currie's campaign against him, to the point of supplementing James's salary when it appeared that the Principal might be leaving for the presidency of the University of Pennsylvania. At the crucial meeting of the governors to confirm James as Principal, McConnell made a resounding speech, and a very curious one. He attributed to James every success of the University, for which McConnell himself was actually responsible. It could hardly have been lost on the governors that McConnell was actually reminding them of what the University, and indeed James himself, owed to him. Whether he was also hinting at his own resignation if James were to go is not so clear. But it seems fair to conclude that he did not want to work with any other Principal, and as usual his will prevailed. McConnell boxed in Currie, who found himself forced to resign in defeat.

McConnell himself alluded to the resignations of the two cousins, McDonald and Currie, in a letter to James many years later:

I shall not soon forget the merry fight in a certain quarter with respect to the election of the late Morris Wilson as Chancellor [instead of McConnell], and the most disagreeable and spiteful speech delivered against you, resulting in a resignation [by G.C. $\mathrm{McD}$ onald]. Nor the event later on where an inside man [G.S. Currie] made the unbelievable declaration that $50 \%$ of the Governors would like to see you go.

At your request, and upon your withdrawal from the meeting, I took the Chair and poled [sic] the Board one by one so that each member would express his 


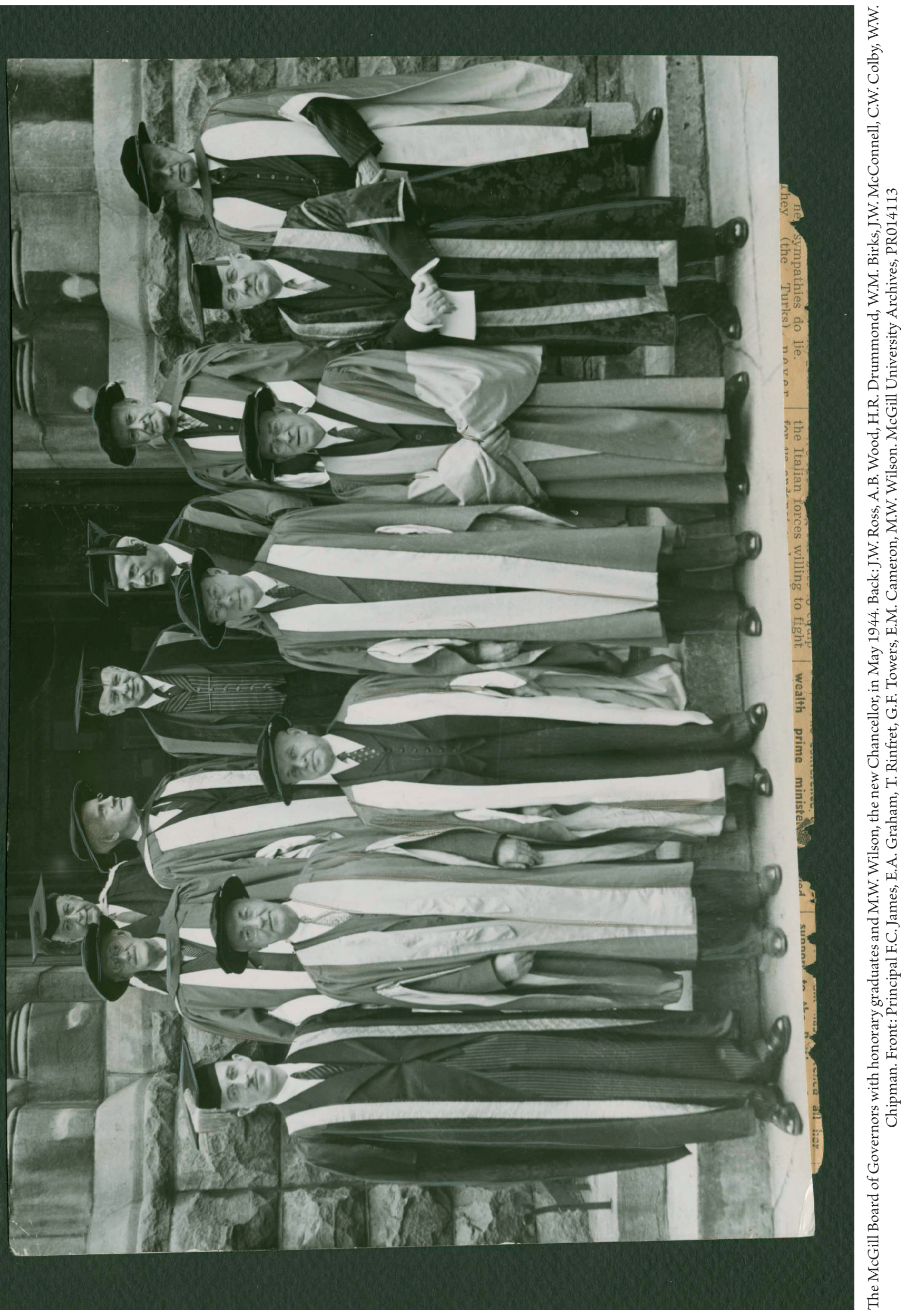


views on the subject without persuasion, which resulted in $100 \%$ vote of confidence for you. I have no reason to believe that any of them have since changed their minds. ${ }^{38}$

In an apparent reference to Currie, McConnell also remarked in a footnote to this letter: "This resulted in another resignation, though a bit slow in coming. Loyalty cannot be bought at a price - but where it exists, it is well worth rewarding". He and James remained loyal to each other, and though they had their differences, some very serious, they together were to steer McGill through some of its most trying years.

McConnell let no alleged hard feelings over the issue of his candidacy for the Chancellorship detract from his commitment to McGill, even for a day. Throughout the many months through which the governors were debating his candidacy, he continued to work closely with James on acquiring new properties for the University and on preparing them for new uses. After the question of the Chancellorship had been settled, he maintained the same pace. He found inspiration in, and he felt humbled by, the selflessness and the sacrifices of those fighting the war. They seemed to confirm what had been his long-held view of salvation was to be found through faith or through works or through some combination of them. He saw his own work on the home front as minor in comparison with that of those in battle. But each was still obliged to do his or her part. As he put it to his relatives in California, the Wasserboehrs, at the end of 1942:

The story of this life and death struggle with U-boats, floating mines and Nazi raiders will perhaps never be told. Apart from the miraculous defence of Great Britain where the R.A.F. smashed the much vaunted Nazi Air Force, the story of sea mastery by British and Canadian Navies, and the great Merchant Marine, is beyond the powers of comprehension. It is the most incredible story of heroism and achievement the world has ever known.

To me, Hitler is the personification of Satan at work on earth, bringing trials and suffering worse than death to innocent people wherever his evil hand is felt. Our fight is surely a righteous crusade against the powers of darkness. "By their works ye shall know them." Faith without works is dead. ${ }^{39}$

While ultimately declining the Chancellorship, McConnell agreed with Birks that McGill still could not survive without strong support from St. James Street, as even with such support the University was only barely viable. There was moreover no prospect of the level of government support for McGill comparable to that enjoyed by the University of Toronto, a problem that McConnell himself would address several years later. Since 1909, McConnell had been deeply concerned about the solvency of McGill, and he now realized that heavy taxation had made the university more reliant on corporate donations than on those from rich individuals such as himself. He therefore successfully proposed his old friend Morris Wilson, the president of the Royal Bank of Canada, and also not a graduate, as the next Chancellor. ${ }^{40}$ Wilson may have been his choice all along.

Moreover, $\mathrm{McC}$ Connell himself was to remain the kingmaker of the next two, or perhaps even more, Chancellors, and the power behind their throne. ${ }^{41}$ His power derived from his continued generosity to the university, which actually increased after his refusal of the Chancellorship, and he became more active than ever in rescuing it from various crises, the first emerging in the very same year. Single-handed, he went to corporations all over the city and the country and solicited crucial donations from them that were to keep the university afloat for years to come.

The failure of McConnell to be elected Chancellor seems to demonstrate that he was not the undisputed leader of either St. James Street or the governors, not merely up to Beatty's death in 1943 but also afterwards. McDonald himself was a St. James Street accountant, despite his barbs about McConnell and the Street, and even after his resignation and Currie's, Hugessen, himself a St. James Street lawyer, remained on the Board. For all its apparent homogeneity in representing St. James Street, the Board did not in private speak with one voice. It was by the 1940 s already reflecting an effort to create a new place for the university in an increasingly nationalistic province, McDonald worked hard with Premiers Duplessis and Godbout, and McConnell himself had supported Godbout over Duplessis because of Duplessis' opposition to the war effort. When later, from 1946 to about 1956, McConnell himself cultivated Duplessis to ensure provincial funding for McGill he was widely accused of being in collusion with the Premier for private gain. This accusation does not stand up under examination, and in fact the liaison between the two men was Judge Thomas Tremblay, the chairman of a provincial royal commission on relations with the Dominion, whose report foreshadowed much of the "Quiet Revolution" that was to follow in the sixties. Duplessis preferred to describe himself as a Quebec autonomist rather than nationalist, but it was he that instituted the provincial flag, in 1948, that was to become the most potent symbol of Quebec nationalism. Tremblay moreover was also chairman of the commission to evaluate the shares of Montreal Tramways, prior to its expropriation in 1949, thus bringing to a close the private ownership of this utility organized by McConnell in 190912. McConnell was thus above all resolutely pragmatic, to the point of assiduously courting those to whom he might have been thought least sympathetic, but always with the goal of ensuring the welfare of McGill.

When the question of the Chancellorship had been settled in 1943, McConnell was named the first "Senior Governor". In this position, he happily played a relatively discreet and yet tirelessly helpful role for McGill as a whole for almost two more decades. He was content indeed quietly to wield 
seldom-questioned influence over the Board thereafter, but never to wield it for his self-aggrandizement. From 1943, almost to his death 20 years later, McConnell was - despite such enemies as Frank Scott - the most constructive force, and the ultimate arbiter, for McGill. As such, he was a worthy successor to Sir Edward Beatty, but unencumbered by the ceremonial burdens of the Chancellorship. By the end of the twentieth century, he had still been the only senior governor, and then governor emeritus, of the University, a fact that testifies to the uniqueness of his role.

Notwithstanding his failure to become Chancellor, McConnell ascended in importance at McGill from 1943 onwards, not because he commanded the undivided allegiance of the Board, but because he generally commanded the undivided allegiance of James. Theirs was a curious alliance, and there is no real warmth in the extensive surviving correspondence between the two men. They were however complementary in their skills and united by their devotion to the University.James, though a hard and conscientious worker and a professor of finance, and perhaps a great Principal, had no gift for fundraising. McConnell of course had this gift in abundance, but within the academic community he was no consensus-builder, which James was. They also possessed a shared vision for the University, as an internationally known centre particularly in the sciences and medicine, despite their falling-out over the question of federal funding for it. James was probably the more profound thinker of the two, and a man of broader sympathies, although not necessarily by far.

In any case, on the essential role of McGill James fundamentally agreed with McConnell. This role had been evolving since 1918 and it was one that the Board was generally to subscribe to for the next four decades. Although seldom explicitly articulated in words, it became clear in the hiring policy of the University, with an emphasis on men of international reputation, such as Wilder Penfield. As McGill was not a provincial university like the University of Toronto it felt little obligation to depend largely on local talent. In any case, most Quebec academics and researchers would probably be drawn to the French-speaking universities of the province, and so McGill had little choice but to draw upon its connections in the British Empire and in English-speaking North America in particular. In so doing, it was likely to enhance higher education in the province more generally, and to assert effectively the crucial part that English Montreal had to play in the educational and more broadly cultural development of Quebec. That it was not a fanciful vision is proved by the fact that, even at the start of the twentieth-first century McGill remains probably the best-known Canadian university abroad, notwithstanding the relatively greater wealth and size of the University of Toronto. At every stage and in every way McConnell was at the heart of the unfolding of this vision in tangible form.

\section{ENDNOTES}

Some of the research for this article was used in the writing of chapter 17 of William Fong, J.W. McConnell: Financier, Philanthropist, Patriot (Montreal, Kingston, London and Ithaca: McGill-Queen's University Press, 2008). Since the research on which this article is based was done, most of the McConnell Papers used and many others have been deposited at the McGill University Archives (MUA) as the J.W. McConnell Fonds, MG 4240. The other chief primary sources in these Archives, used for this article, are the papers of Principal F. Cyril James and the Minutes of the Board of Governors.

${ }^{1}$ This same liner had transported the McConnells and two of their children to India in 1936.

${ }^{2}$ Sir Edward Wentworth Beatty (1877-1943) was only a few months younger than McConnell. He attended Upper Canada College and the University of Toronto. In 1901, he joined the CPR as general counsel, and he spent his entire career with it. He was created a Knight Grand Cross of the Order of the British Empire in 1935.The only biography of Beatty is D.R. Miller-Barstow, Beatty and the C.P.R. (Toronto: McClelland and Stewart Limited, 1951). For this article, copies of his outgoing letters, in the archives of the CPR while in Montreal, have been consulted.

${ }^{3}$ McConnell Papers, undated notes, but undoubtedly from 1946 when Wilson died. McConnell was one of his honorary pallbearers at Wilson's funeral at St. James United Church. His eulogy, slightly altered, is reproduced on p. 20 of an "In Memoriam" booklet, a special issue of the Royal Bank Magazine, published after the funeral, a copy of which is also in the McConnell Papers.

${ }^{4}$ Campbell W. Leach, Coopers \& Lybrand in Canada: a chronicle of the McDonald, Currie years 1910-1973 (privately printed by Coopers \& Lybrand, 1976), p. 3 of the prologue. Mr. Warren Chippindale has kindly provided copies of certain of McDonald's addresses, with the assistance of Coopers \& Lybrand).

${ }^{5}$ It received its provincial charter in 1880 . The association was the first formal accountancy organization in North America, preceded only by those in Edinburgh (1854), Glasgow (1855), and Aberdeen (1867), and practically incorporated simultaneously with the Institute of Chartered Accountants in England and Wales (1880). It preceded the American Society of Public Accountants by seven years. The Dominion Association of Chartered Accountants began in 1910, promoted by A.F. Riddell and J.W. Ross, also of Montreal. The preeminence of the Montreal Association suggests the significance of both Scotsmen and accountants in Montreal at the time. Among the 13 chartered accountants of the Association was Philip S. Ross, whose firm (P.S. Ross \& Sons, founded in 1858) later became part of Touche, Ross \& Co. J.W. and J.G. Ross, also accountants and closely connected to McConnell, were of the same family. In 1927, the Association became the Society of Chartered Accountants of the Province of Quebec. By the 1940s, there were more than six separate organizations of accountants in Quebec, however. In 1946, the provincial legislature changed the name of the Society to the Institute of Chartered Accountants of Quebec and gave it the exclusive right to license Chartered Accountants. The Institute absorbed the other accountancy organizations. (See Edgar Andrew Collard, First in North America, One Hundred Years in the Life of the Ordre des Comptables Agréés du Québec (Montreal: privately printed, 1980) and George C. McDonald, "The Development of Accountancy in Montreal and a History of the Firm" (Magog: unpublished typescript, 1946).).

${ }^{6}$ Coopers $\mathcal{E}$ Lybrand in Canada, p. 2. The story of the gun is part of the tradition of the Drummond family. The violent reputation of Montreal business life persisted at least into the 1930s, when Sir Herbert Holt is said to have needed four armed guards to surround him as he walked from his house on Stanley Street to the Power Building on Craig Street. Holt is also said to have been shot in his bath, by the broker W.E. Luther in about 1933, who later fatally shot himself while not realizing that Holt was going to survive.

${ }^{7}$ Major Talbot Papineau, MC, of Princess Patricia's Light Infantry, killed at Passchendaele in 1917, grandson of Louis-Joseph Papineau and cousin of Henri Bourassa, friend of Alfred Baumgarten and became a model heroic French Canadian among English Montrealers after the First World War, and was invoked by McDonald during the conscription crisis of the Second: 
see his "Leadership for a United Canada: The Position of the Province of Quebec, the Effect of the Political System on our Confederation and the War Effort of Canada" (unpublished typescript, 18 November 1942). McConnell shared fully McDonald's dismay at the fact that more nonFrench soldiers than French ones had enlisted even from Quebec alone by May 1942.

${ }^{8}$ The firm seems to have favoured decorated ex-servicemen. Among the partners it admitted in 1924 were two other holders of the Military Cross, Kenneth Blackader of the Black Watch (later a Brigadier, CBE and DSO) and J.A. de Lalanne (later Brigadier, CBE, Vice-Adjutant General of the Department of National Defence (Army) and Mayor of Westmount).

${ }^{9} \mathrm{On}$ his subsequent appointment as president of the Canadian Chamber of Commerce, the Winnipeg Tribune (15 September 1937) described him as "Canadian, done in granite" and "a ruthless critic of incompetence and crookedness, governmental or private".

${ }^{10}$ Born in Montreal in 1878, Newman had been president of General Steel Wares Limited since 1927 and of other companies, and he was a director of the Canadian Bank of Commerce, Baldwins Limited of England, the Montreal Trust Company, the Sherwin-Williams Company of Canada Limited, the Carter-White Lead Company of Canada Limited, Canadian Car and Foundry Limited, Price Brothers Company Limited, the Hamilton Bridge Company Limited, and the Anglo-Canadian Telephone Company. He was president of the Montreal General Hospital and of the Verdun Protestant Hospital for the Insane, and a director of the Boys' Farm and Training School as well as a governor of McGill.

${ }^{11}$ Col. Paul Phelps Hutchison, ED, KC, LLD, DCL of Heward, Holden, Hutchison, Cliff, McMaster \& Meighen.

${ }^{12}$ Lt.-Col. William Watson Ogilvie, grandson of W.W. of Ogilvie Flour Mills, who eventually did become president of the Montreal General.

${ }^{13}$ Aubrey Huntingdon Elder, KC, of Wainwright, Elder \& McDougall, born in Huntingdon, Quebec, in 1889, president of the National Drug and Chemical Company of Canada Ltd., and a director of the Prudential Insurance Company of America, the Miner Rubber Co. Ltd., James B. Stetson (Canada), Ltd., the Amalgamated Electric Corporation Ltd., the Canadian Bronze Co. Ltd., and the Guarantee Company of North America.

${ }^{14}$ MUA, MG1017, C49, James diary files, 3 March 1942.

${ }^{15}$ MUA, MG1017, C49, James diary files, 30 March 1942.

${ }^{16}$ Born in 1883, son of John Thomas Molson, Walter Molson established Molson, Lobley \& Co. Ltd., real-estate, insurance and financial agents in 1911, and was a director of the Montreal District and Savings, Bank, the Dominion Oilcloth and Linoleum com. Ltd., Remington Rand. Ltd. (Canada), the National Trust Company, the Lake of the Woods Milling Co. Ltd., the Dominion Glass Co. Ltd., the Reliance Insurance Company of Canada, Goulds Pump Inc., the Standard Life Assurance Company and other companies. He had been president of the Canadian Club of Montreal and of the Montreal Board of Trade.

${ }^{17}$ Charles W. Colby, PhD, DCL, LLD, born in Stanstead, Quebec, in 1867, and educated at Stanstead College, McGill and Harvard, was a director of the Canadian Bank of Commerce, Moore Corporation Limited, the Dominion Wire Rope and Cable Co., the F.N. Burt Co., the American Sales Book Co., and the Pacific Manifolding Co., and vice-president of Asbestos Corporation Ltd. and the Goulds Pump Co., as well as chairman of the Remington Rand Co. With strong Methodist antecedents, he was a friend of McConnell's.

${ }^{18}$ MUA, MG1017, C49, James diary files, 2 April 1942.

${ }^{19}$ Walter William Chipman BA (Acadia), MB, MD (Edinburgh) (18661950), born in Wolfville, Nova Scotia, became professor of gynaecology at McGill in 1910. In 1926-9, he was the first director of the Women's Pavilion of the Royal Victoria Hospital. He was a governor of McGill from 1932 to 1947.

${ }^{20}$ MUA, MG1017, C49, James diary file, 1 and 2 April 1942.

${ }^{21}$ MUA, MG1017, C49, James diary file, 10 May 1942. Alfred Turner Bazin, DSO, MD, CM, born in Montreal in 1872, and educated at McGill, had been Lieutenant-Colonel in the $3^{\text {rd }}$ Canadian General Hospital in the Great War and was now a surgeon in private practice. His wife was a sister of Milton Hersey, a close colleague of McConnell's at St. Lawrence Sugar and elsewhere.

${ }^{22}$ MUA, MG1017, C49, James diary file, 11 May 1942.

${ }^{23}$ Southam, a member of the newspaper-publishing family, and president of Southam Printing in Montreal, was a close friend of McConnell's, while Molson seems to have shared the reserve of his family generally towards McConnell but was not openly hostile.

${ }^{24}$ Paul F. Sise, BSc, born in 1879, a son of C.F. Sise, the founder of The Bell Telephone Company of Canada (1834-1918), and son-in-law of Charles E.L. Porteous. Educated at McGill, had been president of the Northern Electric Company since 1919, in succession to his brother, E.F. Sise. He was also president of Canadian Associated Aircraft Ltd., and a director of the Royal Bank of Canada, the Bell Telephone Company of Canada, the Montreal Trust Company, the Lake of the Woods Milling Company, the Dominion Engineering Company, the Industrial Acceptance Corporation, the Amalgamated Electric Corporation, Belding-Corticelli Ltd., the Sherwin-Williams Company of Canada Limited, Price Brothers Ltd., the Shawinigan Water and Power Co., and the Dominion Bridge Co.

${ }^{25}$ MUA, MG1017, C49, James diary file, 14 May 1942.

${ }^{26}$ George Wilbur Spinney, born in Yarmouth, Nova Scotia, in 1889, was now general manager of the Bank of Montreal and a friend of McConnell's, as well as a governor. He succeeded H.R. Drummond as president of the Bank in 1942-8.

${ }^{27}$ MUA, MG1017, C49, James diary file, 7, 17 and 22 June, 1943.

${ }^{28}$ Selwyn Gwillym Blaylock, BSc, LLD, born in Paspebiac, Quebec, in 1879, was president and managing director of the Consolidated Mining and Smelting Company of Canada Limited in Trail, British Columbia, and a governor.

${ }^{29}$ Ross Clarkson, born in Port Hope, Ontario, in 1888, was assistant general manager of the Royal Trust Company, where he had worked since 1908. In 1955 he was to become chairman. He was a director of the British American Bank Note Co, Ltd., the Sun Life Assurance Company, Montreal, London, and General Investors Ltd., Dominion Oilcloth and Linoleum Co. Ltd., Dominion Wire Rope Ltd., the Industrial Acceptance Corporation Ltd., the Consumers Glass Co. Ltd., the Lake of the Woods Milling Co. Ltd., the Dominion Textile Co. Ltd., the Great Lakes Paper Co. Ltd., and chairman of the Canadian advisory committee of the Northern Assurance Co. Ltd.

${ }^{30}$ Hugh Arthur Crombie, BSc, born in Saginaw, Michigan in 1896, educated at McGill, vice-president of the Dominion Engineering Works Ltd., a director of the Dominion Textile Co. Ltd. and Montreal Cottons Ltd., governor of McGill, 1941-4.

${ }^{31}$ The Hon. Adrian Norton Knatchbull-Hugessen, KC, BCL, of MacDougall, MacFarlane, Scott and Hugessen. Born in Ashford, Kent in 1891, son of the first Baron Brabourne, educated at Eton and McGill, he stood unsuccessfully as a Liberal candidate in the general elections of 1935 against C.H. Cahan, and he was summoned to the Senate in 1937 . He was son-in-law to George H. Duggan, chairman of the board of the Dominion Bridge Co. The Knatchbull-Hugessens in England reverted to their original name of Knatchbull. In Canada, they tended to call themselves Hugessen, as in the case of Associate Chief Justice (of the Court of Queen's Bench of Quebec, and later Justice of the Federal Court of Canada) James K. Hugessen, son of the Senator and son-in-law of R.E. Stavert (son of Sir William Stavert of the Bank of Montreal), who in 1942 was vice-president of Consolidated Mining and Smelting under S.G. Blaylock. In England, Patricia Edwina Mountbatten, later Countess Mountbatten of Burma (daughter and heiress of the first Earl Mountbatten) in 1946 married John Ulick Knatchbull-Hugessen, later seventh Baron Brabourne. One of Hugesson's daughters, Mary, married Stephen Keynes, the son of the biographer Sir Geoffrey Keynes, who was the brother of the economist Maynard (Lord) Keynes and married to a granddaughter of Charles Darwin.

${ }^{32}$ MUA, MG1017, C75, James diary files, 9 July 1943.

${ }^{33}$ At the foot of his letter, Birks named the non-graduates on the board in 1911-12 as Lord Strathcona, Sir William Macdonald, George Hague, R.B. Angus, Sir William Van Horne, James Ross, Sir E.S. Clouston, W.M. Birks, G.E. Drummond, J.W. Ross, C.B. Gordon and F. Howard Wilson. 
He named the graduates as E.B. Greenshields, the Hon. J.S. Archibald, C.J. Fleet and Sir Thomas Roddick.

${ }^{34}$ Library and Archives Canada, Henry Birks \& Sons Family Papers, MG 30, A92, vol. 4, W.M. Birks to F. Cyril James, 13 July 1943.

${ }^{35}$ Bronfman was finally elected to the Board in 1970 although he had been a benefactor to the University since 1940. Various governors have been identified as his opponents, especially McConnell and W.M. Stewart, and various reasons have been cited for their opposition to him, notably his activity during the era of Prohibition in the US. What this quotation illustrates, in any case, was that widespread opposition to him in the Board was taken for granted.

${ }^{36}$ Library and Archives Canada, Henry Birks \& Sons Family Papers, MG 30 A92, vol. 4, W.M. Birks to F. Cyril James, 15 July 1943.

${ }^{37}$ See William Fong, J.W. McConnell: Financier, Philanthropist, Patriot (Montreal, Kingston, London, Ithaca: McGill-Queen's University Press, 2008), chapters 5 and 7.

${ }^{38}$ MUA, MG 1017, C75, James diary files, 10 July 1957.

${ }^{39}$ McConnell to Mr. and Mrs. Francis Wasserboehr, 15 December 1942, McConnell Papers.
${ }^{40}$ Morris Watson Wilson (1883-1946), CMG, LLD, DCL, born in Lunenburg, Nova Scotia, had begun his career with the Royal Bank there in 1897 and since 1934 had been president and managing director of the Royal Bank of Canada. In 1940, Lord Beaverbrook had him appointed as representative of the British Ministry of Aircraft Production in the United States and Canada, and he developed a plan for the production Merlin aircraft engines, and of 3,000 aircraft a month, in the US. In January 1941, he became deputy chairman of the British Supply Council in North America, and he succeeded Arthur Purvis as chairman in August of the same year. Three years later, he became the Canadian representative on the pulp and paper committee of the Combined Materials and Resources Board, a Canadian-American committee charged with addressing shortages. He was interested in the arts and philosophy as well as in economics and banking.

${ }^{41}$ As he wrote in 1956 to a daughter of his teacher in Muskoka, Mrs. D.C. Thomas, "I have been Senior Governor on the McGill Board for more than six years; and for a much longer time, Chairman of the Nominating Committee. During that time I have nominated and secured three Chancellors, including the present Chancellor, Mr. B.C. Gardner, exPresident and Chairman of the Bank of Montreal." (McConnell Papers, 25 October 1956). 


\title{
Islamic Studies Library: \\ Growth and Evolution
}

\section{by Sean Swanick}

\begin{abstract}
The Islamic Studies Library (ISL) was founded in 1952 in conjunction with the Institute of Islamic Studies (IIS). The founder, Dr. Wilfred Cantwell Smith, persuaded Principal F. Cyril James in 1951 that the study of Islam at McGill University was a worthwhile pursuit. From 1952 to the present, the ISL has grown from a modest 250 books to a collection of over 150, 000 volumes. The Library works to highlight and illustrate the breadth of Islamic civilization. This paper examines the ISL's growth and evolution in its 60 years of existence.
\end{abstract}

\section{RESUMÉ}

La Bibliothèque d'études islamiques (BEI) fut fondée en 1952 en conjonction avec l'Institut d'études islamiques (IEI). Le fondateur, le docteur Wilfred Cantwell Smith, a persuadé le Principal F. Cyril James en 1951 qu’il serait souhaitable que les études islamiques deviennent un domaine d'activité à l'Université. Dotée en 1952 d'une modeste collection de 250 livres, la BEI possède aujourd'hui plus de 150000 volumes. La Bibliothèque vise à mettre en relief et à illustrer l'ampleur de la civilisation islamique. Cet article examine la croissance et l'évolution de la BEI au cours de ses 60 années d'existance.

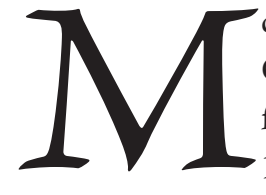
cGill University was founded by royal Charter from King George IV in 1821 following a bequest by James McGill (17441813), a Montreal merchant from Scotland who sought to nurture higher education in Lower Canada. In 1829 Medicine became McGill's first faculty and provided also the University's first library. In 1893 Redpath Library opened on McTavish Street as Canada's second free-standing academic library building, receiving major additions in 1901, 1921, and 1953. In 1969, McGill opened McLennan Library, contiguous with Redpath Library, as the University's new main library building. McGill's Library system now includes eleven libraries, designed to meet the teaching and research needs of faculty, students and staff. ${ }^{1}$

The Faculty of Divinity, established in 1948 but with roots extending back to the mid- $19^{\text {th }}$ century, hired a Professor of Comparative Religion, Dr. Wilfred Cantwell Smith (19162001) who in the early 1950's sought to give greater shape to this field through creation of an Islamic studies program. Principal F. Cyril James agreed to this proposal, and in May, 1951 named Smith the first Director of the Institute of Islamic Studies, Faculty of Graduate Studies. ${ }^{2}$

Dr. Smith envisioned for the Institute an "emphasis...on Islam as a contemporary and living force." ${ }^{3} \mathrm{He}$ strove to create a place of study in which Muslim and Christian students from East and West could sit side-by-side to foster interfaith dialogue and understanding. Smith also encouraged development of a specialized library for Islamic studies.

The Institute and Library both reflect Dr. Smith's background and vision as a scholar par excellence whose interests in the Muslim world stemmed from his having lived, studied and taught in India and Pakistan. ${ }^{4} \mathrm{He}$ recognized the need for dialogue between Western and Islamic civilizations that had much in common, but also harboured much misunderstanding of one another. The experience encouraged Smith to found an academic program that would promote interfaith dialogue.

The purpose of this paper is to discuss the early development of the Islamic Studies Library and some of the challenges it has faced, particularly from a collections development perspective. The Library maintains one of North America's most prominent collections in the field and shares the distinction, with Robarts Library, University of Toronto, of having Canada's largest and most diverse Islamic collection. Although collections have developed in other Canadian universities, such as Simon Fraser University's Centre for the Study of Muslim Civilization-modelled after McGill's Institute of Islamic Studies-no other University in the country boasts a more significant collection than McGill. Its unique holdings and rare books collections, in Middle Eastern and other languages, rank the Library among the finest Islamic Studies libraries in North America. 
As the oldest such collection in Canada, and the only one devoted exclusively to Islamic Studies, the Library reflects the growing maturity of Canadian librarianship, and the country's striving for cultural diversity and understanding. The adventure of the Islamic Studies Library may be situated in three stages: Early Years (1952-1984), Partington Report, 1984, and Recent Developments.

\section{Background}

The Islamic Studies Library like other McGill libraries focuses upon serving specific academic needs. Archival documentation for the early years hardly differentiates between the Library and the Institute. This close alignment has meant, on the one hand that the financial backing of the Library in its early years was left to the Institute's Director and faculty, and on the other hand that the Library's management resided during these years solely with its librarians and the Director of the Institute. Dr. Smith's success in obtaining start-up grants for the Institute and the Library from the Ford and Rockefeller Foundations, insulated and isolated the Library from the McGill Library system. ${ }^{5}$ Another factor contributing to the Library's relatively independent status until the early 2000s may have also been the specialized nature of its collections, particularly its language holdings. Unlike several other specialized McGill collections, the Islamic Studies Library has retained its separate housing and not been merged with another collection, or relocated to the McLennan Library.

Graduate students have always been the focus of the Institute, which in its early years had no undergraduates. For many years, the full complement of students, faculty and staff averaged about 25 people. ${ }^{6}$ This ability to remain small permitted a strong sense of community, with faculty, students, and staff, during Smith's era. In fact, for many of the early years faculty, students and staff would congregate for tea time together. This community spirit encouraged one student to state that

he had learned more of Islam from his experience of washing tea cups with a Muslim fellow-student than he had in his classroom experience.

In addition to students and scholars, the Institute has attracted over the years a wide range of dignitaries. Former Tunisian President, Habib Bourguiba visited in 1959, and gave the Library a Qurannic leaf, now housed in McLennan's Rare Books and Special Collections. ${ }^{8}$ In 1965 the late Shah of Iran, Mohammad Reza Pahlavi, during his visit donated a collection of Persian monographs. In 2010, the Hon. Mackenzie Clugston, Canadian Ambassador to Indonesia and the Association of Southeast Asian Nations, and Hon. Ferry de Kerckhove, former Canadian Ambassador to Egypt, visited the Institute and Library.
In terms of collections, the Library began with very small holdings, supplemented, however, by other modest, yet important Islamic Manuscripts collections held at McGill in the Osler History of Medicine Library and McLennan Library's Rare Books and Special Collections. The Osler collection, created by Sir William Osler (18491919), contains 130 Arabic and Persian manuscripts and one Ottoman-Turkish manuscript. ${ }^{9}$ The Rare Books and Special Collections Division holds two Islamic manuscript collections: the Blacker-Wood collection containing 300 manuscripts in Arabic, Persian and Urdu selected by the Ismaili scholar, Dr. Wladimir Ivanow (1886-1970) between 1925 and $1930^{10}$; and the Islamic collection containing 200 manuscripts in Arabic, Persian, Ottoman Turkish and Urdu. The role of Dr. Casey Wood (1856-1942), a renowned ophthalmologist, bibliophile, and McGill benefactor in developing these collections also deserves acknowledgement. As for the Islamic Studies Library, it holds over 200 manuscripts in Arabic, Persian, Ottoman Turkish and Urdu. Overall, McGill's Islamic manuscript collections now total approximately 700 items.

Use of these manuscript collections for academic projects has been greatly assisted by Adam Gacek's catalogues integrating the holdings of all three collections. ${ }^{11}$ A global project is currently underway, led by A. Gacek, Pam Miller (Osler Library), Dr. F. Jamil Ragep (Director of the Institute), and Dr. Faith Wallis (Dept. of History), analyzing the collections' most prominent manuscript, the nearly complete medicinal Herbal by Aḥmad ibn Muhammad al-GhāfiqīKitāb al-'adwiya al-mufrada (Book of Simple Drugs). ${ }^{12}$ A recent graduate student, Bogdan Smarandache, has used the collection in a forthcoming article on al-Majūsis's Kämil al-Sināah and the Wafǟîyah Sufi Order in Ottoman Egypt. ${ }^{13}$ The collections have also been the focus of several exhibitions in the McLennan Library: in 1973 on Persian and Arabic manuscripts ${ }^{14}$; in 1990 "Scribes and Scholars" on calligraphy ${ }^{15}$; in 2011 "Abū-Ḥāmid al-Ghazālī (1058-1111): Celebrating 900 Years," on the scholar al-Ghazāli16; "Book Culture in the Medieval Mediterranean” which highlighted book practices from the Mediterranean basin; and most recently in 2013 "Strokes and Hairlines: Elegant Writing and its Place in Muslim Book Culture" highlighting the importance of book culture in the cultural and religious history of Islam.

The Institute and Library for many years led a peripatetic existence. When the Institute first opened it was part of the Faculty of Divinity, now called the Faculty of Religious Studies, located in the Birks building. In 1957 the Institute moved to Cottingham House a four-storey mansion on Redpath Crescent which permitted expansion of the Library. ${ }^{17}$ Seven years later in 1964 the Institute and Library moved to the 9 th floor of the newly opened Leacock building. In 1983, they both moved yet again to their current home, Morrice Hall, which was gutted and rebuilt to meet their needs. 


\section{Early Years (1952-1984)}

At the institute's 1952 inauguration. Dr. Smith noted the importance of an Islamic Studies Library:

"my thesis is that the development of good Islamic Libraries, and of good Islamics Librarianship, is an intellectual task of the first order - one that requires technical skill in the librarian's craft, plus an authentic understanding of Islamic culture and civilization and even faith, plus an ability to synthesize these creatively." 18

These words set the tone for the Library even if it possessed barely 250 monographs, and was providing service during the first year for only six graduate courses, offered by three professors. Some of the early issues facing the Library were related to space, others related to cataloguing monographs-challenging yet surmountable tasks. When the Library first opened Dr. Smith was effectively Head librarian, although Dr. F.R.C. Bagley, lecturer in Arabic and Persian languages, served as part-time librarian. When William J. Watson became librarian in 1955, Bagley resumed full-time teaching. ${ }^{19}$
The Institute's initial goal was to provide "special emphasis to Islam as a religion, and to present-day developments in the Muslim world"20 through serving as a small graduate centre with a focus on research. This emphasis on teaching and researching Islam's past and present would ultimately require large-scale acquisition of publications from countries with predominantly Muslim populations. For reasons of space, and financial limitations, the Library emphasized Islam in the Arab Middle East, Turkey, Indonesia, Pakistan and India.

In September, 1954, to assist with the acquisition and organization of publications in Islamic languages such as Arabic, Baluchi, and Urdu, Dr. Smith wrote a "Memorandum on Library Development." This document illustrates his passion for libraries in general as well as his acute knowledge and understanding of the differing library traditions of Eastern and Western peoples. Smith noted that:

the body of knowledge, the conventions, the techniques and procedures that constitute [librarianship], and also the underlying concepts, some explicit and others unconscious, that undergird it, are a reflection, as they have been a product, of Western civilisation. ${ }^{21}$

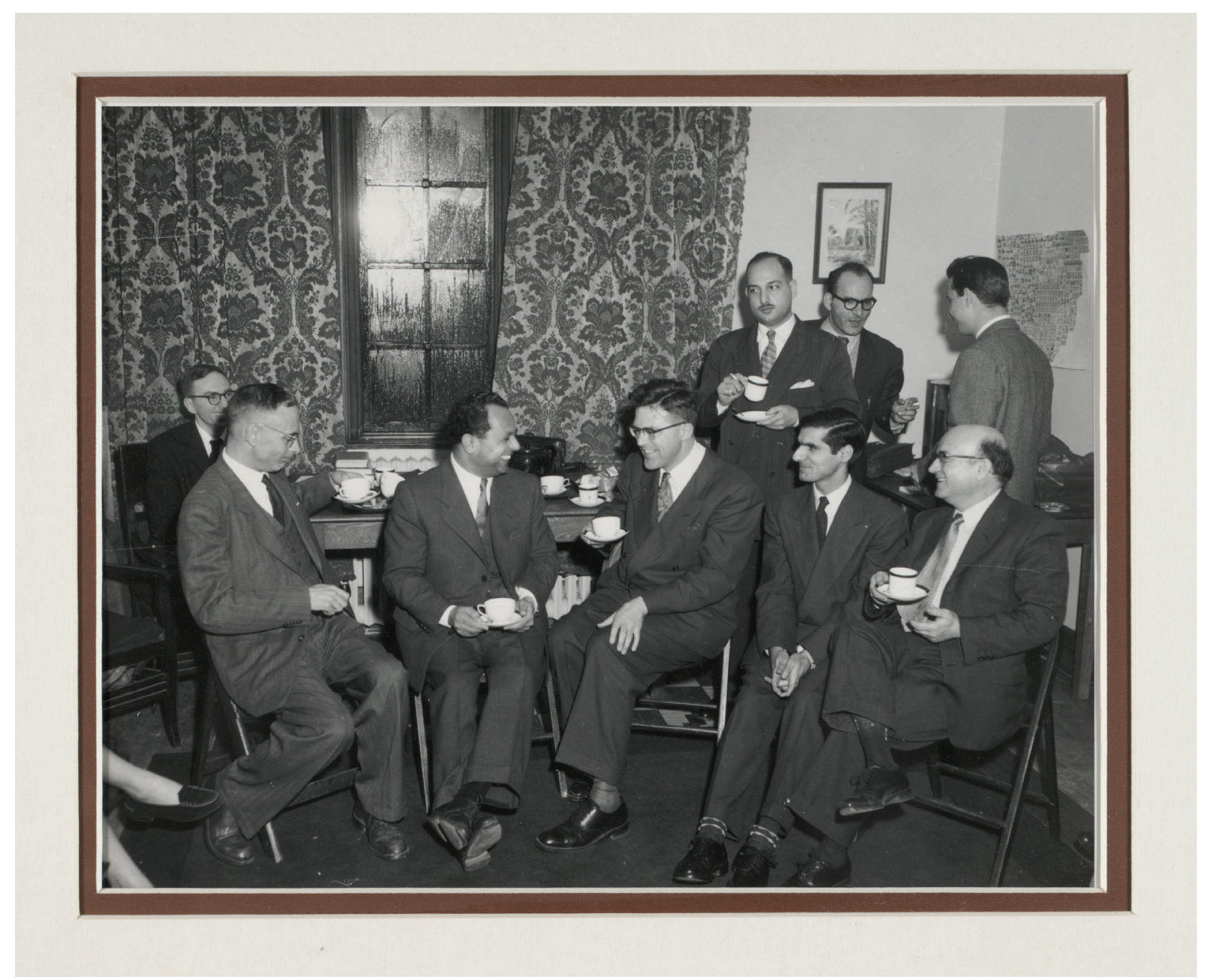

Figure 1. Tea time at the Institute of Islamic Studies, c. 1955 (Smith seated in the centre) 
The Memorandum explores the challenges faced in acquiring library materials from the Islamic world and notes three major issues in creating an Islamic Studies Library: i) the acquiring of books; ii) the processing of books; and iii) the training of personnel. All three are related in that the core requirements for a librarian in this field are linguistic ability and an understanding and sympathy for the Islamic world. These challenges and requirements persist to the present day.

The acquisition of books from the Islamic world remains a persistent issue, with many research libraries sending specialised librarians and other staff directly to Islamic countries to purchase materials. Although acquisition of materials from the Islamic world has improved dramatically, Paul Sprachman-former Middle East librarian at the University of Chicago - noted in 1982 that:

book buying in the Middle East involves tracking down someone who knows someone else who has valuable materials, drinking countless cups of tea and praising the tea, not the books. ${ }^{22}$

The problem of classifying Islamic materials was remedied for the Library in 1960 when Smith and William J. Watson, librarian of the Islamic Studies Library (1955-1965) devised the "Smith-Watson Classification system" to accommodate Islamic publications. As Smith noted, librarianship was a Western affair with developed systems, classification and otherwise, for Western materials and Western libraries. The Dewey decimal classification system, the Library of Congress classification and cataloguing systems, their name and subject authority files, and the UNESCO systems, are examples of universal bibliographical control mechanisms that did not easily accommodate Islamic publications. ${ }^{23}$

The Smith-Watson Classification system divided Islamic studies into five categories:

1) Reference materials;

2) Extra-Islamic subjects (including Religion/

General, Orientalism and Orientalists; History,

Economics, Politics, and Law, among other topics);

3) Islam, Classical Period, i.e. prior to 1800;

4) Modern Islamic World, i.e. post 1800; and

5) General Geographical Divisions.

These five categories, each with 5-12 subcategories, were used to classify the Library's collection.

Although the Smith-Watson Classification system was a major accomplishment, it remained a McGill novelty and would be adopted by no other Islamic or Middle East Library in North America or beyond, due partly to lack of resources for further development. In the 1980s, the Library of Congress classification system began adapting to better meet the needs of Islamic publications. Previously, LC classification's had suffered from a Western-centric perspective, with Islam subsumed under Christianity. Development of the BP class permits a broader and less-Western centric classification of materials on or about Islam. A continuing drawback is that the BP class is not reserved exclusively for Islam, but is also used to organize publications by and about Theosophy, Baha'ism, and other religions. By comparison, Smith-Watson classification was devised specifically for Islamic materials, and remains a landmark in Islamic Studies librarianship.

In 1964 Dr. Smith left McGill for Harvard University's Divinity School, and was succeeded as Director of the Institute by Dr. Charles J. Adams. Although not as preoccupied with librarianship as Smith, Adams continued supporting the Library. During this period the collection enjoyed strong, but uneven development. Until the late 1980s, selection was undertaken by the professors, librarians and students, in that order. Through their efforts and dedication, employing a variety of strategies, the collection grew steadily with titles in many different formats from all over the Islamic world.

In 1954 the Institute borrowed from the Süssenheim collection, Yale University, over 1,000 uncatalogued items in modern Turkish. As the Library's staff possessed the necessary language skill, McGill agreed to catalogue them. In 1959, the catalogued titles were returned to Yale, except for approximately 250 items purchased at 25 cents each. These titles provided the foundation for the Library's Turkish collection, which prompted the research and writing of the seminal work by Dr. Niyazi Berkes, Professor of Turkish studies, The Development of Secularism in Turkey, (McGill University Press, 1964) the first analysis of Kemal Atatürk's secularization policies in the early years of the Turkish republic. ${ }^{24}$

By 1973 the Library held 70,000 volumes including monographs, serials and manuscripts. ${ }^{25}$ Some of these holdings were rare, for example the Urdu serial titles acquired by the Librarian, Muzaffar 'Ali (1967-1976), during his trips to Pakistan. Other holdings of interest include the Turkish incunabula publications by İbrāhīm Müteferrika, of which McGill has sixteen of eighteen titles. These are noteworthy not simply because they are incunabula but also because only four other libraries are known to have such a large number. The Müteferrika press was a landmark in the Islamic world. It illustrated the effectiveness of the printing press, otherwise viewed with trepidation. ${ }^{26}$

\section{Partington Report: 1984}

By 1984 the collection had grown to 80,000 items. ${ }^{27}$ Even though the Library's central role within the Institute was fully acknowledged, there was awareness that more coherent administrative and collection development policies might be in order. As a result, a consultant was hired. In October, 1984, Dr. David H. Partington, Middle East Studies Librarian, Harvard University, undertook the Library's first evaluation. Along with criticisms and suggestions on how best to proceed 


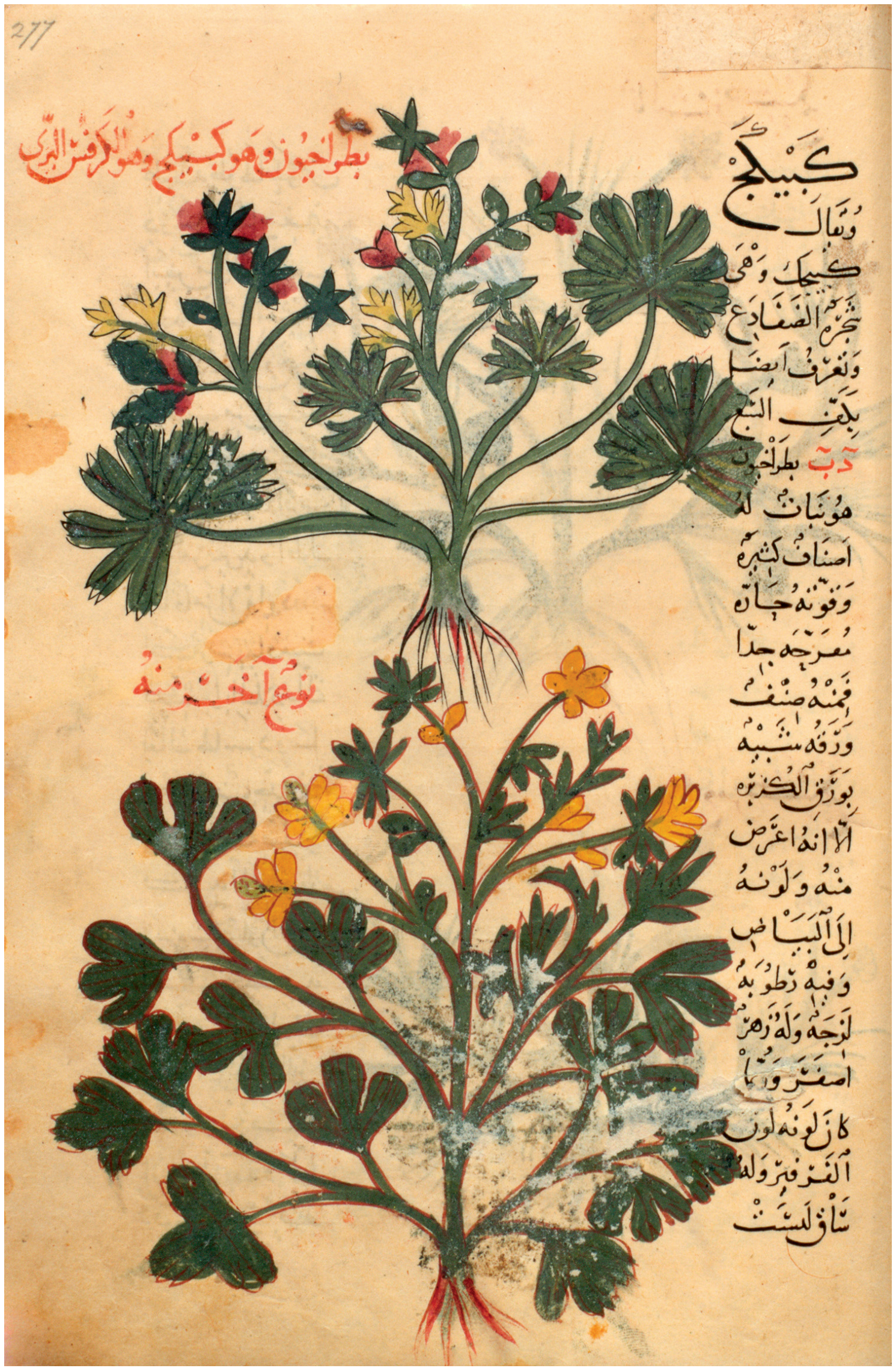

Figure 2. The 'Herbal' manuscript of Abū Ja far Aḥmad ibn Muhammad al-Ghāfiqī 
into the future, his report led to the Library emphasizing the collection as its greatest strength. Partington noted that:

although I read the librarians' annual reports carefully, I have not found evidence of the continued existence of well-organized acquisitions effort. While attention has been paid to acquiring specific titles from European dealers, especially for out-ofprint orientalia, there is little evidence that welldeveloped standing orders were ever instituted. ${ }^{28}$

Partington was generally critical of the Library's management, noting its lack of effectiveness, and the need for intervention by McGill's Library system. The problem was that the Library had two masters, the Director of the Institute and the Director of Libraries, who could easily have divergent views on its role and function. ${ }^{29}$ The predominant voice of the Institute was due, of course, to professors having major responsibility for collection development, and the Institute being the main financial backer. Although Partington did not address the issue directly, the lack of a Head Librarian from the late 1970s until 1987 was symptomatic of managerial problems.

Partington evaluated the collection by shelf reading and searching the catalogue, and by comparing McGill with Harvard's Center for Middle Eastern Studies, founded in 1954, two years after the Institute. This comparison between McGill and Harvard has been a long standing source of concern for observers as the two institutions have such different histories and priorities. The Harvard Semitic language collection development began in the late 17th century while McGill's earliest Islamic collection began in the early 20th century. Harvard's program encompassed Middle Eastern Studies with a strong focus on the social sciences, whereas McGill focused almost exclusively upon the humanities. Unlike McGill, as Partington noted, Harvard strove for an area-wide collection to complement its multidisciplinary research and teaching agenda. Area studies collections developed in the mid-20th century United States, reflecting its world power status. ${ }^{30}$ By comparison, research and teaching at McGill focused upon the humanities with a particular interest in textual analysis-in the classical

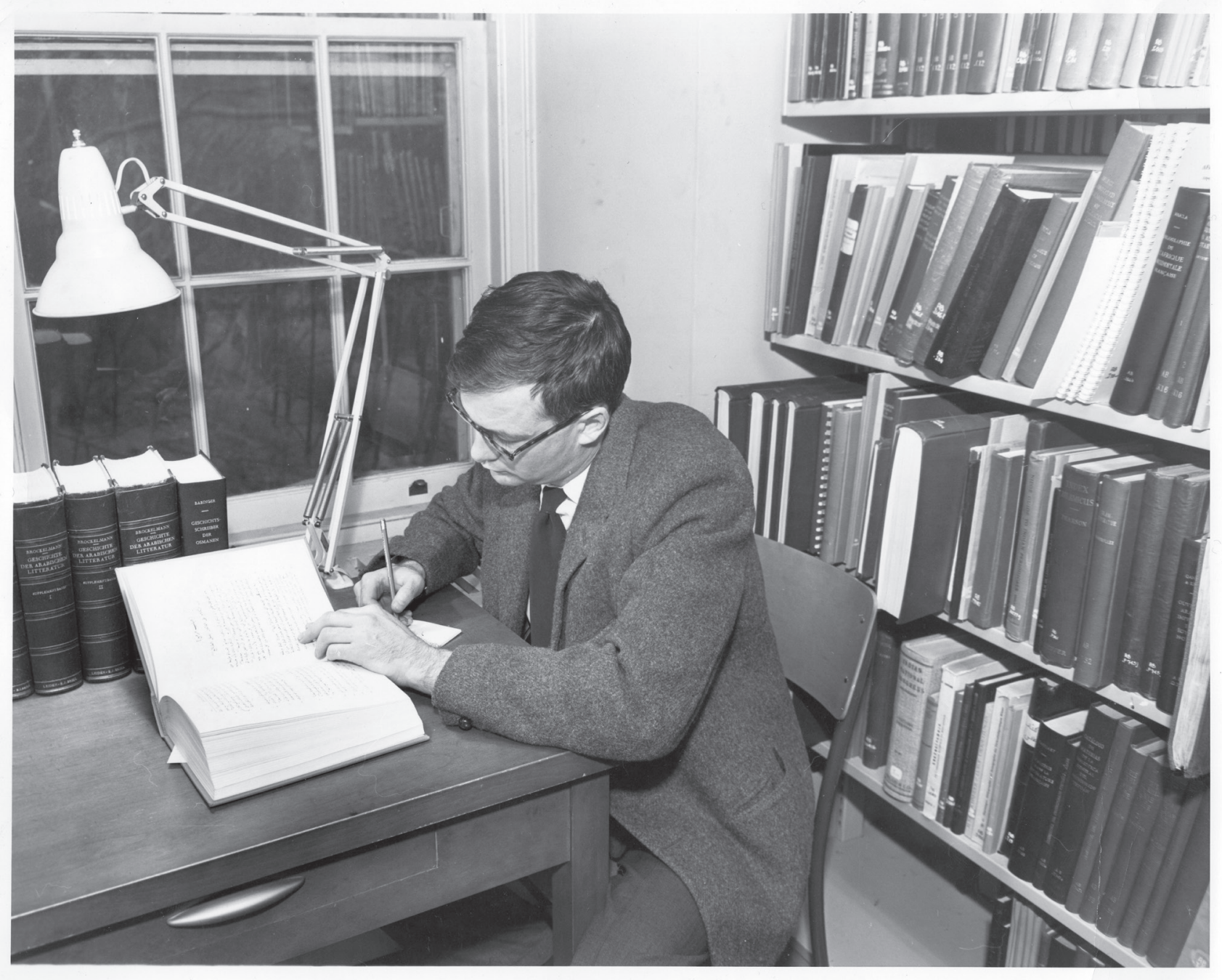

Figure 3. William J. Watson, First Librarian of the Islamic Studies Library, c. 1955 


\section{919 . \\ .S $9663 t$}

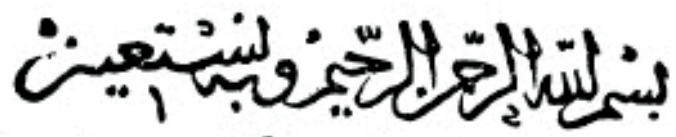

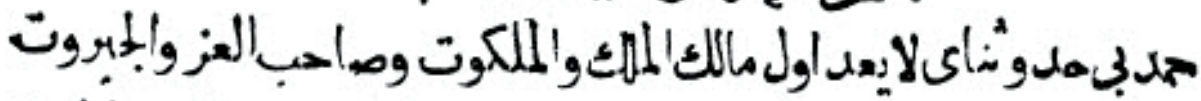

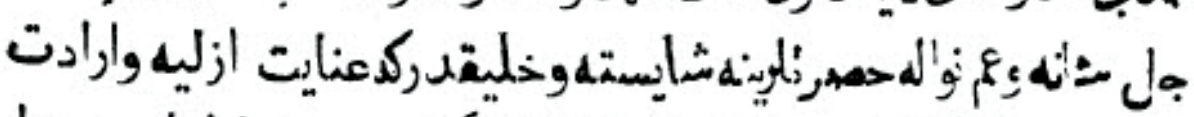

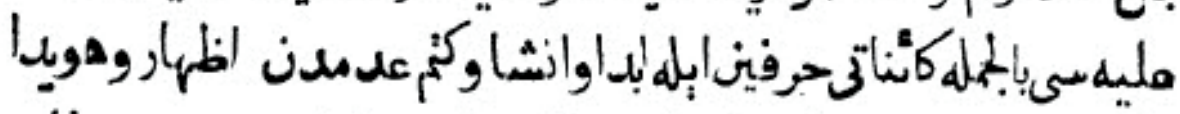

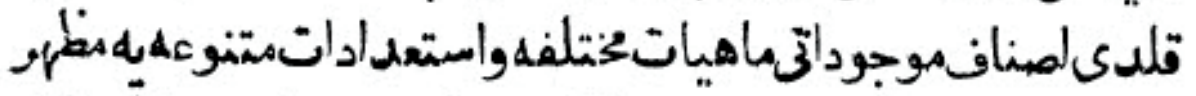

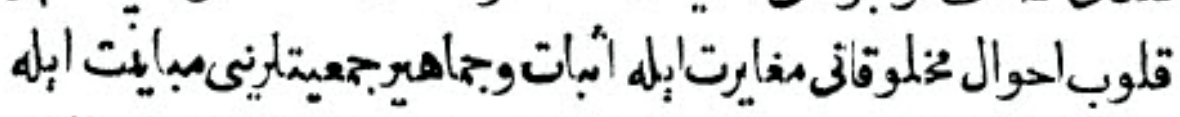

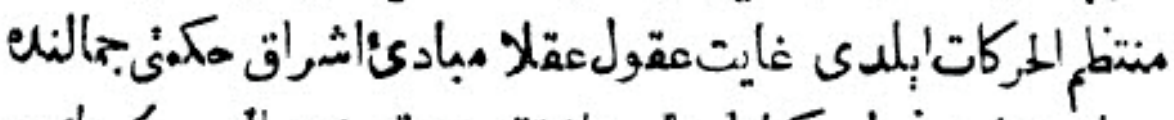

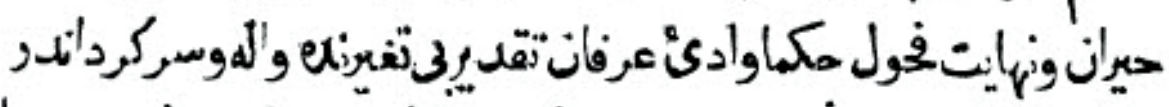

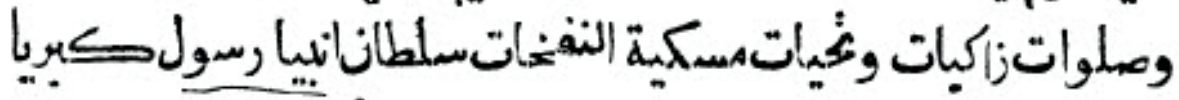

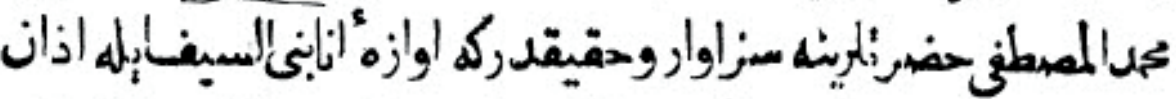

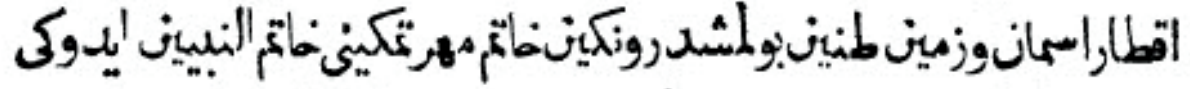

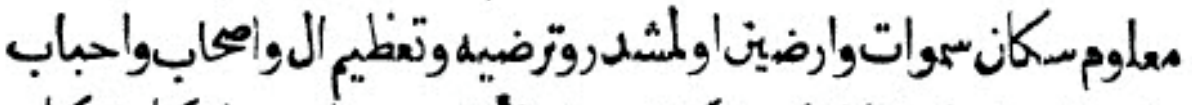

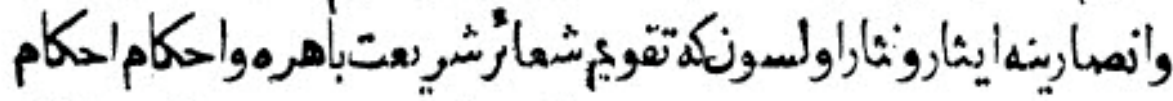

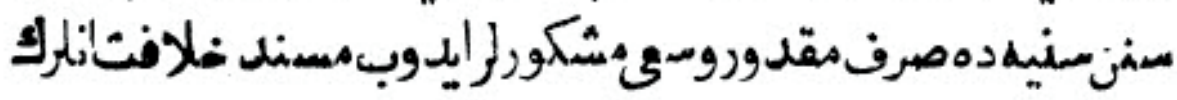

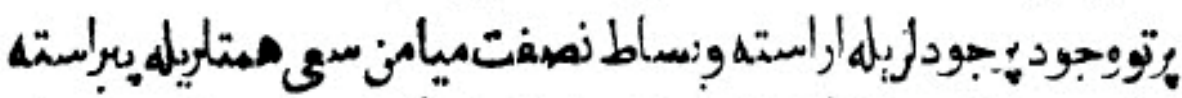

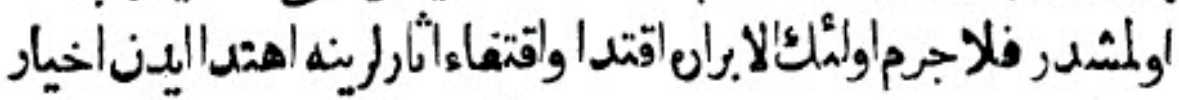

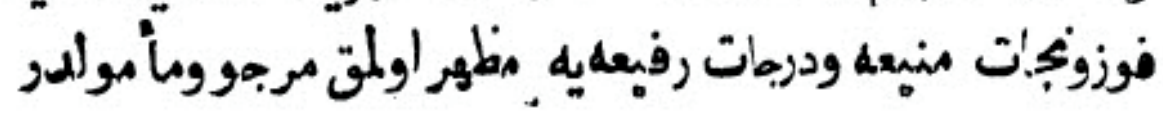
ويعل 
Orientalism style of 20 th century European programs. Finally, unlike Harvard's Center for Middle Eastern Studies, neither the Institute nor its Library was geographically centred, but was focused instead on Islam and the Muslim peoples not only in the Middle East but also in regions not traditionally collected by Harvard such as South, South East, and Central Asia, India and Pakistan.

The overall assessment of the collection was:

good in mainstream, conventional Islamic studies; below strength in Arabic, Turkish, Persian belleslettres; generally good in secondary literature; weak in peripheral areas, such as North Africa and Afghanistan; generally weak in German works on the Middle East; and not strong enough in periodical literature e $^{32}$

Questions can be raised about aspects of Partington's methodology. Sadiq Hidayat (1903-1951) — an important Iranian writer of fiction - was a name used to test the extent of the Library's holdings of important authors, despite his being of peripheral interest to the Institute's area of study. Little or no attention was paid, however, to the Library's strength in Qurānic studies, Tafsīr (Qur'ānic exegesis or commentary), Hadith (sayings and actions attributed to the prophet Muhammad), Sufism (mystical Islam) - topics of major interest to the Institute.

A year later, Ms. Norma Johnston, Religious Studies Librarian, in her role as acting Head of the Library, responded to Partington's report by addressing both collections development and administrative issues. Her critique of Partington's recommendations on collections was balanced and nuanced. She felt that he placed too much emphasis upon collection numbers and too little upon collection development issues such as filling glaring gaps in holdings in areas like audiovisuals and microfilms, and the rare book collection. ${ }^{33}$ Otherwise, they concurred that the collection had

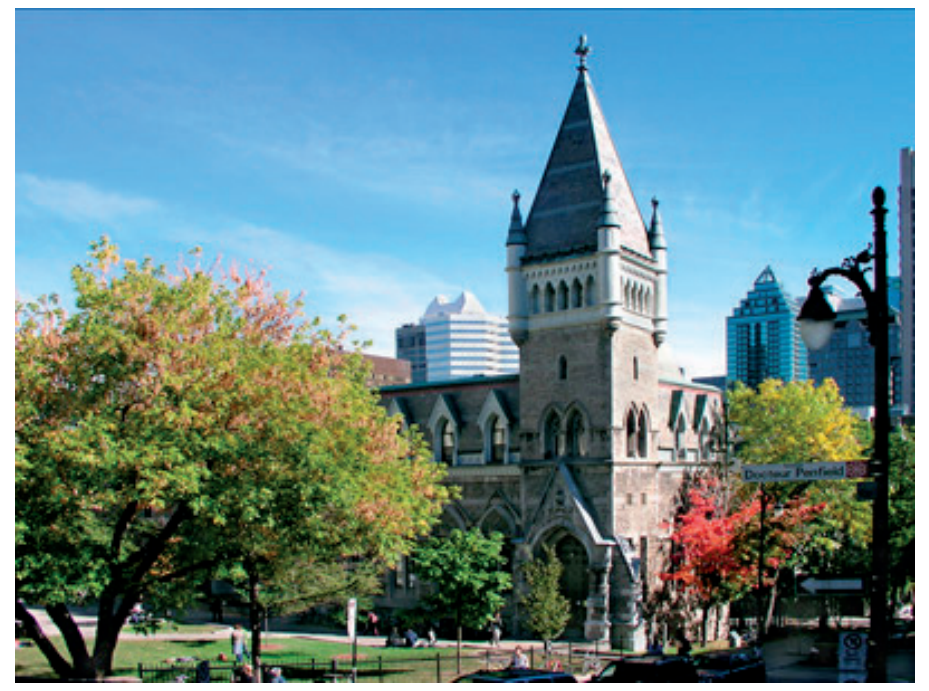

Figure 5. Morrice Hall, c. 1990 grown mostly in fields that interested faculty. The reference collection remained intertwined-conflated-with the regular circulating materials. As for suggestions that a librarian be sent to the Middle East on book buying expeditions, she expressed strong reservations. On the administrative front, Johnston identified two major problems. The first was a lack of a Head Librarian since the late 1970s, and the need for someone with a specialist background. The second was the financial implication of such an appointment. ${ }^{34}$ The Institute remained the main financial backer of the Library. As Johnston noted

for the most part, the funds for books, journals, and binding, and some salaries, have come from special sources other than the McGill budget. ${ }^{35}$

Planning further than a year in advance was precarious given the fluctuation in funding.

\section{Recent Developments}

In 1987, Mr. Adam Gacek, a respected librarian and scholar, Institute of Ismaili Studies in London, England, became head of the Islamic Studies Library. His arrival signalled a change of course for its collection development. The 198788 Annual Report notes that Mr. Gacek spent much time assessing the collection against various Islamic and Middle East Studies bibliographies, and acquiring missing and necessary reference materials notably the Arabic biographical dictionaries identified by University of Exeter Middle East Studies librarian, Paul Auchterlonie. ${ }^{36}$ Creation of a separate reference collection, a periodicals room, and a special collections section in 1989 clearly defined the Library, making it more suitable for serious research. A more appropriate and holistic collection emerged in which the gaping lacunae that had developed over the years, as identified by Partington, began to be filled.

Over the past two decades the Institute and the Library have undergone significant transformation. Collection policy for the Library has been refocusing to reflect the changing research and teaching priorities of faculty and graduate students. Core teaching areas are increasingly concerned with contemporary issues such as Persian anthropology, current Middle Eastern politics and history, and modern Arabic literature. A social science approach to research is supplanting the Institute's long-standing humanities approach. ${ }^{37}$

From a managerial perspective, the Institute's faculty is less involved in the Library's operation and collection development than it had been in the past. Whereas the Institute had previously covered most of the Library's costs, the Library system now provides $95-100 \%$ of its budget. The system's operational and collection's policies are now closely followed. Nevertheless, relations between the Library and its core Islamic Studies faculty and students remain close and collegial. 


\section{Conclusion}

During the past 60 years, the Islamic Studies Institute has become a world-renowned centre for teaching and research. The Library has played a central role in this achievement, through developing outstanding collections that attract scholars from across the world, and through the expertise and commitment to service by its librarians. Evolution and adaptation in meeting the challenges of Islamic and Middle Eastern Studies remains the goal of McGill University's Islamic Studies Library.

\section{ENDNOTES}

${ }^{1}$ P. McNally. 2001. "McGill University Libraries." International Dictionary of Library Histories, ed. by David Stam. Chicago: Fitzroy Dearborn, v. 1, pp. 436-438.

${ }^{2}$ H. Keith Markell. 1979. The Faculty of Religious Studies, McGill University, 1948-1978. Montreal: Faculty of Religious Studies, McGill University, p. 33.

${ }^{3}$ Letter of W.C. Smith to Principal F.C. James, May 26, 1951. McGill University Archives, file number 634 RG84 Container 681043 C.

${ }^{4}$ Hillary Putnam, D. Eck, J. Carman, T. Wei-Ming, and W. Graham. 2001. "Wilfred Cantwell Smith: In memoriam." Harvard Gazette. Accessed 12 February, 2012: http://news.harvard.edu/gazette/2001/11.29/27memorialminute.html

${ }^{5}$ David Webster. 2009. Fire and the full moon: Canada and Indonesia in a decolonizing world. Vancouver: UBC Press, pp.92-95.

${ }^{6}$ Charles J. Adams. 1962. "The Institute of Islamic Studies." Canadian Geographical Journal, 65 (2), p.35.

p.15. . 1965. "Understanding the Muslim World." McGill News, 46 (3),

${ }^{8}$ A. Gacek. 1990. "Early Qur'anic fragments," Fontanus, 3, pp. 45-64.

${ }^{9} \mathrm{~S}$. Roman. 1990. The development of Islamic library collections in Western Europe and North America. London: Mansell, p.241.

${ }^{10}$ Wladimir Ivanow, and Casey A. Wood. 1927. "Annotated catalogue of the Casey A. Wood Collection of Persian, Arabic and Hindustani manuscripts." [Photocopy of typescript], located in Rare Books and Special Collections.

${ }^{11}$ A. Gacek. 1991. Arabic manuscripts in the libraries of McGill University: union catalogue. Montréal: McGill University Libraries. 2005. Persian manuscripts in the libraries of McGill University: brief union catalogue. Montréal: McGill University Libraries. 1996. Arabic lithographed books in the Islamic Studies Library, Mc Gill University: descriptive catalogue. Montréal: McGill University Libraries.

${ }^{12} \mathrm{~J}$. Solomon. 2012. "Ancient Secrets Revealed." headway: Research, discovery and innovation at McGill University. Accessed 20 Feb., 2012: http:// publications.mcgill.ca/headway/magazine/ancient-secrets-revealed/; A. Gacek. 1989. Arabic calligraphy and the "Herbal" of al-Ghâfiqî: a survey of Arabic manuscripts at McGill University. Montréal, Québec: McGill University Libraries; and Abū Ja'far Aḥmad ibn Muhammad Ghāfiqī, and Eleonora Di Vincenzo. 2009. Kitab al-adwiya Al-Mufrada' 'Abu Ga'far'Ahmad b. Muhammad b. 'Ahmad b. Sayidd Al-Gafiqi (XII sec.) : edizione del capitolo 'Alif. Pisa: F. Serra, pp. xix-xxi.

${ }^{13}$ B. Smarchande. 2011. "Notes on a Manuscript of al-Majūsīs Kāmil alSināah and the Wafǟìyah Sufi Order in Ottoman Egypt." Unpublished paper.

${ }^{14}$ E. Lewis. 1973. "Current Exhibition-McLennan Library, McGill University Libraries. February-mid March 1973. Persian and Arabic Manuscripts." [Original typescript,] currently at Islamic Studies Library to be transferred to McGill University Archives.
${ }^{15}$ S. Wilson. 1990. "Helping our understanding of Islamic cultural achievements: Rare, exotic, and beautifully written and decorated Arabic works," The Montreal Downtowner (August 15), p.13.

${ }^{16}$ S. Swanick. 2011. Abū Hāmid al-Ghazālī (1058-1111): An exhibition held in the Humanities \& Social Sciences Library, McGill University: August 15, 2011-March 31, 2012. Montréal: McGill University Library.

${ }^{17}$ D. Webster. 2009. Fire and the full moon: Canada and Indonesia in a decolonizing world. Vancouver: UBC Press, p. 93.

${ }^{18}$ [No author.] 1973. "McGill Islamic Library: An introduction." [Draft. Submitted to Dr. Richard A. Farley, Director of McGill University Libraries.] [Original typescript,] currently at Islamic Studies Library to be transferred to McGill University Archives.

${ }^{19}$ W.C. Smith. 1954. "Memorandum on Library Development" (including addendum submitted to Ford Foundation). Original typescript,] currently at Islamic Studies Library to be transferred to McGill University Archives.

${ }^{20}$ W. J. Watson. 1964. "Research Seminar Paper on Library Development." [Original typescript], currently at Islamic Studies Library to be transferred to McGill University Archives. N.B. It seems that the Institute and Library coordinated on a seminar series in the 1960 s until the early 1970 s. There are a number of student essays on the Library, often detailing its collection, history, staff and development. There is no definitive source that I found that explains what course was involved, who taught the seminar or who the audience was.

${ }^{21}$ W.C. Smith. 1954. "Memorandum on Library Development," p. 2. File copy, currently at Islamic Studies Library to be transferred to McGill University Archives.

${ }^{22}$ L.R. Pearson. 1982. "Perils and Pitfalls of Mideast Acquisitions." American Libraries, 13 (2), p. 117.

${ }^{23}$ W. J. Watson. 1964. "Research Seminar Paper on Library Development," p.7. One example of the issues faced when cataloguing Islamic materials, particularly for Arab names is the division of the name. Arab culture, generally speaking and particularly until recently, devised names according to family lineage and often using the surname, as understood in a Western context, from the town, village or city in which an individual was born. Thus, the full name of the eminent medieval scholar Abū Hāmid al-Ghazāli is Abū Hāmid ibn Muhammad al-Ghazālī al-Tūsi; Abū signifies the father of Hāmid, ibn signifies the son of Muhammad, al-Ghazālī represents what is known as a laqab, or nickname which is often the unique name of an individual (becoming the surname as understood in the West) and al-Túsi signifies he is from the town of Tüs in northern Iran.

${ }^{24}$ W. J. Watson. 1958. "Osmanli books borrowed from Yale University." McGill University Archives, file number 4366 RG 40 Container 442065 B.

${ }^{25}$ [No author.] 1973. "Institute of Islamic Studies." [Original typescript], currently at Islamic Studies Library to be transferred to McGill University Archives.

${ }^{26}$ Alastair Hamilton, Maurits H. van den Boogert, and Bart Westerweel. 2005. The Republic of Letters and the Levant. Leiden: Brill, pp.269-270; Watson, William J. 1968. "İbrāhīm Müteferrika and Turkish incunabula." Journal of the American Oriental Society, 88 (3), pp. 435-441; and Sean E. Swanick, "İbrahim Müteferrika and the printing press: A Delayed Renaissance." Papers of the Bibliographical Society of Canada. : Cabiers de la Société bibliographique du Canada. (Forthcoming, 2014.)

${ }^{27}$ N. Johnston. 1985. "Cyclical Review of the Islamic Studies Library," [original typescript], p.11. Currently at Islamic Studies Library to be transferred to McGill University Archives.

${ }^{28}$ D. H. Partington. 1984. "The Islamic Library at McGill University: A report and evaluation," p.12. File copy, currently at Islamic Studies Library to be transferred to McGill University Archives.

${ }^{29}$ Ibid., p.13.

${ }^{30}$ Labib Z. Yamak. 1968. "The Middle Eastern collections of the Harvard Library." Harvard Library Bulletin XVI (4).

${ }^{31}$ İbrahim Müteferrika, Kâtip Çelebi, and Francis North. 1730. Tarikh al-Hind al-gharbi al-musamma bi-Hadith-i naw. Qusțantiniyah (Constantinople): Dār al-Tíibāah al-Ma'mūrah. 
${ }^{32}$ D. H. Partington. 1984. "The Islamic Library at McGill University: A report and evaluation," p.12. File copy, currently at Islamic Studies Library to be transferred to McGill University Archives.

${ }^{33}$ N. Johnston. 1985. "Cyclical Review of the Islamic Studies Library," p.11. [Original typescript], currently at Islamic Studies Library to be transferred to McGill University Archives.

${ }^{34}$ Ibid., p.12.
${ }^{35}$ Ibid., p.23.

${ }^{36}$ A. Gacek. 1988. "Islamic Studies Library, Annual Report: 1987-88." [Original typescript], currently at Islamic Studies Library to be transferred to McGill University Archives.

${ }^{37}$ M. Abley. 2008. "Understanding Islam," McGill News. Spring/Summer, pp. 23-27. Accessed 20 Feb., 2012: https://publications.mcgill.ca/ mcgillnews/2008/08/24/understanding-islam/. 


\title{
McGill University and Quebec City in the 1960s
}

\section{by Peter F. McNally}

\begin{abstract}
In Canada and throughout the Western world, the 1960s was a tumultuous decade of student unrest and social/political upheaval. For Quebec, the 1960s was also the decade of la Revolution tranquille/Quiet Revolution, when francophone society's self-definition underwent fundamental change. For McGill University, the decade's changing environment required enormous adaptation: maintaining and extending academic programs and standards, restructuring governance and administration, expanding the physical plant, accommodating growing enrolment, seeking adequate funding, and adjusting to Quebec's changing reality. A wide range of primary and secondary sources is available in recounting the story of McGill's role in Quebec during the 1960 s.
\end{abstract}

\section{RESUMÉ}

AuCanada ainsi que partout ailleurs danslemondeoccidental, les années 1960 furent une décénnie d'agitationétudiante et de perturbations sociales et politiques. Au Québec, les années 1960 furent aussi la décénnie de la Révolution tranquille, durant laquelle la manière dont la société francophone se définissait elle-même a subi un changement fondamental. Dans le cas de l'Université McGill, les transformations de l'environnement durant cette période ont nécessité énormément d’adaptation: le maintien et l'expansion des programmes et des normes académiques, la restructuration de la gouvernance et de l'administration, l'agrandissement des installations, l'accomodation du nombre croissant d'inscriptions, les efforts déployés pour assurer un financement adéquat, et l'ajustement de l'Université aux changements vécus par le Québec. Un large éventail de documentation primaire et secondaire est disponible pour relater l'histoire du rôle de McGill au Québec durant les années 1960.

1 970 brought crisis to McGill University as it did to Quebec and Canada-but in different months, for different reasons. For McGill June brought a funding crisis, whereas for the province and the country October brought the FLQ crisis. Both at the time, and subsequently, 1970 would generally be identified with la crise d'Octobre/ October Crisis and the FLQ-Front de libération du Québec/Quebec Liberation Front. For McGill, however, the June crisis was initially more important_involving as it did the internal operations of the University and relations with Quebec City. At the time, the October FLQ crisis, although centered upon Quebec with national and even international ramifications, affected only peripherally most individuals and institutions such as McGill. The long term consequences from both crises would reverberate throughout the final decades of the century and beyond.

On May 12, 1970 a new Quebec government was sworn into office-having defeated the previous government two weeks earlier in a Quebec general election-with Robert Bourassa as Premier (1970-1976) and Guy St. Pierre as Minister of Education. Shortly thereafter annual operating grants from the government to provincial universities were announced. To McGill's surprise, its Quebec grant would be nearly \$3M less than anticipated: $\$ 25.2 \mathrm{M}$ instead of $\$ 28 \mathrm{M}$. As the University had already budgeted for a $\$ 3 \mathrm{M}$ shortfall between its revenue and expenditures, the result would be a $\$ 6 \mathrm{M}$ annual deficit to be covered by investments and gifts. As the operating budget was less than $\$ 60 \mathrm{M}$ - and less than $\$ 45 \mathrm{M}$ if research grants are excluded-this shortfall represented a disturbingly high proportion of anticipated income. Principal H. Rocke Robertson (1962-1970) brought the matter immediately to the Board of Governors, which on June 25 established a Special Committee to "explore and develop alternative models for the operation of the University within the constraints foreseen in the next five years." Composed of Board, Senate, faculty, and student representatives, this committee would be Robertson's last initiative before stepping down as Principal on August 21. He worked in consultation with his successor Robert E. Bell (1970-1979), who continued the work of the Special Committee. ${ }^{1}$

\section{The 1960s}

Robert Bell inherited a University whose internal and external realities had been deeply altered during the 1960 s. 
For the Western world generally, including Canada, the '60s was a decade of great prosperity and profound cultural change. The youth generation created a counter-culture movement characterized by anti-war sentiments and opposition to nuclear weapons and the Viet Nam war, as well as by drugs, distinctive music, and relaxing sexual attitudes-among other things. Public demonstrations, sometimes violent, occurred with great regularity on behalf of causes such as an increased role for students in university government. Well educated and prosperous young flag bearers of the post World War II baby boom generation took for granted that they would soon take charge of the world. Ironically, rising youth activism coincided with collapse of the baby boom, enabled in part by female oral contraceptives - the "pill". Feminism and the rising profile of women in society would influence all aspects of late $20^{\text {th }}$ century life, including universities, as part of a major social transition. Computers and automation also emerged as a regular part of daily life.

For Canada, the '60s were notable for, among other things, enhanced government involvement in society-specifically health, education, and welfare. Both a national health insurance plan and the Canada Pension Plan (CPP) were introduced by Ottawa. Appreciating that the country's future depended upon an educated population able to cope with current and projected needs, particular attention was placed upon higher education which experienced a golden age of financial support unprecedented in Canadian history. Democratization of Canadian higher education and its participation in mass education would now begin. ${ }^{2}$

Within Quebec, la Revolution tranquille/Quiet Revolution was launched by the 1960 defeat of the long serving Union nationale party-led for most of its tenure by Maurice Duplessis (1890-1959)-and its replacement by the Liberal government of Jean Lesage (1912-1980). Laissez-faire social and economic policies of the past were replaced by activist government intervention. The Roman Catholic religion as the vehicle for expressing and maintaining French-Canadian nationalism-organizing and operating its social, cultural, and educational life - was thrown aside in favour of secular nationalism. The French language - not the Church - would now emerge as the primary vehicle for expressing FrenchCanadian-Québecois(e)-nationalism. Quebec's government would increasingly conduct itself as a "national" government-organizing economic, social, cultural, and educational activities in support of the majority Francophone population. In parallel, Montreal's Francophone business elite began supplanting Anglophone business leadership as the city's financial activity became increasingly more focused upon Quebec and less upon Canada. The province developed the Quebec Pension Plan (QPP), distinct from the CPP. An attitude of "maitres chez-nous"-masters of our own house-was in full swing. As for the two hundred year old English-language community, it began wondering about its future in the province as proposals emerged for promoting the French language and curtailing English. Proposals also emerged for rebalancing Quebec's role within Confederation, or even separating the Province completely from Canada. Although advocates of these new proposals were generally peaceful and constitutional in their approach, radical groups did emerge advocating violent change.

\section{Higher Education}

Education emerged as a particular concern of the province. Although there had been a Department of Instruction publique/Public Instruction from 1868 to 1874, for ninety years thereafter separate Catholic and Protestant committees oversaw Quebec's educational affairs at the school level; at the post-secondary level there was no effective overview. In 1964, a Department of Education was created. Armed with the Report of the Parent Commission royale d'enquête sur l'enseignement/Parent Royal Commission of Enquiry on Education (1965/66), the new Department concerned itself immediately with higher education generally and universities specifically in a way never previously experienced by McGill and its sister institutions. Developing a Quebec system of higher education emerged quickly as a priority.

This newly awakened concern with higher education would have considerable - but different - impacts upon both Anglophone and Francophone communities. Francophone higher education had long revolved around two distinct types of institutions: collèges classiques/classical colleges and universities. Both types of institutions were private, charged fees, and were run by teaching and administrative staffs composed largely or exclusively of Roman Catholic clergy. Collèges classiques provided both high school diplomas and baccalaureate degrees, wed closely to the classical Trivium (literary \& philosophical) and Quadrivium (mathematical \& musical) curriculum. Despite some success at modernizing and introducing science and the social sciences, a strong humanities and religious orientation suffused the curriculum. By comparison, the province's three French-language universities-Laval (origin 1663, established 1852), Montréal (origin 1878, established 1919), and Sherbrooke (established 1954)-defined themselves as graduate and professional institutions, requiring degrees from a collège classique for admission. University entrance would typically occur after successful completion of 15 years of study in primary school and collège classique, the latter serving as undergraduate faculties of arts for their affiliated universities. Although this system had its undoubted strengths and benefits, it was inherently elitist and did not lend itself to late $20^{\text {th }}$ century curricula and democratic, mass education. Nor did it lend itself to developing research intensity. The approximately 100 collèges classiques, each averaging a few hundred students, with their exclusive atmospheres, arcane curricula, and fees were uninviting for most people. As the required path 
to university admission, they were too parochial, while the universities themselves were too narrowly focused. ${ }^{3}$

For the Anglophone community, including the Protestant school boards that dominated its primary and secondary education, long-standing practice ensured general compatibility with curriculum found elsewhere in English-speaking Canada and the world. After successfully completing 11 years of primary and secondary schooling, students could enter university as undergraduates. Upon successful completion of 4 years, or 3 years if university was entered after grade twelve, a Bachelor's degree would be conferred. Bishop's University (established, 1843) and Sir George Williams University (established, 1926) were primarily local, undergraduate teaching institutions, whereas McGill (established, 1821) was renowned for its undergraduate, graduate, and professional programs, and enjoyed a national and international reputation for teaching and research. All three accepted the German-American pattern of higher education, for which McGill earlier in the century had been a Canadian pioneer, and which called for a reformed liberal arts undergraduate program-humanities, social sciences, and science-superimposed upon which was a range of graduate and professional programs. That said, when the 1960s opened, Quebec's Anglophone universities like others across Canada, despite becoming more open and less elitist after World War II, were far from being democratic institutions of mass education. ${ }^{4}$

Quebec's solution to creating a higher education structure in line with contemporary practice of Anglophone Canada and the world, while paying homage to traditional Francophone educational heritage, was to create a unique blend of the two-borrowed and adapted from both sides. To begin with, Collegges classiques and their traditional curricula were swept away to be replaced during 1967/1969 by uniquely Quebec junior colleges, or CEGEPs, Collèges d'enseignement général et professionnel/Colleges of General and Professional Education. After finishing grade 11, both Anglophone and Francophone students would now proceed to these new institutions, granting diplomas in a wide range of technical and semi-professional occupations. In addition, they provided a mandatory route for university entrance through successful completion of a 2 year academic program. Unless designated as private, they were secular and charged no tuition fees.

As for universities, in the late ' 60 s Francophone institutions adopted Anglophone practice, becoming secular and adopting the German-American pattern of higher education: newly introduced undergraduate streams superimposed upon which were graduate and professional programs. Some professional programs such as Medicine and Law would be required to accept a portion of their students directly from CEGEPs. In anticipation of significantly increased Francophone enrolment, Quebec initiated the Université du Québec (UQ) system (established, 1968) with branches across the province-the centrepiece being the establishment in 1969 of Université du Québec à Montréal (UQAM). For McGill and other Quebec universities, undergraduate degrees would become standardized as 3 year programs. Despite initial trepidation and uncertainty, shared equally by Anglophones and Francophones, adoption of the new structures and patterns proceeded smoothly and with relative calm. CEGEPs did, however, require creative solutions by the Anglophone community, which unlike the Francophone community, had no collèges classiques for quick and easy conversion to junior colleges. Unlike their sister Francophone institutions, McGill and the other Anglophone universities expected enrolment to remain level or even fall, due to demographic decline of the English-speaking community.

\section{McGill University}

For McGill, the decade opened in 1960 with justifiable concern about its place in the world, despite appearing strong and healthy on the surface. On the positive side, was its strong international, academic reputation and reasonable claim to being Quebec's and possibly also Canada's leading university - with graduate enrolment accounting for $12 \%$ of 8,000 students, research grants representing $20 \%$ of the annual budget, and $\mathrm{PhD}$ graduates constituting $25 \%$ of the Canadian total. Principal F. Cyril James (1903-1973), supported by a small cadre of secretaries and assistants, provided intelligent and competent one-man leadership for the University. Financial support from Montreal's Anglophone community was unwavering, and provincial government support was growing slowly but steadily.

There was, however, also cause for worry. In acknowledgement of the growing importance of higher education, sharp competition was rising across the country as most other provinces began supporting their universities much more generously than Quebec. McGill's physical plant was old and increasingly inadequate both in quality and quantity, and its salaries had not kept pace with the rest of the country so that in 1960 professors' pay ranked only $21^{\text {st }}$ among Canadian universities. In some quarters, the University was considered to have an inflated reputation far exceeding reality, in others it was dismissed as merely a training ground for Montreal's Anglophone business and social elite. A major problem was financial: the inability of traditional funding sources - fees, gifts, and endowments - to keep pace with expenditures. Because of a jurisdictional dispute between the province and Ottawa, Quebec's universities were prohibited from receiving higher education funds provided by the federal government.

In 1962, two significant events marked a turning point for McGill, one was local and the other of provincial and national significance. The latter event was a negotiated settlement between Ottawa and Quebec City over university funding, whereby federal money for universities instead of 
going directly to institutions would be funnelled through the province-eventually all provinces-and distributed according to its own standards. McGill received immediately a windfall of $\$ 5,866,378$-its share of federal funding withheld for ten years at Quebec City's insistence. With this money, along with greatly increased provincial operating and capital grants, plus continuing private support from alumni and friends, McGill embarked upon a concerted program of growth and enhancement. The local event was the retirement of long serving Principal Cyril James, and the succession of Rocke Robertson under whose patrician, energetic, and intelligent leadership McGill was transformed academically, geographically, administratively, constitutionally, and financially. His leadership also positioned McGill effectively in dealing with the social and political turmoil of the era.

Armed with its strong tradition of academic achievement, McGill began upgrading and strengthening every faculty and department. Established faculties such as Medicine and Arts \& Science were rejuvenated through revised curricula and the hiring of young faculty. Two new faculties were created through reconstituting existing departments: Education (1965) and Management (1968). Engineering continued a policy begun in the '50s of reorienting departments towards research. McGill University Press founded in 1961 and reorganized in 1968 as McGill-Queen's University Press - in partnership with Queen's University, Kingston, Ontario-immediately established a reputation for producing important and widely discussed books. Although enrolment had nearly doubled by 1970 to 14,500 , the University remained a medium-sized institution. As for the Faculty of Graduate Studies and Research, between 1960 and 1970, its enrolment doubled to $24 \%$ of the student body, and research grants rose by $6 \%$ to $26 \%$ of the total University budget, or $\$ 15.6 \mathrm{M}$. Although awarded $\mathrm{PhDs}$ declined from $25 \%$ to $11 \%$ of the Canadian total, McGill retained its status as one of the country's leading producers of doctorates. Despite also growing competition, McGill held its position remarkably well. Indicative of its support for Quebec's new educational structure, between 1969 and 1974 the University conducted on its Sherbrooke St. campus a CEGEP program. ${ }^{5}$

The geography of the Sherbrooke St. campus was reconfigured with a massive building program - continuing into the mid ' 70 s - that would accommodate teaching and research for decades to come. These projects overshadowed even McGill's pre-World War I building splurge. ${ }^{6}$ Among the new structures, additions to existing buildings, and major renovations, were:

Bishop Mountain

Hall and Gardner,

1962

McConnell, and

Molson Halls

(men's residences)

\begin{tabular}{ll}
1963 & $\begin{array}{l}\text { Roscoe Wing, Royal } \\
\text { Victoria College } \\
\text { (women's residence) }\end{array}$ \\
\hline \multirow{3}{*}{1965} & $\begin{array}{l}\text { Stephen Leacock } \\
\text { (Arts) } \\
\text { University Centre } \\
\text { (students) }\end{array}$ \\
\hline Arts Building \\
- significantly \\
remodeled \\
McIntyre (Medical \\
Sciences) \\
Otto Maass \\
(Chemistry) \\
Stewart (Biological \\
Sciences) \\
Pathology-new \\
wing
\end{tabular}

To facilitate and implement these academic and geographic changes, the University's administrative structure was expanded, centralized, and revamped at both the executive and bureaucratic levels beyond anything previously known, but without undermining McGill's reputation for lean and decentralized administration.The number of Vice-Principals was doubled from two to four. In addition to Macdonald College continuing to have a VP, there would now be three designated Vice-Principals: Academic, Administration, and Professional Faculties. A Director of Finance position was also created that in time would be raised to the rank of Vice-Principal. Opened in 1967, the F. Cyril James Administration building housed an emerging professional bureaucracy with University-wide employment classification grades and salary levels, along with career opportunities for 
non-academic administrative staff. New administrative units were created such as Information (1964), Personnel (1966), and Planning (1968). Indicative of the central role that computers and information technology would play at McGill and throughout society, in 1959 McGill acquired its first computer accompanied by strict warnings that it was to be the University's only computer! Overseeing this new technology three new units were created reporting to three separate Vice-Principals: (i) McGill Computing Centre in 1959 under VP Planning; (ii) Instructional Communication Centre in 1968 under VP Academic; and (iii) Management Information Systems in 1970 under VP Administration. ${ }^{7}$

A remaining question revolved around governance. How ought McGill-expanding rapidly and embracing mass education - to be governed? This question of authority within the University led to contentious debate-and even violence-as McGill felt its way through unchartered territory. Important inspiration for McGill and other Canadian universities came from the Duff-Berdabl Report (1966), sponsored jointly by the Association of Universities and Colleges of Canada (AUCC) and the Canadian Association of Universities of Teachers (CAUT). The Report recommended democratization of university structures through such things as admitting faculty and general public members onto boards of governors, and electing deans and departmental chairs for defined terms. Local encouragement came from a 1959 report by the McGill Association of University Teachers (MAUT) established in 1951 "to foster academic freedom, to involve the faculty in University activities and governance, and to improve the working conditions and salaries of teaching faculty and librarians". A 1966/67 joint Senate-Board committee report, implemented in September 1968, transformed both Board and Senate. Senate-with control and supervision over academic activities - was transformed from an appointed body of senior administrators and some academics to a body whose majority was now composed of academics elected by their peers, in addition to administrators, and governors' representatives. As for the Board of Governors - with final authority over administration and finance-its membership was widened to include elected senators, women, and representatives from diverse sectors of the community, along with traditional representatives of business and industry.

In short, McGill's governance and administration underwent a profound transformation from benevolent autocracy to collegiality. Faculty Councils and Departmental Meetings were established or reformed-to include all faculty members - with agendas, minutes, and formalized procedures. Deans and departmental chairs whose appointments had been solely at the discretion of the Principal usually until retirement or death, were now appointed for fixed terms of 3 to 5 years (renewable) on the recommendation of advisory committees. In his short term as Dean before becoming Principal, Robert Bell began the process of transforming the Faculty of Graduate Studies Council into a collegial body with representatives from virtually every academic department on campus.

Strangely enough, students were overlooked in these reforms even though Principal Robertson as early as 1963 had shared with colleagues insights about emerging American student radicalism. By 1965, McGill's enrolment had risen to 12,728 - with the greatest growth being in the Faculty of Arts and Science-and a "Code of Student Disciplinary Procedures" was adopted. That same year, the radical Students for a Democratic University (SDU) movement began gaining control of student government and publications, and goading the administration into public confrontation. In 1966 the Arts and Science Course Guide created a sensation with pointed evaluations and criticisms of teaching, leading to creation in 1969 of the University Centre for Teaching and Learning. Protests, including sit-ins of Board Meetings and academic departments, were mounted against fee increases, the Viet Nam war, formation of the Faculty of Management, and American military research funding for Engineering. Support and encouragement for these protests came in part from young, recently hired faculty particularly in Arts. In 1968, the McGill Reporter was established as a vehicle for disseminating the administrations viewpoint and posting notices, since the student-run McGill Daily (established, 1911) showed itself increasingly unwilling to fulfill this role.

One person to emerge with particular notoriety during this era was an undergraduate English student, John Fekete (BA'68, MA'69), who in 1967 issued the two most provocative $\mathrm{McG}$ ill publications of the decade. The first was a September $25^{\text {th }}$ report, to the Joint Board-Senate Committee on University government, urging enhanced student participation in all aspects of University life. The second was a November $3^{\text {rd }}$ McGill Daily article, which raised a huge public outcry for quoting parts of an infamous defamation concerning American president Lyndon B. Johnston's alleged, and vividly depicted, sexual indignity upon the body of his assassinated predecessor, John F. Kennedy. The two issues became inextricably intertwined and led to student rallies and occupation of the principal's office. Although Fekete met defeat on the necrophilia article-failing to win general student support and receiving a sharp reprimand from the Senate Discipline Committee-he did win his argument on the role of students in University life. The Joint Committee issued a persuasive report pointing out that students were a constituent element of the University and should therefore play a significant role in University governance-along with faculty, administration, and community representatives. As a result, in September 1968 students started being elected to Senate. Although student representation on the Board would be legislated only in the next decade, Senate made a point of electing student representatives to the Board. Over the next several years, student representation on Board and Senate committees as well as faculty and departmental 
decision-making bodies and their committees would become commonplace.

Although student and faculty agitation continued even after introduction of these reforms, 1968 would in retrospect be the high water point of radicalism. Despite procedural skirmishes at Senate and the Board, radical agendas were thereafter never seriously advanced. Replacement of benevolent autocracy by effective collegial structures had removed an irritant and potential flashpoint. Radical agendas in Arts/ Social Science departments tapered off noticeably with the dramatic upgrading of library facilities - hitherto a source of great frustration - when McLennan and the rebuilt Redpath Libraries opened in 1969/70. The Departments of Economics \& Political Science, and Sociology were notable exceptions with their confrontations over curriculum development, and hiring and firing of staff. In 1969, a breakaway group from MAUT formed the McGill Faculty Union (MFU) that was never able to fulfill its goal of unionizing professors and librarians. The patience, fortitude, and lack of arrogance of Principal Robertson in listening and not over reacting to goadings and upheavals proved to be the correct strategy. Unlike those universities that engaged in rear-guard battles against admitting faculty and students into the decisionmaking process, McGill established internal domestic peace early on, thereby avoiding prolonged internecine warfare. This achievement of internal domestic peace was fortunate given the powerful debate that would rage within Quebec during the coming years and decades over language of education, and funding for higher education - issues over which McGill had little or no control, but which would affect it profoundly.

\section{Funding for Higher Education}

Until the 1960s, government funding for higher education in Quebec was notoriously meager. Ninety years after McGill's founding, appeals for funding were finally heeded in 1911/12, when Quebec granted \$3,000 in support of teacher training. That same year, Ontario's grant to the University of Toronto was \$1M. By 1949, McGill's grant had risen to
$\$ 132,000$ annually, or $4 \%$ of the operating budget. In the 1940 s, grants from other provinces to their universities were approximately $40 \%$ of annual budgets. Between 1932 and 1949, McGill received provincial grants totalling $\$ 2,379,167$, whereas Université de Montréal received \$13,832,707, and Université Laval $\$ 5,408,262$, despite having a combined 1947/48 enrolment lower than McGill's 7,756. Separate provincial grants were made to collèges classiques, which operated effectively as the undergraduate faculties of arts for the three francophone universities to which most colleges were affiliated. By comparison, McGill received no grant to cover the cost of undergraduate education, as it was judged to be the equivalent of a classical college program! ${ }^{1}$

When, in the 1950s, Premier Duplessis prohibited McGill and other Quebec universities from accepting federal money, J. W. McConnell (1877-1963) - a senior member of the Board of Governors-cautioned against engaging in a constitutional and political confrontation with the wily Premier whose position was too strong to be resisted. McConnell used his considerable powers of persuasion to convince the Premier that Quebec would have to compensate for the loss of federal university funding by developing a provincial granting scheme for higher education. Between 1954 and 1957, the University received $\$ 750,000$ annually, rising to $\$ 1,832,900$ in 1960 . $^{10}$

With Quebec's Quiet Revolution of the 1960s, and settlement of the jurisdictional dispute with Ottawa, provincial support for university operating and capital budgets improved dramatically. The operating grants were, however, unpredictable, and even capricious from McGill's perspective. Between 1961/62 and 1964/65 per student grants for the three French-language universities increased from $\$ 977$ to $\$ 1,295$, or $33 \%$, but for the three Englishlanguage universities declined from $\$ 586$ to $\$ 522$, or $11 \%$. From 1961 to 1966 McGill's enrolment rose by 45\%, staff $59 \%$, and operating expenditures $80 \%$, but Quebec operating grants by only $45.3 \%$. Indeed annual operating grants declined from $37.5 \%$ to $32.3 \%$ of total expenditures. Comparison of provincial grants between 1960/61 and 1966/67 for Université de Montréal, Laval, and McGill are revealing:

\begin{tabular}{|l|l|l|l|l|}
\cline { 2 - 5 } \multicolumn{1}{l|}{} & $1960 / 61$ & $1966 / 67$ & $\$$ Increase & $\%$ Increase \\
\hline Montréal & $\$ 5,412,370$ & $\$ 16,697,000$ & $\$ 11,284,630$ & $208 \%$ \\
\hline Laval & $\$ 3,878,105$ & $\$ 13,268,500$ & $\$ 9,390,395$ & $242 \%$ \\
\hline McGill & $\$ 5,175,514$ & $\$ 7,619,000$ & $\$ 2,443,486$ & $47 \%$ \\
\hline
\end{tabular}


As a result, McGill's faculty salaries were relatively low, tuition fees became the highest in the country, and a financial campaign was launched to balance the budget. ${ }^{11}$

During a 1971 television interview, Quebec's first Minister of Education (1964-1966) Paul Gérin-Lajoie provided the following explanation of the situation:

"McGill University had had the advantage of getting a lot of money from private sources at a period when the business establishment in Montreal was entirely English-speaking or very predominantly Englishspeaking...So some compensation had to be made by the public authority, by the government...There was a formula established. It was not intended to discriminate against any universities, not against McGill more than against any other universities, but it was intended to take into account the private sources of money of the universities and since McGill was the one having such large sums of private sources as compared to other universities in the province, well McGill suffered."

(Transcription from videotaped interview with the Honourable Paul Gerin-Lajoie broadcast over CBC "Hourglass", February 23, 1971) ${ }^{12}$

Gérin-Lajoie had overlooked the fact that inadequate public funding throughout its history had left McGill with no alternative but to solicit private funds. Also overlooked, was that McGill along with other non-Roman Catholic Anglophone institutions did not receive the services of clergy whose financial compensation was significantly lower than that received by lay people.

In 1965 and 1968 the province agreed to longstanding requests by McGill and other provincial universities for intermediary bodies that would recommend financial grants and lessen the likelihood of political controversy and breaches of academic freedom. Two committees were established: (i) Commission de l'aide à l'enseignement universitaire/Finance Sub-committee on Operating Budgets and (ii) Sous-comité des budgets universitaires de fonctionnement/University Investments Sub-committee on Capital Expenditures. They were composed of representatives from the three English and three French-language universities plus representatives from Ėcole polythechnique and Ēcole des hautes études commerciales-in addition to high-ranking provincial civil servants, and chaired by Germain Gauthier, Directeur général, Direction générale de l'enseignement supérieur, Ministère de l'education/ Director General, Directorate of Higher Education, Department of Education. ${ }^{13}$

The Capital Expenditures Sub-committee worked reasonably well, despite university representatives being denied voting power and instances of the government overturning recommendations. Even so, McGill's massive building and renovation projects proceeded successfully, combing government grants with significant private benefactions-such as Isabella McLennan's bequest permitting construction of a new library building. Of the \$150M spent between 1960 and 1975, \$83M came from the government of Quebec, $\$ 57 \mathrm{M}$ from private sources (graduates, benefactors, and corporations) and $\$ 15.5 \mathrm{M}$ from the government of Canada. ${ }^{14}$

Much greater concern emerged, however, with the Committee on Operating Budgets-usually referred to as the Gauthier Committee. Although the committee made reasonable recommendations, the government would regularly alter them to serve its own political agenda-sometimes to McGill's advantage but usually not. On the one hand, the government would sometimes reverse its own decisions and admit its error, or sometimes provide additional support for such things as the University's CEGEP program. On the other hand, annual protests by McGill became the norm.

In 1966, McGill was penalized much more heavily than other universities when Quebec City reduced each university's grant by $71 / 2 \%$, calculated upon its "total anticipated expenditure" including money received either from outside research granting agencies or from endowments. As McGill received significant amounts from these sources, it was more severely penalized than other universities. To its credit, however, the government would largely reverse this decision. In 1968, McGill was penalized again by the government's decision to base increases upon projected increases in enrolment. In 1969, the government reversed Gauthier's recommendation and reduced total university grants by $3.9 \%$ with McGill's reduction being $11.7 \%$ or $\$ 2.97 \mathrm{M}$, later revised to $\$ 2.5 \mathrm{M}$ - more than the combined reductions sustained by all other Quebec universities and equal to McGill's investment income and donations. The official reason for McGill's reduction was for running a deficit the previous year and spending beyond its allowed ceiling for expenditures. What was particularly worrying was perstudent funding from all sources - grants, fees, endowments, and donations - now being less for English-language than for French-language universities: Laval \$2,242, Université de Montréal \$2,249, McGill \$1,356 and Sir George Williams $\$ 1,059.15$

Principal Robertson and his Executive Assistant, G. A. Grimson, identified five major arguments used against McGill that supported funding discrepancies, to which they also provided their rebuttals. ${ }^{16}$

First, "rattrapage" - "catch up" - funding was required by Francophone institutions, for which McGill should be prepared to sacrifice.

Although agreeing wholeheartedly that additional support for other universities was justified, McGill did not understand why it should be at the University's expense. Some observers commented 
on the thin line between "catching up" and "fattening up"!

Second, McGill was "scandalously" prosperous through the support of wealthy Anglophones.

Robertson and Grimson pointed to the major discrepancy in per student funding from all sources between McGill and Francophone universities.

Third, the University's deficits should be covered by liquidating its large endowment.

McGill pointed out that a relatively small proportion was unrestricted, whereas the bulk was restricted to producing income whose expenditure was legally limited to specific uses or activities. What universities really needed were incentives to increase efficiency and raise additional funds. If McGill had to liquidate its endowment, other universities should also have to do the same.

Fourth, McGill's education of students from outside the province should not be at Quebec's expense.

The majority-75\% - of McGill's students were from within the province, Robertson said, with only $10 \%$ from other provinces and 15\% from outside the country. Having foreign and out-of-province students was enriching for McGill and Quebec. Furthermore, Quebec should keep in mind the large number of its own students being educated in other provinces and countries.

Fifth, the University's research activities brought sufficient extra funding to cover its needs.

Robertson, himself a prominent researcher, was incensed by criticism of what he considered a core McGill value and strength. Far from bringing additional financial support to the University, research entailed additional costs. Of the $\$ 10,894,226$ in $1965 / 66$ research grants, only $1.8 \%$ or $\$ 193,150$ was designated for overhead operating costs.

In dealing with Quebec City and its bureaucracy the art of negotiation was mastered slowly through trial and error, employing a combination of quiet diplomacy and public confrontation. In private meetings with Premiers Lesage, Johnson, and Bertrand and their advisors, Principal Robertson and his advisors found themselves constantly at a disadvantage. The government's position was characterized by cordiality, sincere regret at funding discrepancies, assurances of future improvement, and a desire to avoid public controversy. The University, for its part was constantly having to correct misunderstanding and misrepresentation about its financial reality and legitimate needs. ${ }^{17}$

One example was an urban myth suggesting that McGill possessed secret caches of money above and beyond those reported in its financial statements, and therefore didn't deserve government support, which the University tried to counter through private diplomacy. The situation came to a head in February 1968 when a confidential report leaked to the French-language press suggested that McGill's grant would be greatly increased. In response, a few weeks later Quebec's three English-language universities-McGill, Bishop's and Sir George Williams-made public what they considered discriminatory and unjust treatment. Principal Robertson was immediately rebuked by the Minister of Education, Jean-Guy Cardinal, for breaching confidentiality. The minister held that

"...one of the basic conditions for maintaining good relationships between the universities and the Department of Education should be to observe the rules that have been mutually agreed upon."

Press reaction to the plight of $\mathrm{McG}$ ill and the other English language universities was international, national, and provincial. Of particular interest was Vincent Prince's editorial in Montreal's French-language newspaper of elite opinion, Le Devoir. Although conceding that the claims of McGill and the other Anglophone universities had some justification, Prince went on to argue the importance of "rattrapage" for Francophone universities in raising their standards and ability to serve Quebec's majority community. While the Anglophone community accounted for only 13\% of the province's population-bolstered to $20 \%$ with NeoCanadian Anglophones not of English/British ethnicity or descent-it accounted for $40 \%$ of university enrolment. For English-language universities to receive, therefore, $30 \%$ of provincial grants, was a reasonable compromise, as was deducting gifts and endowment income from their grants. Francophone institutions had to be strengthened and expanded to ensure that they attracted both a higher proportion of Quebec's French-speaking population and also more foreign and out-of-province students.

Overlooked in Prince's analysis was how the Anglophone tradition of undergraduate streams had resulted in proportionally higher enrolment at the university level, whereas the Francophone tradition of not having undergraduate university streams resulted in high collège classique enrolment. Within one year, however, phasing out of the collèges was completed, and CEGEP graduates began flowing into newly created undergraduate programs. Francophone universities, bolstered by the Université du Québec system, would experience surging enrolment that would far surpass Anglophone enrolment, both absolutely and proportionally. Nevertheless attitudes, perceptions, and funding precedents - frequently disadvantageous to McGill-were established that would continue into the 2000s. ${ }^{18}$ 


\section{Language of Education}

When the decade opened, language of education in Quebec continued to be, as had long been the case, a personal choice with the decision determined largely by religion: Francophones attending Catholic schools and Anglophones attending Protestant schools. Exceptions were of no particular concern until the post World War II era when mass education came to Quebec along with large numbers of immigrants - many of whom were Roman Catholic who preferred, or were encouraged, to attend English-language schools; impediments to attending French-language schools were often encountered. As a result, the Protestant system and the English-language sector of the otherwise Frenchlanguage Roman Catholic system began expanding. As the 1960s progressed, however, concern for survival of the province's Francophone majority and Quebec's status in Canada became fused with the issue of language of education. A public dispute erupted over plans to provide Englishlanguage Roman Catholic education to children of Italian immigrants and their descendents living in the Montreal suburb of St. Leonard. Highly vocal groups advocated that "neo-Canadians" be required to attend French-language schools; others advocated the complete elimination of English-language education from the province. Provincial Bill 85 meant to settle this issue by emphasizing "French as Quebec's priority language while pressing individual linguistic freedom of choice in Education" was withdrawn in the face of nationalist opposition. In 1969, Bill 63, passed over strong opposition, asserted priority of French but permitted parents to choose whether their children would be educated in French or English. By now, language had emerged as a major issue across Canada, leading to the recommendations of the (Laurendeau-Dunton) Royal Commission on Bilingualism and Biculturalism, being embodied by Parliament in the 1969 Official Languages Act, whereby both English and French had equal status as national languages. ${ }^{19}$

\section{Opération McGill Français}

On Friday March 28, 1969, funding for higher education and language of education merged as a single issue that came crashing down upon McGill, when 10,000 chanting demonstrators participated in a "manifestation" on Sherbrooke St. outside the Roddick Gates-Opération McGill français. This remarkable event stands as a defining moment in McGill-Quebec relations, and was unprecedented in the history of Quebec/Canadian higher education. The immediate issue precipitating the manifestation was a widespread misperception-only slowly corrected by politicians and officials - that 10,000 francophone graduates from newly created CEGEP would be excluded in the autumn from higher education due to insufficient space in Frenchlanguage universities. Despite undergraduate programs developing on schedule at Montréal, Laval, and Sherbrooke as well as at the newly formed Université du Québec, radical voices urged that McGill be transformed into a Frenchlanguage university to handle the perceived shortage of student spaces. In addition, McGill was called upon to lower its academic entrance standards and permit public access to its library, the largest in Quebec.

Fringe elements advocating violence, such as le Front de liberation du Québec (FLQ) blended in with left wing groups such as le Comité Indepéndence-Socialisme (CIS), and sought to exploit the issue to their advantage-urging physical destruction of McGill as a way of cleansing Anglophone capitalism and colonialism from Quebec. McGill was characterized, and even demonized, as the embodiment of Anglophone capitalist owners dominating oppressed Francophone workers. Explicit threats of violence caused deep alarm, and led to evacuation of students, staff, and faculty from the campus, which was protected by a small band of officials and police.

Fear that McGill français might lead to serious violence is not surprising given the tenor of the times. In 1968, student demonstrations precipitated the resignation of France's President Charles de Gaulle. The same year, American President Lyndon B. Johnson-bowing to widespread public demonstrations-decided not to seek a second term; Rev. Martin Luther King Jr. and Senator Robert Kennedy were assassinated. In Montreal, where random terrorist bombs had detonated throughout the decade, Pierre Eliot Trudeau - recently become Prime Minister of Canada - was the focus of violent rioting during the June 24 St. Jean Baptiste parade. CEGEP students had paralyzed the system during an October 1968 strike. That December, the McGill Computer Data Centre was occupied by le Mouvement pour l'intégration scolaire, whose supporters chanted "McGill en français.". ${ }^{\prime 2}$ February 1969 saw radical students seizing and destroying the computer facilities at Sir George Williams University over a charge of racism.

In the end, the chanting McGill francais crowd caused little or no damage. Many participants were merely sightseers wanting to participate in a drama. When the riot police began dispersal operations around 11:00 pm, aside from a few minor incidents, people left quickly and quietly. Last minute assurances by education officials that sufficient space would be available in September at Francophone universities did much to ease the situation. The situation may also have been eased by a tacit recognition among the throng, and Franco-Quebec society generally, that modernization of Francophone universities was based upon an Anglophone Canadian/Quebec model. Destroying McGill would have reflected badly upon Quebec, and deprived it of an important role model. Having McGill function as a Quebec university was more important than having it operate in French.

Reaction to Opération McGill français was mixed. The English-language community was generally critical, although 
there were pockets of support-primarily among radical groups. Within Quebec's Francophone community, criticism was muted with some political leaders being publicly critical but privately supportive. Quebec's French-language newspaper of elite opinion, Le Devoir, and its editor Claude Ryan-future leader of the Provincial Liberal Party and Minister of Education - took a widely supported position: condemning violence and supporting the legitimacy of English-language education within Quebec, while also arguing that McGill received more than its fair share of financial support. Inspired by McGill's Professor Laurier LaPierre, Ryan declared that McGill, "Celui-ci souhait qu'en plus dêtre au Québec, McGill soit aussi du Québec" - McGill must cease simply operating in Quebec but must become fully part of Quebec. ${ }^{21}$

Within McGill, there was also a range of reaction. The Students' Society of McGill University opposed the Opération, but a Political Science lecturer-Stanley Gray-became a major supporter and spokesman, which contributed to his dismissal after a lengthy public hearing. In fact, McGill had changed and accommodated itself during the '60s to Quebec's changing realities. In 1963 there were introduced: staff French language courses, and the French Canada Studies Program, expanded right of students to submit written work in French, and a policy of admitting larger numbers of Francophone students. In 1968, McGill established "A Committee on Translation and Language Use Problems". Even so, by 1970 only $10 \%$ of the student body was Francophone, and no francophone could be found among the Principal, Vice-Principals, Deans, and members of the Board of Governors. Among the administrative staff, Francophones accounted for $3.4 \%$, and bilingual staff for $23.4 \%$ of the total.

Following the events of March 28, there was struck "The Committee on the Use of French at McGill" whose report was summarized as follows: ${ }^{22}$

While the subcommittee's inability to present a language policy indirectly supports the status quo, the report does contain various proposals designed to increase the use of French within the Roddick Gates and to make the environment more comfortable for the French Canadian pursuing his studies at the University. The committee urges that:

All Administrators above the level of department chairman should be capable of understanding French and speaking a "tolerable" French;

Each office have one member of the clerical staff who possesses a good level of proficiency in French;

Public relations work be carried out in both languages;

Students be permitted to write term papers in French when such work constitutes a major portion of their final mark;
Development of language courses for both students and staff at the least possible cost to those taking the courses".

\section{Conclusion}

Crisis and achievement characterized the 1960s and Rocke Robertson's principalship of McGill University. His achievements included using newly available resources to construct and renovate much needed facilities, and rejuvenate teaching and research programs. Growing enrolment was accepted as McGill's contribution to the demands of mass education. Bureaucratic and administrative structures were created, reorganized, and strengthened to meet the requirements of growth and complexity. Governance was restructured along collegial lines to ensure that faculty, staff, students, and the larger public participated in decisionmaking. Adaptation to Quebec's changing linguistic and political realities occurred rationally and deliberately through offering a CEGEP program, and increasing bilingualism. In the face of strongly emerging competition, the University retained and strengthened its position as a leading Canadian and international university.

Crises accompanied all these activities and events, as change and innovation proved both invigorating and disruptive. Internally the Sherbrooke St. campus became a virtual construction site, with attendant dislocation. Newly hired professors and revised curricula raised hackles among the faculty, as familiar faces and classes disappeared and new ideas and programs emerged. Bureaucracy and administrators aroused academic irritation and antipathy. Although governance was revamped with remarkable ease, its prelude involved significant faculty agitation, and student protest-even violence that resulted in the RCMP labeling McGill a hotbed of radicalism. Externally, provincial funding for McGill emerged as a politicized issue surrounded by uncertainty and insecurity, as did language of education. Combined, the two issues - language and funding - resulted in the greatest threat ever faced by the University: Opération McGill francais. Violence and threats of violence were etched into McGill's psyche, leaving a residue of trepidation and wariness that would linger well beyond the ' $60 \mathrm{~s}$.

Perhaps McGill's greatest achievement of the decade was undergoing fundamental change and reorganization while avoiding internecine warfare. In laying the foundation for internal social peace the University was able to focus, over the coming decades, upon its primary academic mission, teaching and research, attracting quality students, and finding the resources to fund these activities. As it left the ' $60 \mathrm{~s}$ and entered the 1970s, welcoming a new principal, McGill faced numerous challenges and opportunities:

1. Reconciling its national and international reputation for academic achievement with the demands of mass education; 
2. Pondering the source of student enrolment in the face of Quebec's demographically declining Englishlanguage community;

3. Determining its role within Quebec's new system of higher education, including CEGEPs;

4. Gauging the impact on higher education of Quebec's newly emerging focus upon priority for the French language;

5. Ensuring financial viability in light of provincial funding priorities;

6. Observing the effectiveness of newly created administrative and bureaucratic structures;

7. Monitoring the effectiveness of collegial governance systems in providing a sense of community and unity of purpose required to avoid internecine warfare, and

8. Facing effectively the challenge of producing academic excellence within a volatile and unpredictable environment.

\section{ENDNOTES}

${ }^{1}$ Board of Governors. Confidential Minutes. June 25, 1970. Document 58A

${ }^{2}$ The following provide background for this chapter:

Michael D. Behiels, Quebec since 1945. Toronto, Copp Clark, 1987; Alain Gagnon, et al. Quebec: beyond the Quiet Revolution. Scarborough, Nelson, 1990; Peter Gossage, An Illustrated History of Quebec: Tradition E Modernity. Toronto, OUP, 2012; Paul-André Linteau, Quebec since 1930. Toronto, Lorimer, 1991; Sean Mills, The Empire Within: Postcolonial Thought and Political Activism in Sixties Montreal. Montreal, McGill-Queen's, 2010; Desmond Morton, A Short History of Canada. $6^{\text {th }}$ ed. Toronto, McClelland \& Stewart, 2006; H. V. Nelles, A Little History of Canada. $2^{\text {nd }}$ ed. Toronto, OUP, 2011; Brian Young, A Short History of Quebec. $4^{\text {th }}$ ed. Montreal, McGill-Queen's, 2008.

${ }^{3}$ Claude Galarneau, Les collèges classiques au Canada français [1620-1970]. Montréal, Fides, 1978; Sidney M. Gershberg, "Pressure Group Politics; the Case of the Federation of Classical Colleges". McGill University, MA Thesis (Economics and Political Science) 1968; Magnuson, Roger P. The Two Worlds of Quebec Education during the Traditional Era, 1760-1940. London, ON, Althouse Pr, 2008. Chapters 6, 10; Report of the Royal Commission of Inquiry on Education in the Province of Québec. Quebec, The Commission, 1963-[67]. 3 pts. in 5 and index. (Part Two A, p. 196-209); "Subcommittee on University Operating Expenditures, the 'Collegial' level, a position paper by S. Frankel" May 30, 1967. RG3, c52, file 873.

${ }^{4}$ Robin Harris, A History of Higher Education in Canada, 1663-1960. Toronto, U of T Pr, 1976. p. 454-464.

${ }^{5}$ Stanley Brice Frost, McGill University: for the Advancement of Learning. Montreal, McGill-Queen's, 1984. v. II, Chapter 14; "McGill University Response to the 'Orientations' Questionnaire of the Council of Universities." June 1971. RG3, c105, file 1696, p. 2-3.

${ }^{6}$ MacKay L. Smith, Memories and Profiles of McGill University: Downtown Campus, 1798-2009. Montreal, Infinitebooks, 2009. Chapters 7, 8, 9.

${ }^{7}$ Frost, McGill University, II, p. 435-9.

${ }^{8}$ Frost, McGill University. II, Chapter 15; McGill Association of University Teachers. Website. [http://maut.mcgill.ca/] October 1, 2009; University
Government in Canada: Report of a Commission Sponsored by the Canadian Association of University Teachers and the Association of Universities and Colleges of Canada. Commission: Sir James Duff, Robert O. Berdahl. Toronto, Published for the Associations by University of Toronto Press, 1966.

9"Report to the Faculty by Dr. H. Rocke Robertson, Principal and ViceChancellor, December 12, 1966, RG3, c52, file873, p. 3, Appendix 4, "Exclusive of Expenditures on...Agriculture, Household Science, and the Training of Teachers...Exclusive of Grants to the Classical Colleges... faculties of Arts...Laval and Montreal"; Gwendoline Pilkington, Speaking With One Voice: Universities in Dialogue with Government. Montreal, History of McGill Project, McGill University, 1983. chapters III, IV, \& V.

${ }^{10}$ William Fong, J. W.McConnell: Financier, Philanthropist, Patriot. Montreal, McGill-Queen's, 2008. Chapter 17. Frost, McGill University. II, p. 251-253.

${ }_{11}$ "Quebec government grants to universities and classical colleges (as reported in Public Accounts and Budget Estimates) A. C. M. 16/2/66. Statements 1-6". RG3, c52, file877; "Report to the Faculty by Dr. R. H. Robertson, Principal and Vice-chancellor, Monday December 12, 1966" RG3, c52, file873.

12"Memorandum on McGill's Financial Situation." August, 1971. RG3, c327, file 7800 .

${ }^{13}$ "Quebec government grants to universities and classical colleges. Statement 2" RG3, c52, file877; "Translation of a letter...to...L A Vachon... by Jean-Guy Cardinal" February 28, 1968. RG3, c52, file874; "University Grants Commission." RG2, c269. file8110; Montreal Gazette July 22, 1960, p. 1; "Grants: Provincial Grants: Quebec University Grants Commission" RG2, c269, files 8110, 8114 .

${ }^{14}$ Frost, McGill University. II, p. 432; G. A. Grimson letter to Pierre-Paul Proulx, June 19, 1969. RG2, c354, file13095; Peter F. McNally, "McLennan Library: Twenty-Fifth Anniversary." Fontanus: from the Collections of McGill University, v. VII (1994), p. 152-155.

15"Notes on Allocation of Grants 1966-67" December, 1966; "Meeting with Hon. P. Dozois" January 17, 1967; "Report of Sub-committee on Operating Budgets, 1967-68, General Comments, McGill University. January 23, 1967. RG3, c52, file 873. "Discussions with Mr. Johnson-March 13, 1968" RG3, c52, file 875 .

16"Report to the Faculty by Dr. R. H. Robertson, Principal and Vicechancellor, Monday December 12, 1966" RG3, c52, file873; "Some Notes by Dr. H. Rocke Robertson on Rattrapage” 29 December, 1967. RG3, c52, file878; "Comments on the Experience of the Sub-Committee on Operating Budgets (Gauthier Committee) circa 1969. RG2, c354, file13095.

${ }^{17}$ "Memo on Meeting with Prime Minister Daniel Johnson, Chancellor and later M. Jean-Guy Cardinal and M. Marcel Faribault, 14 Mar/68". RG3, c52, file874; "Discussion with Mr. Johnson, March 13, 1968; "Memorandum for interview with Prime Minister Jean-Jacques Bertrand, 28 April, 1969” RG3, c52, file875.

${ }^{18}$ Lysiane Gagnon, "Nouveau bond gigantesque en 1968 des subventions accordé à McGill." La Presse, fev. 10, 1968, p. 1-2. "McGill, Sir George, Bishop's Protest '68-'69 Operating Grants." Mc Gill Bulletin, no. 15, April 15, 1968, RG3, c52, file874; Letter from Cardinal to Robertson, April 3, 1968. RG3, c52, file1874; Vincent Prince, "L'universités anglophones du Québec sont-elles victimes d'une injustice?” Le Devoir, avril 1, 1968, editorial page; See also newspaper clippings in RG3, c327, file7800.

${ }^{19}$ Marc V. Levine, The Reconquest of Montreal: Language Policy and Social Change in a Bilingual City. Philadelphia, Temple University Press, 1990. Chapter 4.

${ }^{20}$ Frost, McGill University. II, p. 458.

21"McGill français: 30 ans après." Cahiers du PEEQ [Programme d'études sur le Québec], no. 20, janvier, 2001. (Claude Ryan, "McGill français: 30 ans après." p. 17-20)

22"McGill français: 30 ans après." (Ginette Lamontagne, "McGill et le fait français de 1969 à 1999: de la coexistence à la francophilie." p. 23-28) 



\title{
A Brief History of MUNASA: McGill Non-Academic Staff Association
}

\section{by Gordon Burr}

\begin{abstract}
MUNASA is a voluntary organization created to represent all McGill University non-academic staff in 1972. After gaining recognition from the University it negotiated many major policies for McGill employees including Summer Friday vacations and greater rights for causal employees. When many McGill employees (clerical, library assistants and technical staff) decided to form a union, MUNASA reconstituted itself in 1995 as a voluntary organization for management staff. This paper began as a talk to commemorate the 40th Anniversary of MUNASA on June $12^{\text {th }} 2012$ at the meeting of CACPUQ held at the Macdonald Campus of McGill University.
\end{abstract}

\section{RESUMÉ}

Créé en 1972, MUNASA est une organisation bénévole, non affiliée et non syndiquée qui représente les gestionnaires, les techniciens et le personnel de bureau et les employés des bibliothèques de l'Université McGill. Après avoir acquis la reconnaissance de l'Université, MUNASA a réussi à négocier des politiques pour les employés et le personnel non enseignant incluant la politique d’obtention de congés les vendredis matin pendant l'été au lieu d'avoir une augmentation salariale ainsi que la nouvelle politique pour les droits du personnel temporaire. En 1995, la création du syndicat MUNACA a eu pour conséquence la perte des employés de bureau, des techniciens et des employés de la bibliothèque au sein de MUNASA. La seule catégorie d'employé restante était celle de la gestion. MUNASA a réussi à garder son rôle en s'affirmant lors des discussions avec l'Université sur les politiques concernant les gestionnaires. Ce document est un discours qui fut présentéle 12 juin 2012 lors de la réunion du CACPUQ au campus Macdonald de l'Université McGill pour la célébration du 40e anniversaire de MUNASA.

\section{Background}

$\mathrm{M}$ cGill University has a reputation in Quebec as being a bastion of Anglo- Saxon Protestant elitism. ${ }^{1}$ This idea, when coupled with the close association of the University since the $19^{\text {th }}$ century with such wealthy Anglo leaders of the Montreal business community as Lord Strathcona, William Macdonald, Edward Beatty and J.W. McConnell, reinforced the idea of the University as a private entity removed from public scrutiny. By the 1970's this conception of McGill was only a myth. The reality was very different. The Anglo business elite was in decline, ${ }^{2}$ language legislation was in place to promote the use of French in the workplace, the student revolt had led to the opening of University governance to not only students, but to academic staff and even non-academic staff. By 1978 Stanley Frost, the university historian could declare that McGill was a "secular, cosmopolitan university in the Canadian tradition" and with government funding McGill was no longer a private institution. ${ }^{3}$

\section{Quiet Revolution}

The Montreal anglophone community's isolationist attitude concerning the Francophone majority of Quebec society had been under review since the advent of the Quiet Revolution in the early 1960's. The rise of new state run bureaucratic structures and the attendant regulations made the more informal decision making structures of the anglophone community seem out of date and irrelevant. ${ }^{4}$ The inclusion of more groups in the societal power structures, growth of government funding along with unions and employee associations led to changes in the internal dynamic of Quebec universities including McGill.

These changes in Quebec society were absorbed only gradually and piecemeal into the McGill milieu. The creation of an association to represent employees is but one reflection of how these societal trends played out in the specific context of the workplace culture of McGill. In the McGill context the loyalty of employees to the University, the perceived need to collectively defend the rights of non-academic staff and an external push for unionization on the campus were the three 
most important influences on the creation of MUNASA (McGill University Non-Academic Staff Association). The establishment of a McGill oriented employee organization was also encouraged by the Vice-Principal responsible for the administrative services of the University, Stanley Frost. Frost felt that this alliance of non-academic staff was required to ensure balanced, effective negotiations by the University with all employee groups on salary and benefits. Otherwise faculty, through MAUT, and unionized staff, through their unions, would emerge with the bulk of salary and benefits. ${ }^{5}$

\section{Frustrations of McGill Employees}

By the early 1970's frustration was mounting amongst nonacademic staff over the lack of a meaningful dialogue with the senior administration. Many non-academics lamented the senior administration's paternalistic approach of frequently enacting policies without consultation from the very people (non-academic staff) who were expected to implement them. ${ }^{6}$

\section{Loyalty to McGill}

In a 1974 interview, McGill Principal Robert Bell was asked why non-academics came to work at McGill. Bell responded quite frankly that he felt one of the main reasons was a more fulfilling working environment then in industry. A noteworthy element in Bell's response is his acknowledgment of the unique work environment of a University where teaching and research were conducted to improve societal knowledge. This view shared by many McGill employees evoked a very strong sense of loyalty to the University.

Into this particular collegial environment lacking any structured voice for employee groups, the collective voice of MUNASA was born. A group of managers set out to create an association to represent the interests of all non-academic employees whether managers or clerical or technical staff. ${ }^{8}$ The goals were to achieve recognition as the official representative of its members and to better the conditions of the non-academic staff. ${ }^{9}$

\section{Birth of MUNASA}

MUNASA (McGill Non-Academic Staff Association) was founded at 6:10 P.M. on November 30, 1972. The nine founding members, mostly managers, were Jim McVety, Stu Budden, Ed DesRosiers, Louise Biernaski, Ray Bartschat, George Franks, Derek Remsen, Leo Kerklaan and J.P. Schuller. The interim executive was selected at this meeting with Stu Budden as Chair and Jim McVety as Secretary. Membership would be open to all non-academic staff that were either not represented by other staff associations or not included in collective agreements.

Six days later, on December 6 1972, the first general meeting was held with an attendance of two hundred and sixty employees. Stu Budden addressed this meeting and discussed some of the particularities of working at McGill University for the non-academic staff. He depicted the University as distinctly different from industry. The McGill environment, he mentioned, dedicated to the education of students engendered great devotion to the job and a strong sense of community. He contended that managers, technical and clerical staff could often be at cross purposes in their work roles but could unite on issues of fringe benefits and working conditions to the betterment of all concerned.

The conflicting workplace interests of technical, clerical and middle management staff could be reconciled, he argued, if the focus was on proceeding in a cautious, rationale manner where the common interests such as benefits were stressed and everyone's voice could be heard in the structured consultative process. Budden's mantra for MUNASA was "there are no bosses in the organization just members" ${ }^{10}$. He argued that there exists a mutual "interdependence" between students, academics, non-academics and administrators. Therefore, the non-academic employees should have an input into decisions of the university since they will be affected by any decisions made." ${ }^{\prime 1}$

The intention was to create a voluntary, unaffiliated, nonunion organization. The democratic nature of organization was also confirmed by Budden's promise that all of these other issues would be debated and ultimately determined by the majority of the membership under a constitution. ${ }^{12}$

\section{Governance}

The constitution and by-laws of MUNASA were approved at a SpecialGeneral Meeting on March 21,1973 with the election of officers occurring in April 1973. MUNASA consisted of councils representing different classifications of workers. The original councils were Technical, Clerical, Macdonald College (based on the distinct identity and location of this campus), and Management, with Library Assistants being added in 1975. The executive council consisted of President, Executive Vice-President, Vice President Liaison, Treasurer and Secretary as well as 7 representatives from the councils. ${ }^{13}$ The first president of MUNASA in 1973 was Stu Budden, a McGill accountant and a member of the M (Management) category.

Each council had independent authority to act for their particular members. This right was chiefly exercised in the area of grievances. The potential conflict of management and clerical employees was assuaged through this approach. In order to have a balance of interests on the executive and reflect the relative number of members within the councils the clerical and technical councils were entitled to two members each on the executive with the remaining three councils having a single member. The 5 officers were elected from all the members in order to ensure that no one council or group could control the organization. ${ }^{14}$ 


\section{Progress in employee policies and recognition by the University}

In 1974 MUNASA participated in various processes to improve the voice of non-academic staff of the University. Jim McVety reported in June 1974 that MUNASA would appoint members to an electoral college based on their membership numbers to vote on non-academic members to the Board of Governors and the Pensions committee. ${ }^{15}$

During that same year MUNASA struck a personnel policy review standing committee. This committee's goal was to investigate policies in the areas of salaries, job classifications, educational opportunity, seniority, promotion and job security. In the committee's December report MUNASA asked the University to provide free tuition for McGill employees taking McGill courses and stressed the necessity of providing free staff French language courses to all McGill staff citing the then recent language legislation. ${ }^{16}$ The staff French courses also provided an opportunity for members from different offices and job categories to meet in a work related yet informal setting. Typically they were 2 hours per week; most people used one hour of work time and one hour of their own time.

The second President of MUNASA, Ida Godefroy, in her President's report for 1974 proclaimed that in the second year of its existence the association had made significant contact with the administration on a variety of issues and in her words "we can say with confidence that major decisions which effect affect us will no longer, as they were in the past, be decided without our views being sought out and listened to attentively."17

\section{The Union debate of 1974-75}

The liveliest debate in 1974-75 centred on whether MUNASA should become a union. The decision recorded in the minutes of the Annual Meeting from January 28, 1975 was a resounding no. ${ }^{18}$ For Godefroy the advantages of an association included membership across all sectors of the university including managers and supervisors, lower costs to employees and the flexibility to open negotiations at any time on issues. The chief disadvantages were no legal strike status, no strike fund, and no signed contract. ${ }^{19}$

In 1975 the third president Dave Stephenson, a medical technician, gave as the rationale for MUNASA that it was "the only way that the administrative body of McGill can get a collective opinion from non-academics.20 He clearly preferred an association to a union citing reasons such as greater flexibility and less confrontational stances. ${ }^{21}$

\section{Policy Gains}

By 1976 MUNSA claimed the following policy gains on the part of its membership: better salaries including cost of living adjustments, education plan and on-campus health care $e^{22}$ along with the establishment of a grievance procedure with an external arbitrator moving away from the older practice of having the Principal decide as the court of last resort. ${ }^{23}$

\section{Employment Security}

In 1976 MUNASA achieved an employment security policy based on three years of service with guarantees that the employee had a right to another position at the same level of salary and classification until a new position was found. ${ }^{24}$ President Stevenson viewed this agreement that drew upon the experience of a similar policy at the Université de Montreal as a major accomplishment of MUNASA. The rationale for this policy was that MUNASA members' preferred economic security over generous lay off packages. ${ }^{25}$

\section{Parity}

A parity agreement signed in 1976 on June $9^{\text {th }}$ with the University acknowledged the principle of "equal pay for equal work". This included all non-academic employees not covered by other agreements. The new scales for clerical and library staff based on scales at the Université de Montréal meant that most McGill employees would receive increased salaries. The University agreed to endeavour to adhere to the same principle for employees paid on research funds. ${ }^{26}$

By 1978 parity in the non-salary areas had been greatly enhanced through vacation entitlement becoming standardised at 4 weeks after 3 years of service and the introduction of two floating holidays. ${ }^{27} \mathrm{Jim}$ McVety, the chair of the MUNASA negotiating committee, reported that McGill had revised their vacation policies to bring them in line with similar policies at other Quebec Universities. ${ }^{28}$

\section{MUNASA in the Johnston era}

In February 1979, Allan Youster, president from 19781987, writing to Principal elect David Johnston spelled out the philosophy of the organization. It was a voluntary organization comprising 1300 members from a pool of 2100 . There was no legal status for the association and unlike most labour organizations in Quebec MUNASA sought a cooperative collegial relationship with the University and did not follow the adversarial approach of their colleagues at other institutions. "Our membership believes that that a functioning relationship built on this approach has to be healthier and more productive for both the University and the staff than the standard adversary approach commonly seen with unions" ${ }^{\prime 29}$ Johnston wrote back to support MUNASA stating that it "accords quite closely with my own view of government within the University."30

This type of approach is reflected later that year in the face of budget difficulties, Youster pledged to Vice Principal 
Finance John Armour that "MUNASA will be giving serious consideration to what it can do to help deal with the problem" to "bring about a renewed and strengthened spirit of cooperation between the various constituents of the University community." ${ }^{31}$ In a letter written to Principal Johnston, Youster offered to accept a $2.2 \%$ reduction in merit as long as MAUT (academic staff association) also limited the salary increases to the same level as MUNASA. ${ }^{32}$ In the same letter he sought to establish a sub-committee reporting to the Board of Governors to be responsible for the direction of salary and staff relations policies to match a similar committee for academic staff. ${ }^{33}$ This proposal led to the creation of the Non-Academic Salary Policy Committee in $1979 .{ }^{34}$

By 1976 McGill University through regulations that applied to all Quebec universities had reduced hours by giving Friday afternoons off in the summer between from June $24^{\text {th }}$ to the last work Friday before the Labour Day weekend. In 1981 responding to budget difficulties on the part of the University non-academic staff accepted in lieu of a merit increase to have Friday mornings off as well. ${ }^{35}$

In 1985 the Task Force on Finances created by the Board of Governors to advise the Principal concerning the deficit included a member from MUNASA. ${ }^{36}$ The McGill offer to employees that they accept $2.5 \%$ less in pay increases was controversial. ${ }^{37}$ However, the MUNASA executive recommended acceptance of the agreement arguing that for most McGill non-academic employees "involvement with McGill is not simply a job but is part of their life and McGill is not an employer but rather a community to which they belong."38 In the President's Annual Report of 1985 the deficit caused by the underfunding of the University had made regular pay increases problematic but the hope was that out of this crisis could emerge a greater feeling of team spirit to help improve employee morale. ${ }^{39}$

In his last presidential report (1987) Youster cited the successes of MUNASA in achieving improvement in policies such as employment security, grievance procedures, staffing policy, parental leaves policy and Summer Fridays. He also noted that negotiations on a casual employment policy had entered its sixth year with little headway being made. ${ }^{40} \mathrm{He}$ lauded the role that MUNASA played in helping the "second class citizens (of McGill who) get lost in the shuffle".

\section{Formulation of a casual payroll policy and the creation of MUNACA}

In 1988 Irene Tenant became the second woman president of MUNASA but served only a few months. She cited the creation of an Employee Assistance program as the main accomplishment during her tenure and called the presidency "an enlightening experience."41 Irene was succeeded as president in a by election in September 1988 by Trevor Garland. Trevor joined MUNASA in 1975 when he came to McGill, served as an M (Management) council representative for 5 years, then as an executive officer (vicepresident Liaison) from 1985-1988. Trevor presided over his first executive committee meeting on October 3, $1988^{42}$ and served as president until 2007.

The first major policy implementation for the new president was on casual policy. In 1989 the University agreed to the regularization of casual positions at McGill. MUNASA estimated that this could create 100 new regular positions. ${ }^{43}$ Casual employees received far fewer benefits than regular employees, often performing the same tasks as regular employees and sometimes holding the position for many years. ${ }^{44}$ They were not entitled to job security and were ineligible for pensions or the same vacation policy as full time McGill employees.

Under the new policy, casual employees who had worked at the same job for three years were eligible to have their position converted into a full time permanent one with the same rights as other non-academic employees. Regular employees who had been casual employees were eligible to have their period of casual employment added to the years of service for benefits such as vacation entitlement. The casual policy also limited the employment of casuals to leave

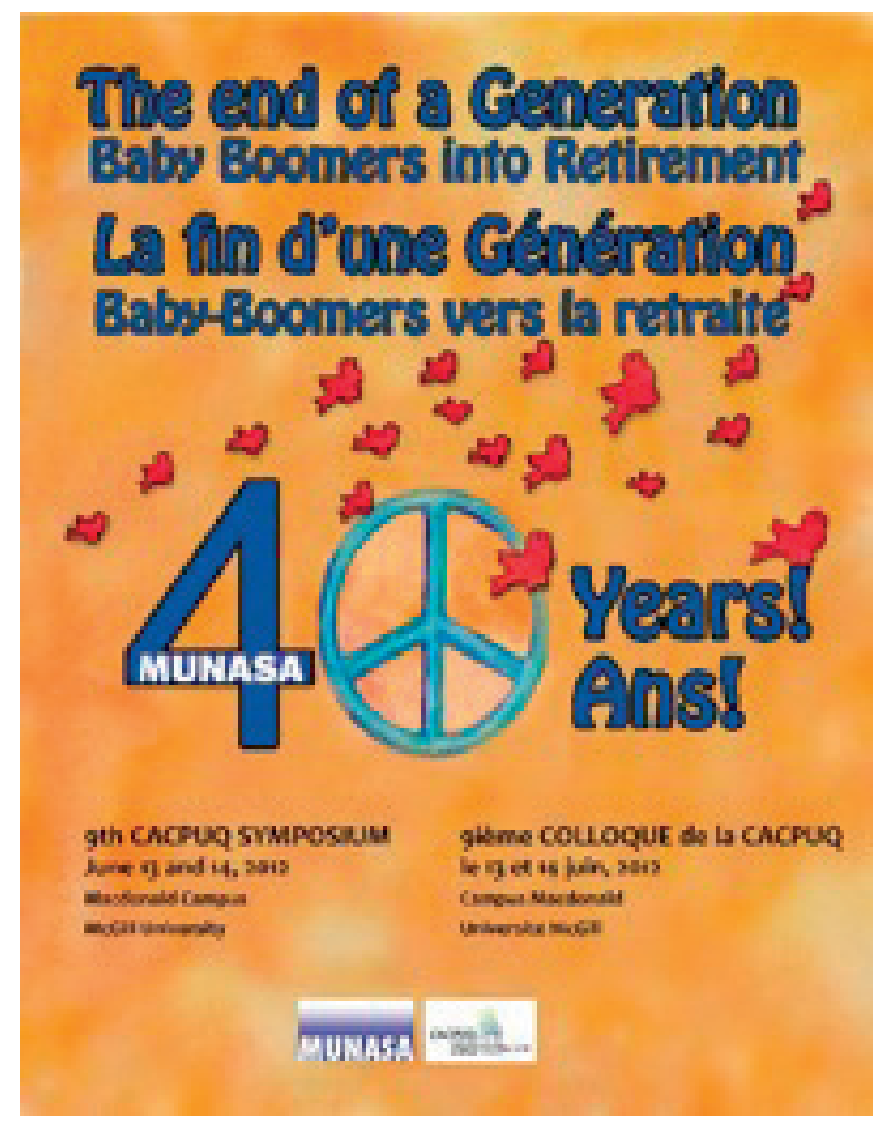

Celebration of the 40th Anniversary of MUNASA at the CACPUQ Conference on The End of a Generation : Baby Boomers into Retirement June 2012. From the website of MUNASA accessed June 29th, 2013 http://www.munasa.com/CACPUQ.html 
replacement, temporary replacements up to a maximum of 26 weeks, and excluded fulltime McGill students from the exigencies of this policy.45

The policy sparked controversy from the academic sector of the University due to the impact it might have over the employment of personnel in academic departments and in particular for those employees paid on research funds. Trevor Garland lamented “Don't academics have any respect for non-academics and the role we play in making McGill one of the best universities in the world?" ${ }^{46}$

\section{Changes in relations with the University}

By the early 1990's in an era of ongoing budgetary problems the role of MUNASA had evolved with an increasing focus as a representative of employee interests. This change is reflected in this quote from Trevor Garland in 1992 :

The simplest and most accurate description of our relations with the Administration is one word... Adversarial. ...That sounds bad, but actually it is good because it is clear. Our job in M.U.N.A.S.A. is labour relations, representing employees. In labour relations, the Administration represents the employer. Two very different things, quite opposite each other in fact. The employer concerns himself with what is best for the employer. The employee concerns himself with what is best for the employee. Reaching an agreement that bridges those opposing interests hopefully provides what is best for both.

\section{Post 1995-MUNASA survives}

By 1995 under pressure from years of budget cuts, nonmanagement staff at McGill turned to a union model to protect their collective rights. The creation of the MUNACA union in 1995 meant the loss of technicians, clerical staff and library assistants from MUNASA. The only remaining category was the $\mathrm{M}$ or management section. In 1995 the University ceased to recognize MUNASA as an entity and McGill sought to establish a new set of relationships with the managerial staff. Under challenge from the University ${ }^{47}$ MUNASA survived by legally reconstituting itself in 1995. It then participated in discussions over the following years with the University on a number of issues including the implementation of an $M$ Compensation system, performance planning, a merit based system and the creation of performance dialogue. MUNASA continues to defend the rights of its members through a revamped grievance process. ${ }^{48}$ The association has also participated in joint projects with the McGill Association of University Teachers on university governance and McGill unions including MUNACA on the issue of staff benefits.

\section{Conclusion}

The informal workplace style of McGill praised by Principal Bell in the 1970's, like that of most Universities, has been replaced in recent times by a more structured bureaucratic approach much closer to corporate or business models. The challenge for MUNASA under current president Ron Critchley remains, however, the same as the one originally pursued in 1972, finding ways to promote equity within the workplace.

\section{Appendix I-Presidents of MUNASA}

\begin{tabular}{l|l}
1973 & Stu Budden \\
1974 & Ida Godfrey \\
$1975-1978$ & David Stevenson \\
$1978-1988$ & Alan Youster \\
1988 & Irene Tennant \\
$1988-2007$ & Trevor Garland \\
2008 & Ronald Critchley
\end{tabular}

\section{ENDNOTES}

This is based on a talk given at $9^{\text {th }}$ CACPUQ Symposium, June $13^{\text {th }}, 2012$. Copies of some newsletters and other publications are in the McGill University Archives; most original records are held by MUNASA.

${ }^{1}$ Stanley Brice Frost. The History of McGill in Relation to Montreal and Quebec. La commission d'études sur les universités, 1978. p.9.

${ }^{2}$ Ronald Rudin. The forgotten Quebecers: A History of English Speaking Quebec, 1759-1980. p.213.

${ }^{3}$ Frost, Ibid.

${ }^{4}$ Sheila McLeod Arnopoulos and Dominque Clift, The English Fact in Quebec. Second Edition. 1984., p.104.

${ }^{5}$ Telephone interview with historian of McGill University, Peter McNally, May 17, 2012.

${ }^{6}$ MUNASAN Volume 5, Number 1, January/February 1977.

${ }^{7}$ MUNASAN Volume 2, Number 4, June 1974.

${ }^{8}$ MUNASAN Volume 5, Number 1, January/February 1977.

${ }^{9}$ MUNASA, Minutes, November 30, 1972.

${ }^{10}$ MUNASAN Volume 5 Number 7, November, December 1977.

${ }^{11}$ MUNASAN Volume 1, Number 1, May 1973.

${ }^{12}$ MUNASA, Minutes of First General Meeting, December 6, 1972.

${ }^{13}$ MUNASAN Volume 5, Number 7, November/December 1977.

${ }^{14}$ MUNASAN Volume 5, Number 7, November/December 1977.

${ }^{15}$ MUNASAN Volume 2, Number 4, June 1974.

${ }^{16}$ MUNASAN Volume 2, Number 8,November-December 1974.

${ }^{17}$ MUNASAN February, 1975 p.3.

${ }^{18}$ MUNASAN February, 1975 p.11.

${ }^{19}$ MUNASAN February, 1975 p.27.

${ }^{20}$ MUNASAN Volume 5, Number 4, January/February 1977.

${ }^{21}$ MUNASAN Volume 10, No.6, 1983 cites MUNASAN article reprinted from Volume 3, Number 1, 1975.

${ }^{22}$ MUNASA Brochure circulated April 1976.

${ }^{23}$ MUNASAN Volume 5, Number 1, January/February 1977. 
${ }^{24}$ MUNASAN Volume 4, Number 2, March 1976 p.13-14.

${ }^{25}$ MUNASAN Volume 6,Number 1 (Jan/Feb) 1978.

${ }^{26}$ Munasan extra issue, June 21, 1976.

${ }^{27}$ MUNASAN Volume 6,Number 1 (Jan/Feb) 1978.

${ }^{28}$ MUNASAN Volume 6, Number 3, April 1978.

${ }^{29}$ Letter Allan Youster to David L. Johnston, February 20, 1979. Outgoing executive correspondence Box 1 Comm1.1.

${ }^{30}$ Letter David L. Johnston to Allan Youster, February 26, 1979. Incoming executive correspondence Box 1 Comm1.1.

${ }^{31}$ Letter Allan Youster to John Armour, October 3, 1979. Outgoing executive correspondence Box 1 Comm1.1.

${ }^{32}$ Letter Allan Youster to David Johnston, October 15, 1979. Outgoing executive correspondence Box 1 Comm1.1.

${ }^{33}$ Letter Allan Youster to David Johnston, October 15, 1979. Outgoing executive correspondence Box 1 Comm1.1.

${ }^{34}$ Letter David L. Johnston to Letter Allan Youster, December 18, 1979. Incoming executive correspondence Box 1 Comm1.1.
${ }^{35}$ MUNASAN Volume 17, Number 7, October 1989.

${ }^{36}$ Letter David L. Johnston to Letter Allan Youster, January 23, 1985. Incoming executive correspondence Box 1 Comm1.1.

${ }^{37}$ Letter Allan Youster to David Johnston, November 27, 1981. Outgoing executive correspondence Box 1 Comm1.1.

${ }^{38}$ Letter David L. Johnston to Letter Allan Youster, November 19, 1981. Incoming executive correspondence Box 1 Comm1.1.

${ }^{39}$ MUNASAN, Volume13, no.1, March 1985.

${ }^{40}$ MUNASAN, Volume 16, Number 1, 1988.

${ }^{41}$ MUNASAN Volume 16, October 1988.

${ }^{42}$ MUNASAN, Volume 17, number 1, January 1989.

${ }^{43}$ MUNASAN Volume 17, number 7, October 1989.

${ }^{44}$ MUNASAN Volume 17, number 7, October 1989.

${ }^{45}$ MUNASAN Volume 17, Number 5, June 1989.

${ }^{46}$ MUNASAN Volume 17, Number 7, October 1989.

${ }^{47}$ Annual General Meeting_President's report-Jan. 25, 2008.

${ }^{48}$ Ibid. 


\section{Notes and Comments}





\section{Frank Scott's University of Dystopia, 1924}

\section{by Robert H. Michel}

A $s$ self-contained micro-societies, universities make ideal settings for dystopias and unpleasant visions of the future, whether the theme is social formation, sexual freedom, political slavery or debasement of learning. Yet while satires abound, for example those by Tom Sharpe, memorable dystopian fiction set in university or analogous settings is rarer: one thinks of John Barth's Giles Goat-Boy (1966) or the less ambitious yet striking No Transfer (1979) by Stephen Walton, where students with failing grades, including a girl fresh from lovemaking in her dorm, are selected randomly and guillotined.

In November 1924, law student (and future professor and poet) Frank Scott (BCL 1927) published a brief satirical story in the McGill Daily Literary Supplement about a futuristic university. An appropriate vehicle for satire, the Literary Supplement became one of the earliest forums for modernist Canadian poetry and prose as well as jabs against established social and university mores. The innocent inspiration for Scott's take-off was the University of Pittsburgh's recently projected "Cathedral of Learning," a skyscraper tower capable of housing an entire university. From the Cathedral, Scott extrapolated an invented university which was mildly but ominously prophetic of modern totalitarianism and computer technology in its use of automated tickets, indexes, reports and officials to track and control each minute and movement of a student's day. Newly-arrived McGill French professor Régis Messac later spoofed the Daily and student literary journals in Smith Conundrum, his satirical novel about McGill. He almost certainly would have read Scott's satire and been amused by Scott's visions of future automated student life; "American" universities' mindless efficiency and emphasis on bigness; the curriculum of subjects from Pragmatism to Propagandism; and the higher floors "nearest Heaven" which were "devoted to Theology, Clan Government and kindred topics." ${ }^{1}$ As Scott's fellow student writer Leon Edel (BA 1927, MA 1928) recalled, Scott's article, offered a "Wellsian peep at the future ... far ahead of Orwell."

In 1914, in his satirical novel Arcadian Adventures with the Idle Rich, Stephen Leacock had already postulated a 15 story skyscraper on his thinly disguised McGill campus. The public mistook the building for a factory since it had machinery running full blast for technical studies; its students even dressed in overalls. Scott may have recalled Leacock's notion when he developed in more detail the dynamics of a university that was vertical. However, architectural reality outdid fiction: Pittsburgh's real life Cathedral of Learning, built from 1926 to 1937, would reach much higher than Leacock's invention-to 42 stories. Moreover, unlike Leacock's students, the Cathedral's students, as imagined by Scott, were closely regulated. Scott produced a dual spoof-architectural and social. From the spark of the soon to be built, vertical skyscraper university in Pittsburgh, he imagined the restricted student life such a building might have spawned six decades in the future.

Scott uses the time honored device of traveling through a time machine (hidden in a cave on Mount Royal) to reach the year 1985. Then he catches an airplane to Pittsburgh. There, he finds the Cathedral tower swarming with students who are attended by helpful but bossy officials. He is told to register and pushing the buttons of a timer clock finds himself issued with a ticket reading: "STUDENT NO. 9999 SUBJECT Pisciculture FLOOR 14 ROOM K5 SEAT 421 DATE Nov. 15 '85 TIME 10.01 A.M. All tickets to be filed before leaving." ${ }^{3} \mathrm{He}$ jumps on one of the many speeding elevators but it is the wrong one; it goes nonstop to the Philosophy floor not to Pisciculture [fish breeding]. A student takes him into a lounge and clues him in about the university:

Let metellyou at once that you are now in the greatest, in fact the only, Cathedral of learning in the world. This lounge is higher above ground than the dome of St. Peter's; there is more stone in this building than in the Great Pyramid; we have a larger number of students than any two Continental Universities; we turn out more graduates in a year than Oxford and Cambridge do in five; we have faster elevators and greater office space than the Woolworth building. In this majestic educational skyscraper there are four miles of corridors, nine dance-halls, 14 gymnasiums and 735 pure Gothic doorways. We manufacture everything used in this building, for whatever purpose, in our own workshops-yes, everything from tobacco to text-books. ${ }^{4}$

Scott's new acquaintance boasts the university teaches every possible subject. Its Research Department constantly develops new studies. Fifty-two different degrees are offered-one for each floor of the building.

Not a moment of the undergraduate's time is wasted. By the card-index system we can account for every minute of his day. If he fails to reach his lecture before the door is locked, he must report within five minutes to the nearest gymnasium for an hour's drill. By our speedy elevators we have reduced to a 
minimum the time required to go from lecture to lecture. Even when his hour of recreation is due, he must obtain a certificate of attendance in the Lounge set apart for students following courses similar to his own so that his conversation may run on lines similar to his work. ${ }^{5}$

The student notes that he will credit his talk with Scott on his (the student's) attendance card as "Propagandism" and takes it to be signed for credit by one of the omnipresent officials. Scott flees, fearing his heart will not take any more strain. Like many dystopias - and indeed like many utopias - there is an atmosphere of enthusiastic but robot-like existence in what is close to being a prison. Scott, like Leacock and Messac, portrays American university education as preoccupied with technology, expanding physical plants, and-most of all-an engrained boosterism, which graduates could apply whether they went on to selling cars or entering the ministry. One wonders if Scott and Messac ever met, from 1924 to 1927, when they were at McGill. Both ridiculed sacred cows, especially the university and its administrators; both continued to rock the boat of authority as they grew older.

\section{ENDNOTES}

${ }^{1}$ F.R. Scott, "The Cathedral of Learning," McGill Daily Literary Supplement, Vol. I, No. 7, 19 November 1924, 1, 4. In a few years, Messac would write his university satire (examined elsewhere in this volume). Apparently, he was not yet interested in the dystopian science fiction at which he would excel in the 1930s. His novel about McGill does not portray the future nor was it likely influenced by Scott's article.

${ }^{2}$ Leon Edel, "The Young Warrier in the Twenties," On F.R. Scott, ed. Sandra Djwa and R. St J. Macdonald, McGill-Queen's University Press, Kingston and Montreal, 1983, 10. See also Sandra Djwa, The Politics of the Imagination: a Life of F.R. Scott, McClelland and Stewart, Toronto 1987, 85.

${ }^{3}$ Scott, "Cathedral," 1.

${ }^{4}$ Scott, "Cathedral," 1, 4.

${ }^{5} \mathrm{~S}$ cott, "Cathedral," 4. The building as originally planned was to have had the 52 stories to which Scott's fictional student refers. Its architect was Charles Z. Klauder (1872-1938), famous archiect of grandiose university buildings. The exterior and interior designs are usually described as gothic. The building has 42 stories and a height of $163 \mathrm{~m}$. The building was partly funded by public donations; school children were asked to give ten cents to "buy a brick." It was the world's tallest building devoted to education until it was surpassed by Moscow University's tower (1949-1953) of 36 stories topped by a spire, $240 \mathrm{~m}$ high. 


\section{Buildings and Construction at McGill, \\ 1970-2002}

\section{by Peter F. McNally}

A lthough McGill's great building spree of the 1960s began leveling off in the early '70s, as it did at other Canadian universities, new construction and renovation of older buildings would characterize the University throughout the final three decades of the $20^{\text {th }}$ century - the principalships of Robert Bell (1970-1979), David Johnston (1979-1994), and Bernard Shapiro (19942002). That the pace of work would be somewhat reduced, reflected how thoroughly McGill's geography had been restructured in the ' 60 s to accommodate future teaching and research activities. The combination of late $20^{\text {th }}$ century inflation and new construction would, however, increase five fold the value of buildings, grounds, and equipment.

Completion of the '60s agenda resulted in notable building being constructed during the 1970s. In 1971, Burnside Hall was opened to house the departments of Geography, Mathematics, Meteorology, Computer Science, and the Computing Centre. That same year, the old Student Union was gutted and rebuilt as the McCord Museum; and the east wing and central block of Royal Victoria College were remodeled and renamed, Strathcona Music Building, after Lord Strathcona-RVC's founder. In 1972, the newly constructed Samuel Bronfman Building began housing the Faculty of Management. Its construction required the controversial demolition of Prince of Wales Terrace, northwest corner of Sherbrooke and McTavish Streets. In 1974, the gymnasium of the former Royal Victoria College, and now Strathcona Music Building, was gutted and reopened as Maurice Pollock Hall. This hall hosts tens of thousands of people annually at musical events, and for many Montrealers is their major point of contact with McGill. A new physics building was inaugurated on University St. in 1977-named after McGill's Nobel Laureate, Lord Rutherford. The concrete brutalist architecture of the Burnside, Bronfman, and Rutherford buildings elicited little contemporary enthusiasm. In 1978, the opening of the Macdonald-Stewart Building at Macdonald College marked the end of prolonged uncertainty about the College's future and the start of a new era for the Faculty of Agriculture. The Wilder Penfield Wing of the Montreal Neurological Institute, also in concrete brutalism, opened in 1979.

Fulfillment of a goal first articulated in 1949 of acquiring the block bound by McTavish and Peel streets to the east and west and Pine Avenue and McGregor St. to the north and south, was achieved in 1976 with McGill's acquisition for $\$ 1.5 \mathrm{M}$ of the Marianopolis College property-when the College moved elsewhere in the city. With this purchase, comprising both heritage and newer buildings, the University's future growth on contiguous property was assured. Existing buildings at the south-west corner of the block were remodeled and re-opened in 1979 as the R. E. Powell Student Services Building-named after the University's tenth Chancellor, 1957-1964. The older buildings have been preserved and used by various units. In 1978, McGregor St. was renamed Avenue du Docteur-Penfield, in honour of the MNI's founder, Wilder Penfield.

Instead of large new construction projects, the 1980s saw major renovation of older building projects, funded in part by the McGill Development Program of the '70s. In 1982, Redpath Hall-opened in 1893 as the library's reading room but used since 1954 for meetings and concerts-was reopened after renovations and the addition of a classical French organ, constructed by Helmuth Wolf. Along with Pollock Hall, Redpath Hall supports the performance stream of the Faculty of Music and welcomes large audiences to McGill. The Macdonald Physics Building-having been radically remodeled and renamed the Macdonald-Stewart Building - was reopened in 1982 as the Physical Sciences and Engineering Library. In 1987, after renovation by Architects Ray Affleck and Arcop Associates, the Macdonald Chemistry Building was renamed the Macdonald-Harrington Building, and became home to the Schools of Architecture and Urban Planning. All three buildings were originally designed in the 1890s by Sir Andrew Taylor, an outstanding Montreal architect responsible for more McGill buildings than anyone else in the University's history.

One of the few new buildings of the decade was the 1984 Webster Pavilion and Brain-Imaging Centre at the Montreal Neurological Institute and Hospital.

The 1990s began with several renovation projects, and the opening of new buildings. In 1990, the McGill bookstore moved into a specifically designed structure on McTavish St. that, at the time, was the largest university bookstore in Eastern Canada. Solin Hall, which had begun life as a chocolate factory near the Atwater Market, was gutted and reopened in 1990 as a student residence. The reopening of Lady Meredith House, at the corner of Peel and Pine, in 1991 after being damaged in a fire the previous year, would be widely acknowledged as a highly successful restoration project. In 1991, the McCord Museum reopened after extensive renovation and the construction of new wing, which doubled its size. Tomlinson Hall and Tomlinson 
Fieldhouse were inaugurated in 1993/94, as part of the student supported project to expand and enhance the Sir Arthur Currie Gymnasium. Dr. Richard Tomlinson's generosity was crucial to the success of this project.

At the end of the decade, McGill embarked upon the design and construction of several new buildings. Great care was taken with their design, due to space constraints within the University's campus, and height restrictions imposed by the city on new construction near Mount Royal. Instead of a uniform style, a range of architects and contemporary designs were employed. One unifying characteristic of these new buildings was their lack of parking facilities. In 1997, the M. $\mathrm{H}$. Wong Engineering Building was opened along the upper stretches on Dr. Penfield. The following year, the Nahum Gelber Law Library opened on Upper Peel St, contiguous with Chancellor Day Hall. Unlike the Wong Building that was financed by both private benefactors and government grants, the Gelber Library was paid for entirely by private money. In 1999, the William and Mary Brown Student Services Building, contiguous with the Student Union, was opened. The Montreal Neurological Institute's Brain Tumour Research Centre was officially opened by Prime Minister Jean Chrétien in 2002.

Towards the end of this era, development of McGill's physical plant took a sharp change of direction. An office building at 688 Sherbrooke St. W., corner of University St., was purchased in 1998 for joint academic and administrative use. On September 12, 2002, McGill bonds were issued to raise funds for a self-financing, student-residential project. The issue proved highly successful, raising $\$ 150 \mathrm{M}$.

*NOTE: TABLES 1, 2, \& 3 "Property Value and Construction in Progress" are based upon information found in the annual financial reports to the Board of Governors.

\begin{tabular}{|l|l|l|}
\hline YEAR & $\begin{array}{l}\text { Estimated Value of Grounds, } \\
\text { Buildings, and Equipment }\end{array}$ & Construction in Progress \\
\hline 1970 & $\$ 123,633,347$ & $\$ 3,782,743$ \\
\hline 1971 & $\$ 135,275,688$ & $\$ 2,795,802$ \\
\hline 1972 & $\$ 138,609,601$ & $\$ 5,376,846$ \\
\hline 1973 & $\$ 142,603,443$ & $\$ 6,499,065$ \\
\hline 1974 & $\$ 145,704,402$ & $\$ 6,722,495$ \\
\hline 1975 & $\$ 155,649,853$ & $\$ 3,031,320$ \\
\hline 1976 & $\$ 158,480,981$ & $\$ 5,056,675$ \\
\hline 1977 & $\$ 168,403,030$ & $\$ 7,695,097$ \\
\hline 1978 & $\$ 177,231,000$ & $\$ 14,773,000$ \\
\hline 1979 & $\$ 199,453,000$ & $\$ 4,204,000$ \\
\hline
\end{tabular}

TABLE 1. Property Value and Construction in Progress* 


\begin{tabular}{|l|l|l|}
\hline YEAR & $\begin{array}{l}\text { Estimated Value of Grounds, } \\
\text { Buildings, and Equipment }\end{array}$ & Construction in Progress \\
\hline 1980 & $\$ 203,353,000$ & $\$ 4,099,000$ \\
\hline 1981 & $209,583,000$ & $3,853,000$ \\
\hline 1982 & $218,735,000$ & $5,236,000$ \\
\hline 1983 & $231,195,000$ & $8,960,000$ \\
\hline 1984 & $237,564,000^{* *}$ & $12,416,000$ \\
\hline 1985 & $(228,665,000)^{* *}$ & $6,575,000$ \\
\hline 1986 & $247,083,000$ & $9,823,000$ \\
\hline 1987 & $262,982,000$ & $9,191,000$ \\
\hline 1988 & $277,594,000$ & $10,301,000$ \\
\hline 1989 & $290,522,000$ & $\begin{array}{l}14,396,000 \# \# \\
(16,097,000) \# \#\end{array}$ \\
\hline
\end{tabular}

TABLE 2. Property Value and Construction in Progress*

**the 1984 and 1985 figures disagree with one another \#\#the 1989 and 1990 figures disagree with one another

\begin{tabular}{|l|l|l|}
\hline YEAR & $\begin{array}{l}\text { Estimated Value of Grounds, } \\
\text { Buildings, and Equipment }\end{array}$ & Construction in Progress \\
\hline 1990 & $\$ 328,536,000$ & $\$ 24,681,000$ \\
\hline 1991 & $381,376,000$ & $14,428,000$ \\
\hline 1992 & $413,805,000$ & $4,847,000$ \\
\hline 1993 & $437,804,00$ & $6,387,000$ \\
\hline 1994 & $491,086,000$ & $10,429,000$ \\
\hline 1995 & $540,755,000$ & $8,018,000$ \\
\hline 1996 & $(532,346,000)^{* *}$ & $20,000,000$ \\
\hline 1997 & $515,898,000^{* *}$ & $6,300,000$ \\
\hline 1998 & $518,764,000$ & $38,690,000$ \\
\hline 1999 & $489,845,000$ & $34,827,000$ \\
\hline 2000 & $499,967,000$ & $13,671,000$ \\
\hline 2001 & $572,584,000$ & $9,741,000$ \\
\hline 2002 & $602,005,000$ & $22,031,000$ \\
\hline
\end{tabular}

TABLE 3. Property Value and Construction in Progress*

** Plant assets were re-evaluated according to methods and rates, varying by asset class, determined by Quebec. This formula was followed thereafter and accounts for the initial decrease in value. 



\section{"Easy, debonair and brisk": Maxime Ingres at McGill, 1895-1900}

\section{by Robert H. Michel}

F rench-born Maxime Ingres, like Régis Messac, taught French language and literature for five years at McGill and left discontented. No social critic, less scholarly than Messac, more dramatic, he personified French culture at McGill from 1895 to 1900 . I chanced across him in a memorandum from McGill Principal William Peterson to University Librarian Charles Gould dated 10 November 1897:

I have only now been able to look at one of the two French books which I had the curiosity to borrow the other day- Aphrodite. It is of such a character that it should at once be removed from the catalogue (unless you are to keep a secret chamber in the Library). And if it was M. Ingres who selected it, I think he must be asked to explain on what principle he would justify his choice.

Aphrodite (1896), by Pierre Louÿs about a Greek courtesan, was one of those erotic novels about lurid, motiveless crimes at which French writers have excelled since de Sade. Its slaves, nudity, crucifixion and porno-historical frosting had made it notorious by the time Peterson found it in McGill's new gothic Redpath Library. Peterson's reaction that it was unsuitable for students was unsurprizing. Ingres, as Messac would in the 1920s, requested the Library to buy numerous French classical and modern works. Among those arriving in October 1897 lurked Aphrodite. Ironically, the books were funded by Lord Strathcona, who had endowed women's education at McGill but demanded that women be taught chastely in separate classes from men. Gould removed Aphrodite; it disappeared; times changed; the book was reordered in 1934.

Ingres and Peterson both arrived at McGill in Fall 1895. Ingres had run a language school in Montreal since 1891 [he seems to have taught in the Maritimes previously] and was around 35 when a McGill Governors' committee hired him at the lecturer rank, for $\$ 1800$ a year, to "take charge of the French Department" for 1895-1896. He succeeded the higher ranked French-born Professor Pierre Darey, who retired after teaching since 1860 . Ingres's subordinate was French-Canadian Protestant Rev. J.L. Morin, who in 1921 would be accused by Professor of German Hermann Walter of poisoning his well. Ingres introduced the conversational Natural Method (popularized by Berlitz since the 1880s), with instruction mainly or totally in French. While at McGill, Ingres published his own Natural Method textbook in
1899: Methode Ingres pour l'enseignement de la langue française (Renouf, Montreal). The introduction (in English) decried the memorizing of grammatical rules: "The organ by which we learn a language is the ear not the eye." Students learned little from traditional methods: "Years are spent in blundering through two or three hundred grammatical rules, as tedious to him who does not know the language as would be a set of directions for the use of a complicated machine of which neither a specimen nor a design was before the eye." $\mathrm{He}$ ridiculed traditional examinations: "They generally come with some crooked, tortured, insipid, treacherous single sentence, spiked with participles and subjunctives, as dangerous to handle as a dynamite bomb, and impossible to get correctly, if one is not familiar with the whole philosophy of the language." In sum: "To speak any language is not a science; it is an art like dancing or simply walking. It cannot be acquired by rules."

Innovative though the Natural Method was, McGill Calendars since 1857 had claimed instruction was exclusively in French. By the 1870s and 1880s, however, this claim was reduced to third and fourth year courses. In the Ingres years, the Calendars for 1896-7, 1897-8, and 1898-9 once more declared all instruction would be exclusively in French and by the "Natural Method." In 1899-1900 this was downgraded slightly to apply only to the second, third, and fourth years. Presumably beginners kept lapsing into English. The course descriptions and examinations in the Calendars, 1895-1900, indicate that Ingres, assisted by Morin, taught the traditional curriculum of grammar and classical French literature but with an increased emphasis on oral examinations, slightly less on verse and more on $19^{\text {th }}$ century prose. Exercises turning classical French passages into modern French were added to traditional dictation and composition. New courses were offered in philology, history of literature, and composition. The examinations resembled earlier ones, although in April 1897 students in some courses wrote in French for one hour of their three hour final on a topic of their choice; they could bring Larousse dictionaries. This seems freer than earlier and later exams.

Beside teaching and ordering books, Ingres proposed a French Club, apparently for both men and women students. The student journal McGill Fortnightly implied in November 1895 that the club was being delayed because the sexes, as in classes, might have to be (probably quoting Ingres) "séparés come des bêtes féroces." Meanwhile, Ingres lobbied the Library for a meeting room. Finally approved by the Governors in 1897, the club promoted practical knowledge of French. Biweekly meetings could include games, conversations, debates, 


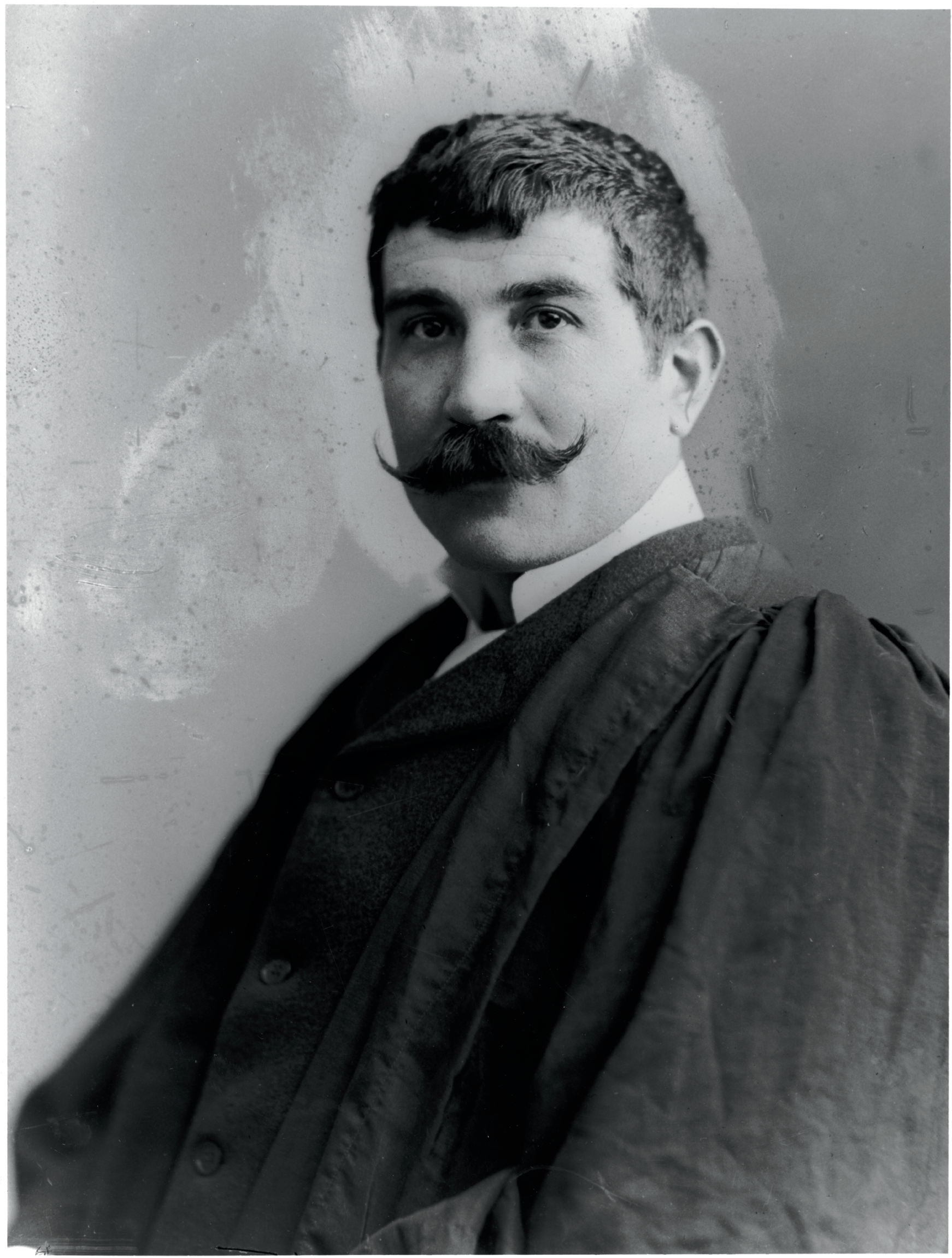

B\&W photograph of Maxime Ingres, 1896 (in academic robe) Notman Photographic Archives Ref. II-114340 
and recitations - all in French on the pain of fines. It may have been co-ed: in late November 1897, the Fortnightly claimed that nineteen (men) had joined and "and enjoy the company of the ladies very much." This club, probably shortlived, anticipated McGill's later Cercle Français.

In the small McGill of about 400 students, Ingres quickly became a campus character. The student journal McGill Fortnightly, and its successor after October 1898 the McGill Outlook, reveled in humorous campus news. They singled out Ingres as a likeable yet acerbic, slightly forbidding teacher who demanded promptness and participation from his students. He would threaten that latecomers would be marked absent; Old McGill 1899 reminded women students of: "Les chocolats et la classe avancée/ Of the Ingres voice of the figure gaunt/ Saying, 'Je vous marquerai absente." One class took revenge in February 1899; they left before a tardy Ingres arrived. Other anecdotes reported a dog (possibly Ingres's) coming into French class, and roughhousing by men students after class. Old McGill 1900, pastiching Canterbury Tales, wrote of one student, Mary Helena Dey (B.A. 1900): "And French she spak full fair and fetysly, After the scole of Ingres at McGill." Annie Holiday (B.A. 1899) wrote her parents: "My appetite [for books] is rapidly increasing. Mr Ingres our professor finds that I am very well up in French \& thinks for that Subject that I should be in the Second Year instead of the first." She won a first class in January 1896 but suspected Ingres forgot to get the exam results published. The Fortnightly referred in 1895 to the "literary effusion" of students of French writing essays [by the Natural Method] "showing our independence of thought by disregarding those rules which we cannot quite remember." In November 1895, women students (taught in separate classes from men) were assigned to write in French letters to their most intimate friend. Ingres made the students have fun while they learned. Occasionally, he offered prizes for recitations. The McGill Outlook reported in February 1899: "Our French Professor's exciting fairy tales are evoking great interest. The attendance at lectures is increasing." A member of Montreal's Pen and Pencil Club, Ingres wrote verse and short stories; perhaps he read these to his class. His spooky story "Le Dolmen" appeared in the Fortnightly in January 1898. $\mathrm{He}$ also wrote a McGill drinking song, a story about the woes of a black francophone in Halifax, and a starvation story set during the Franco-Prussion War. Ingres was fiercely revanchist, as the Fortnightly reported in December 1895:

Student.- "Je voudrais être médecin chez les Allemands."

French Professor. - "Il vous faut étudier la science vétérinaire."

From 1891 to 1900 Ingres ran the Ingres-Coutellier School of Modern Languages, housed at the Fraser Institute (with branches in several Canadian cities). Fellow tenants included the portraitist Alphonse Jongers, close friend (and perhaps related) to Ingres. The Institute's records show Ingres being dunned frequently for rent, using the shared telephone too much, and having an employee who climbed into the Institute through a window while the building was shut for Dominion Day. One of Ingres's private students was Amy Redpath (later Roddick), future donor of McGill's Roddick Gates. French lessons gave this wealthy single woman of 29 an intellectual and creative outlet. Simultaneously she learned German from a Mrs. Gebhardt and ran her family's large house for her brothers and widowed mother. Her diary, mainly in 1897, often refers to writing essays and studying for Ingres on historical and literary subjects, including: La Chanson de Roland; translating Ibsen's Doll House; de Vigny's poems; French medieval history; an essay on the recently performed play Rudens at McGill; and a fable by Napoleon. She also "learnt one of Mme Ingre's [sic] letters, one of those affectionate outbursts to her daughter [Ingres was married]. Have now wended through the dawn \& middle ages of French literature \& stand upon the threshold of the renaissance." Fascinated by her studies, she wrote a rondel and "tried my hand ballad writing with refrain sur les epaules de mont royale" [she later published poetry], studied Montaigne on education, and read Corneille and Moliere. Ingres showed her his portrait by Jongers in the studio next door.

After two successful years, things began to go wrong. While Ingres had been hired "to take charge" of French for 18951896 and was rehired on the same terms again for 18961897, by late November 1897 the Governors and Peterson were making it clear that Ingres would not be promoted to professor nor receive increased salary. This was in spite of Ingres's initiative that November of offering a special course of fifteen lectures to local French teachers. (In 1900 he would propose French summer courses, anticipating McGill's famous French Summer School). Peterson may have blamed Ingres for ordering Aphrodite but far more important he saw little place for Ingres in the stronger more scholarly Department of Modern Languages he was planning, which would unite the two lecturers in French with the two in German. Although he never criticized Ingres's teaching or methods, by 1899, Peterson was whittling down Ingres's hours and status. Ingres had only a bachelor's degree (from Paris); since Ingres arrived, the chief German lecturer, Leigh Gregor, had earned a Ph.D. from Heidelberg (1896) and been given a vote in the Faculty of Arts (March 1897) unlike Ingres. Around 1899 Peterson made Gregor in effect acting head of the new Modern Languages Department. Gregor received a bonus for reorganizing the Modern Language courses for 1899-1900. Bitterly, Ingres described his rival as better fit to serve behind a counter than run a department. [Yet perhaps Gregor actually fitted in better socially: he even had McGill's women students invited to see the art collections of Montreal millionaires.] Under Peterson McGill, like many universities, emulated the German model and aimed to hire staff with doctorates and scholarly publications. 
Mid-May 1900, Ingres wrote Peterson from University of Chicago [a clue he was job hunting!] declaring he made only $\$ 500$ in his private teaching and most of his time went to McGill. [Perhaps Peterson looked down on Ingres and his school as too entrepreneurial and un-academic.] Ingres also suggested French and German revert to separate departments; his own ambitions aside, as an anti-German Frenchman he had no sympathy with the recent amalgamation. They corresponded in English, which Ingres wrote nearly flawlessly. Peterson, always careful in what he wrote, could point out he had never promised Ingres advancement. He declared that Ingres simply did not have the training to be head of French. He also may have feared Ingres was too feisty, too self-promoting to administer tactfully. Ingres's letters to Peterson were polite but increasingly reproachful, declaring himself disappointed, deceived and under-valued; Peterson's were appreciative of past service but unyielding. He offered part-time teaching. Demanding to the end, Ingres declared he would resign unless he was given the status and salary of a professor. In late May 1900 he indeed resigned, boasting Chicago had hired him for more than any McGill Arts professor was paid. Peterson rushed to find a short term replacement, Dr. Jacob B. Segall, for 1900-1901, while he decided how to configure Modern Languages. The changes of 1899 to1901 would be echoed in reverse by the breakup of Modern Languages into Romance and Germanic Languages 20 years later, after the Morin-Walter poisoning episode. In 1901 Peterson stated his objective in the McGill University Magazine: "surely McGill ought to become one of the most notable centres on the whole continent of the study of French!" In the event, it would not be Gregor but a new man, another Ph.D., Hermann Walter, who became chief after 1901.

Ingres taught the Natural Method at Chicago, 1900 to ca. 1906. Involved in many university and civic matters, he became a director of the prestigious Alliance Française, which had close teaching ties with Chicago. He became "officier d'Académie," a French government honour for educationalists. Later he may have moved to Buenos Aires. In 1931 McGill's Colonel Wilfrid
Bovey, reported that Ingres had died in Paris of a heart attack, aged about 70, and described him as "a staunch adherent and follower of Paul Déroulède, the patriot who urged that France take some revenge on Germany for the havoc played by the latter on the French people during the War of 1870. Professor Ingres was very violent on this subject... and never missed the opportunity of expressing his point of view on this matter. He was also a fencer of note and participated in many parries with other fine wielders of the rapier...." From his 1896 Notman photograph as a confident new McGill professor in academic gown, one might easily guess Ingres fenced, smouldered over Prussia's defeat of France-and wrote poetry and stories as well.

Ingres liked the students; he ordered books and founded a French Club for them. He wrote them a poem in Old McGill 1899, Si Jeuness Savait, beginning and ending with: "Qu'il est doux d'avoir l'age où l'on croit tout savoir" and regretting the loss of "Le bonheur des vingt ans qui ne peut revenir." And the students liked him: when Old McGill 1901 gave professors captions, his was "- The Frenchman, easy, debonair and brisk."

\section{SOURCES}

McGill University Archives: RG2, Principals' records, incoming (alphabetical) and outgoing (chronological) correspondence, 1895-1900; RG4, Board of Governors, Minute Books, 1895-1900; RG40, McGill Library records, alphabetical files, 1895-1900; University Scrapbooks of newsclippings, 1895-1900, 1931 (Montreal Gazette, obit., 8 Jan. 1931); Annie Holiday Fonds, MG 4222. McGill Library Rare Books and Special Collections: Library Accessions Register, Acc. 62,863, 7 Oct. 1897: Aphrodite (reordered in 1934, Acc. 290,564); Amy Redpath Fonds, MS 659. McCord Museum Archives: Pen and Pencil Club. Fraser-Hickson Institute: correspondence, 1890s. University of Chicago, Presidents' Papers, 19011906. Publications: Maxime Ingres, Méthode Ingres (Renouf, Montreal, 1899, xviii-xx; $2^{\text {nd }}$ ed. Chicago, 1901), McGill University Calendars, 1894-1895 to 1900-01; Old McGill, 1898-1901; McGill Fortnightly, 1895-1898; McGill Outlook, 1898-1900; McGill University Magazine, 1 Dec. 1901. Thanks are due the staffs of McGill University Archives; McGill Rare Books and Special Collections; Cyndie Campbell, Archivist, National Gallery of Canada; Fernando Montserrat, Fraser-Hickson Library; and Jessica Westphal, Robin Anne O'Sullivan, University of Chicago Library. 


\section{Contributors}

GORDON BURR is Senior Archivist, Collections Management and Digital Services in the McGill Archives. He is a twotime McGill graduate with a BA in history and a Master's degree in Library and Information Studies. As an associate member of the McGill's Graduate School of Library and Information Studies, he teaches courses on archival subjects. He was the Executive Secretary of MUNASA from 2006 to 2010.

WILLIAM FONG was born in Montreal and has obtained his BA and LLB degrees from McGill, and his MA and PhD in history from the University of Toronto. He has his MBA degree from York University in Toronto and a Postgraduate Diploma in Chinese law from the University of Hong Kong. Formerly a practising lawyer, he has published two McGill-related biographies, Sir William Macdonald (2007) and J.W. McConnell (2008), both through McGill-Queen's University Press. Currently, he is working on two other books.

DANIEL HICKEY is Emeritus professor, Département d'Histoire et géographie, Université de Moncton. He is the author of Local Hospitals in Ancien Régime France: Rationalization, Resistance and Renewal. Montréal-Kingston: McGill University Press, 1997 and more recently has collaborated in a collective work, Chabot, Hickey and Pâquet, Autour de la médicalization: perspectives historiques, partiques et représentations (XVe-XXe siècles). Québec: les presses de l'Université Laval, 2012.

A.J. HOBBINS is an Emeritus Librarian, following a career of over forty years in the McGill Library system. His most recent positions were Associate Director of Libraries and Law Librarian. His recent research has been principally in the area of the history of the international law of human rights and the history of legal education in Canada. This article is an offshoot of his researches into the McGill Faculty of Law.

SVETLANA KOCHKINA received her MLIS from the McGill University School of Information Studies in 2010 and became a PhD student at the McGill SIS in 2013. Her main research interests include the History of Books and Printing and the History of Private Libraries and Collections. She began working on reconstruction of the Mussen collection while she was a student at the McGill SIS. She has been employed as a liaison librarian at McGill University Law Library, Montreal, QC, Canada since 2010.

PETER F. MCNALLY is a Professor in McGill University's School of Information Studies, in addition to being Director of the History of McGill Project and author of the forthcoming Vol. III (1970-2002) McGill University: for the Advancement of Learning. He has published extensively on the history of books, printing, and libraries, as well as on the history of McGill, in a variety of publications, including Fontanus.

ROBERT H. MICHEL holds a doctorate in history from McGill University and was archivist for historical records and reference services at the McGill University Archives from 1974 to 1995. He has contributed to Fontanus with articles on diaries in McGill's archives, the military portraits of Sir Arthur Currie, a 17th-century English religious romance, satires involving McGill, Sir William Macdonald (with Stanley B. Frost), and Dr. Harold Trott's student memoirs. His Fontanus articles on writers Dink Carroll, Norman Levine, and Régis Messac have focused on how they used their McGill experiences to develop novels.

SEAN SWANICK is the Islamic Studies Liaison Librarian at McGill University. He holds a MA in Middle East Studies from the University of Exeter, England (2007) and a MLIS from Dalhousie University (2009) in Halifax, Canada.

MACY ZHENG holds a Bachelor's degree in English from Remin University (Beijing), a Master's degree in East Asian Studies (Columbus, Ohio), and a Master's degree in Library and Information Science (Toronto). She began working at the McGill Library as a cataloguing librarian in 2001, and is currently an Associate Librarian for East Asian Studies. She has published articles on the education of Canadian librarians, on the new model of liaison services at academic libraries in North America, and on McGill's digitization project of Ming Qing women's writings. She has also published a Chinese translation of an article by Pat Riva on the Functional Requirements for Bibliographic Records (FRBR). 


\section{Guidelines for Authors}

Aiming at annual publication, Fontanus is devoted to scholarly research based principally upon McGill University collections. The term "collections" is interpreted in the broadest sense, to include library, archives, specimens, artifacts, buildings and other forms of documentary evidence. Contributions derived from all aspects of McGill collections will be considered. Contributions may be submitted in English or French. Submission of a contribution is normally understood to imply that it has not been previously published and that it is not under editorial consideration elsewhere. All submissions will be reviewed by the Editors and refereed by experts in the appropriate field. Under our Notes and Comments section, we also welcome short, informal submissions generally under 3,000 words based on McGill collections or items within them. Any substantial changes will be cleared with the author before publication. Send submissions, prepared according to the instructions below, by email to fontanus. library@mcgill.ca.

\section{FORM OF MANUSCRIPT}

All manuscripts must be submitted electronically in .rtf or .doc format. Notes should be numbered consecutively and follow the text of the article. The name of the author(s) should appear after the title and before the text of the article. A short biographical note of no more than 200 words should be included separately. Degrees, current and previous positions and major publications among other things may be noted.

\section{ABSTRACTS}

A brief abstract (which must not exceed 200 words) of the content of the article should be prepared by the author.

\section{FORM OF CITATION}

Manuscripts should normally conform to the standards outlined in The Chicago Manual of Style (Chicago: University of Chicago Press, 2010). Translations of passages in languages other than French or English should be provided in the text.

\section{ILLUSTRATIONS}

Photocopies or electronic format of visual material (with brief captions) must be submitted by authors for initial evaluation. Once an article has been accepted, the author is responsible for supplying clear glossy photos or high resolution graphic files, preferably (300 dpi TIFF images) of the illustrations, and for securing the permission to publish copyrighted material if necessary.

\section{AUTHOR RIGHTS}

Starting with this Volume XIII (2013), all authors will publish under a Creative Commons Attribution-NonCommercialNoDerivs 3.0 license under which authors retain copyright after initial publication in Fontanus. For more information about Creative Commons, visit www.creativecommons.org. 


\section{Fontanus Publications}

\section{FONTANUS Journal Series}

http://fontanus.mcgill.ca/

vol. I 1988

vol. II 1989

vol. III 1990

vol. IV 1991

vol. V 1992 Montreal $350^{\text {th }}$ Anniversary Issue

vol. VI 1993 Redpath Issue

vol. VII 1994 Stephen Leacock Issue

vol. VIII 1995 Women in the University Issue

vol. IX $1996 \mathrm{McGill} 175^{\text {th }}$ Anniversary Issue

vol. X 1998 Rutherford Centenary Issue

vol. XI 2003

vol. XII 2010

vol. XIII 2013

\section{FONTANUS MONOGRAPH SERIES}

Adam Gacek, Arabic Manuscripts in the Libraries of McGill University, Union Catalogue, 1991

Calvin Evans, Soren Kierkegaard Bibliographies: Remnants 1944-1980 and Multi-Media, 1925-1991, 1993

Barbara Lawson, Collected Curios: Missionary Tales from the South Seas, 1994

A.J. Hobbins, On the Edge of Greatness: The Diaries of John Humphrey, First Director of the United Nations Division of Human Rights, Vol. 1 , 1948-1949, 1994

Max Dunbar, Essays from a Life: Scotland, Canada, Greenland, Denmark, 1995

Alberto Perez-Gomez and Louise Pelletier, Anamorphosis: An Annotated Bibliography with Special Reference to Architectural Representation, 1995

Adam Gacek, Arabic Lithographed Books in the Islamic Studies Library, McGill University, Descriptive Catalogue, 1996

Irena Zantovska Murray, Sources in Iconography in the Blackader-Lautennan Library of Architecture and Art, McGill University, An Annotated Bibliography, 1995

A.J. Hobbins, On the Edge of Greatness: The Diaries of John Humphrey, First Director of the United Nations Division of Human Rights, Vol. 2, 1950-1951, 1996

Joan C. Bevan and Maria A. Pacelli, The Quintessential Canadian Anaesthetist: Wesley Bourne. A Retrospective on the Foundation of McGill Anesthesia, 1996

Goldie Sigal, A Garment Worker's Legacy: The Joe Fishstein Collection of Yiddish Poetry, 1998

A.J. Hobbins, On the Edge of Greatness: The Diaries of John Humphrey, First Director of the United Nations Division of Human Rights, Vol. 3 , 1952-1957, 1998

A.J. Hobbins, On the Edge of Greatness: The Diaries of John Humphrey, First Director of the United Nations Division of Human Rights, Vol. 4 , $1958-1966,2000$

Stanley Brice Frost, Autumn Harvest: Selected Poems, 2002

Marilyn Silverman, ed., Ethnography and Development: The Work of Richard F. Salisbury, 2004

Martin Entin, Edward Archibald: Surgeon of the Royal Vic, 2004

Adam Gacek, Persian Manuscripts in the Libraries of McGill University: Brief Union Catalogue, 2005

To order from the monograph series:

McGill Queen's University Press

Attn: Martketing Dept

1010 Sherbrooke Street West, Suite 1720

Montreal, QC H3A 2R7

(514) 398-2914

www.mqup.ca 


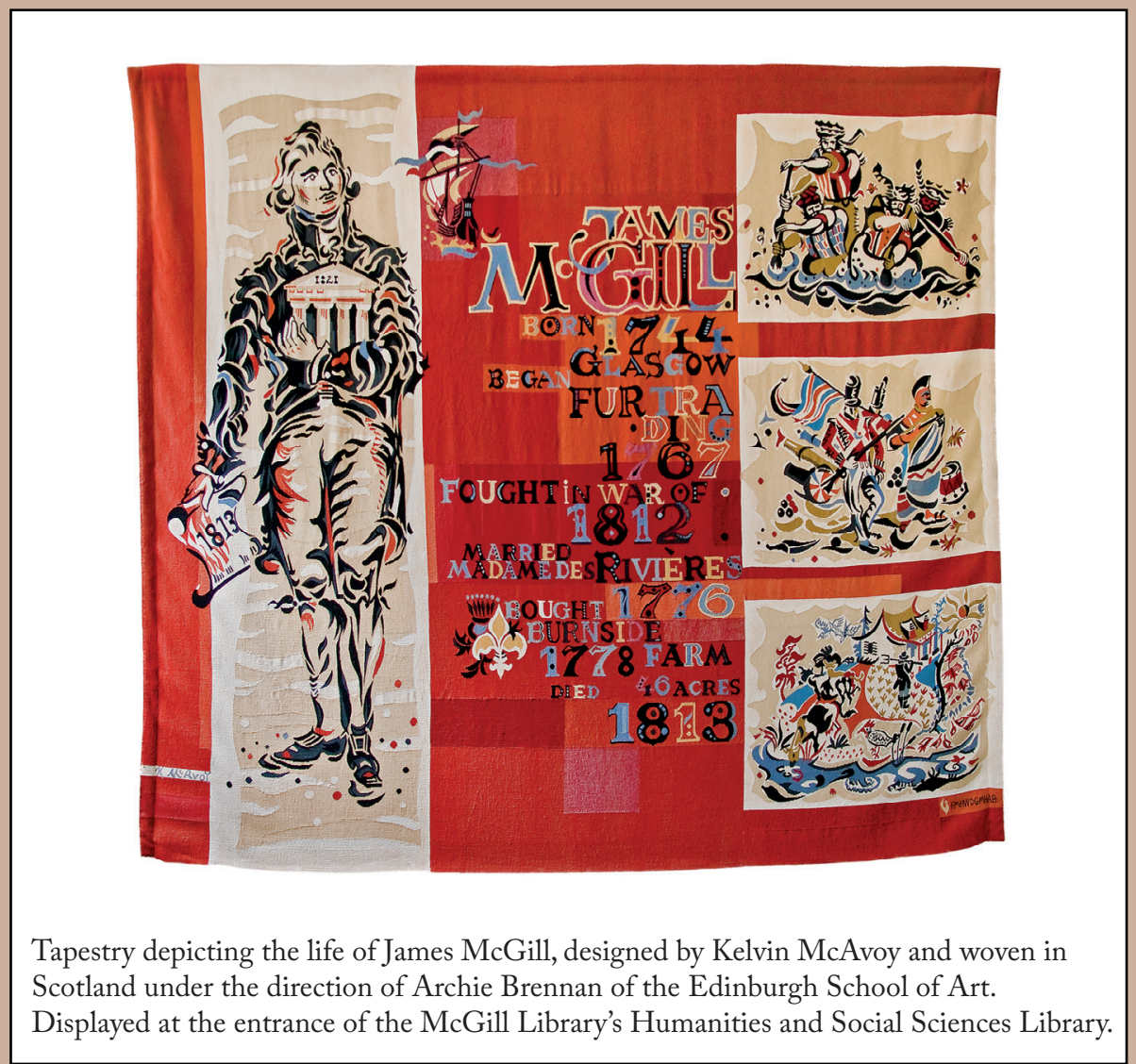

Displayed at the entrance of the McGill Library's Humanities and Social Sciences Library.

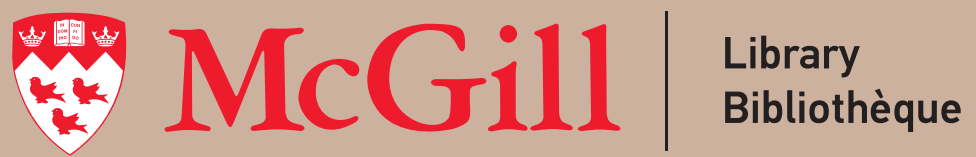

